\title{
Article
}

Mycosphere

\section{Mycosphere notes 51-101. Revision of genera in Perisporiopsidaceae and Pseudoperisporiaceae and other Ascomycota genera incertae sedis}

\author{
Boonmee $\mathbf{S}^{1}$, Phookamsak $\mathbf{R}^{1,2,3,4,5}$, Hongsanan $\mathbf{S}^{1}$, Doilom $\mathbf{M}^{1}$, Mapook $\mathbf{A}^{1}$, \\ McKenzie EHC ${ }^{6}$, Bhat $\mathrm{DJ}^{7,8}$ and Hyde $\mathrm{KD}^{1 *}$
}

\author{
${ }^{\text {I} C e n t e r ~ o f ~ E x c e l l e n c e ~ i n ~ F u n g a l ~ R e s e a r c h, ~ M a e ~ F a h ~ L u a n g ~ U n i v e r s i t y, ~} 333$ Moo 1, Thasud, Muang, Chiang Rai 57100, \\ Thailand \\ ${ }^{2}$ Key Laboratory for Plant Biodiversity and Biogeography of East Asia (KLPB), Kunming Institute of Botany, Chinese \\ Academy of Science, Kunming 650201, Yunnan China \\ ${ }^{3}$ World Agro Forestry Centre, East and Central Asia, 132 Lanhei Road, Kunming 650201, Yunnan China \\ ${ }^{4}$ Department of Biology, Faculty of Science, Chiang Mai University, Chiang Mai, 50200, Thailand \\ ${ }^{5}$ Center of Excellence in Bioresources for Agriculture, Industry and Medicine, Faculty of Science, Chiang Mai \\ University, Chiang Mai, 50200, Thailand \\ ${ }^{6}$ Landcare Research Manaaki Whenua, Private Bag 92170, Auckland, New Zealand \\ ${ }^{7}$ Formerly, Department of Botany, Goa University, Goa, India \\ ${ }^{8}$ No. 128/1-J, Azad Housing Society, Curca, Goa Velha-403108, India
}

Boonmee S, Phookamsak R, Hongsanan S, Doilom M, Mapook A, McKenzie EHC, Bhat DJ, Hyde KD 2017 - Mycosphere notes 51-101. Revision of genera in Perisporiopsidaceae and Pseudoperisporiaceae and other Ascomycota genera incertae sedis. Mycosphere 8(10), 1695-1801, Doi 10.5943/mycosphere/8/10/6

\begin{abstract}
This is the second in a series, Mycosphere notes, wherein we provide notes on various fungal genera. In this set of notes we deal with genera of the families Perisporiopsidaceae and Pseudoperisporiaceae. These families have traditionally accommodated taxa associated with dead and living leaves of mostly tropical plants and comprised pathogens, saprobes or epiphytes. Most genera are poorly understood with only brief Latin descriptions, but molecular sequence data are needed to establish their taxonomic placements. In this study, 50 genera and 51 taxa are reexamined and their placements at the family level discussed. Thirteen new families Alinaceae, Balladynaceae, Cleistosphaeraceae, Dysrhynchisceae, Hyalomeliolinaceae, Lizoniaceae, Nematotheciaceae, Neoparodiaceae, Phaeodimeriellaceae, Pododimeriaceae, Polyclypeolinaceae, Stomatogeneceae and Toroaceae are introduced and Dimeriaceae is reinstated in this paper. One new species, Phaeostigme alchorneae is introduced. Nine genera are transferred to other families. However, fresh collections, epitypification or reference specimens including DNA sequence data, are required to confirm their phylogenetic placements.
\end{abstract}

Key words - Alinaceae - Balladynaceae - Botryosphaeriaceae - Cleistosphaeraceae Coccoideaceae - Dimeriaceae - Dysrhynchisceae - Epibryaceae - Hyalomeliolinaceae Lizoniaceae - Massarinaceae - Mycosphaerellaceae - Myriangiaceae - Nematotheciaceae Neoparodiaceae - Opegraphaceae - Parmulariaceae - Phaeodimeriellaceae - Phaeosphaeriaceae Pododimeriaceae - Polyclypeolinaceae - Schizothyriaceae - Stomatogeneceae Teratosphaeriaceae - Toroaceae - Venturiaceae 


\section{Table of Contents}

2017).

The numbers of taxa in this study are continuation from a previous paper (Thambugala et al.

Dothideomycetes O.E. Erikss. \& Winka

Alinaceae Boonmee \& K.D. Hyde, fam. nov.

51. Alina jasmini Racib., Bull. int. Acad. Sci. Lett. Cracovie, Cl. sci. math. nat. Sér. B, sci. nat. 3: 375 (1909)

Balladynaceae Boonmee \& K.D. Hyde, fam. nov.

52. Balladyna gardeniae Racib., Parasit. Alg. Pilze Java's (Jakarta) 2: 6 (1900)

53. Balladynocallia glabra (Hansf.) Bat., Atas Inst. Micol. Univ. Recife 2: 216 (1965)

54. Balladynopsis philippinensis Syd. \& P. Syd., Annls mycol. 15(6): 476 (1918) [1917]

Botryosphaeriaceae Theiss. \& Syd.

55. Pilgeriella perisporioides Henn., Hedwigia 39(Beibl.): (137) (1900)

56. Myxophora amerospora Döbbeler \& Poelt, Mitt. bot. St Samml., Münch. 14: 315 (1978)

Cleistosphaeraceae Boonmee \& K.D. Hyde, fam. nov.

57. Cleistosphaera macrostegia Syd. \& P. Syd. [as 'macrostegiae'] Annls mycol. (1916)

Coccoideaceae P. Henn. ex Sacc. \& D. Sacc.

58. Coccoidella scutula (Berk. \& M.A. Curtis) Höhn., Sber. Akad. Wiss. Wien, Math.naturw. Kl., Abt. 1 118: 847 [35 repr.] (1909)

Dimeriaceae E. Müll. \& Arx ex Arx \& E. Müll.

59. Dimerium olivaceum Syd. \& P. Syd., Annls mycol. 2(2): 169 (1904)

Dysrhynchisceae Boonmee \& K.D. Hyde, fam. nov.

60. Dysrhynchis pulchella (Sacc.) Clem., Gen. fung., Edn 2 (Minneapolis): 253 (1931)

Hyalomeliolinaceae Boonmee \& K.D. Hyde, fam. nov.

61. Hyalomeliolina guianensis F. Stevens, Illinois Biol. Monogr. (Urbana) 8(no. 3): 27 (1924) [1923]

Lizoniaceae Boonmee \& K.D. Hyde, fam. nov. (1863)

62. Lizonia empirigonia (Ces. \& De Not.) De Not. [as 'Lizonia emperigonia'], Sfer. Ital.: 72

Massarinaceae Munk

63. Semifissispora fusiformis H.J. Swart, Trans. Br. mycol. Soc. 78(2): 259 (1982)

Mycosphaerellaceae Lindau

64. Episphaerella manihotis (Henn.) Petr., Annls mycol. 22(1/2): 126 (1924)

Myriangiaceae Nyl.

65. Uleomyces parasiticus Henn., Hedwigia 34: 107 (1895)

Nematotheciaceae Boonmee \& K.D. Hyde, fam. nov. 66. Nematothecium vinosum Syd. \& P. Syd., Leafl. of Philipp. Bot. 5(76): 1534 (1912) 
67. Nematostigma obducens Syd. \& P. Syd., Annls mycol. 11(3): 262 (1913)

68. Ophioparodia pulchra Petr. \& Cif. Annls mycol. 30(3/4): 223 (1932)

Neoparodiaceae Boonmee \& K.D. Hyde, fam. nov.

69. Neoparodia ekmanii Petr. \& Cif., Annls mycol. 30(3/4): 219 (1932)

Opegraphaceae Körb. ex Stizenb.

70. Opegrapha reactiva (Alstrup \& D. Hawksw.) Etayo \& Diederich (2008)

Parmulariaceae E. Müll. \& Arx ex M.E. Barr

71. Inocyclus psychotriae (Syd. \& P. Syd.) Theiss. \& Syd., Annls mycol. 13(3/4): 211 (1915)

Perisporiopsidaceae E. Müll. \& Arx ex R. Kirschner \& T.A. Hofm.

72. Parodiellina manaosensis (Henn.) G. Arnaud, Annals d'École National d'Agric. de

Montpellier, Série 2 16(1-4): 21 (1918) [1917]

73. Perisporiopsis struthanthi Henn., Hedwigia 43: 83 (1904)

74. Chevalieropsis ctenotricha (Pat. \& Har.) G. Arnaud, Annls Épiphyt. 9: 2 (1923)

Phaeodimeriellaceae Boonmee, Mapook \& K.D. Hyde, fam. nov.

75. Phaeodimeriella parvula (Cooke) Hansf., Mycol. Pap. 15: 64 (1946)

Phaeosphaeriaceae M.E. Barr

76. Aphanostigme solani Syd., Annls mycol. 24(5/6): 368 (1926)

Pododimeriaceae Boonmee \& K.D. Hyde, fam. nov.

77. Pododimeria gallica E. Müll., Sydowia 12(1-6): 195 (1959) [1958]

78. Chaetoscutula juniperi E. Müll., Sydowia 12(1-6): 191 (1959) [1958]

Polyclypeolinaceae Boonmee \& K.D. Hyde, fam. nov.

79. Polyclypeolina brideliae (Hansf.) Bat., Publicações Inst. Micol. Recife 56: 457 (1959)

Pseudoperisporiaceae Toro

80. Eudimeriolum elegans Speg., Anal. Mus. nac. Hist. nat. B. Aires 23: 36 (1912)

81. Lasiostemma melioloides (Berk. \& Ravenel) Theiss., Syd. \& P. Syd., in Sydow \&

Sydow, Annls mycol. 15(3/4): 218 (1917)

82. Nematostoma artemisiae Syd. \& P. Syd., Annls mycol. 12(2): 161 (1914)

Schizothyriaceae Höhn. ex Trotter, Sacc., D. Sacc. \& Traverso

83. Schizothyrium pomi (Mont. \& Fr.) Arx, Proc. K. Ned. Akad. Wet., Ser. C, Biol. Med.

Sci. 62: 336 (1959)

Stomatogeneceae Boonmee \& K.D. Hyde, fam. nov.

84. Stomatogene agaves (Ellis \& Everh.) Theiss., Annls mycol. 14(6): 406 (1918) [1917]

85. Stomatogene yuccae Hansf., Sydowia 11(1-6): 68 (1958) [1957]

Teratosphaeriaceae Crous \& U. Brau

86. Placocrea pulchella Syd., Annls mycol. 37(4/5): 380 (1939)

Toroaceae Boonmee \& K.D. Hyde, fam. nov.

87. Toroa dimerosporioides (Speg.) Syd. [as 'dimerosporoides'], J. Dept. Agric. Porto Rico 2:

$20(1926)$ 
Venturiaceae E. Müll. \& Arx ex M.E. Barr

88. Dimeriella hirtula Speg. Revta Mus. La Plata 15(2): 12 (1908)

89. Neocoleroa sibirica Petr., Hedwigia 74: 38 (1934)

\section{Dothideomycetes genera, incertae sedis}

90. Eumela chiococcae Syd., Annls mycol. 23(3/6): 335 (1925)

91. Leptomeliola hyalospora (Lév.) Höhn., Sber. Akad. Wiss. Wien, Math.-naturw. K1., Abt. 1 128: 558 (1919)

92. Leveillina arduinae (Kalchbr. \& Cooke) Theiss. \& Syd., Annls mycol. 13(3/4): 286 (1915)

93. Phaeostigme alchorneae Boonmee \& K.D. Hyde, sp. nov.

94. Phaeostigme picea (Berk. \& M.A. Curtis) Syd. \& P. Syd., Annls mycol. 15(3/4): 200 (1917) [1917]

95. Scolionema palmarum (Kunze \& Fr.) Theiss. \& Syd., Annls mycol. 15(6): 410 (1918)

Pleoporales genera, incertae sedis

96. Stuartella formosa Fabre, Annls Sci. Nat., Bot., sér. 6 9: 95 (1879) [1878]

Eurotiomycetes O.E. Erikss. \& Winka

Epibryaceae S. Stenroos \& Gueidan (Chaetothyriales)

97. Epibryon plagiochilae (Gonz. Frag.) Döbbeler, Mitt. bot. StSamml., Münch. 14: 293 (1978)

\section{Chaetothyriales genera, incertae sedis}

98. Pleostigma jungermannicola (C. Massal.) Kirschst., Annls mycol. 37(1/2): 91 (1939)

\section{Excluded genera}

\section{Sordariomycetes genera, incertae sedis}

99. Phragmeriella ireninae Hansf. Mycol. Pap. 15: 89 (1946)

\section{Doubtful genera}

100. Keratosphaera batistae H.B.P. Upadhyay, Publicações, Instituto de Micologia da Universidade do Recife \& Instituto Nacional de Pesquis 402: 6 (1964)

101. Raciborskiomyces longisetosus (Volkart) M.E. Barr, Mycotaxon 64: 165 (1997)

\section{Introduction}

This paper is a continuation of a series, which provides notes on new species, new records and poorly known taxa. Re-examination, description, illustration and notes on species, genera and families are provided. The paper mainly deals with genera of Perisporiopsidaceae and Pseudoperisporiaceae, which previously included numerous taxa of foliar epiphytes or pathogens from the surface of the living leaves, as well as saprobes on dead leaves (Toro 1952, Barr 1997, Hyde et al. 2013). Most taxa are found on dicotyledonous leaves and some on ferns, monocotyledonous leaves, gymnosperms or angiosperms, branches and wood in various tropical areas. Most genera and species are devoid of clear understanding of morphological characters and molecular data to indicate their placement (Lumbsch \& Huhndorf 2010, Hyde et al. 2013). This series of Mycosphere notes contains descriptions, illustrations and notes on 51 taxa.

\section{Materials \& Methods}


Holotype and other specimens of taxa were obtained on loan from the collections of Kew Royal Botanic Gardens (K \& IMI), Botanischer Garten und Botanisches Museum Berlin-Dahlem (B), Universidad de Buenos Aires (BAFC / LPS), US National Fungus Collections (BPI), Orange Agricultural Institute (DAR), Farlow Reference Library and Herbarium of Cryptogamic Botany in Harvard University (FH), Karl-Franzens-Universität Graz (GZU), University of Illinois (ILL), University of Michigan (MICH), New York Botanical Garden (NY), Università degli Studi di Padova (PAD), Muséum National d'Histoire Naturelle (PC), Swedish Museum of Natural History (S), Naturhistorisches Museum Wien (W) and University of Zurich (Z). Morphological features were examined and photomicrographs made using a Nikon ECLIPSE 80i compound microscope fitted with a Canon 450D digital camera and measurements made using Tarosoft (R) Image Frame Workprogram. Figures were processed with an Adobe Photoshop CS3 Extended version 10.0 (Adobe Systems Inc., USA). Faces of fungi numbers and Index Fungorum numbers were obtained as detailed in Jayasiri et al. (2015) and Index Fungorum (2017).

\section{Results}

\section{Dothideomycetes}

For the classification of Dothideomycetes we follow Hyde et al. (2013), Ariyawansa et al. (2014), Wijayawardene et al. (2014) and updates in Liu et al. (2017)

Alinaceae Boonmee \& K.D. Hyde, fam. nov.

Index Fungorum number: IF553826; Facesoffungi number: FoF03661

Parasitic or epiphytic on living leaves. Sexual morph: Ascomata superficial, seated on hyphae, globose to subglobose, brown, covered by brown hyphae, with peridium composed of brown cells of textura angularis, lacking pseudoparaphyses. Asci 8-spored, bitunicate, subglobose to clavate, sessile, thick-walled. Ascospores ovoid to obovoid, apex wider, narrower towards the lower and rounded end, brown. Asexual morph: hyphomycetous, Septoidium sp., Shivomyces sp.

Family type - Alina Racib.

Notes - The family Alinaceae is introduced to accommodate the monotypic genus Alina, which was found on living leaves of Jasminum sp. in Indonesia. Morphologically, Alinaceae species are characterised by superficial ascomata, seated on a subiculum of hyphae, lack of pseudoparaphyses, subglobose to clavate asci and ovoid to obovoid, 1-septate, brown, smoothwalled ascospores, features that distinguish Alina from other generic types in Perisporiopsidaceae. In this study, we introduce the new family Alinaceae, because it has a suite of characters that differ from other families of Dothideomycetes.

Alina Racib., Bull. int. Acad. Sci. Lett. Cracovie, Cl. sci. math. nat. Sér. B, sci. nat. 3: 375 (1909)

Parasitic or epiphytic on the surface of living leaves of Jasminum sp. Sexual morph: Ascomata superficial, seated on hyphae, globose to subglobose, brown, covered by brown hyphae, peridium composed of brown cells of textura angularis, lacking pseudoparaphyses. Asci 8-spored, bitunicate, subglobose to clavate, sessile, thick-walled. Ascospores ovoid to obovoid, apex wider, narrower towards the lower and rounded ends, 1-septate, slightly above the center, slightly brown. Asexual morph: hyphomycetous, Septoidium sp., Shivomyces sp. (Sivanesan 1981, Kirk et al. 2008, Seifert et al. 2011).

Type species - Alina jasmini Racib.

Notes - Alina jasmini was found on living leaves of Jasminum sp. in Indonesia and is characterised by superficial mycelium with hyphopodia-like structures, and relatively small ascomata formed on hyphae, containing 1 to 2 asci (Raciborski 1909). Sivanesan (1981) reexamined and described $A$. jasmini specimens from IMI (IMI 214481 = ex isotype and IMI $89544=$ Bogor 13614 with slide specimen IMI 71057), and found some hyphomycetous conidial structures similar to the genus Tretospora, the asexual morph of Balladynopsis. We examined a Kew specimen (K (M) 177969), but it was dried and brittle, and we were unable to find some structures 
e.g. setae, hyphopodia-like structures or even conidia as previously shown (Raciborski 1909, Sivanesan 1981). The genus Alina is separated from Balladynopsis and Balladynocallia based on intramatrial hypostroma and mycelium lacking hyphopodia. Thus, a new family Alinaceae is introduced to accommodate the monotypic genus Alina. The placement of taxa is based on morphology and therefore it is important to recollect these taxa and obtain sequence data to confirm our conclusions.

Alina jasmini Racib., Bull. int. Acad. Sci. Lett. Cracovie, Cl. sci. math. nat. Sér. B, sci. nat. 3: 375 (1909)

Index Fungorum number: IF205013; Facesoffungi number: FoF03662

Figs 51, 52

Parasitic or epiphytic on the surface of living leaves of Jasminum sp. Sexual morph: Ascomata 38-50 $\mu \mathrm{m}$ diameter $\times$ 41-55 $\mu \mathrm{m}$ high, superficial, seated on hyphae, globose to subglobose, brown, covered by brown hyphae, peridium composed of brown cells of textura angularis, lacking pseudoparaphyses. Asci $26-39 \times 14-21 \mu \mathrm{m}(\bar{x}=32 \times 17 \mu \mathrm{m}, \mathrm{n}=10)$, 8-spored, bitunicate, subglobose to clavate, sessile, thick-walled. Ascospores $12-15 \times 4-5 \mu \mathrm{m}(\bar{x}=14 \times 5$ $\mu \mathrm{m}, \mathrm{n}=10$ ), 3-4-seriate in the ascus, ovoid to obovoid, apex wider, narrower towards the lower and rounded end, 1-septate, slightly above the center, slightly constricted at the septum, brown, smooth-walled. Asexual morph: hyphomycetous, Septoidium sp., Shivamyces sp.

Material examined - INDONESIA, Java, Djasinga, on living leaves of Jasminum sp. (Oleaceae), 1900, M. Raciborski (K (M) 177969 = IMI 214481, ex-isotype).

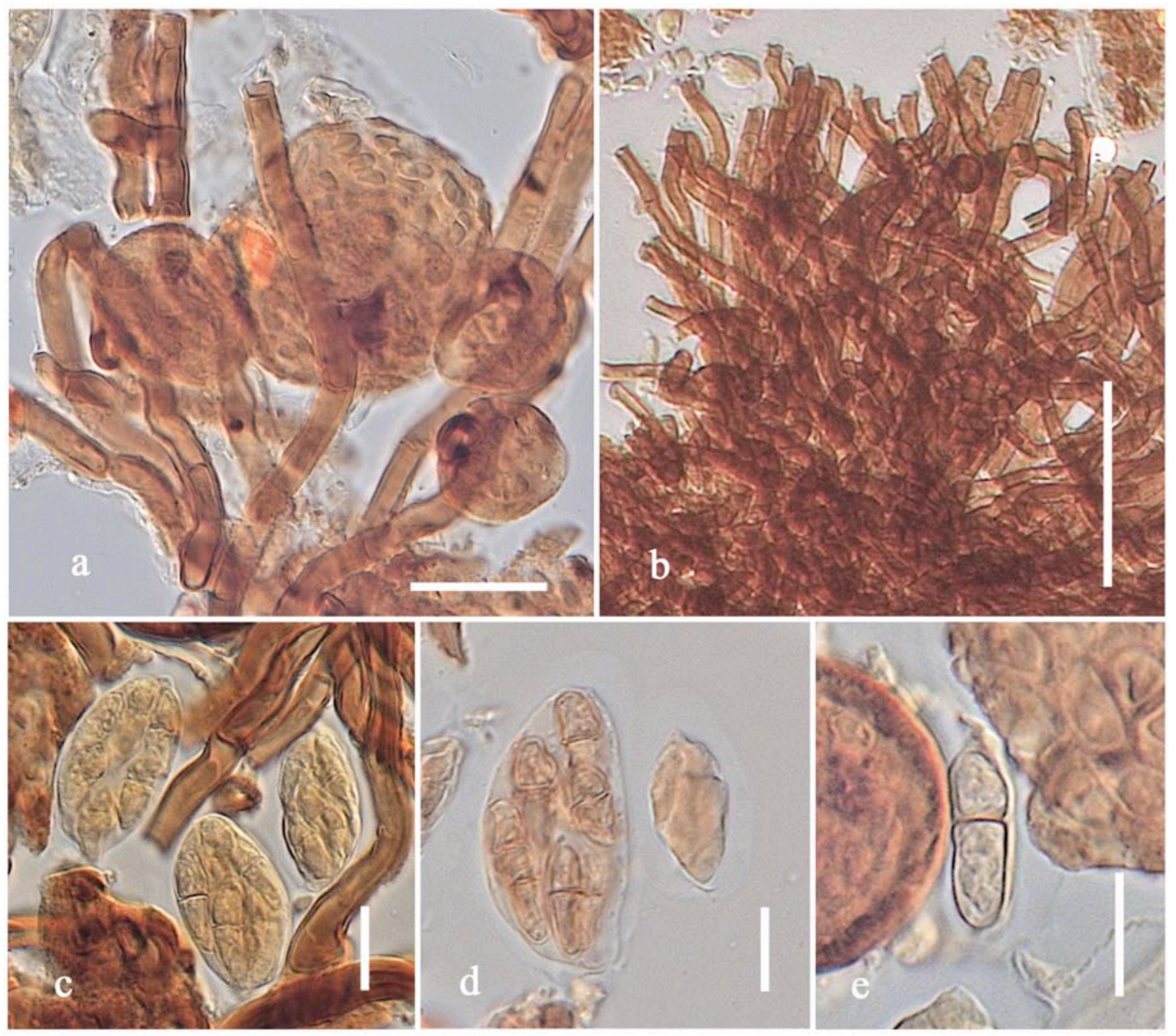

Figure 51 - Alina jasmini (K (M) 177969 = IMI 214481, ex-isotype). a Squash mount of ascomata. b Mycelia. c, d Asci. e Ascospore. Scale bars: $\mathrm{a}=20 \mu \mathrm{m}, \mathrm{b}=50 \mu \mathrm{m}, \mathrm{c}-\mathrm{e}=10 \mu \mathrm{m}$. 
Balladynaceae Boonmee \& K.D. Hyde, fam. nov.

Index Fungorum number: IF553827; Facesoffungi number: FoF03663

Parasitic on living leaves. Sexual morph: Ascomata superficial, formed on hyphae, with a subiculum, solitary, scattered, globose to subglobose, with apical pore, minutely pedicellate at the base, olivaceous brown to dark brown, with transparent wall, surrounded by a superficial mycelium network, branched, septate, with numerous dark brown, knob-like hyphopodia, with or without setae. Peridium comprising 1-2 layers of olivaceous-brown cells of textura angularis, lacking pseudoparaphyses. Asci 8-spored, bitunicate, globose to subglobose, sessile. Ascospores multiseriate in the ascus, ellipsoid, upper cell wider, 1-septate, hyaline to light brown when immature, fawn to olivaceous-brown or brown at maturity. Asexual morph: hyphomycetous, Clasterosporium sp., Tretospora sp.

Family type - Balladyna Racib.

Notes - A new family Balladynaceae is introduced to accommodate the genera Balladyna, Balladynocallia and Balladynopsis based on their parasitic lifestyle on living leaves, ascomata formed on hyphae, with or without setae, subglobose asci and 1-septate, hyaline to pigmented ascospores. With these combinations of characters, Balladynaceae can be separated from Perisporiopsidaceae and it also has a suite of characters that differ from other families of Dothideomycetes.
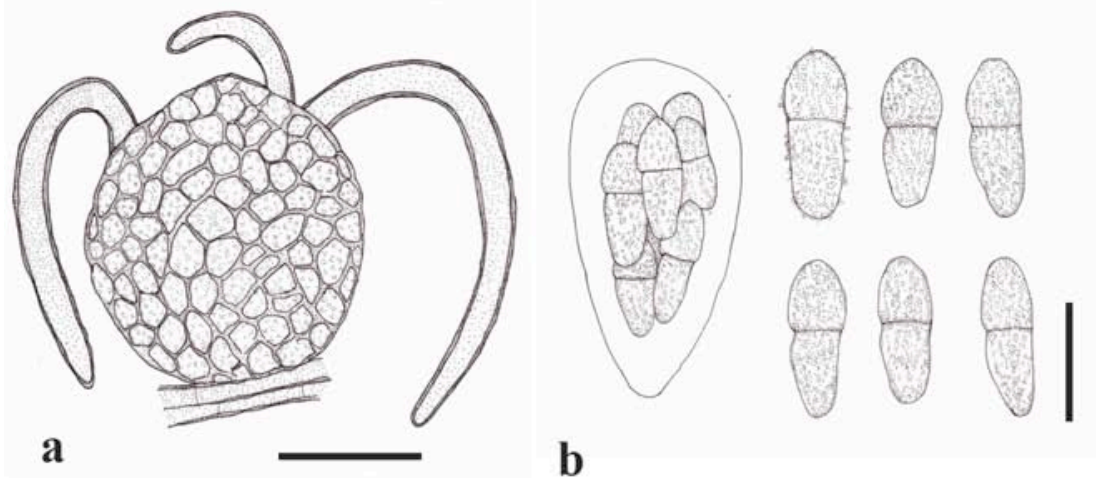

b
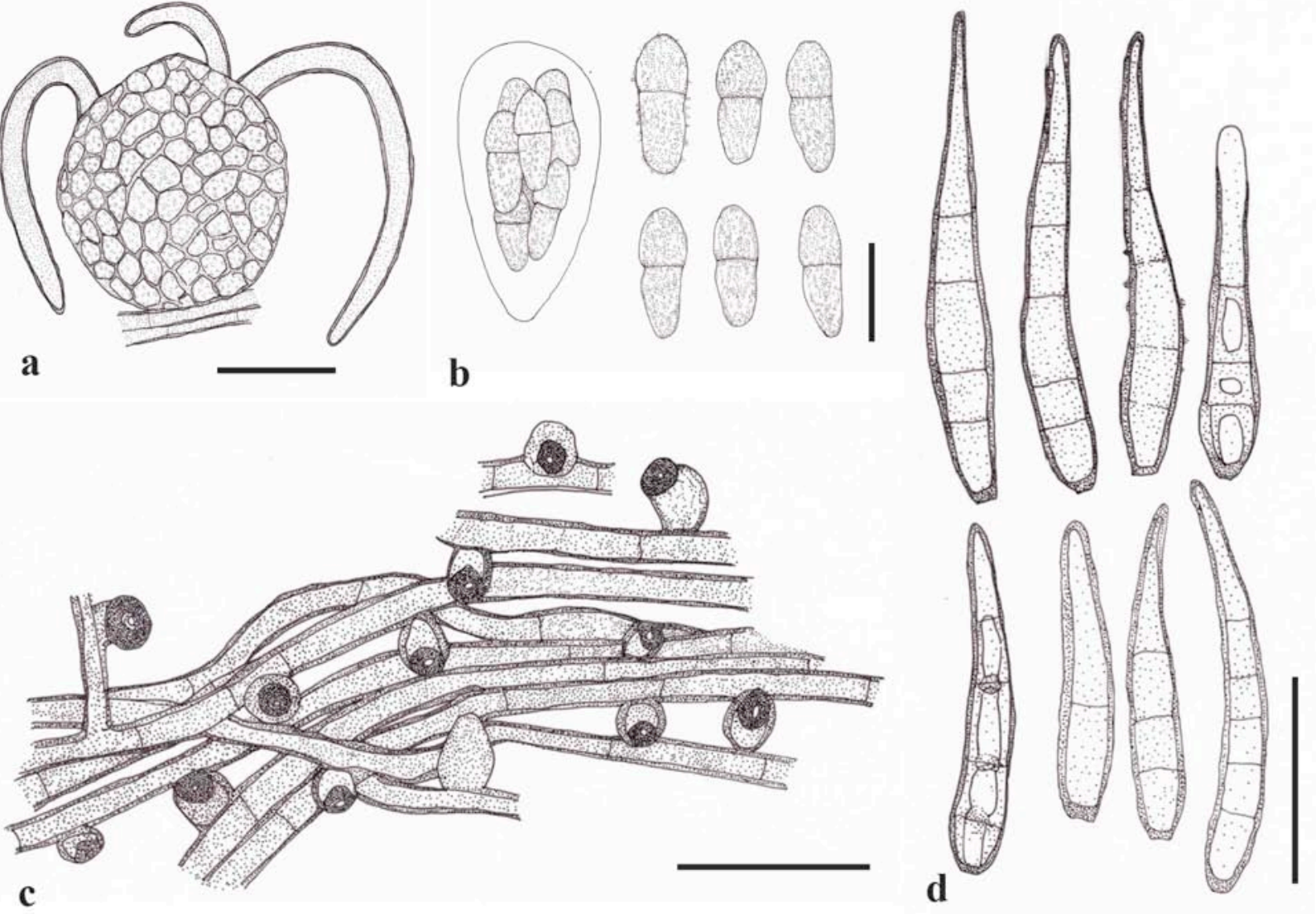

Figure 52 - Alina jasmini (redrawn from Sivanesan, 1981, Fig. 17). a Ascoma. b Ascus and ascospores. c Mycelium with conidiophores. d Hyphomycetous conidia. Scale bars: $a, c, d=25 \mu \mathrm{m}$, $\mathrm{b}=10 \mu \mathrm{m}$.

Balladyna Racib., Parasit. Alg. Pilze Java's (Jakarta) 2: 6 (1900)

Parasitic on living leaves. Sexual morph: Ascomata superficial, formed on hyphae, with a subiculum, solitary, scattered, globose to subglobose, with apical pore, minutely pedicellate at the base, olivaceous brown to dark brown, with transparent wall, surrounded by a superficial mycelium network, branched, septate, with numerous dark brown, knob-like hyphopodia, bearing dark setae. 
Peridium 3-5 $\mu \mathrm{m}$ wide, comprising 1-2 layers of olivaceous-brown cells of textura angularis, lacking pseudoparaphyses. Asci 8-spored, bitunicate, with a single ascus, globose to subglobose, sessile. Ascospores multi-seriate in the ascus, ellipsoid, upper cell wider, 1-septate, hyaline to light brown when immature, fawn to olivaceous brown, smooth-walled to slightly ornamented. Asexual morph: hyphomycetous, Clasterosporium sp., Tretospora sp. (Thaung 1976, Kirk et al. 2008, Seifert et al. 2011).

Type species - Balladyna gardeniae Racib.

Notes - Raciborski (1900) described and introduced the genus Balladyna based on the type species B. gardeniae, which was found on living leaves of Gardenia lucida from Indonesia. Morphologically, the genus is characterised by ascomata formed on hyphae, mycelium with numerous hyphopodia-like structures, lack of pseudoparaphyses and a single bitunicate ascus. The genus currently has 54 species epithets, but only 41 species are listed under Balladyna (Index Fungorum 2017). Seifert et al. (2011) referenced its asexual morphs to Clasterosporium sp. found in Balladyna vanderystii var. ferulae-foetidae and Tretospora sp. found in Balladyna negrii. In our re-examined isotype specimen BPI 691469, we were unable to find the asexual morph of $B$. gardeniae Racib. According to morphological characters, Balladyna can be raised to the family Balladynaceae. All species lack sequence data.

Balladyna gardeniae Racib., Parasit. Alg. Pilze Java's (Jakarta) 2: 6 (1900)

Index Fungorum number: IF218036; Facesoffungi number: FoF03664

Fig. 53

Parasitic on living leaves of Gardenia lucida Roxb. Sexual morph: Ascomata (45-)51-67(80) $\mu \mathrm{m}$ diameter $\times(56-) 62-77.5(-88) \mu \mathrm{m}$ high, superficial, formed on hyphae, with a subiculum, solitary, scattered, globose to subglobose, with apical pore, minutely pedicellate at the base, olivaceous brown to dark brown, with transparent wall, surrounded by a superficial mycelium network, branched, septate, with numerous dark brown, knob-like hyphopodia, (8-)10-14.5 $\mu \mathrm{m} \times$ 6-9(-11) $\mu \mathrm{m}$, bearing dark setae, 93-98 $\mu \mathrm{m}$ long $\times 7-11 \mu \mathrm{m}$ wide. Peridium $3-5 \mu \mathrm{m}$ wide, comprising 1-2 layers of olivaceous-brown cells of textura angularis, lacking pseudoparaphyses. Asci (35-)41-45 $\times(29-) 33.5-41 \mu \mathrm{m}(\bar{x}=41 \times 35.5 \mu \mathrm{m}, \mathrm{n}=10), 8$-spored, bitunicate, one per ascus, globose to subglobose, sessile. Ascospores 20-23 $211-13 \mu \mathrm{m}(\bar{x}=22 \times 12 \mu \mathrm{m}, \mathrm{n}=10), 8$ spored, multi-seriate, ellipsoid, upper cell wider, ends rounded, 1-septate, with constricted and darkened at the septum, hyaline to light brown when immature, fawn to olivaceous brown, smoothwalled to slightly ornamented. Asexual morph: Undetermined, however, hyphopodia-like structures produced on hyphae.

Material examined - INDONESIA, Java, Bogor, on living leaves of Gardenia lucida Roxb. (Rubiaceae), M. Raciborski Nr. 88 (BPI 691469, isotype).

Balladynocallia Bat. (Hansf.) Bat., Atas Inst. Micol. Univ. Recife 2: 216 (1965)

Parasitic on living leaves. Colonies amphigenous, dark pigmented, up to $3 \mathrm{~mm}$ diameter, superficial mycelium and hyphopodia, pale brown, branched, densely reticulate, with somewhat undulating hyphae, up to $4 \mu \mathrm{m}$ thick, lacking setae. Hyphopodia unilateral to alternate, concolourous with hyphae, continuous, ovoid, hemisphaerical to irregular. Sexual morph: Ascomata up to $90 \mu \mathrm{m}$ diameter, densely dispersed, subglobose to ovate, with an irregular apical pore, glabrous, black, numerous, short-stalked, lacking pseudoparaphyses. Peridium 4-6 $\mu \mathrm{m}$ wide, comprising brown cells of textura angularis, with granular appearance. Asci 8-spored, bitunicate, with 2-6-asci in ascoma, broadly ellipsoid to saccate, sessile, upper cell wider and rounded, narrower towards the lower end. Ascospores multi-seriate, ovoid to obovoid, upper cell wider, narrower towards the lower and rounded end, 1-septate, somewhat unequally, dark brown. Asexual morph: Undetermined.

Type species - Balladynocallia glabra (Hansf.) Bat.

Notes - Balladynocallia was introduced by Batista et al. (1965) to accommodate two species B. amazonensis Bat. \& A.A. Silva and B. glabra (Hansf.) Bat. (type species) and is characterised by ascomata lacking setae. Sivanesan (1981) included B. magna (Eboh \& Cain) Sivan. as it shares 
morphology typical of Balladynocallia. We re-examined the type specimen Balladynocallia glabra from Kew (K (M) 177971, holotype = ex herb. IMI 5081a), but it was not in good condition and we were unable to see microscopic structures. Based on Sivanesan's (1981) descriptions and illustrations, its morphology and substrate are consistent with Balladyna in Balladynaceae. We therefore include Balladynocallia in the family Balladynaceae.

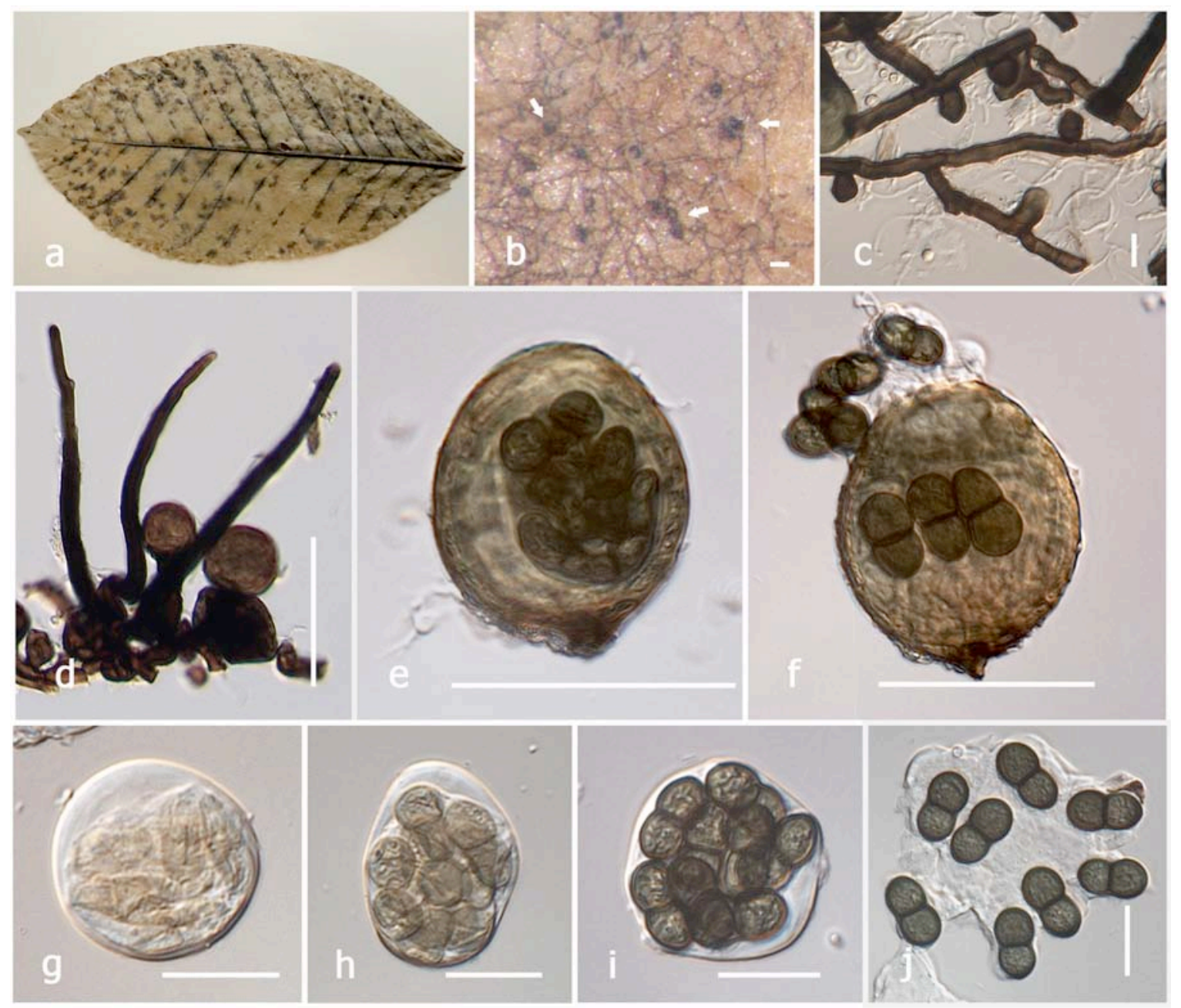

Figure 53 - Balladyna gardenia (BPI 691469, isotype). a Herbarium specimen and habit on leaf. b Appearance of ascomata on leaf surface. c Close up of hyphae with hyphopodia. $d$ Setae. e, $f$ Squash mount of ascomata. $g-i$ Asci when immature and mature. $j$ Ascospores. Scale bars: $b=50$ $\mu \mathrm{m}, \mathrm{c}=10 \mu \mathrm{m}, \mathrm{d}-\mathrm{f}=50 \mu \mathrm{m}, \mathrm{g}-\mathrm{j}=20 \mu \mathrm{m}$.

Balladynocallia glabra (Hansf.) Bat., Atas Inst. Micol. Univ. Recife 2: 216 (1965)

$\equiv$ Balladynastrum glabrum Hansf., Proc. Linn. Soc. London 157: 157 (1946) [1944-45]

Index Fungorum number: IF326909; Facesoffungi number: FoF03665

Figs 54, 55

Parasitic on living leaves of Rutidea rufipilis Hiern. Ascomata 54-77 $\mu \mathrm{m}$ diameter $\times 61-75(-$ 91) $\mu \mathrm{m}$ high, superficial, solitary, scattered, globose to subglobose, dark brown, with apical pore, but asci and ascospores absent.

Notes - Sivanesan (1981) described Balladynocallia glabra from the holotype (5081a) and other herbarium specimens (redrawn in Fig. 55). Colonies amphigenous, dark pigmented, up to 3 $\mathrm{mm}$ diameter, superficial mycelium with hyphopodia, pale brown, branched, densely reticulate, somewhat undulating hyphae, up to $4 \mu \mathrm{m}$ thick, lacking setae. Hyphopodia unilateral to alternate, concolourous with hyphae, continuous, ovoid, hemisphaerical to irregular, 6-12 $\mu \mathrm{m} \times 6-10 \mu \mathrm{m}$. Sexual morph: Ascomata up to $90 \mu \mathrm{m}$ diameter, densely dispersed, subglobose to ovate, with an irregular apical pore, glabrous, black, numerous, short-stalked, lacking pseudoparaphyses. 
Peridium 4-6 $\mu \mathrm{m}$ wide, comprising brown cells of textura angularis, with granular appearance. Asci $60 \times 40 \mu \mathrm{m}, 8$-spored, bitunicate, with 2-6 asci in ascoma, broadly ellipsoid to saccate, sessile, upper cell wider and rounded, narrower towards the lower end. Ascospores 18-21 $\times 8-10 \mu \mathrm{m}$, multi-seriate, ovoid to obovoid, upper cell wider, narrower towards the lower and rounded end, 1septate, constricted at the septum, somewhat unequally, dark brown, smooth-walled. Asexual morph: Undetermined.

Material examined - UGANDA, Entebbe, on leaves of Rutidea rufipilis Hiern (Rubiaceae), November 1940, G.C. Hansford 2916 (K (M) 177971, holotype = IMI 5081a, ex herb.).
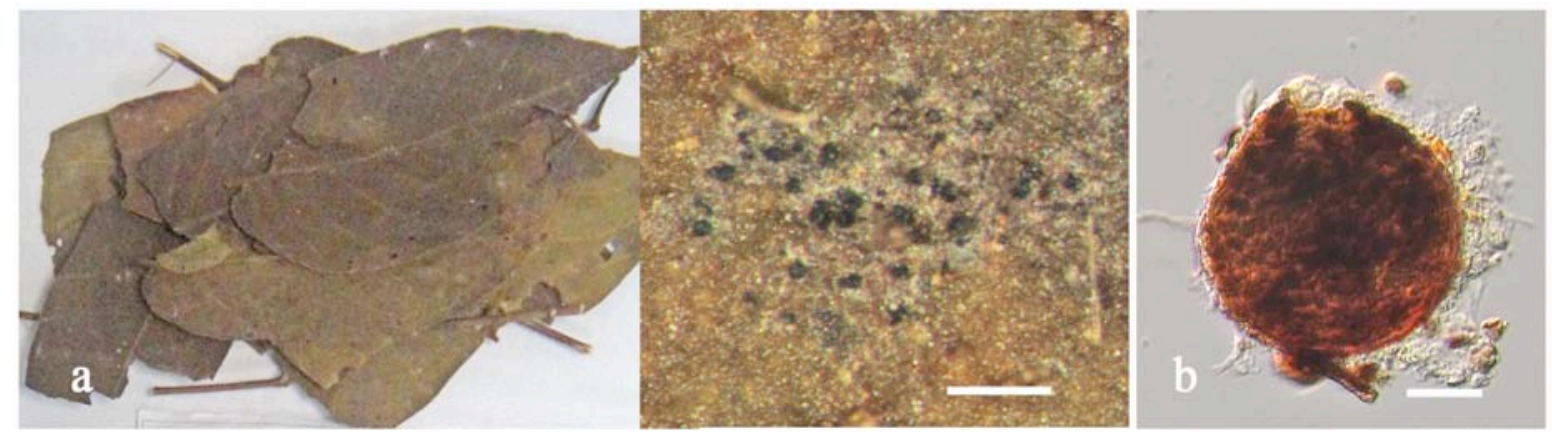

Figure 54 - Balladynocallia glabra (K (M) 177971, holotype). a Herbarium specimen and habit on leaves. $b$ Squash mount of ascoma. Scale bars: $a=200 \mu \mathrm{m}, \mathrm{b}=20 \mu \mathrm{m}$.
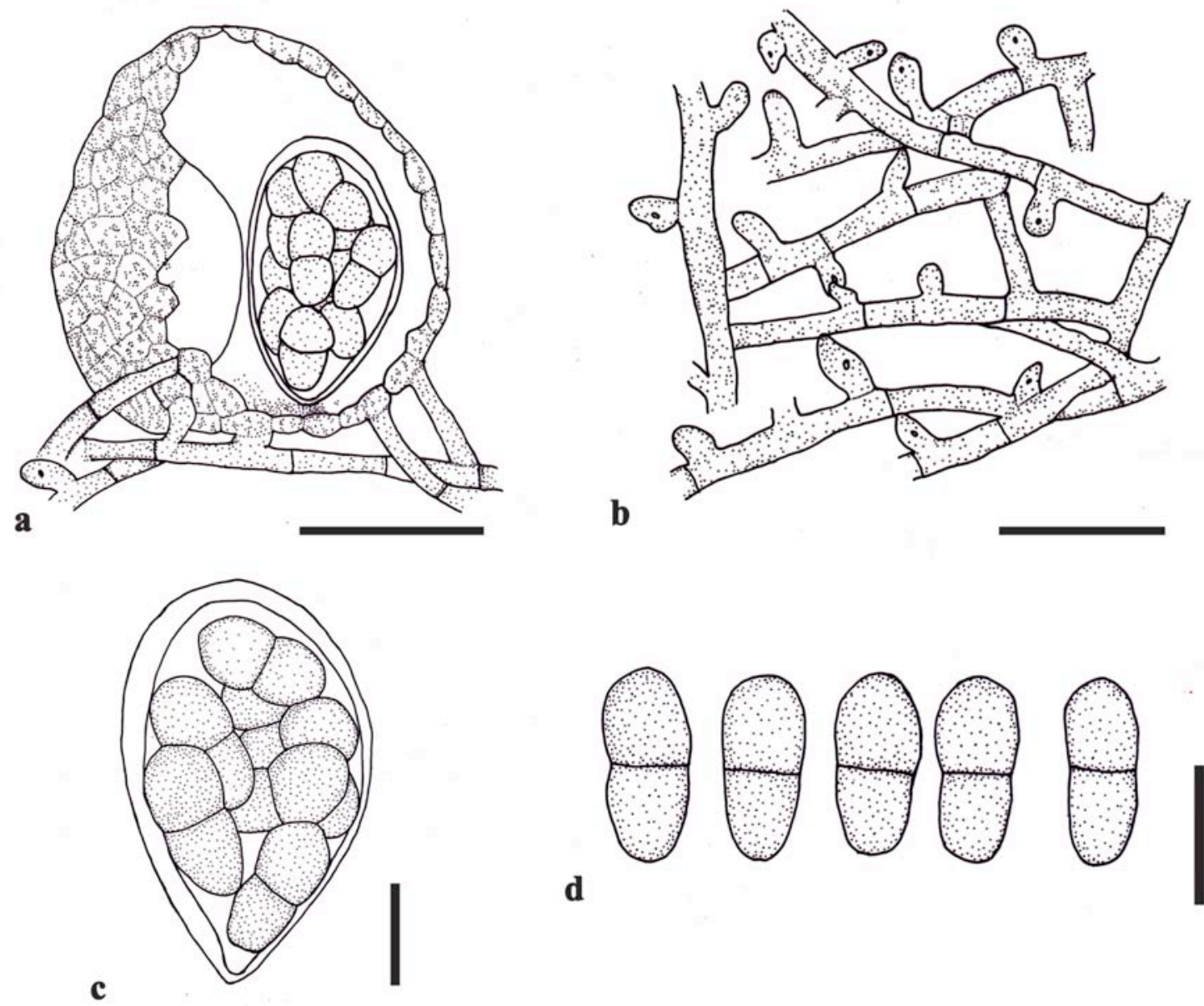

d

Figure 55 - Balladynocallia glabrum (redrawn from Sivanesan 1981, Fig. 19). a Ascoma. b Superficial mycelium with hyphopodia. c Ascus. $d$ Ascospores. Scale bars: $a, b=25 \mu \mathrm{m}, \mathrm{c}=10$ $\mu \mathrm{m}, \mathrm{d}=5 \mu \mathrm{m}$. 
Balladynopsis Theiss. \& Syd., Annls mycol. 15(6): 475 (1918) [1917]

Parasitic on living leaves. Sexual morph: Ascomata superficial, solitary, scattered, globose to subglobose, black, with apical pore, seated on mycelium colonies, radial hyphae, branched, with hyphopodia-like structures, dark brown, with setae, thickened, black, apex subacute and bright, lacking pseudoparaphyses. Peridium comprising 2-3 layers of relatively large, hyaline to dark brown cells of textura angularis. Asci 8 -spored, bitunicate, globose to subglobose, sessile, apically thickened and rounded. Ascospores multi-seriate, fusoid to ellipsoid, oblong, upper cell wider, apex rounded, tapering towards the narrow and subacute base, 1-septate, supra-median, hyaline when immature, brown at maturity, smooth to slightly verruculose. Asexual morph: Undetermined.

Type species - Balladynopsis philippinensis Syd. \& P. Syd.

Notes - Theissen \& Sydow (1917) introduced the genus Balladynopsis with B. philippinensis (Basionym: Henningsomyces philippinensis Syd. \& P. Syd.) characterised by mycelium with hyphopodia, ascomata with setae, bitunicate asci and 1-septate brown ascospores. Balladynopsis is included in Balladynaceae based on its superficial hyphae with hyphopodia, subglobose asci and 1septate ascospores. The genus comprises ten species epithets (Index Fungorum 2017).

Balladynopsis philippinensis Syd. \& P. Syd., Annls mycol. 15(6): 476 (1918) [1917]

$\equiv$ Henningsomyces philippinensis Syd. \& P. Syd., Philipp. J. Sci., C, Bot. 9(2): 161 (1914)

Index Fungorum number: IF222867; Facesoffungi number: FoF03666

Parasitic on living leaves of Morinda spp. Sexual morph: Ascomata 37-59 $\mu \mathrm{m}$ diameter $\times$ 40-58 $\mu \mathrm{m}$ high, superficial, solitary, scattered, globose to slightly subglobose, black, with apical pore, seated on mycelial colonies, radial hyphae, branched, with hyphopodia-like structures, dark brown, with setae, 45-60 $\mu \mathrm{m}$ long $\times$ 6-7 $\mu \mathrm{m}$ wide, thickened, black, apex subacute and bright, lacking pseudoparaphyses. Peridium 4-4.5 $\mu \mathrm{m}$ wide, comprising 2-3 layers of relatively large, hyaline to dark brown cells of textura angularis. Asci (33-)36.5-40(-49) $\times(25-) 30-39 \mu \mathrm{m}(\bar{x}=40$ $\times 31 \mu \mathrm{m}, \mathrm{n}=10), 8$-spored, bitunicate, globose to subglobose, sessile, apically thickened and rounded. Ascospores 20-25.5(-27) $\times 7-8 \mu \mathrm{m}(\bar{x}=24 \times 8 \mu \mathrm{m}, \mathrm{n}=10)$, multi-seriate, fusoid to ellipsoid, oblong, upper cell wider, apex rounded, tapering towards the narrow and subacute base, 1-septate, constricted at the septum, supra-median, hyaline when immature, brown at maturity, smooth-walled to lightly verruculose. Asexual morph: Undetermined.

Material examined - PHILIPPINES, Palawan, Taytay, on living leaves of Morinda spp. (Rubiaceae), April 1913, E.D. Merrill No. 8823 (S-F10387, holotype).

\section{Botryosphaeriaceae Theiss. \& Syd.}

Currently, Botryosphaeriales includes eight families of biotrophic, necrotrophic and saprobic species common on wood in terrestrial habitats (Hyde et al. 2013, Dissanayake et al. 2016, Wijayawardene et al. 2017). Characteristics comprise immersed to superficial, globose to subglobose, uni to multi-loculate ascomata, with apical ostioles, bitunicate and fissitunicate, sessile to short pedicellate and thick-walled asci, and occasionally with an ocular chamber, aseptate to septate, fusoid to ellipsoid or ovoid, hyaline to brown ascospores. The asexual morph is coelomycetous and has hyaline to brown conidia (Hyde et al. 2013). Myxophora and Pilgeriella share a similar morphology with genera in Botryosphaeriaceae, we therefore include these two genera in this family.

Myxophora Döbbeler \& Poelt, Mitt. bot. St Samml., Münch. 14: 315 (1978)

Hyperparasitic, saprobic, algicolous or lichenicolous, on dead parts of leaves of moss. Sexual morph: Ascomata superficial, globose to subglobose, dark brown, with apical pore, lacking superficial mycelium. Peridium comprising 3-4 layers of dark brown cells of textura angularis. Hamathecium comprising hyaline, pseudoparaphyses, embedded in a gelatinous matrix. Asci 8spored, bitunicate, fissitunicate, saccate, oblong ellipsoid to cylindrical clavate, sessile or with short pedicel, apex rounded, with minute ocular chamber, thick-walled. Ascospores 1-2-seriate, oblong 
ellipsoid to fusiform, subglobose, aseptate, hyaline, with large guttules, smooth-walled. Asexual morph: Undetermined.

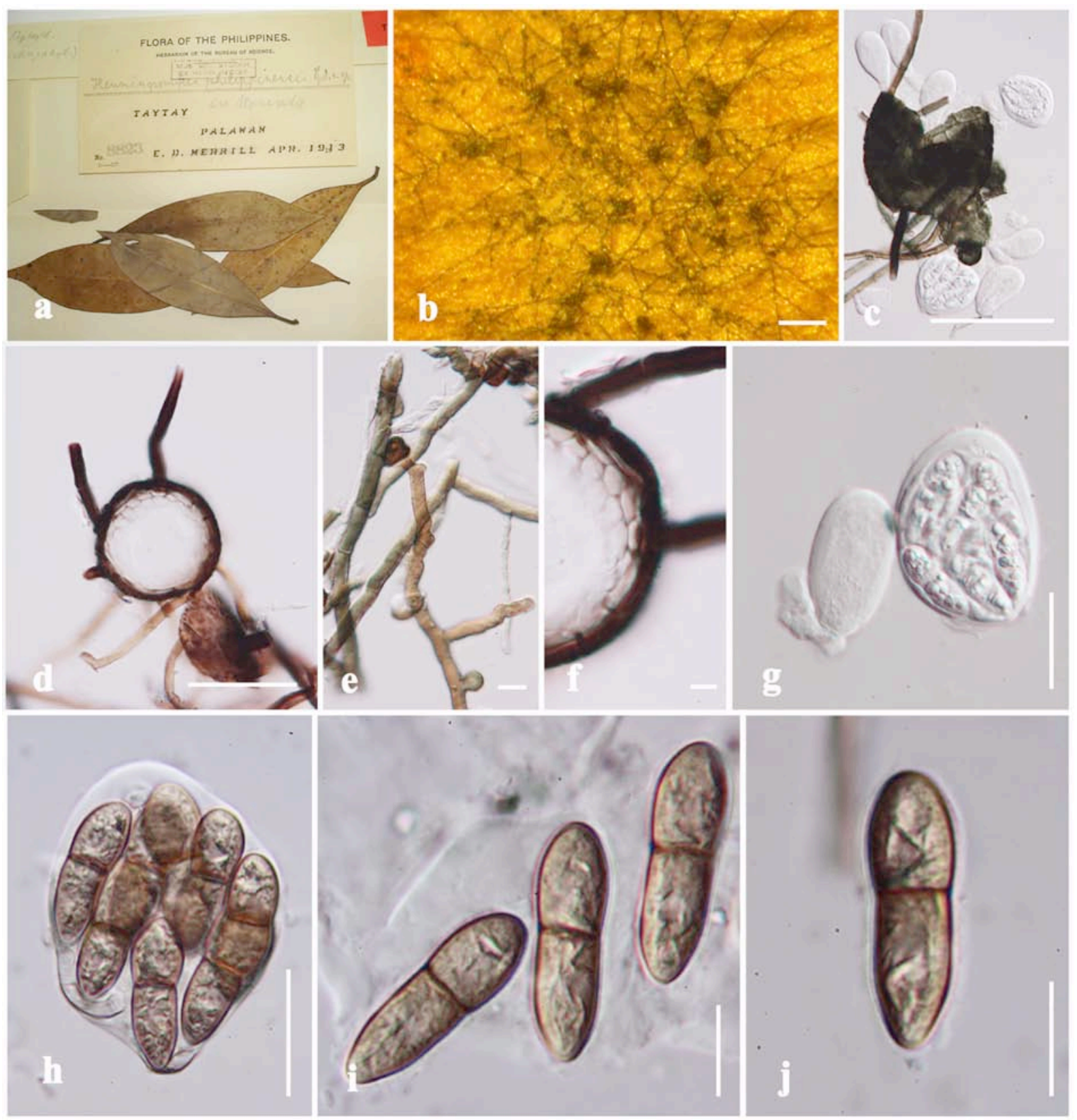

Figure 56 - Balladynopsis philippinensis (S-F10387, holotype). a Herbarium specimen and habit on leaves. b Appearance of ascomata on leaf surface. c Squash mount of ascoma. d Section of ascoma with setae. e Close up of mycelium with hyphopodia-like structures. $\mathrm{f}$ Close up of peridium. $\mathrm{g}-\mathrm{h}$ Immature and mature asci. $\mathrm{i}-\mathrm{j}$ Ascospores. Scale bars: $\mathrm{b}=200 \mu \mathrm{m}, \mathrm{c}, \mathrm{d}=50 \mu \mathrm{m}, \mathrm{e}$, $\mathrm{i}, \mathrm{j}=10 \mu \mathrm{m}, \mathrm{f}=5 \mu \mathrm{m}, \mathrm{g}, \mathrm{h}=20 \mu \mathrm{m}$.

Type species - Myxophora amerospora Döbbeler \& Poelt

Notes - Myxophora was introduced by Döbbeler (1978) to accommodate M. amerospora Döbbeler \& Poelt (type species) which was found on moss (Campylium halleri) and placed in Dimeriaceae, Dothideales. Subsequently, six new species were added to the genus, i.e. $M$. apotheciicola Nik. Hoffm. \& Hafellner, M. leptogiophila Nik. Hoffm. \& Hafellner, M. ovalispora Nik. Hoffm. \& Hafellner, M. placynthii Nik. Hoffm. \& Hafellner, M. tetraspora Nik. Hoffm. \& Hafellner and M. tjibodensis Döbbeler on the basis of bitunicate asci and unicellular hyaline ascospores (Döbbeler 1995, Hoffmann \& Hafellner 2000). Barr (1997) accepted Myxophora in 
Pseudoperisporiaceae and this was followed by Eriksson \& Hawksworth (1993) and Hawksworth et al. (1995). Myxophora shares common features of ascomata, asci and ascospores with Cleistosphaera, Parodiellina, Pilgeriella and is atypical of Pseudoperisporiaceae. These genera are therefore excluded from Pseudoperisporiaceae and are transferred to Botryosphaeriaceae, Botryosphaeriales in this study. Fresh collections of the type, epitypification and DNA sequence data are required to confirm the taxonomic rank of Myxophora.

Myxophora amerospora Döbbeler \& Poelt, Mitt. bot. St Samml., Münch. 14: 315 (1978)

Index Fungorum number: IF318440; Facesoffungi number: FoF03667

Fig. 57

Hyperparasitic, saprobic, algicolous or lichenicolous, on dead parts of leaves of Campylium halleri (Hedw.) M. Fleisch. Sexual morph: Ascomata (102-)108-120(-134) $\mu \mathrm{m}$ diameter $\times(88-$ )97-105(-108) $\mu \mathrm{m}$ high, superficial, globose to subglobose, dark brown, with apical pore, lacking superficial mycelium. Peridium 13-15 $\mu \mathrm{m}$ wide, comprising 3-4 layers of dark brown cells of textura angularis. Hamathecium ca. $1-1.5(-2) \mu \mathrm{m}$ wide, comprising hyaline, pseudoparaphyses, embedded in a gelatinous matrix. Asci (34-)37-46(-48) $\times(10-) 13-15(-16) \mu \mathrm{m}(\bar{x}=41 \times 13 \mu \mathrm{m}, \mathrm{n}$ $=20), 8$-spored, bitunicate, fissitunicate, saccate, oblong ellipsoid to cylindrical to clavate, sessile or with short pedicel, apex rounded, with minute ocular chamber, thick-walled. Ascospores (10)11-12.5 × 5-6(-7) $\mu \mathrm{m}(\bar{x}=11.5 \times 6 \mu \mathrm{m}, \mathrm{n}=20), 1-2$-seriate, oblong ellipsoid to fusiform, subglobose, aseptate, hyaline, with large guttules, smooth-walled. Asexual morph: Undetermined.

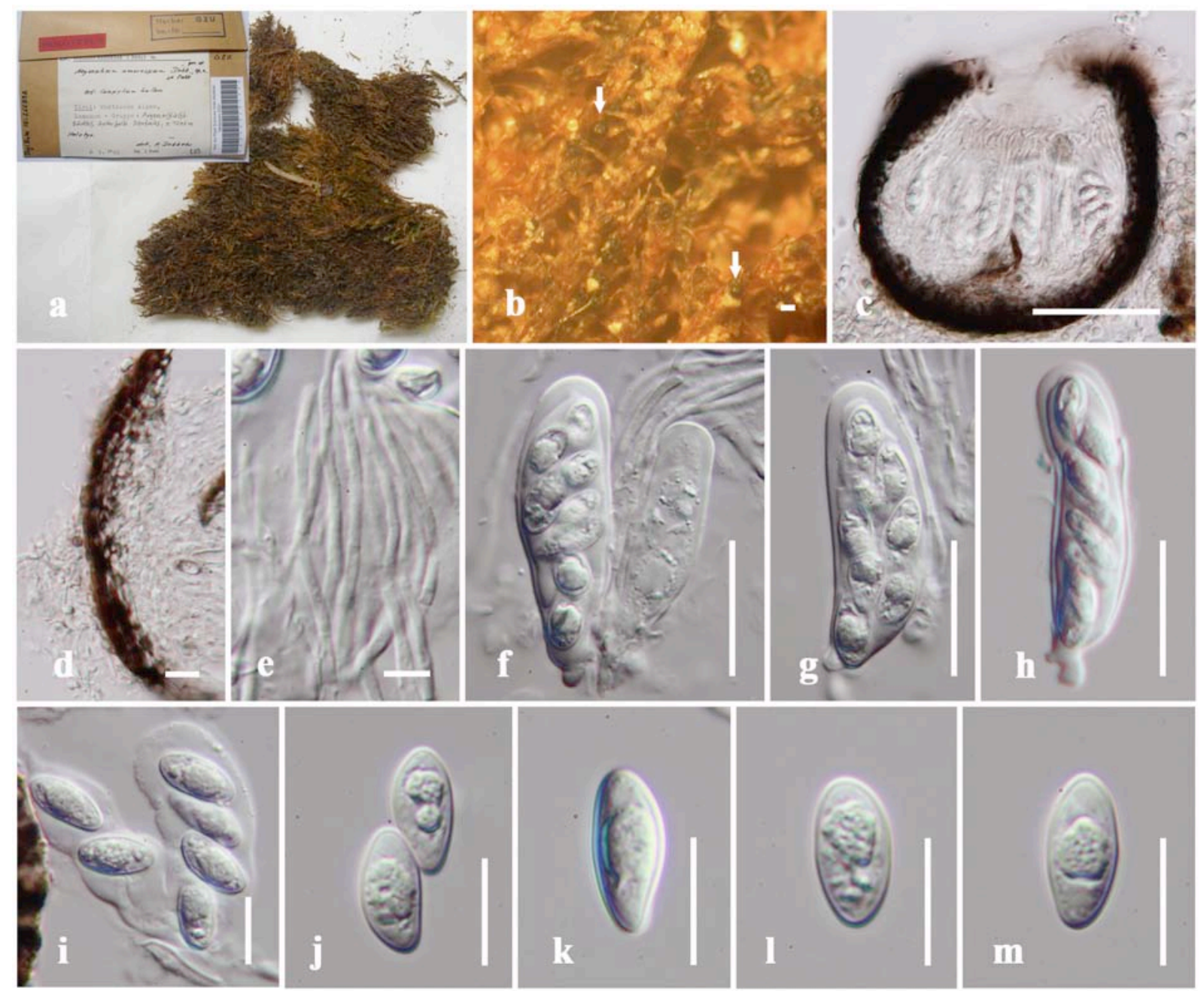

Figure 57 - Myxophora amerospora (GZU 000291904, holotype). a Herbarium specimen and habit on leaves. b Appearance of ascomata on leaf surface. c Section of ascoma. d Peridium. e Pseudoparaphyses. f-h Asci. i-m Ascospores. Scale bars: b, $\mathrm{c}=100 \mu \mathrm{m}, \mathrm{d}, \mathrm{i}-\mathrm{m}=10 \mu \mathrm{m}, \mathrm{e}=5 \mu \mathrm{m}$, $\mathrm{f}-\mathrm{h}=20 \mu \mathrm{m}$. 
Material examined - AUSTRIA, Tyrol, Rhaetian Alps, Samnaun-Group, Argenschlucht southern Serfaus, alt. $\pm 1200 \mathrm{~m}$., on hairy leaves of Campylium halleri (Hedw.) M. Fleisch. (Amblystegiaceae), 6 September 1972, J. Poelt (DigiBota ID 266898, GZU 000291904, holotype).

Pilgeriella Henn., Hedwigia 39(Beibl.): (137) (1900)

Parasitic on living leaves. Sexual morph: Ascomata superficial, gregarious, solitary, seated on a subiculum, globose to subglobose, obovoid, dark brown, with apical ostiole. Peridium comprising 3-4 layers of dark brown cells of textura angularis. Hamathecium 5-8(-10) $\mu \mathrm{m}$ wide, comprising sparse, branched, septate, anastomosed, pseudoparaphyses. Asci 8-spored, bitunicate, fissitunicate, broadly obovoid to subclavate, with short pedicel, apically thickened, with an ocular chamber. Ascospores 2-3-seriate, ellipsoidal oblong, tapering towards the ends, aseptate, hyaline, sometimes with granulate cells. Asexual morph: Undetermined.

Type species - Pilgeriella perisporioides Henn.

Notes - Pilgeriella was introduced by Hennings (1900) with P. perisporioides as the type species and placed in the family Trichosphaeriaceae. von Höhnel (1910) placed this genus in Botryosphaeria. Hansford (1946) suggested that $P$. perisporioides should be transferred to Guignardiella Sacc. \& P. Syd. (Dothideaceae) based on its ascospores. von Arx \& Müller (1975) placed Pilgeriella in Parodiellinaceae based on its parasitic mode on leaves. The genus was moved to the family Parodiopsidaceae (Toro 1952, Sivanesan 1984, Kirk et al. 2008, Lumbsch and Huhndorf 2010, Wijayawardene et al. 2017). Hyde et al. (2013) listed Pilgeriella in the family Perisporiopsidaceae. We re-examined the isotype specimen of $P$. perisporioides from $\mathrm{S}$ herbarium (F12920) in which the asci and ascospores showed morphology similar to taxa in Botryosphaeriaceae, but its ascomata were atypical of Botryosphaeria. Therefore, we suggest that this genus should be placed in Botryosphaeriaceae as asci are broadly obovoid to subclavate, thickwalled and short pedicellate, with an ocular chamber and ascospores are ellipsoidal oblong, aseptate and hyaline. Currently the genus comprises two species, P. anacardii (Bat. et al.) Arx \& E. Müll. and $P$. perisporioides Henn. Although, Seifert et al. (2011) mentioned that an asexual morph in Septoidium, we could not find any asexual morph on the isotype specimen.

Pilgeriella perisporioides Henn., Hedwigia 39(Beibl.): (137) (1900)

Index Fungorum number: IF221107; Facesoffungi number: FoF03668

Fig. 58

Parasitic on living leaves of Loranthus sp. Sexual morph: Ascomata 278-318 $\mu \mathrm{m}$ diameter $\times$ 323-391 $\mu \mathrm{m}$ high, superficial, gregarious, solitary, seated on a subiculum, globose to subglobose, obovoid, dark brown, with apical ostiole. Peridium 40-45 $\mu \mathrm{m}$ wide, comprising 3-4 layers of dark brown cells of textura angularis. Hamathecium 5-8(-10) $\mu \mathrm{m}$ wide, comprising sparse, branched, septate, anastomosed, hyaline, pseudoparaphyses, constricted at the septa. Asci (138-)159-190($201) \times 42-61 \mu \mathrm{m}(\bar{x}=173 \times 50.5 \mu \mathrm{m}, \mathrm{n}=20), 8$-spored, bitunicate, fissitunicate, broadly obovoid to subclavate, with short pedicel, apically thickened, with an ocular chamber. Ascospores (46.5)50-61 $\times 19-23 \mu \mathrm{m}(\bar{x}=54 \times 21 \mu \mathrm{m}, \mathrm{n}=20), 2-3$-seriate, ellipsoidal oblong, tapering towards the ends, aseptate, hyaline, sometimes with granulate cells, smooth-walled. Asexual morph: Undetermined.

Material examined - BRAZIL, Mato Grosso, larch forest on the shore Kulischu Lake, on leaves of Loranthus sp. (Loranthaceae), 14 March 1899, Pilger (S-F12920, isotype).

Cleistosphaeraceae Boonmee \& K.D. Hyde, fam. nov.

Index Fungorum number: IF553828; Facesoffungi number: FoF03669

Parasitic or saprobic on leaves. Sexual morph: Ascomata superficial, grouped to solitary, globose to subglobose, dark brown, covered with dark brown mycelium, branched, septate, with subglobose and dark brown hyphopodia. Hamathecium comprising sparse, septate, pseudoparaphyses. Peridium comprising dark brown cells of textura angularis. Asci 8-spored, bitunicate, ovoid to broadly clavate, sessile or with knob-like pedicel. Ascospores ellipsoid-oblong, 1-celled, hyaline to pale grey, smooth-walled. Asexual morph: coelomycetous. 


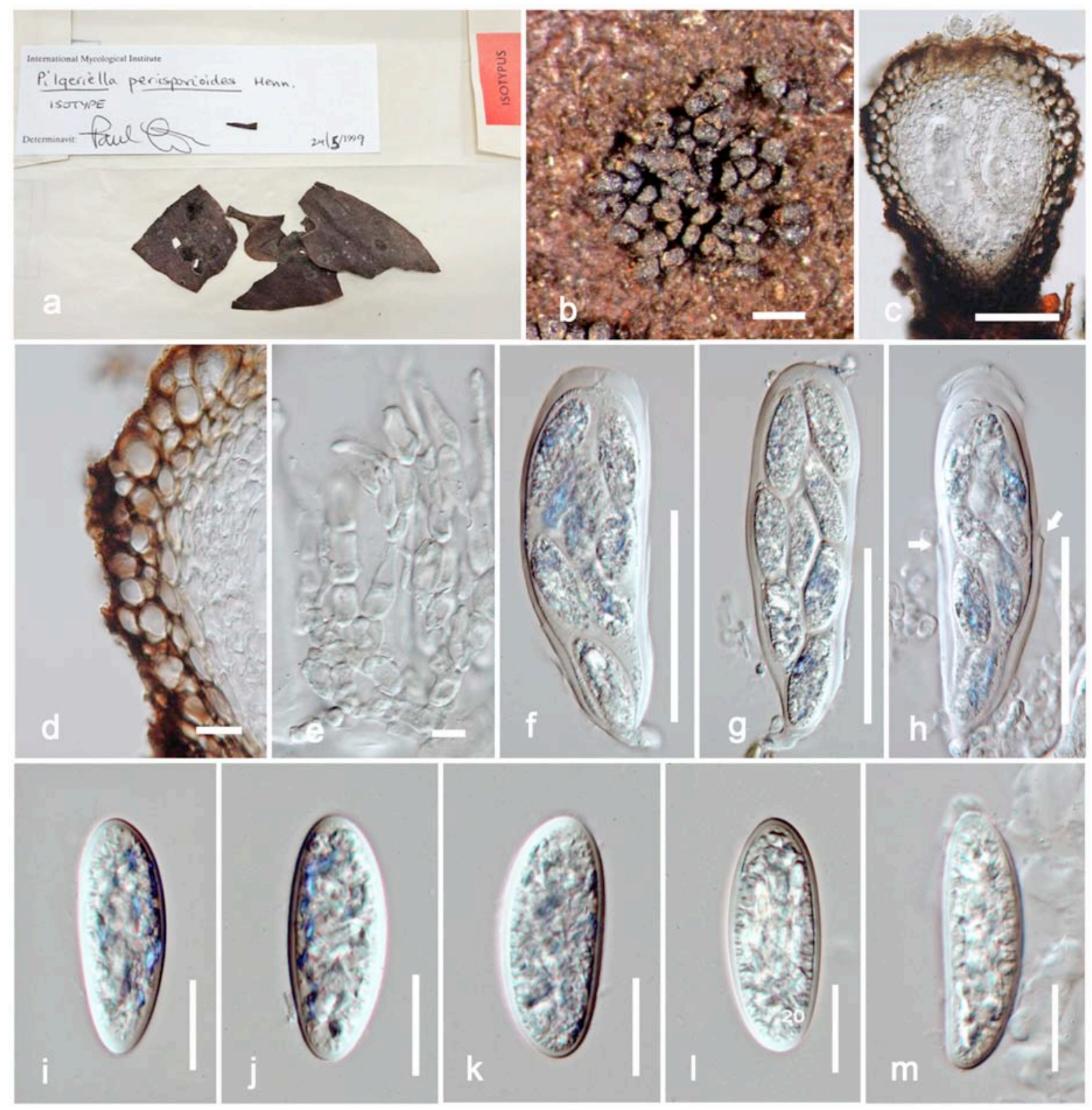

Figure 58 - Pilgeriella perisporioides (S-F12920, isotype). a Herbarium specimen and habit on leaves. b Appearance of ascomata on leaf surface. c Section of ascoma. d Peridium. e Hamathecium. $\mathrm{f}-\mathrm{h}$ Asci. i-m Ascospores. Scale bars: $\mathrm{b}=500 \mu \mathrm{m}, \mathrm{c}, \mathrm{f}-\mathrm{h}=100 \mu \mathrm{m}, \mathrm{e}=10 \mu \mathrm{m}, \mathrm{i}-\mathrm{m}$ $=20 \mu \mathrm{m}$.

Family type - Cleistosphaera Syd. \& P. Syd.

Notes - The new family Cleistosphaeraceae is introduced to accommodate the monotypic genus Cleistosphaera, which is typified by C. macrostegia Syd. \& P. Syd. Cleistosphaeraceae has superficial, sphaerical, dark brown ascomata, mycelium with hyphopodia, sparse pseudoparaphyses, ovoid to broadly clavate asci and ellipsoid oblong, 1-celled, hyaline ascospores, with granular contents and a gelatinous sheath. The family shares some similar characters of asci and ascospores with Botryosphaeriaceae. However, Cleistosphaera differs from Botryosphaeriaceae by its ascomata features, mycelium with hyphopodia and sparse pseudoparaphyses.

Cleistosphaera Syd. \& P. Syd., Annls mycol. 14(1/2): 74 (1916)

Parasitic or saprobic on leaves. Sexual morph: Ascomata superficial, grouped or solitary, uniloculate, globose to subglobose, with a subiculum, with apical pore, dark brown, covered with 
5-9 $\mu \mathrm{m}$ wide, branched, septate, dark brown mycelium, hyphopodia 12-15 $\mu \mathrm{m}$ wide, subglobose and dark brown. Hamathecium comprising sparse, septate, hyaline, pseudoparaphyses constricted at the septa. Peridium comprising 2-3 layers of dark brown cells of textura angularis. Asci 8-spored, bitunicate, ovoid to broadly clavate, sessile or with knob-like pedicel, apically thickened and rounded, with small ocular chamber. Ascospores 2-3-seriate, ellipsoid to oblong, 1-celled, hyaline to pale grey, surrounded by thin gelatinous sheath, with granular contents. Asexual morph: coelomycetous associated with Cleistosphaera macrostegia. Pycnidia superficial, globose to subglobose, dark brown, apical pore not seen. Peridium comprising 2-3 layers of brown cells of textura angularis, conidiophores and conidiogenous cells not seen. Conidia subglobose to ellipsoidal, 1-celled, hyaline to brown, guttulate, smooth-walled.

Type species - Cleistosphaera macrostegia Syd. \& P. Syd.

Notes - The genus Cleistosphaera was introduced by Sydow \& Sydow (1916) with the type species $C$. macrostegia. The genus is characterized by its superficial ascomata, aerial mycelium with hyphopodia and aseptate hyaline ascospores. The type species $C$. macrostegia was found associated with a coelomycetous asexual morph and its conidia are phoma-like, which differentiates it from all genera in Perisporiopsidaceae which are hyphomycetous. Cleistosphaera shares common features with taxa in Botryosphaeriaceae in asci and ascospores. Cleistosphaera macrostegia differs from Botryosphaeriaceae in having mycelium with hyphopodia. The genus contains two species epithets in Cleistosphaera, C. leguminis Bat. \& A.A. Silva and C. macrostegia Syd. \& P. Syd. (Index Fungorum 2017).

Cleistosphaera macrostegia Syd. \& P. Syd. [as 'macrostegiae'] Annls mycol. (1916)

Index Fungorum number: IF161307; Facesoffungi number: FoF03670

Fig. 59

Parasitic or saprobic on leaves of Piptadenia sp. Sexual morph: Ascomata 102-116 $\mu \mathrm{m}$ diameter $\times 100-120 \mu \mathrm{m}$ high, superficial, grouped or solitary, uniloculate, globose to subglobose, with a subiculum, dark brown, with apical pore, with 5-9 $\mu \mathrm{m}$ wide, branched, septate, dark brown mycelium, hyphopodia $12-15 \mu \mathrm{m}$ wide, subglobose and dark brown. Hamathecium $3.5-5(-8) \mu \mathrm{m}$ wide, comprising sparse, septate, hyaline, pseudoparaphyses with constricted at the septa. Peridium 11-15(-20) $\mu \mathrm{m}$ wide, comprising 2-3 layers of dark brown, 5-10 $\mu \mathrm{m}$ diameter cells of textura angularis. Asci $66-80 \times 26-33 \mu \mathrm{m}(\bar{x}=72 \times 29.5 \mu \mathrm{m}, \mathrm{n}=10), 8$-spored, bitunicate, ovoid to broadly clavate, sessile or with knob-like pedicel, apically thickened and rounded, with small ocular chamber. Ascospores 22-28 $\times 9-11 \mu \mathrm{m}(\bar{x}=25 \times 10 \mu \mathrm{m}, \mathrm{n}=10), 2-3$-seriate, ellipsoid oblong, aseptate, hyaline to pale grey, surrounded by a thin gelatinous sheath, with granular contents, smooth-walled. Asexual morph: coelomycetous associated with Cleistosphaera macrostegia. Pycnidia 75-99.5 $\mu \mathrm{m}$ high $\times 50-80 \mu \mathrm{m}$ diameter, superficial, globose to subglobose, dark brown, apical pore not seen. Peridium 6-9 $\mu \mathrm{m}$ wide, comprising 2-3 layers of brown cells of textura angularis, conidiophores and conidiogenous cells not seen. Conidia $5-6(-7) \times 2-3 \mu \mathrm{m}(\bar{x}=$ $5 \times 3 \mu \mathrm{m}, \mathrm{n}=10$ ), subglobose to ellipsoidal, 1-celled, hyaline to brown, guttulate, smooth-walled.

Material examined - PERU, Amazonas, Rio Acre, Seringal Auristela, on leaves of Piptadenia sp. (Leguminosae), August 1911, E.H.G Ule No. 3502 (S-F10853, holotype).

Coccoideaceae P. Henn. ex Sacc. \& D. Sacc.

Coccoideaceae was redescribed and illustrated by Hyde et al. (2013). This family is characterised by parasitic, superficial, circular or discoid, multi-loculate, dark pigmented, ascostromata immersed at the base, and 1-septate and light pigmented ascospores. Currently, the family comprises two genera Coccoidea and Coccoidella. Further study, fresh collections, isolation and sequencing are required to determine the phylogenetic placement of this family in Dothideomycetes, especially as the type species is yet to be sequenced. 

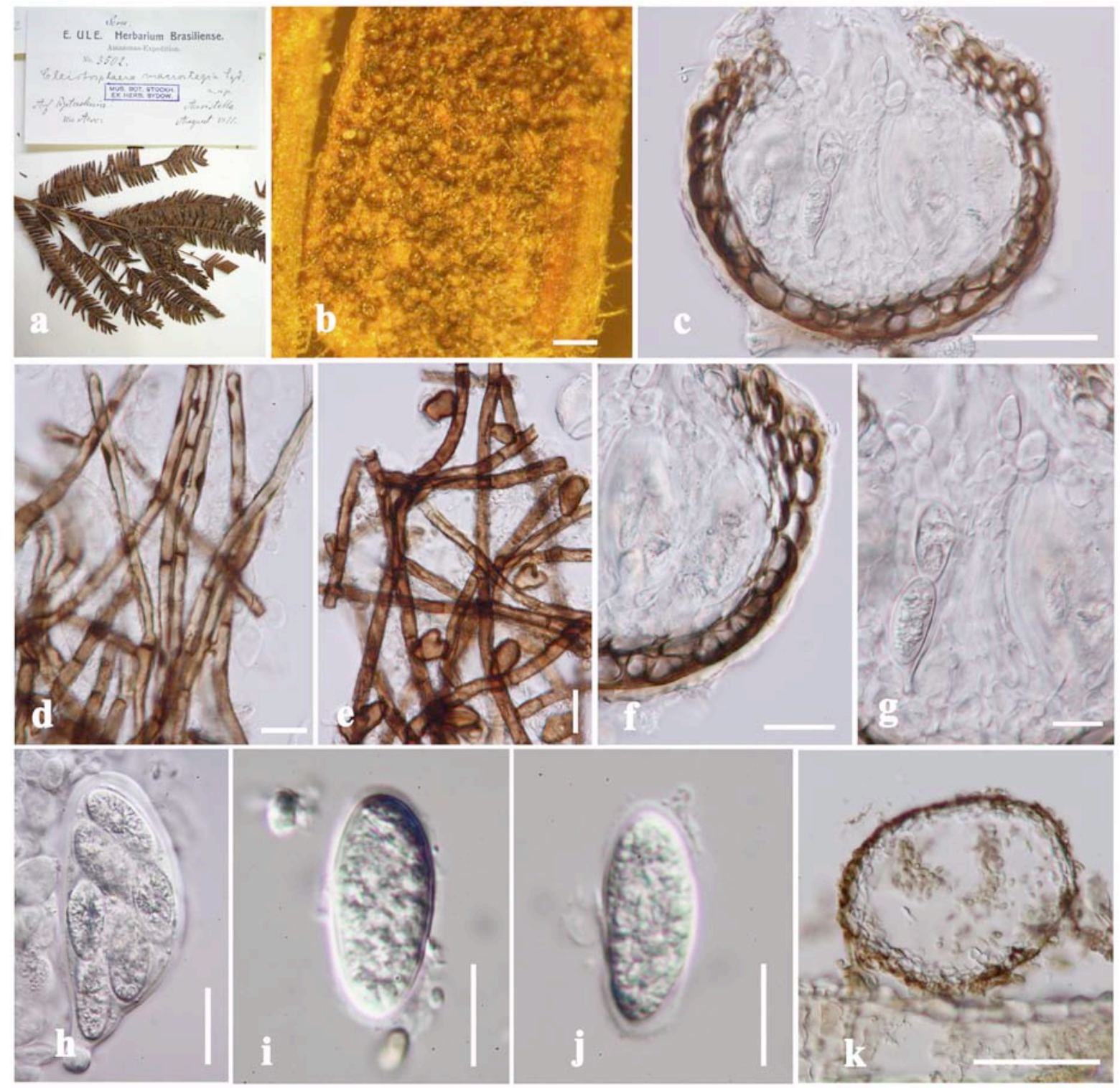

Figure 59 - Cleistosphaera macrostegia (S-F10853, holotype). a Herbarium specimen and habit on leaves. b Appearance of ascomata on leaf surface. c Section of ascoma. d Dark brown mycelium. e Hyphopodia. f Peridium. g Cells of hamathecium in gelatinous matrix. $h$ Ascus. $i, j$ Ascospores. $k$ Pycnidium and conidia. Scale bars: $\mathrm{b}=500 \mu \mathrm{m}, \mathrm{c}, \mathrm{k}=50 \mu \mathrm{m}, \mathrm{d}-\mathrm{f}, \mathrm{h}=20 \mu \mathrm{m}, \mathrm{g}, \mathrm{i}, \mathrm{j}=10 \mu \mathrm{m}$.

Coccoidella Höhn., Sber. Akad. Wiss. Wien, Math.-naturw. K1., Abt. 1 118: 847 [35 repr.] (1909)

Parasitic on living leaves. Sexual morph: Ascostromata superficial, discoid or cupulate, dimidiate-scutate, solitary, gregarious, black, stipitate immersed in host tissue, multi-loculate. Ascomata globose to subglobose, oval, with thickened walls. Peridium comprising dark to black cells of prismatica-angularis, inner layer composed of a gelatinous membrane, lacking pseudoparaphyses. Asci 8-spored, bitunicate, fissitunicate, saccate-oblong to ellipsoidal, sessile, apically thickened, with a small ocular chamber. Ascospores 2-seriate overlapping in the ascus, ellipsoidal-oblong to clavulate, 1-septate, darkened at the septum, hyaline to pale-brown. Asexual morph: Undetermined.

Type species - Coccoidella scutula (Berk. \& M.A. Curtis) Höhn.

Notes - The genus Coccoidella was introduced and placed in the family Coccoideaceae by von Höhnel (1909) and typified by Coccoidella scutula (Berk. \& M.A. Curtis) Höhn. The type species C. scutula shares similar characters with the genus Coccoidea, such as circular or discoid ascostroma, multi-loculate, dark pigmented, bitunicate asci and 1-septate and light pigmented ascospores. Coccoidella is therefore included in the family Coccoideaceae. 
Coccoidella scutula (Berk. \& M.A. Curtis) Höhn., Sber. Akad. Wiss. Wien, Math.-naturw. K1., Abt. 1 118: (1909)

$\equiv$ Dothidea scutula Berk. \& M.A. Curtis 1876

Index Fungorum number: IF121383; Facesoffungi number: FoF03671

Fig. 60

Parasitic on living leaves of Persea palustris (Raf.) Sarg. Sexual morph: Ascostromata 0.80.9(-1) mm diameter, superficial, discoid or cupulate, dimidiate-scutate, solitary, gregarious, black, stipitate immersed in host tissue, multi-loculate. Ascomata $60-68 \mu \mathrm{m}$ diameter $\times 135-157 \mu \mathrm{m}$ high, globose to subglobose, oval, with thickened walls. Peridium 11-18 $\mu \mathrm{m}$ wide, comprising dark to black cells of prismatica-angularis, inner layer composed of gelatinous membrane ca. 7-10 $\mu \mathrm{m}$ wide, lacking pseudoparaphyses. Asci (64-)70-78 $\times(16.5-) 18-22 \mu \mathrm{m}(\bar{x}=72 \times 19 \mu \mathrm{m}, \mathrm{n}=10)$, 8spored, bitunicate, fissitunicate, saccate-oblong to ellipsoidal, sessile, apically thickened, with a small ocular chamber. Ascospores (18-)21-23 x 6-7.5 $\mu \mathrm{m}(\bar{x}=21 \times 7 \mu \mathrm{m}, \mathrm{n}=10)$, 2-seriate overlapping in the ascus, ellipsoidal-oblong to clavulate, 1-septate, slightly constricted and darkened at the septum, hyaline to pale-brown, smooth-walled. Spores can produce germ tubes on slides. Asexual morph: Undetermined.

Material examined - USA, Florida, Green Cove Springs, on living leaves of Persea palustris (Raf.) Sarg. (Lauraceae), undetermined date, G. Martin (BPI 642219, other herbaria: Rehm: Ascomyceten 1669).

Dimeriaceae E. Müll. \& Arx ex Arx \& E. Müll.

Index Fungorum number: IF80704; Facesoffungi number: FoF03672

Parasitic on living leaves, colonies dark brown, mycelium superficial, dark brown, amphigenous. Sexual morph: Ascomata superficial, subglobose, with hyphal appendages, flexuous, cylindrical, septate, dark brown, roughened. Asci 8-spored, bitunicate, fissitunicate, saccate-oblong to ellipsoidal, apically thickened. Ascospores conglobate, ellipsoid-fusiform to subclavate, ends rounded, 1-septate, darkly pigmented at septum, upper cell wider than lower cell, septum supramedian, olivaceous-brown to brown. Asexual morph: hyphomycetous.

Family type - Dimerium (Sacc. \& P. Syd.) McAlpine

Notes - The family Dimeriaceae was introduced by Müller \& von Arx (1962) and validated by von Arx \& Müller (1975). The family has been placed in Dothideales (von Arx \& Müller 1975) and Pleosporales (Barr 1987). Hawksworth \& Eriksson (1986) proposed to conserve the family Dimeriaceae as widely used, while Pseudoperisporiaceae was proposed as the rejected name. Barr (1997) revised three families viz. Epipolaeaceae, Dimeriaceae and Pseudoperisporiaceae. She proposed Pseudoperisporiaceae to the family rank based on earlier name and treated Epipolaeaceae and Dimeriaceae under the family. In this study, we selected D. olivaceum Syd. \& P. Syd. as the type species of Dimerium, Dimeriaceae. Dimerium is characterized by its irregular colonies, dark pigmented ascomata, olivaceous brown to brown ascospores and long conidial hyphomycetes. It is rather atypical of Pseudoperisporiaceae (Hyde et al. 2013). Therefore, the family Dimeriaceae is reinstated to accommodate species in Dimerium.

\section{Dimerium (Sacc. \& P. Syd.) McAlpine, Proc. Linn. Soc. N.S.W. 28: 98 (1903)}

$\equiv$ Dimerosporium subgen. Dimerium Sacc. \& P. Syd. 1902

Parasitic on living leaves, colonies dark brown, mycelium superficial, dark brown, amphigenous. Sexual morph: Ascomata superficial, subglobose, with hyphal appendages, flexuous, cylindrical, septate, dark brown, roughened. Asci 8-spored, bitunicate, fissitunicate, saccate-oblong to ellipsoidal, apically thickened. Ascospores conglobate, ellipsoid-fusiform to subclavate, ends rounded, 1-septate, constricted at the septa and dark pigmented, upper cell wider than lower cell, septum supramedian, olivaceous brown to brown. Asexual morph: hyphomycetous, Heterosporiopsis sp. Colonies large, superficial, epiphyllous, dark brown, with numerous mycelium, brown to darkly brown hyphae, scattered, with brown to dark brown hyphopodia-like structures. Conidia formed on superficial hyphae, irregular, subglobose to elongate ellipsoidal, basal cell wider, multi-septate, dark brown, rough-walled. 


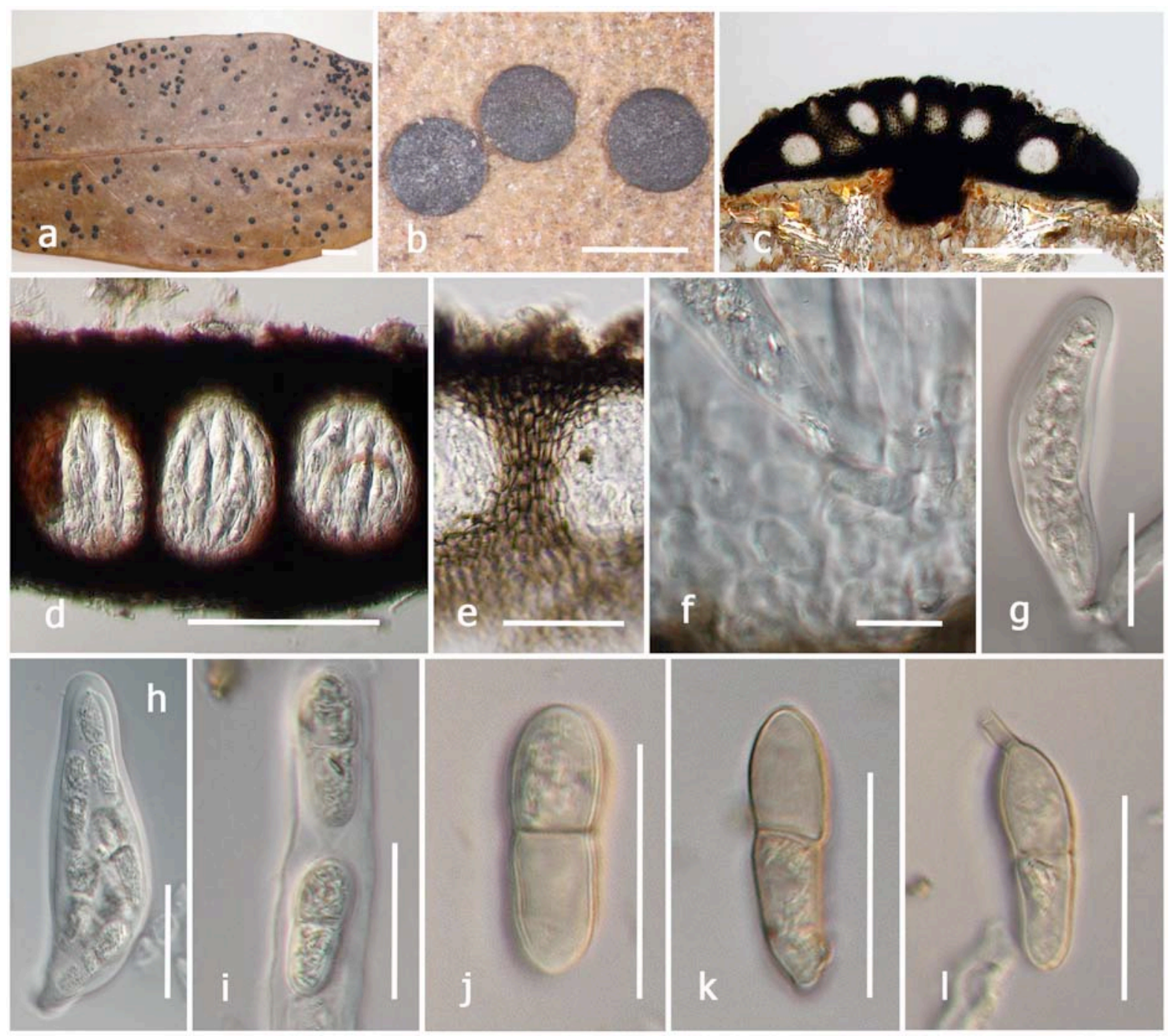

Figure 60 - Coccoidella scutula (BPI 642219). a Herbarium specimen and habit on leaf. b Appearance of ascostromata on leaf surface. c Section of ascostroma. d, e Close up of ascomata and peridium cells. f Gelatinous tissues. $\mathrm{g}$, $\mathrm{h}$ Asci. $\mathrm{i}-1$ Ascospores. Scale bars: $\mathrm{a}=$ Label, $\mathrm{b}=1 \mathrm{~mm}, \mathrm{c}=$ $200 \mu \mathrm{m}, \mathrm{d}=100 \mu \mathrm{m}, \mathrm{e}=50 \mu \mathrm{m}, \mathrm{f}=10 \mu \mathrm{m}, \mathrm{g}-1=20 \mu \mathrm{m}$.

Type species - Dimerium olivaceum Syd. \& P. Syd.

Notes - Currently, the type species of the genus Dimerium remains unresolved. Dimerium was introduced by Saccardo \& Sydow (1902) as a subgenus of Dimerosporium. Subsequently, McAlpine (1903) raised Dimerium to generic rank without designating a generic type. He separated it from Dimerosporium based on the coloured ascospores. Clements \& Shear (1931) selected Dimerium pulveraceum (Speg.) Theiss. as the lectotype species and several mycologists followed this (Hansford 1946, Müller \& von Arx 1962, von Arx \& Müller 1975, Eriksson \& Hawksworth 1993). Hughes (1993) restudied Dimerosporium pangerangense, D. ctenotrichum, D. tasmanicum and D. occultum and transferred them to other genera, while Dimerium pulveraceum was not included in this group. Therefore, Dimerium olivaceum Syd. \& P. Syd. was considered and described as the type species (Hughes 1993). Barr (1997) disagreed with Hughes (1993) in assigning D. olivaceum as the type species, because of lack of hypostromata and lack of internal haustoria. The feature of ascospores and aparaphysate ascomata is similar to members of Asterinales. Thus, D. tasmanicum was considered as the lectotype species of Dimerium. Furthermore, D. tasmanicum should be used as an earlier generic name for species transferred to Maireella. Morphologically, Dimerium tasmanicum is characterized by a subcuticular plate, ascostromata, multi-loculate, obclavate to cylindric asci and clavate, 1-septate, light brown 
ascospores (Hansford 1954). The genus Maireella is characterized by superficial, uniloculate, solitary, globose to subglobose, ostiole and papillate ascomata ( $\mathrm{Li}$ et al. 2014). Barr (1997) mentioned that Maireella should be included in the family Coccoideaceae, rather than the family Venturiaceae. Hansford (1946, 1954) described many species of Dimerium as mycoparasitic on other leaf fungi, with superficial ascomata, lacking setae, seated on mycelium, with globose to ovate-conoid exhyphopodia, which differs from the characters of D. tasmanicum. According to Hughes (1993), D. olivaceum seems appropriate for the type species. Thus, we provide a photo plate and brief description of D. olivaceum referenced from Hughes (1993). The type species $D$. olivaceum shows distinctive morphological features from the type species Lasiostemma melioloides, Pseudoperisporiaceae and is connected with a hyphomycetous asexual morph (Hughes \& Seifert 1998). In this study, we place Dimerium in the family Dimeriaceae.

Dimerium olivaceum Syd. \& P. Syd., Annls mycol. 2(2): 169 (1904)

Index Fungorum number: IF234107; Facesoffungi number: FoF03673

Figs 61-63

Parasitic on living leaves of Cynocton nummulariifolium (Hook. \& Arn.) Decne., colonies dark brown, mycelium superficial, amphigenous. Sexual morph: Ascomata (92-)156-194(-250) $\mu \mathrm{m}$ diameter, superficial, subglobose, flexuous, cylindrical, 3-4.5 $\mu \mathrm{m}$ wide, septate, dark brown, roughened, with apical pore $c a$. $30 \mu \mathrm{m}$ diameter. Asci 50-63 $\times(9-) 11-14 \mu \mathrm{m}(\bar{x}=56 \times 12 \mu \mathrm{m}, \mathrm{n}=$ 10), 8-spored, bitunicate, fissitunicate, saccate-oblong to ellipsoidal, apically thickened. Ascospores 11-16 $\times 5-7 \mu \mathrm{m}(\bar{x}=13 \times 6 \mu \mathrm{m}, \mathrm{n}=20)$, conglobate, ellipsoid, upper cell wider, ends rounded, $1-$ septate, constricted at the septa and darkly pigmented, upper cell wider than lower cell, septum supramedian, olivaceous brown to brown, smooth-walled. Asexual morph: hyphomycetous, Heterosporiopsis sp. Colonies large, superficial, epiphyllous, dark brown, with dense mycelia, brown to dark brown, with hyphopodia-like structures, 5-5.5 $\mu \mathrm{m}$ diameter, brown to dark brown, Conidia 28-64 × 6-9 $\mu \mathrm{m}$, formed on superficial hyphae, irregular, subglobose to elongate ellipsoidal, basal cell wider, 3-5-septate, dark brown, rough-walled.

Material examined - CHILE, Anden bei Villarica, on living leaves of Cynoctonum nummulariaefolium (Hook. \& Arn.) Decne. (Asclepiadaceae), February 1897, F.W. Neger (SF11956, holotype).

Dysrhynchisceae Boonmee \& K.D. Hyde, fam. nov.

Index Fungorum number: IF553829; Facesoffungi number: FoF03674

Saprobic on dead leaves. Sexual morph: Ascomata superficial, globose to subglobose, dark brown, solitary, aggregated, pore central, with a protruding synnematous neck, comprised of tightly compacted hyphae, sparse superficial mycelium with hyphopodia, brown to dark brown, with partially immersed mycelia, lacking setae, lacking pseudoparaphyses. Peridium membranous, comprising brown cells of textura angularis. Asci 8-spored, bitunicate, broadly obclavate to ovoid, sessile, apically thickened. Ascospores multi-seriate, conglobate, ellipsoidal, clavate to obpyriform, hyaline to light brown. Asexual morph: hyphomycetous.

Family type - Dysrhynchis Clem.

Notes - The family Dysrhynchisceae is introduced based on Dysrhynchis Clem. The family is characterized by a long necked ascomata, with hyphomycetous conidia produced at the apex of the ascomata, mycelium with hyphopodia, lack of pseudoparaphyses, broadly obclavate to ovoid asci, and conglobate, ellipsoid, 1-septate, hyaline to light brown ascospores. Therefore, Dysrhynchisceae can be separated from the families Capnodiaceae and Perisporiopsidaceae. Dysrhynchisceae differs from Capnodiaceae and Perisporiopsidaceae in having sexual ascomata protruding synnematous necks, mycelium with hyphopodia, transversally uni-septate ascospores and a hyphomycetous asexual morph. Capnodiaceae is characterized by black mycelium on the host surface, lack of hyphopodia, lack of necks, multi-septate or muriform ascospores and a coelomycetous asexual morph comprising pycnidium with long necks and ellipsoidal, one-celled conidia (see in the genus Phragmocapnias, Chomnunti et al. 2011). In addition, several species in Capnodiaceae are commonly associated with the honeydew produced by insects such as aphids 
(Chomnunti et al. 2011). We therefore introduce the new family Dysrhynchisceae, because it has a suite of characters that differ from other families of Dothideomycetes.

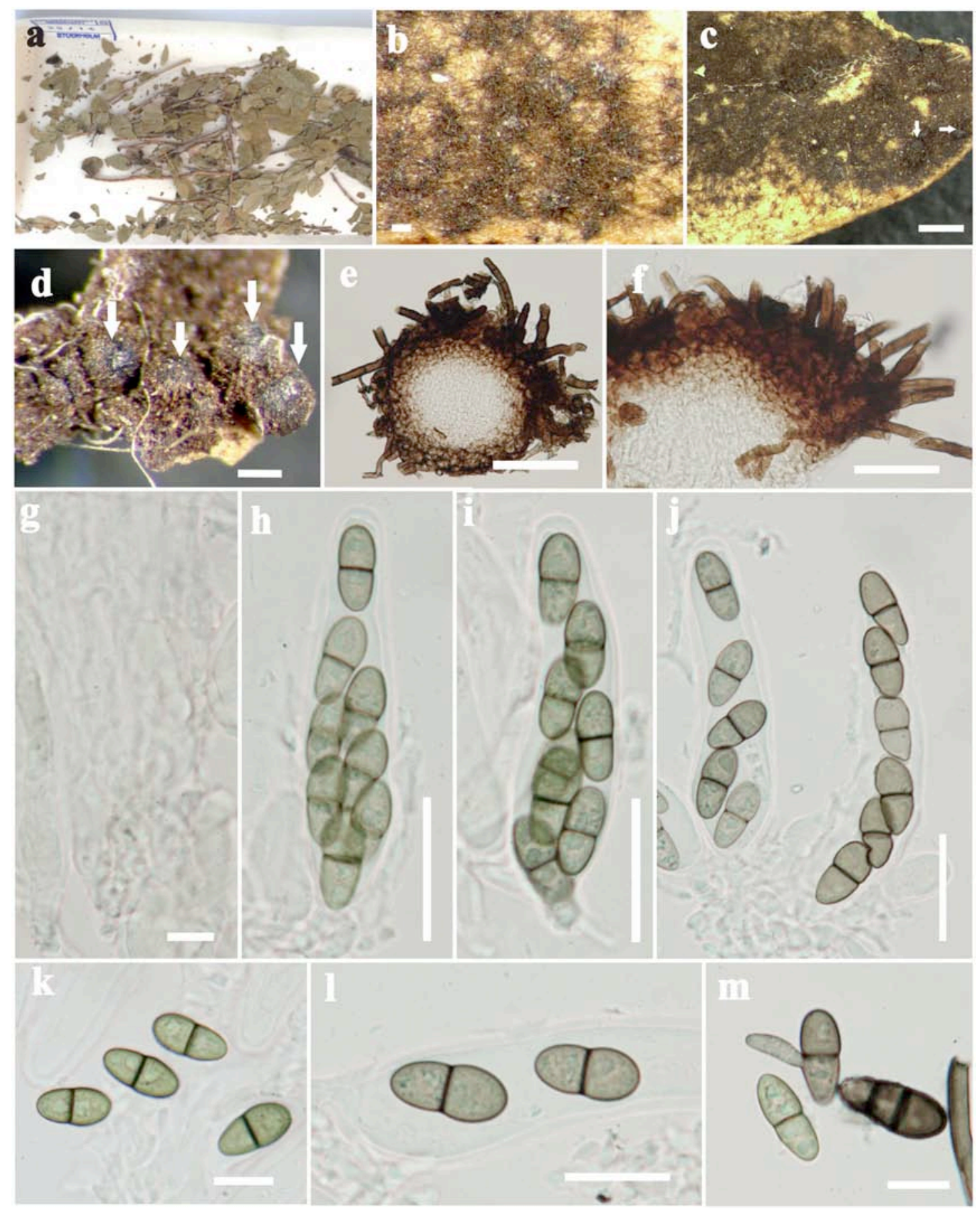

Figure 61 - Dimerium olivaceum (S-F11956, holotype). a Herbarium specimen and habit on leaves. b, c Appearance of colonies on leaves surface. $d$ Ascomata, marked by arrows e Section of ascoma. f Peridium. g Hamathecium comprising pseudoparaphyses. $\mathrm{h}-\mathrm{j}$ Asci. $\mathrm{k}, 1$ Ascospores. $\mathrm{m}$ Germ tube of ascospore. Scale bars: $b=100 \mu \mathrm{m}, \mathrm{c}=500 \mu \mathrm{m}, \mathrm{d}=200 \mu \mathrm{m}, \mathrm{e}=50 \mu \mathrm{m}, \mathrm{f}, \mathrm{h}-\mathrm{j}=20$ $\mu \mathrm{m}, \mathrm{g}, \mathrm{k}-\mathrm{m}=10 \mu \mathrm{m}$.

Dysrhynchis Clem., Gen. fung. (Minneapolis): 3(1909)

Saprobic on dead leaves. Sexual morph: Ascomata superficial, globose to subglobose, dark brown, solitary, aggregated, pore central, with a protruding synnematous neck, comprised of tightly compacted hyphae, sparse superficial mycelium with hyphopodia, brown to dark brown, partially immersed mycelia, lacking setae, lacking pseudoparaphyses. Peridium membranous, comprising 


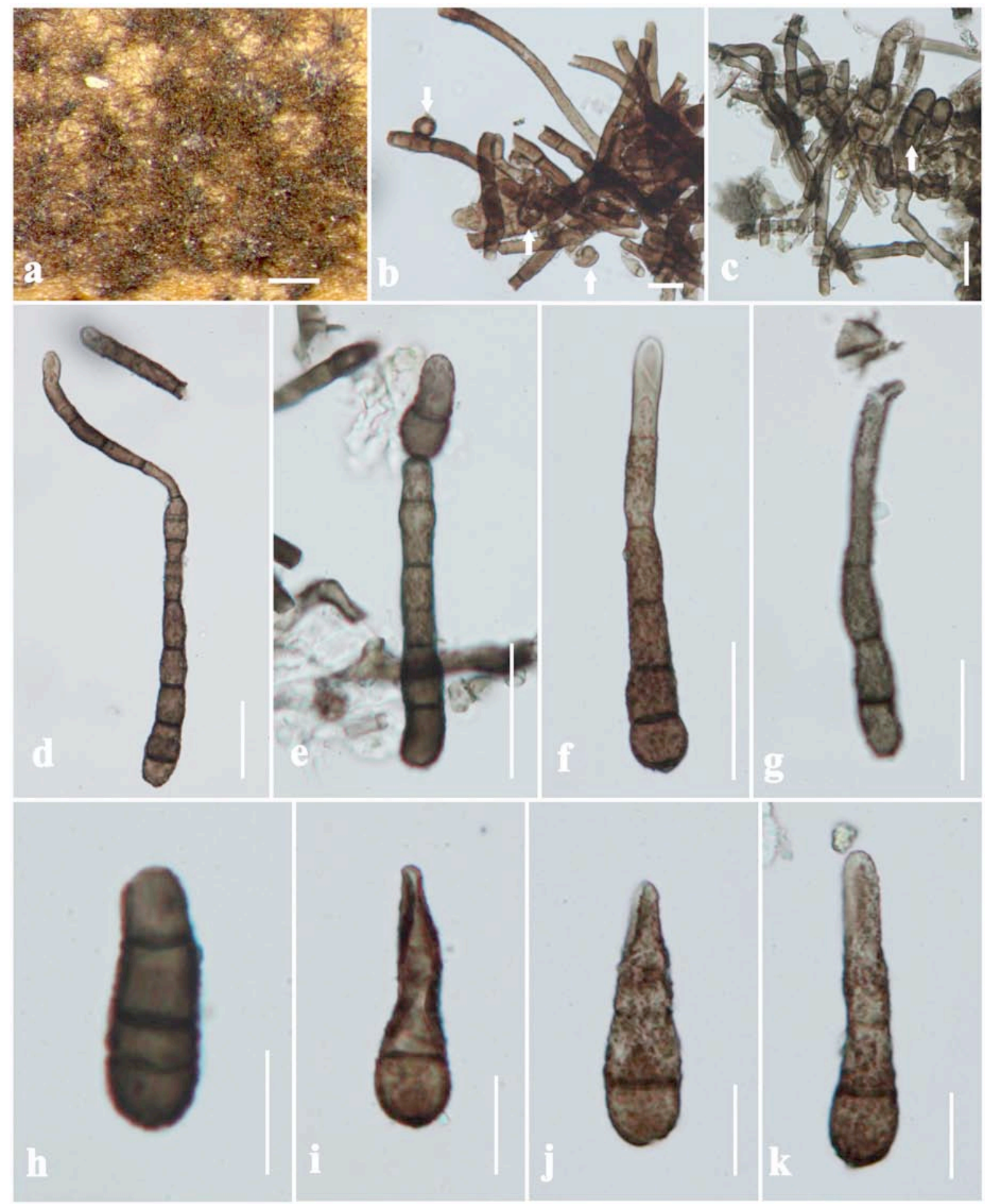

Figure 62 - Dimerium olivaceum (S-F11956, holotype). a Fungal colonies on leaf surface. b, c Mycelium with hyphopodia-like structures and conidia, marked by arrows. $\mathrm{d}-\mathrm{g}$ Conidiophores and different stages of developing conidia. $h-k$ Conidia. Scale bars: $a=200 \mu \mathrm{m}, b=50 \mu \mathrm{m}, \mathrm{c}=10 \mu \mathrm{m}$, $\mathrm{d}-\mathrm{g}=20 \mu \mathrm{m}, \mathrm{h}-\mathrm{k}=10 \mu \mathrm{m}$.

brown cells of textura angularis. Asci 8-spored, bitunicate, broadly obclavate to ovoid, sessile, apically thickened. Ascospores multi-seriate, conglobate, ellipsoidal, clavate to obpyriform, upper cell wider, septate, hyaline to light brown. Asexual morph: hyphomycetous, with synnemata. Conidiophores and conidiogenous cells were not observed. Conidia cylindrical oblong to fusiform, multi-septate, constricted at the septa, brown, smooth-walled.

Type species - Dysrhynchis pulchella (Sacc.) Clem. 


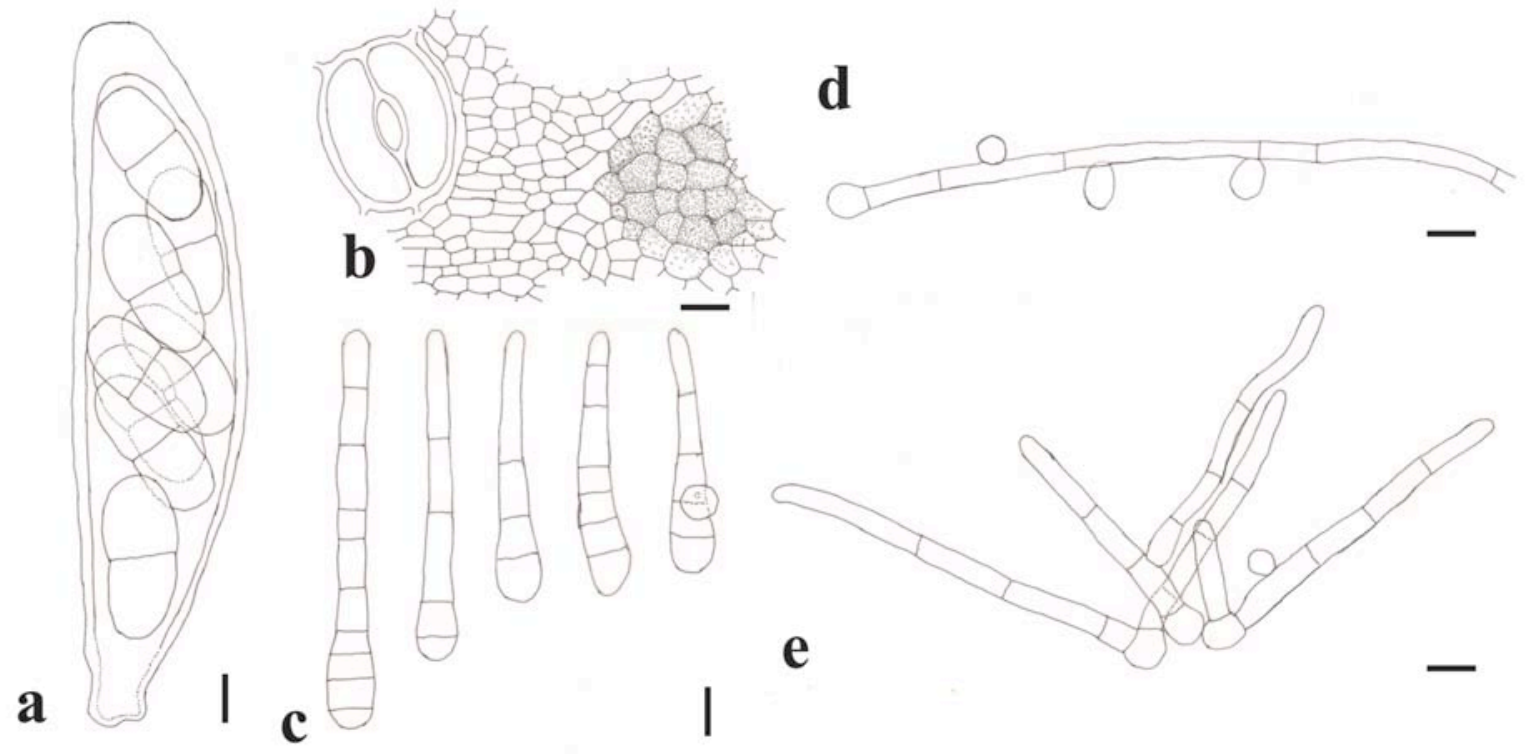

Figure 63 - Dimerium pulveraceum (redrawn from Hughes 1993, Fig. 134). a. Ascus with ascospores. b. Subcuticular hyphae. c Conidia. d, e Hyphae with forming conidia. Scale bars: a-e = $10 \mu \mathrm{m}$.

Notes - Clements (1909) introduced the genus Dysrhynchis without mentioning a type species. Theissen \& Sydow (1917) transferred Henningsomyces (H. pulchellus Sacc, type species) to the family Capnodiaceae based on features of elongated synnematous neck and 1-septate, hyaline to brown spores. Clements \& Shear (1931) treated Dysrhynchis pulchella (三 Henningsomyces pulchellus) as the type species. Hansford (1946) re-examined the type species $H$. pulchellus Sacc. (an earlier name of Dysrhynchis pulchella (Sacc.) Clem.) and noted that this fungus was of doubtful position, and suggested fresh collections were needed for a clear systematic understanding. Müller \& von Arx (1962) revised several genera and synonymized them under Dysrhynchis, i.e. Balladyna amazonica Höhn., B. uncinata Syd. \& P. Syd., Diatrypella palmicola Syd., Meliola oligotricha Mont., Pisomyxa amomi Berk. \& Broome and Rizalia confusa Doidge, and also placed the genus in the family Perisporiopsidaceae. Currently there are seven names listed in Index Fungorum (2017). Perisporiopsidaceae is characterized by superficial mycelium covering the ascomata and multi-septate ascospores. We re-examined the holotype specimen Dysrhynchis pulchella from PAD and compared morphological characters with genera in Capnodiaceae and Perisporiopsidaceae including their asexual morphs and decided both families are mismatched for Dysrhynchis (Hyde et al. 2013, Chomnunti et al. 2011, 2014, Yang et al. 2014, Hongsanan et al. 2015). We therefore exclude the genus Dysrhynchis from Perisporiopsidaceae and introduce the new family Dysrhynchisceae for the genus Dysrhynchis.

Dysrhynchis pulchella (Sacc.) Clem., Gen. fung., Edn 2 (Minneapolis): 253 (1931)

三 Henningsomyces pulchellus Sacc. Syll. fung. (Abellini) 17: 689 (1905)

Index Fungorum number: IF254191; Facesoffungi number: FoF03675

Fig. 64

Saprobic on dead leaves of Byrsonima sericae A. Juss. Sexual morph: Ascomata 77-97(105) $\mu \mathrm{m}$ diameter $\times 76-99(-106) \mu \mathrm{m}$ high $(\bar{x}=92 \times 90 \mu \mathrm{m})$, superficial, globose to subglobose, dark brown, solitary, aggregated, pore central, $20-25 \mu \mathrm{m}$ diameter, with a protruding synnematous neck, comprised of tightly compacted hyphae, 196-323 $\mu \mathrm{m}$ long, sparse superficial mycelium with hyphopodia, 6-8 $\mu \mathrm{m}$ diameter, brown to dark brown, partially immersed mycelia, lacking setae, lacking pseudoparaphyses. Peridium 8-9 $\mu \mathrm{m}$ wide, comprising membranous of brown cells of textura angularis. Asci 40-56 $\times 20-35 \mu \mathrm{m}(\bar{x}=47 \times 24 \mu \mathrm{m}, \mathrm{n}=10), 8$-spored, bitunicate, broadly obclavate to ovoid, sessile, apically thickened. Ascospores $21-33 \times 7-12 \mu \mathrm{m}(\bar{x}=28 \times 10 \mu \mathrm{m}, \mathrm{n}=$ 20), multi-seriate, conglobate, ellipsoidal, clavate to obpyriform, upper cell wider, 1-septate in the 
center or above, constricted at the septum, hyaline to light brown, smooth-walled. Asexual morph: hyphomycetous, with synnemata. Conidiophores and conidiogenous cells not observed. Conidia 20-25 $\mu \mathrm{m} \times 4-5 \mu \mathrm{m}$, cylindrical oblong to fusiform, 2-3-septate, constricted at the septa, brown, smooth-walled.

Material examined - BRAZIL, Rio de Janeiro, Mauá, on dead leaves of Byrsonima sericae A. Juss. (Malpighiaceae), 21 July 1899, E.H.G. Ule, Mycotheca brasiliensis no. 71 (PAD, holotype).

Hyalomeliolinaceae Boonmee \& K.D. Hyde fam. nov.

Index Fungorum number: IF553830; Facesoffungi number: FoF03676

Parasitic on living leaves. Sexual morph: Colonies form on lower surface of leaves, black, subcircular with outwardly radiating mycelium, with hyphae that are long hairy, flexible, dark brown to black, densely, fluffy, partially erect, unbranched, and septate. Ascomata superficial, globose to subglobose, black, seated on dark hyphae, covered by dense hyphae, superficial mycelium, unbranched, septate, dark to black. Peridium comprising dark brown to black cells of textura angularis. Hamathecium comprising elongate-filiform, septate, unbranched, filamentous pseudoparaphyses, extending over asci, constricted at the septa. Asci 8-spored, bitunicate, fissitunicate, saccate-oblong to ellipsoidal, sessile, lower median widest, with small ocular chamber. Ascospores 2-seriate, ellipsoid-fusiform, ends narrow, multi-septate, pigmented. Asexual morph: Undetermined.

Notes - The new family Hyalomeliolinaceae is introduced to accommodate three species in Hyalomeliolina. Morphologically, Hyalomeliolina differs from the type species in Perisporiopsidaceae in having numerous hyphal colonies and saccate-oblong to ellipsoidal, up to 3-septate, light to dark pigmented ascospores. According to its characteristics, Hyalomeliolina can be separated from Perisporiopsidaceae and is raised to familial rank. We introduce the new family Hyalomeliolinaceae, because it has a suite of characters that differ from other families of Dothideomycetes.

Hyalomeliolina F. Stevens, Illinois Biol. Monogr. (Urbana) 8(no. 3): 27 (1923)

Parasitic on living leaves. Sexual morph: Colonies formed on lower surface of leaves, black, subcircular with outwardly radiating mycelium, with hyphae that are long hairy, flexible, dark brown to black, densely, fluffy, partial erect, unbranched, and septate. Ascomata superficial, globose to subglobose, black, seated on dark hyphae, covered by dense hyphae, superficial mycelium, unbranched, septate, dark to black. Peridium comprising dark brown to black cells of textura angularis. Hamathecium comprising ca. $2 \mu \mathrm{m}$ wide, elongate-filiform, septate, unbranched, hyaline, filamentous pseudoparaphyses, extending over the asci, slightly constricted at the septa. Asci 8-spored, bitunicate, fissitunicate, saccate-oblong to ellipsoidal, sessile, lower median cell widest, with small ocular chamber. Ascospores 2-seriate, ellipsoid-fusiform, ends narrow, initially 1-septate, becoming 3-septate at maturity, light brown, olivaceous brown to dark brown at maturity. Asexual morph: Undetermined.

Type species - Hyalomeliolina guianensis F. Stevens

Notes - Stevens (1923) established the genus Hyalomeliolina to accommodate a species having superficial ascomata, with mycelia lacking hyphopodia. The genus is typified by H. guianensis Stevens and was placed in family Perisporiaceae. Sivanesan (1987) revised the genus Hyalomeliolina and transferred it to Parodiopsidaceae. Petrak (1953) synonymized three genera viz. Leptomeliola Hohn, Meliolinopsis Beeli and Phaeophragmeriella Hansf. under Hyalomeliolina. Hughes (1993) redescribed several genera closely related to Meliolina and introduced the family Meliolinaceae, also, excluding several genera and species which included Hyalomeliolina. Currently three species are listed in the genus in Index Fungorum (2017). Kirk et al. (2008) indexed Hyalomeliolina in the family Pseudoperisporiaceae. Lumbsch \& Huhndorf (2010) placed this genus in family the Parodiopsidaceae and commented on its uncertain taxonomic position. Based on morphological characters this genus can be placed in the new family Hyalomeliolinaceae. 


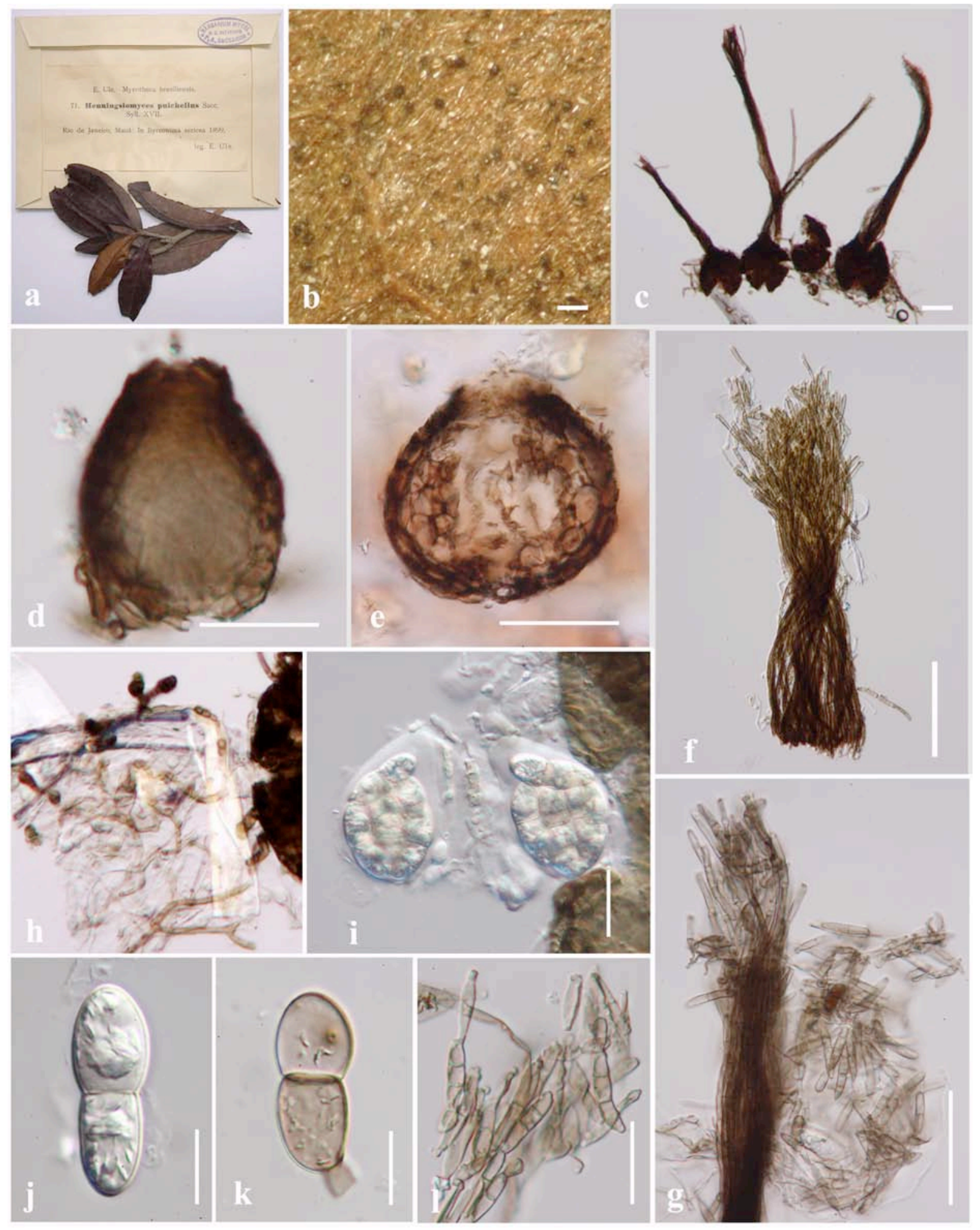

Figure 64 - Dysrhynchis pulchella (PAD No. 71, holotype). a Herbarium specimen and habit on leaves. b Appearance of ascomata on leaf surface. c Squash mount of ascomata with protruding synnematous necks. d, Section of ascoma. e Peridium. f Bulbous base of a synnema through the apex. g Synnema with apical conidia. h Hyphopodia and appressoria. i Asci. j, k Ascospores (Fig. k Germ tube of ascospore). 1 Conidia. Scale bars: $b-d, f, g=50 \mu \mathrm{m}, \mathrm{e}, \mathrm{i}, \mathrm{l}=20 \mu \mathrm{m}, \mathrm{h}, \mathrm{j}, \mathrm{k}=10 \mu \mathrm{m}$.

Hyalomeliolina guianensis F. Stevens, Illinois Biol. Monogr. (Urbana) 8(no. 3): 27 (1924) [1923] Index Fungorum number: IF266643; Facesoffungi number: FoF03677 Fig. 65 Parasitic on living leaves of Licania sp. Sexual morph: Colonies 2.5-3.5 mm diameter, formed on lower surface of leaves, black, subcircular with outwardly radiating mycelium, with hyphae that are 
long hairy, flexible, dark brown to black, densely, fluffy, partial erect, unbranched, and septate. Ascomata 193-216 $\mu \mathrm{m}$ diameter $\times 189-210 \mu \mathrm{m}$ high, superficial, globose to subglobose, black, seated on dark hyphae, covered by dense hyphae, superficial mycelium, unbranched, septate, dark to black. Peridium 23-27 $\mu \mathrm{m}$ wide, comprising dark brown to black cells of textura angularis. Hamathecium comprising ca. $2 \mu \mathrm{m}$ wide, elongate-filiform, septate, unbranched, hyaline, filamentous pseudoparaphyses, extending over the asci, slightly constricted at the septa. Asci (86) $98-113(-127.5) \times(28-) 31-34 \mu \mathrm{m}(\bar{x}=103 \times 32 \mu \mathrm{m}, \mathrm{n}=10), 8$-spored, bitunicate, fissitunicate, saccate-oblong to ellipsoidal, sessile, lower median cell widest, with small ocular chamber. Ascospores 35-44(-48) $\times 11-15 \mu \mathrm{m}(\bar{x}=41 \times 12.5 \mu \mathrm{m}, \mathrm{n}=10)$, 2-seriate, ellipsoid-fusiform, ends narrow, initially 1 -septate, becoming 3 -septate at maturity, constricted at the median septum, light brown, olivaceous brown to dark brown at maturity, smooth-walled. Asexual morph: Undetermined.

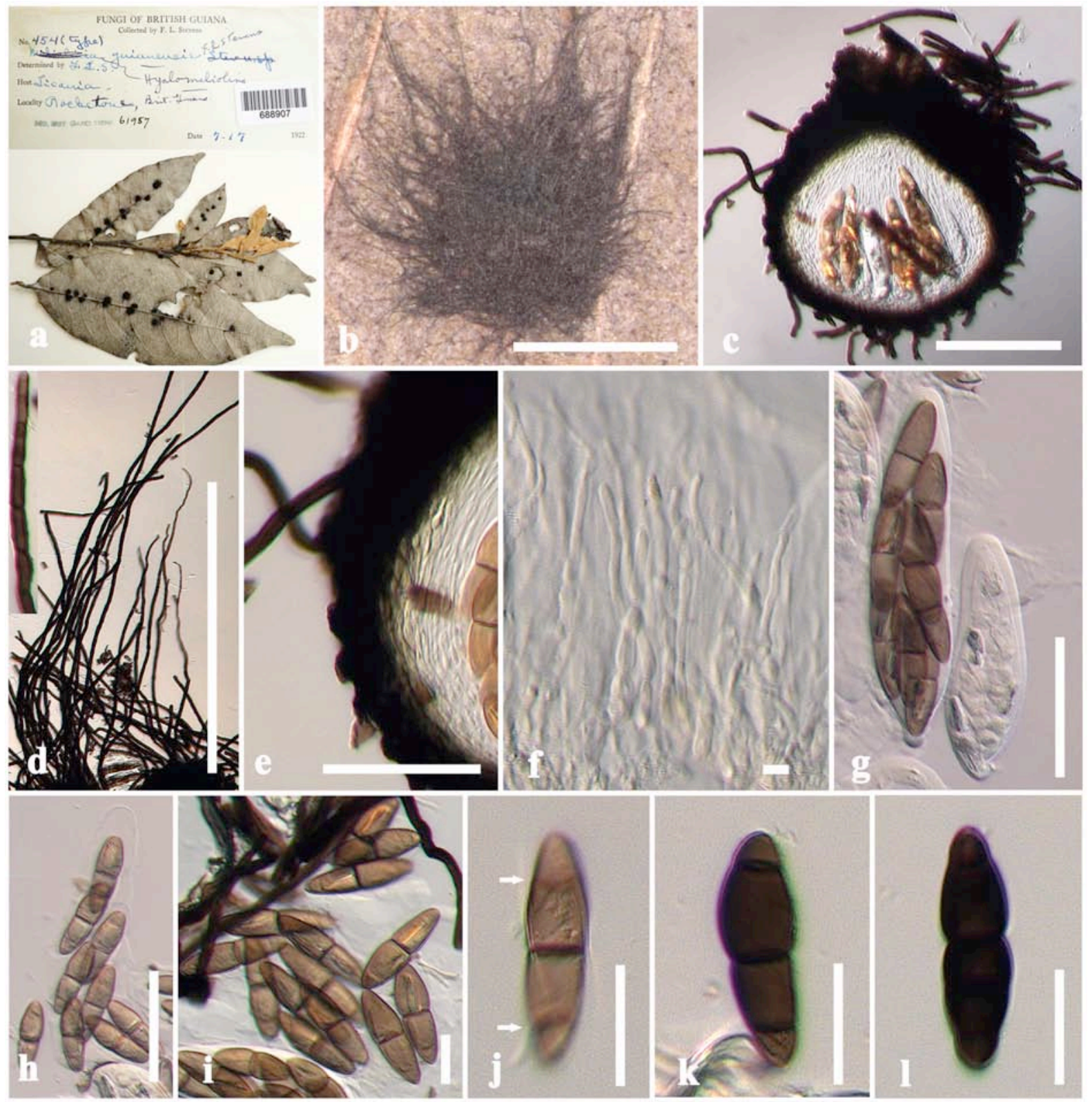

Figure 65 - Hyalomeliolina guianensis (BPI688907, holotype). a Herbarium specimen and habit on leaves. b Ascomata covered by hyphae on leaf surface. c Section of ascoma. d Hairy hyphae. e Peridium. f Pseudoparaphyses. g, h Asci. i-1 Ascospores. Scale bars: $\mathrm{b}=2 \mathrm{~mm}, \mathrm{c}=100 \mu \mathrm{m}, \mathrm{d}=$ $500 \mu \mathrm{m}, \mathrm{e}=50 \mu \mathrm{m}, \mathrm{f}=5 \mu \mathrm{m}, \mathrm{g}, \mathrm{h}=50 \mu \mathrm{m}, \mathrm{i}-1=20 \mu \mathrm{m}$. 
Material examined - GUYANA (= British Guiana), Rockstone, on living leaves of Licania Aubl. (Chrysobalanaceae), 17 July 1922, F.L. Stevens No. 454 (BPI688907, holotype).

Lizoniaceae Boonmee \& K.D. Hyde, fam. nov.

Index Fungorum number: IF553831; Facesoffungi number: FoF03678

Parasitic, foliicolous on perichaetial leaves of living mosses. Sexual morph: Ascomata superficial, solitary or in groups, unilocular, globose to subglobose, black, with obscure ostiole, superficial mycelium absent. Peridium comprising 3-4 layers of brown cells of textura angularis. Hamathecium comprising numerous, long cylindrical, unbranched, septate, pseudoparaphyses. Asci 8-spored, bitunicate, cylindric-clavate, sessile or with short pedicel, apex rounded. Ascospores 1-2seriate, ellipsoidal-fusiform, upper cell broader than basal cell, 1-septate, brown. Asexual morph: Undetermined.

Family type - Lizonia (Ces. \& De Not.) De Not.

Notes - The new family Lizoniaceae is introduced to accommodate the genus Lizonia based on its bryophilous characteristic. The family is characterized by superficial, sphaerical, black ascomata, bitunicate asci, pseudoparaphyses and septate, hyaline to coloured ascospores. Phylogenetically, Lizonia clustered in a strongly supported clade among the families in the order Pleosporales (Fig. 1b in Stenroos et al. 2010). We introduce the new family Lizoniaceae, because it has a suite of characters that differ from other families of Dothideomycetes.

Lizonia (Ces. \& De Not.) De Not., Sfer. Ital.: 72 (1863)

Parasitic, foliicolous on perichaetial leaves of living mosses. Sexual morph: Ascomata superficial, solitary or in groups, unilocular, globose to subglobose, black, with obscure ostiole, superficial mycelium absent. Peridium comprising 3-4 layers of brown cells of textura angularis. Hamathecium comprising numerous, long cylindrical, unbranched, septate, hyaline pseudoparaphyses. Asci 8-spored, bitunicate, cylindric-clavate, sessile or with short pedicel, apex rounded. Ascospores 1-2-seriate, ellipsoidal-fusiform, upper cell broader than basal cell, 1-septate. Asexual morph: Undetermined.

Type species - Lizonia empirigonia (Auersw.) De Not.

Notes - Lizonia was formally established at the generic rank by De Notaris (Cesati \& De Notaris 1863) from the subgenus Cucurbitaria, which is typified by Lizonia empirigonia (Ces. \& De Not.) De Not. (earlier named Sphaeria emperichaetia Auersw. and Cucurbitaria emperigonia Ces. \& De Not.). The genus has been placed in the families Cucurbitariaceae, Sphaeriaceae, Dimeriaceae and Parodiellaceae by various authors (Cesati \& De Notaris 1863, Hansford 1946, von Arx and Müller 1975, Döbbeler 1978, Barr 1987, Eriksson \& Hawksworth 1993). Lizonia is presently placed in the family Pseudoperisporiaceae on the basis of its bryophilous habit, superficial ascomata, bitunicate asci and 1-septate, hyaline to pigmented ascospores (Hawksworth et al. 1995, Barr 1997, Döbbeler 2003, Barr 2009, Lumbsch \& Huhndorf 2010, Hyde et al. 2013, Buck 2016). Stenroos et al. (2010) provided phylogenetic studies on L. sexangularis and showed this species to cluster with Didymella in the order Pleosporales with good support. The genus Lizonia shares common characters with several genera in Pleosporales such as parasitic, superficial, globose to subglobose, black ascomata, lacking setae, bitunicate asci, pseudoparaphyses and septate, hyaline to coloured ascospores, but it differs in its bryophilous habit. The genus is therefore treated in its family Lizoniaceae in the order Pleosporales (Stenroos et al. 2010, Döbbeler \& Hertel 2013).

Lizonia empirigonia (Ces. \& De Not.) De Not. [as emperigonia], Sfer. Ital.: 72 (1863)

$\equiv$ Cucurbitaria emperigonia Ces. \& De Not., Comm. Soc. crittog. Ital. 1(fasc. 3): 215 (1862)

= Sphaeria emperigonia Auersw., Klotzschii Herb. Viv. Mycol., Edn 2: no. 850 (1858)

= Sphaeria emperichaetia Auersw., Comm. Soc. crittog. Ital. 1(fasc. 3): 215 (1862)

Index Fungorum number: IF145497; Facesoffungi number: FoF03679

Figs 66, 67 
Parasitic, foliicolous on perichaetial leaves of living mosses of Polytrichum commune Hedw. Sexual morph: Ascomata 211-249 $\mu \mathrm{m}$ diameter $\times 256.5-264 \mu \mathrm{m}$ high, superficial, solitary or in groups, unilocular, globose to subglobose, black, with obscure ostiole, superficial mycelium absent. Peridium (16-)20-23 $\mu \mathrm{m}$ wide, comprising 3-4 layers of brown cells of textura angularis. Hamathecium (2.5-)3-4.5 $\mu \mathrm{m}$ wide, comprising numerous, long cylindrical, unbranched, septate, hyaline pseudoparaphyses. Asci 113-164 × 20-27.5 $\mu \mathrm{m}(\bar{x}=131 \times 24 \mu \mathrm{m}, \mathrm{n}=20)$, 8-spored, bitunicate, cylindric-clavate, sessile or with short pedicel, apex rounded. Ascospores 33.5-45 $\times 9$ $11.5 \mu \mathrm{m}(\bar{x}=38.5 \times 10.5 \mu \mathrm{m}, \mathrm{n}=20), 1-2$-seriate, ellipsoidal-fusiform, upper cell broader than basal cell, 1-septate, slightly constricted at the septum, brown, smooth-walled. Asexual morph: Undetermined.

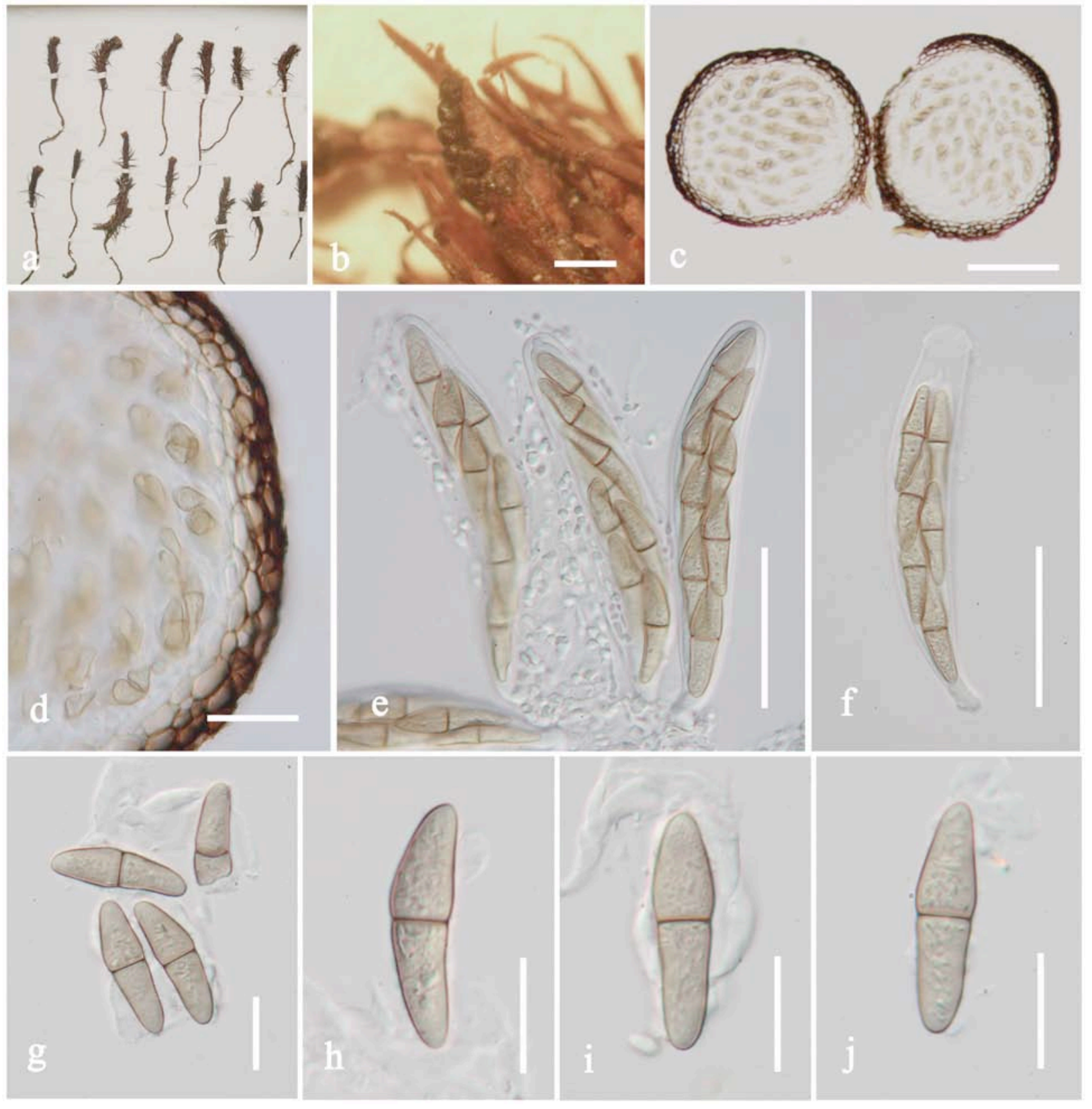

Figure 66 - Lizonia emperigonia (PC 0084487). a Herbarium specimen and habit on leaves. b Appearance of ascomata on leaf surface. c Section of ascomata. c Peridium. e Pseudoparaphyses. $f$ Asci. g-j Ascospores. Scale bars: $\mathrm{b}=500 \mu \mathrm{m}, \mathrm{c}=100 \mu \mathrm{m}, \mathrm{d}, \mathrm{g}-\mathrm{j}=20 \mu \mathrm{m}, \mathrm{e}, \mathrm{f}=50 \mu \mathrm{m}$.

Material examined - ITALY, Lugano, on peduncle of Polytrichum commune Hedw. (Polytrichaceae), August 1848, V. Cesati (in Rabenh. Herb. Mycol. I. no. 850 sub Sphaeria 
emperigonia), PC0084487; GERMANY, Rheinland -Pfalz: near Mappen Nassoviae, Autumn, Fuckel, in Rabenhorst, Fungi europaei, in the syllvaticis swamps between the valley, in Fuckel, Fungi rhenani, Nr. 891, sub Sphaeria emperigonia, on perichaetial leaves of flowers of Polytrichum commune, in B collection under numbers (B 70 0014161, B 7014161 and B 700014163 , type not mentioned).

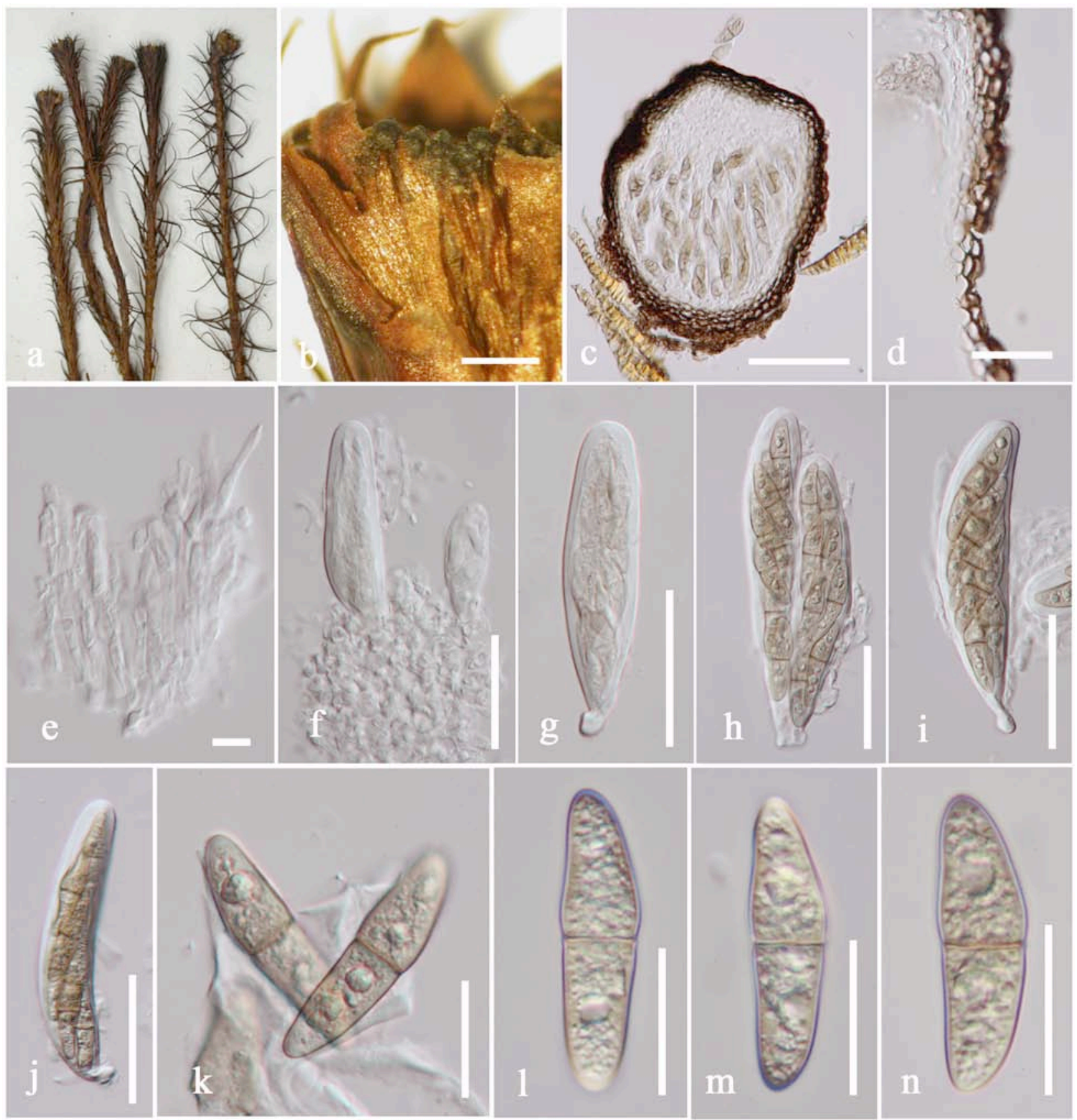

Figure 67 - Lizonia emperigonia (B 70 0014162). a Herbarium specimen and habit on leaves. b Appearance of ascomata on leaf surface. c Section of ascoma. c Peridium. e Hamathecium texture. f Asci. g-j Ascospores. Scale bars: $\mathrm{b}=500 \mu \mathrm{m}, \mathrm{c}=100 \mu \mathrm{m}, \mathrm{d}=40 \mu \mathrm{m}, \mathrm{e}=10 \mu \mathrm{m}, \mathrm{f}-\mathrm{j}=50 \mu \mathrm{m}, \mathrm{k}-$ $\mathrm{n}=20 \mu \mathrm{m}$.

\section{Massarinaceae Munk}

The genus Semifissispora is placed in the family Massarinaceae based on phylogenetic analysis (Crous et al. 2015). 
Semifissispora H.J. Swart, Trans. Br. mycol. Soc. $78(2)$ : 259 (1982)

Parasitic on surface of dead leaves. Sexual morph: Ascomata immersed and becoming erumpent at maturity, solitary or gregarious, globose to subglobose. Peridium comprising 2 layers of hyaline to dark brown cells of textura angularis, rounded ostiole at the center of mature ascomata. Hamathecium comprising branched, septate, pseudoparaphyses, anastomosing between and above the asci, embedded in a gelatinous matrix. Asci 8-spored, bitunicate, cylindrical, with short, rounded pedicel, apex rounded with an ocular chamber. Ascospores overlapping, 1-3-seriate, ellipsoid to fusiform, uniseptate, constricted at the middle septum when immature, splitting at the middle of each cell at maturity, hyaline, smooth or slightly rough-walled. Asexual morph: Undetermined.

Type species - Semifissispora fusiformis H.J. Swart

Notes - Semifissispora was introduced in Pleosporales, with the type species S. fusiformis (Swart 1982) found on Eucalyptus leaf litter. Crous et al. (2015) established a new species $S$. natalis Crous et al. with sequence data. In their phylogenetic analysis, the placement of Semifissispora is shown in Massarinaceae (Pleosporales). However, a fresh collection with sequence data of the type species is needed to confirm the correct placement of Semifissispora.

Semifissispora fusiformis H.J. Swart, Trans. Br. mycol. Soc. 78(2): 259 (1982)

Index Fungorum number: IF111024; Facesoffungi number: FoF03680

Fig. 68

Parasitic on surface of dead leaves of Eucalyptus behriana F. Muell. Sexual morph: Ascomata 155-274 $\mu \mathrm{m}$ diameter $\times 248-288 \mu \mathrm{m}$ high, immersed and becoming erumpent at maturity, solitary or gregarious, globose to subglobose. Peridium comprising 2-layers of hyaline to dark brown cells of textura angularis, rounded ostiole at the center of mature ascomata. Hamathecium comprising 3-4 $\mu \mathrm{m}$ wide, branched, septate, pseudoparaphyses, anastomosing between and above the asci, embedded in a gelatinous matrix. Asci 70-94 $\times 15-20 \mu \mathrm{m}(\bar{x}=78 \times$ $18 \mu \mathrm{m}, \mathrm{n}=10), 8$-spored, bitunicate, cylindrical, with short, rounded pedicel, apex rounded, with an ocular chamber. Ascospores 30-34 $\times 7-8.5 \mu \mathrm{m}(\bar{x}=31 \times 8 \mu \mathrm{m}, \mathrm{n}=10)$, overlapping, 1-3seriate, ellipsoid to fusiform, uniseptate, constricted at the middle septum when immature, splitting at the middle of each cell at maturity, hyaline, wall smooth or slightly rough. Asexual morph: Undetermined.

Material examined - AUSTRALIA, Djerriwarrh Creek, near town, Melton Victoria R.D. 87, on dead fallen leaves of Eucalyptus behriana F. Muell. (Myrtaceae), DA 220, 22 September 1978, H.J. Swart 78.04 (DAR 37064, holotype).

\section{Mycosphaerellaceae Lindau}

The genus Episphaerella which was placed in Pseudoperisporiaceae (Barr 1997, Hyde et al. 2013) lacks pseudoparaphyses and, therefore, can be placed in Mycosphaerellaceae.

Episphaerella Petr., Annales Mycologici 22: 126 (1924)

Parasitic on living leaves, superficial, with large colonies, irregular, black and with numerous ascomata. Sexual morph: Ascomata 70-82.5 $\mu \mathrm{m}$ diameter, superficial, solitary to gregarious, globose to subglobose, dark brown, collapsed when dry, with apical ostiole, 7-11 $\mu \mathrm{m}$ diameter, lacking superficial mycelium. Peridium 7.5-10 $\mu \mathrm{m}$ wide, comprising 3-4 layers of brown cells of textura angularis, lacking hamathecial pseudoparaphyses. Asci $25-55 \times 12.5-17.5 \mu \mathrm{m}(\bar{x}=35 \times$ $15.5 \mu \mathrm{m}, \mathrm{n}=20$ ), 8-spored, bitunicate, oblong-ovoid, sub-cylindrical, sessile, with minute ocular chamber. Ascospores 12.5-15 $\times 5 \mu \mathrm{m}(\bar{x}=13 \times 5 \mu \mathrm{m}, \mathrm{n}=20), 2-3$-seriate, ellipsoidal oblongobovoid, ends rounded, 1-septate, hyaline. Asexual morph: Undetermined.

Type species - Episphaerella manihotis (Henn.) Petr.

Notes - Episphaerella was introduced by Petrak (1924) as a monotypic genus based on Dimerosporium manihotis and twelve species have since been added. Petrak (1924) provided a brief German diagnosis, while Müller \& von Arx (1962) revisited the genus with German descriptions of four species and provided a diagram of the infection process in E. manihotis, which 


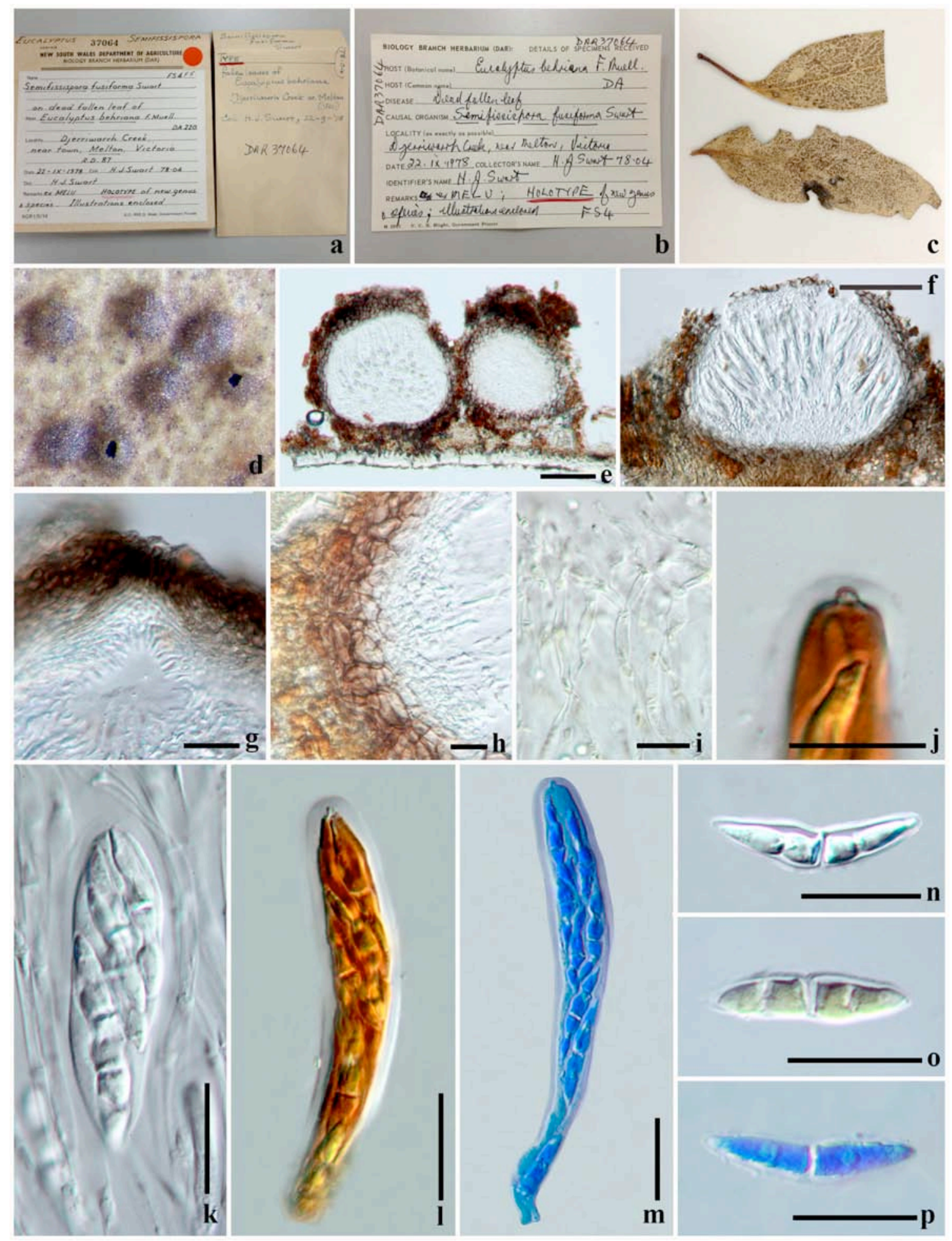

Figure 68 - Semifissispora fusiformis (DAR 37064, holotype). a-c Herbarium specimen, description and habit on leaves. $d$ Appearance of ascomata in leaf tissue. e, f Sections of ascomata. g Periphyses. h Peridium. i Hamathecium. j Ocular chamber. k Ascus. 1 Ascus in Melzer's reagent. $\mathrm{m}$ Ascus in cotton blue reagent. $\mathrm{n}$ Ascospore. o Ascospore in Melzer's reagent. $\mathrm{p}$ Ascospore when immature in cotton blue reagent. Scale bars: $\mathrm{e}, \mathrm{f}=100 \mu \mathrm{m}, \mathrm{g}, \mathrm{h}, \mathrm{j}-\mathrm{p}=20 \mu \mathrm{m}, \mathrm{i}=10 \mu \mathrm{m}$.

comprises internal mycelium with digitate processes within the leaf. Swart (1988) considered that the internal hyphae were important when transferring Parodiella banksiae to Episphaerella. Hansford (1946) questioned whether the character of internal mycelium was sufficient to separate this genus from Eudimeriolum. von Arx (1954) later combined Episphaerella with Eudimeriolum 
as E. manihotis (Henn.) Arx and included the genus in Dimeriaceae. Barr (1997) moved the genus to the family Pseudoperisporiaceae based on its biotrophic characteristic, small ascomata, superficial, numerous mycelium and internal mycelium intracellular within leaf tissues. In addition, Episphaerella shares similarities with some genera in Mycosphaerellaceae, such as ascoma feature, asci shape and ascospores. The genus Episphaerella is therefore placed in Mycosphaerellaceae, which is more appropriate than Pseudoperisporiaceae.

Episphaerella manihotis (Henn.) Petr., Annales Mycologici 22(1/2): 126 (1924)

三 Dimerosporium manihotis Henn., Hedwigia 43: 354 (1904)

= Eudimeriolum manihotis (Henn.) Arx, Acta Botanica Neerlandica 3: 88 (1954)

Index Fungorum number: IF270504; Facesoffungi number: FoF03681

Figs 69,70
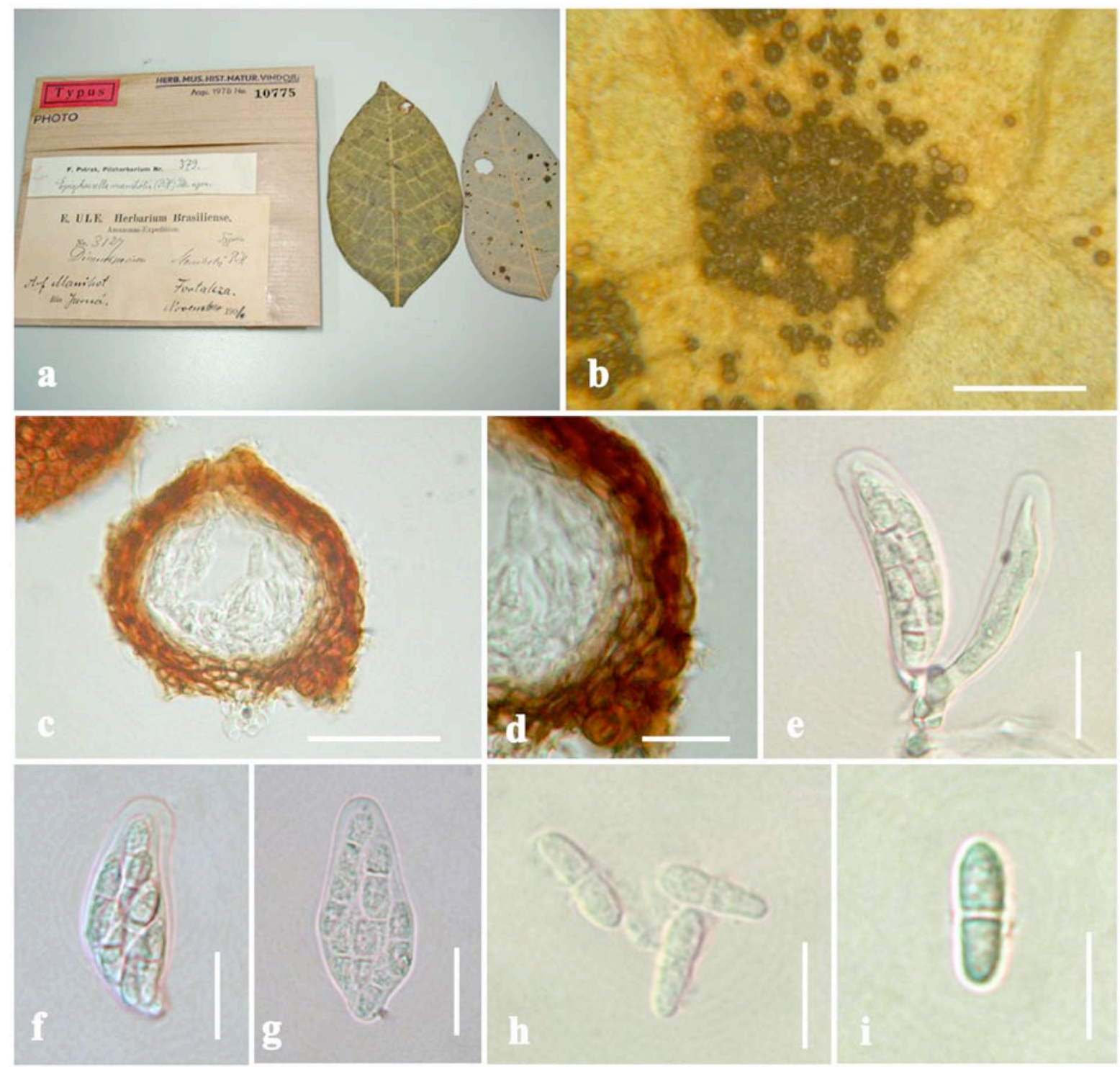

Figure 69 - Episphaerella manihotis (W Krypto 0010775, holotype). a Herbarium specimen and habit on leaves. b Appearance of ascomata on leaf surface. c Section of ascoma. d Peridium. e-g Asci. $\mathrm{h}, \mathrm{i}$ Ascospores. Scale bars: $\mathrm{a}, \mathrm{b}=500 \mu \mathrm{m}, \mathrm{c}=50 \mu \mathrm{m}, \mathrm{d}-\mathrm{g}=20 \mu \mathrm{m}, \mathrm{h}, \mathrm{i}=10 \mu \mathrm{m}$.

Parasitic on living leaves of Manihot sp., superficial, with large colonies, irregular, black and with numerous ascomata. Sexual morph: Ascomata 70-82.5 $\mu \mathrm{m}$ diameter, superficial, solitary to gregarious, globose to subglobose, dark brown, collapsed when dry, with apical ostiole, with 7-11 $\mu \mathrm{m}$ diameter, lacking superficial mycelium. Peridium $7.5-10 \mu \mathrm{m}$ wide, comprising 3-4 layers of 
brown cells of textura angularis, lacking hamathecial pseudoparaphyses. Asci $25-55 \times 12.5-17.5$ $\mu \mathrm{m}(\bar{x}=35 \times 15.5 \mu \mathrm{m}, \mathrm{n}=20), 8$-spored, bitunicate, oblong-ovoid, sub-cylindrical, sessile, with minute ocular chamber. Ascospores 12.5-15 $5 \mu \mathrm{m}(\bar{x}=13 \times 5 \mu \mathrm{m}, \mathrm{n}=20)$, 2-3-seriate, ellipsoidal oblong-obovoid, ends rounded, 1-septate, constricted at the septum, hyaline, smoothwalled. Asexual morph: Undetermined.

Material examined - BRAZIL, Rio Juruá, Fortaleza, on living leaves of Manihot sp. Mill. (Euphorbiaceae), November 1901, E.H.G Ule No. 3127 (W Krypto 0010775, holotype); BRAZIL, Amazonas, Jura, on living leaves of Manihot sp. (Euphorbiaceae), 1901, E.H.G. Ule (BPI 612199).

\section{Myrangiaceae Nyl.}

Currently, the family Myriangiaceae consists of ten genera parasitic or saprobic on leaves, bark or scale insects, with multi-loculate ascostromata, lacking hypostroma, with single ascus locule and muriform, light ascospores (Hyde et al. 2013, Dissanayake et al. 2014, Wijayawardene et al. 2014). Uleomyces shares several characters in common with the type species Myriangium duriaei, such as a stromatic ascomata, a single locule, subglobose asci and muriform, hyaline to pigmented ascospores. Uleomyces differs from the taxa in Cookellaceae by its ascostromata lacking hyphostroma and ascospore features. Therefore, the genus Uleomyces can be treated as a genus in the family Myriangiaceae.

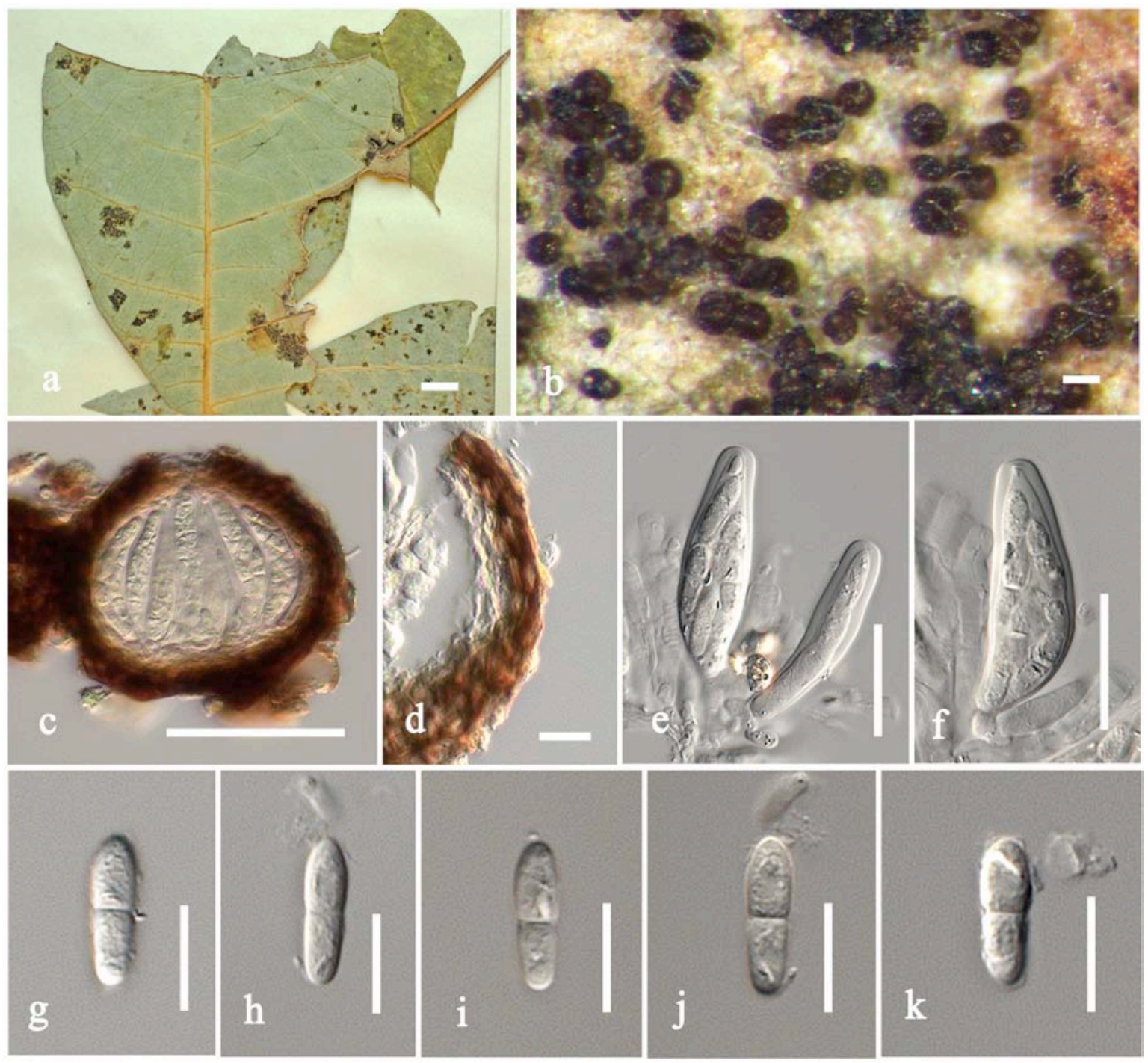

Figure 70 - Episphaerella manihotis (BPI 612199). a Herbarium specimen and habit on leaves. b Appearance of ascomata on leaf surface. c Section of ascoma. d Peridium. e-f Immature and mature asci. $\mathrm{g}-\mathrm{k}$ Ascospores. Scale bars: $\mathrm{a}=100 \mu \mathrm{m}, \mathrm{b}-\mathrm{c}=50 \mu \mathrm{m}, \mathrm{d}, \mathrm{g}-\mathrm{k}=10 \mu \mathrm{m}, \mathrm{e}, \mathrm{f}=20 \mu \mathrm{m}$. 
Uleomyces Henn., Hedwigia 34: 107 (1895)

Hyperparasites, fungicolous associated with Parmularia styracis on living leaves. Sexual morph: Ascostromata irregular effuse, in parasitic matrix, crustose, raised pulvinate, hump-shaped, tuberculate, lacking hypostroma, subglobose, semi-immersed, containing locules with individual asci, lacking pseudoparaphyses, stromata context dark red, rounded. Asci 8-spored, bitunicate, subellipsoid to broad clavate, sessile. Ascospores multi-seriate, conglobate, oblong-clavate to subperiform, muriform, multi-septate, sometimes constricted at the septa, brown to dark red. Asexual morph: Undetermined.

Type species - Uleomyces parasiticus Henn.

Notes - Uleomyces was introduced by Hennings (1895) to accommodate U. parasiticus and was placed in the family Hypocreaceae. Sydow \& Sydow (1917) combined five species (Ascomycetella sanguine Sacc, Cookella parasitica P. Henn., Myriangium sanguneum P. Henn., Phymatosphaeria sanguine Speg. and type species Uleomyces parasiticus P. Henn.), under $U$. sanguineus (Speg.) Syd. Index Fungorum (2017) lists the current name as Uleomyces parasiticus Henn. Moreau (1953) introduced a new family Uleomycetaceae (as Uléomycétacées) for the genus, but it was not validly published. von Arx \& Müller (1975) later included Uleomyces in Cookellaceae (under Dothideales) based on the features of ascostroma, asci and ascospores. Barr (1997) accepted Uleomyces in Cookellaceae under (Myriangiales). Lumbsch \& Huhndorf (2010) also listed the genus Uleomyces in Cookellaceae under Dothideomycetes order incertae sedis. The protologue of Arnaud (1925) showed that Uleomyces sanguineus (= Uleomyces parasiticus) was associated with a fungal species in Parmulariaceae as a large and black colony, while Uleomyces sanguineus was a small colony in Fig. 71 a. Uleomyces is characterised by being fungicolous, ascostromata that are irregular effuse, hump-shaped, tuberculate, lacking pseudoparaphyses, and muriform, multi-septate, brown to dark red ascospores. Twenty-three epithets of Uleomyces are listed in Index Fungorum (2017). In this study, we accept Uleomyces in Myriangiaceae, Myriangiales based on the characteristics of ascostromata and ascospores.

Uleomyces parasiticus Henn., Hedwigia 34: 107 (1895)

$\equiv$ Cookella parasitica (Henn.) Henn., Bot. Jb. 28(3): 275 (1900)

= Phymatosphaeria sanguinea Speg., Fungi Guarantici 2: 57 (1888)

= Ascomycetella sanguinea (Speg.) Sacc., Syll. fung. (Abellini) 8: 847 (1889)

= Uleomyces sanguineus (Speg.) Syd. \& P. Syd., Annls mycol. 15(3/4): 219 (1917)

Index Fungorum number: IF166125; Facesoffungi number: FoF03682

Fig. 71

Hyperparasites, fungicolous associated with Parmularia styracis on living leaves of Styrax sp. Sexual morph: Ascostromata irregular effuse, in parasitic matrix, crustose, raised pulvinate, hump-shaped, tuberculate, lacking hypostroma, subglobose, semi-immersed, containing locules with individual asci, lacking pseudoparaphyses, stromata context dark red, rounded. Asci 60-100 $\times$ 30-50 $\mu \mathrm{m}, 8$-spored, bitunicate, subellipsoid to broad clavate, sessile. Ascospores 22-32 × 11-15 $\mu \mathrm{m}$, multi-seriate, conglobate, oblong-clavate to subperiform, muriform, multi-septate, sometime constricted at the septa, brown to dark red (from Hennings 1895). Asexual morph: Undetermined.

Nematotheciaceae Boonmee \& K.D. Hyde, fam. nov.

Index Fungorum number: IF553836; Facesoffungi number: FoF03700

Parasitic on lower surface of living leaves. Sexual morph Ascomata superficial, gregarious, some solitary, with a subiculum, globose to subglobose, dark brown, with apical ostiole, covered by dark brown mycelium, with or without hyphopodia-like structures. Peridium comprising multilayers of dark brown cells of textura angularis. Hamathecium comprising numerous, cylindrical, filiform, branched, septate, pseudoparaphyses. Asci 8-spored, bitunicate, cylindrical-subclavate, sessile. Ascospores fasciculate, multi-seriate, elongate fusiform, curved or flexuous, tapering towards the acute ends, multi-septate, brown. Asexual morph: Undetermined.

Family type - Nematothecium Syd. \& P. Syd. 
Notes - The new family Nematotheciaceae is introduced to accommodate three parasitic genera growing on living leaves, characterized by superficial, dark pigmented ascomata, with superficial mycelia, cylindrical to subclavate, broadly ellipsoid, bitunicate asci and cylindrical to elongate fusiform, multi-septate, hyaline to light pigmented ascospores. Nematotheciaceae shares common characters with taxa in Tubeufiaceae in the features of ascomata, asci and ascospores. However, Nematotheciaceae differs from Tubeufiaceae by being parasitic and occurring on living leaves. Nematothecium is assigned as the type genus of the family and two genera Nematostigma and Ophioparodia are included in this family.
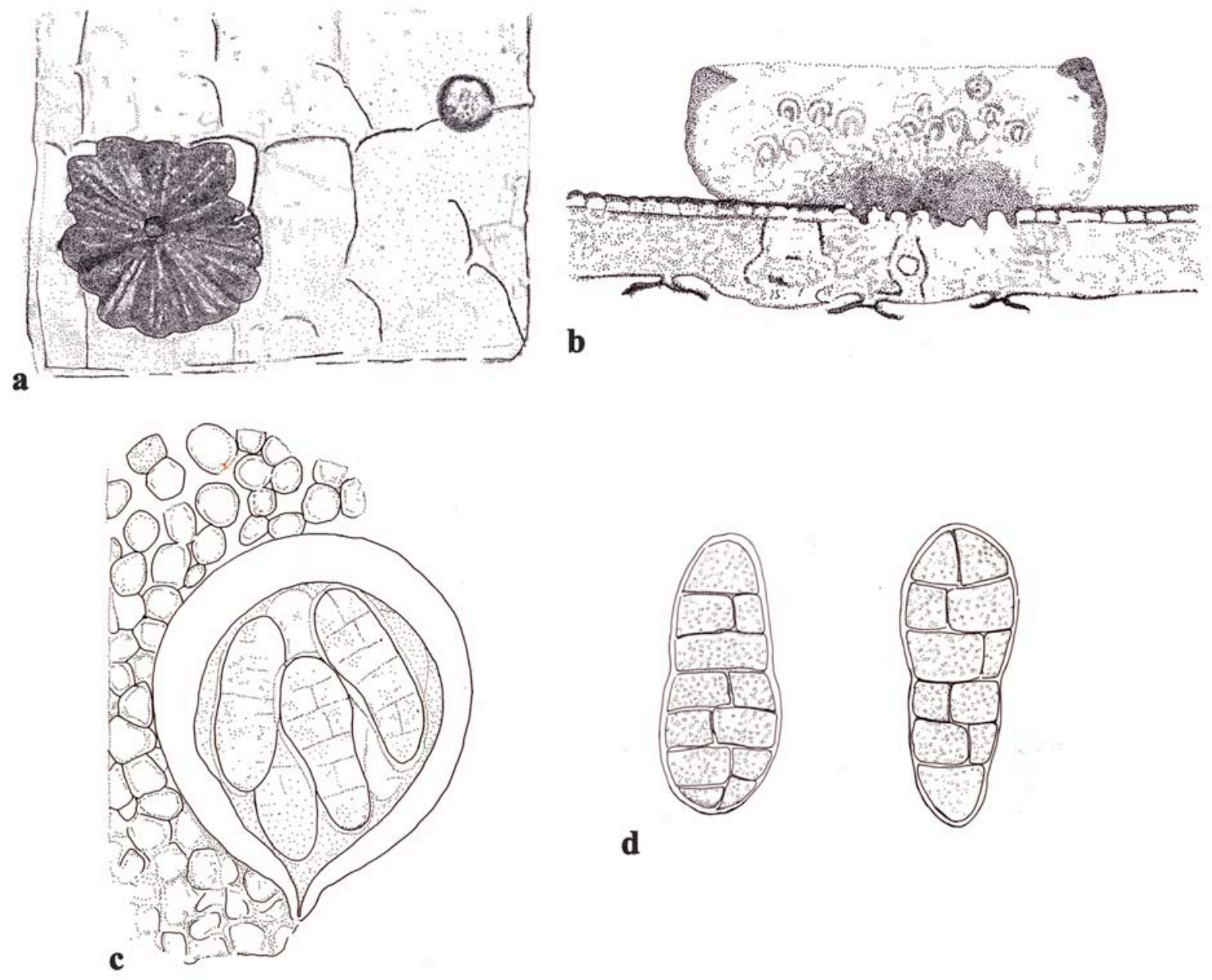

d
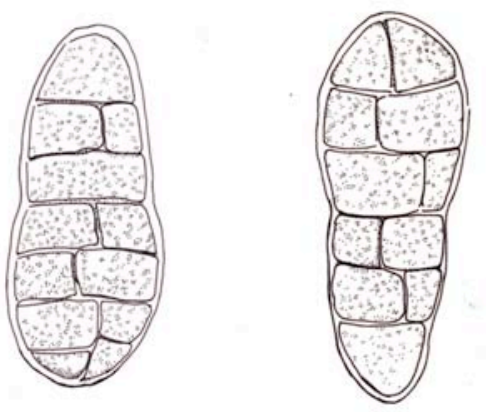

Figure 71 - Uleomyces parasiticus (redrawing from Plate 1 under the name Uleomyces sanguineus, in Arnaud 1925). a Appearance of a small ascostroma of Uleomyces sanguineus on leaf surface in the upper right corner and associated with a species of Parmulariaceae as a large and black shield-like colony in the bottom left corner. b Section of ascoma and asci. c Ascus and subglobose cells. d Ascospores.

Nematothecium Syd. \& P. Syd., Leafl. of Philipp. Bot. 5: 1534 (1912)

Parasitic on lower surface of living leaves. Sexual morph Ascomata superficial, gregarious, some solitary, with a subiculum, globose-subglobose, dark brown, with apical ostiole, covered by dark brown mycelium. Peridium comprising multi-layers of dark brown cells of textura angularis. Hamathecium comprising numerous, cylindrical, filiform, branched, septate, hyaline and partly pigment pseudoparaphyses. Asci 8-spored, bitunicate, cylindrical to subclavate, sessile, slightly curved. Ascospores fasciculate, elongate fusiform, curved or flexuous, tapering towards the acute ends, multi-septate (indistinct), hyaline when immature, brown at maturity, becoming pinkish in 5\% KOH, smooth-walled. Asexual morph: Undetermined. 
Type species - Nematothecium vinosum Syd. \& P. Syd.

Notes - Sydow \& Sydow (1912) described and introduced Nematothecium to accommodate $N$. vinosum from the Island of Palawan in the Philippines. The genus is characterized by large mycelium colonies, irregular, superficial ascomata with dark red ascomata, bitunicate asci and elongate fusiform, curved or flexuous, multi-septate, hyaline to red brown ascospores. Nematothecium comprises six species and has been placed in various families based on some characters (Clements \& Shear 1931, Hansford 1946, von Arx and Müller 1975, Pirozynski 1977, Rossman 1987, Hawksworth et al. 1995, Barr 1997). Presently, Nematothecium is included in Pseudoperisporiaceae based on its hyperparasitic habit and bitunicate asci (Kirk et al. 2008, Lumbsch \& Huhndorf 2010, Hyde et al. 2013). However, the elongate fusiform and multi-septate ascospores are typical of genera in Tubeufiaceae. Nematothecium is therefore placed in the new family Nematotheciaceae.

Nematothecium vinosum Syd. \& P. Syd., Leafl. Philipp. Bot. 5(76): 1534 (1912)

Index Fungorum number: IF249022; Facesoffungi number: FoF03243

Figs 72,73

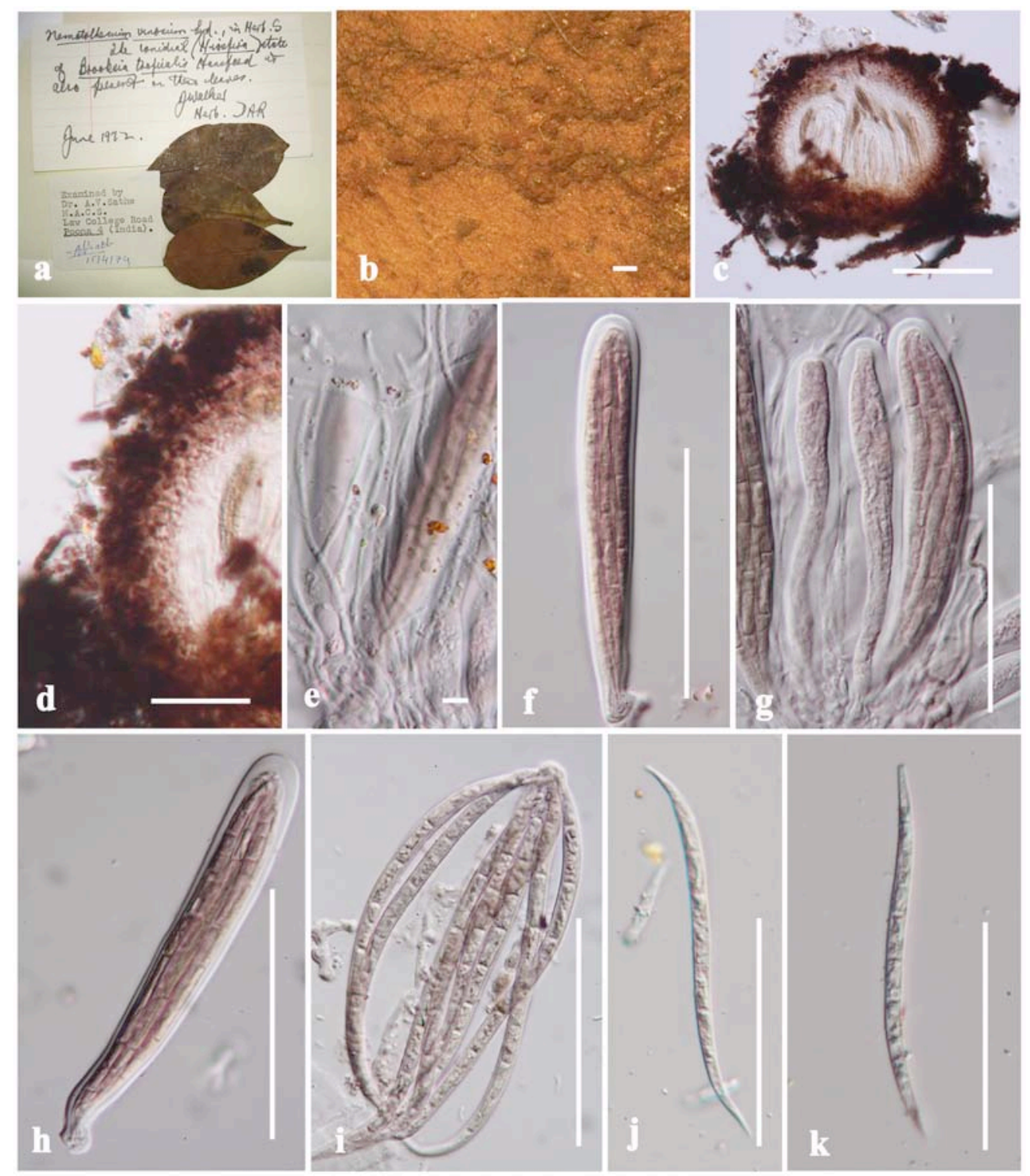

Figure 72 - Nematothecium vinosum (S-F10269, holotype). a Herbarium specimen and habit on leaves. b Appearance of ascomata on leaf surface. c Section of ascoma. d Peridium. e Pseudoparaphyses. g-h Asci. i-k Ascospores. Scale bars: $\mathrm{b}=500 \mu \mathrm{m}, \mathrm{c}, \mathrm{f}-\mathrm{k}=50 \mu \mathrm{m}, \mathrm{d}=40 \mu \mathrm{m}$ e $=5 \mu \mathrm{m}$. 
Parasitic on lower surface of living leaves of Eugenia incarnata Elmer. Sexual morph Ascomata 152-171(-206) $\mu \mathrm{m}$ diameter $\times 165-195 \mu \mathrm{m}$ high, superficial, gregarious, clustered, some solitary, with a subiculum, globose-subglobose, dark brown, with apical ostiole, covered by dark brown mycelium. Peridium 46.5-54 $\mu \mathrm{m}$ wide, comprising multi-layers of dark brown cells of textura angularis. Hamathecium 1-2 $\mu \mathrm{m}$ wide, comprising numerous, cylindrical, filiform, branched, septate, hyaline and partly pigmented pseudoparaphyses. Asci $81.5-94.5 \times 13-16 \mu \mathrm{m}(\bar{x}$ $=87.5 \times 14 \mu \mathrm{m}, \mathrm{n}=10), 8$-spored, bitunicate, cylindrical-subclavate, sessile, slightly curved. Ascospores 74-84 $\times 3-4 \mu \mathrm{m}(\bar{x}=79 \times 3 \mu \mathrm{m}, \mathrm{n}=10)$, fasciculate, elongate fusiform, curved or

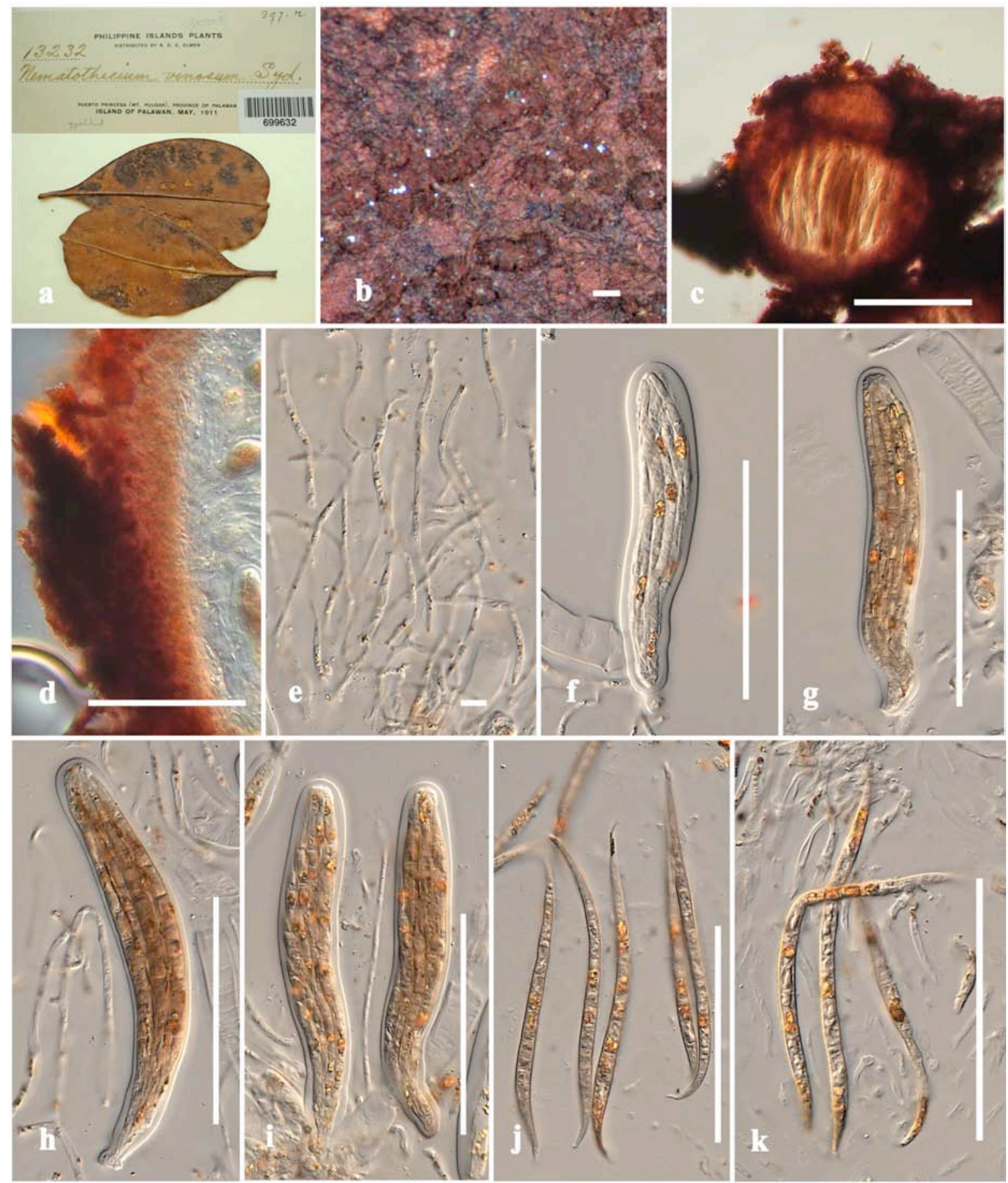

Figure 73 - Nematothecium vinosum (BPI 699632, lectotype). a Herbarium specimen and habit on leaves. b Appearance of ascomata on leaf surface. c Section of ascoma. d Peridium. e Pseudoparaphyses. $\mathrm{f}-\mathrm{i}$ Immature and mature asci. j, k Ascospores. Scale bars: $\mathrm{b}=200 \mu \mathrm{m}, \mathrm{c}=100$ $\mu \mathrm{m}, \mathrm{d}, \mathrm{f}-\mathrm{k}=50 \mu \mathrm{m}, \mathrm{e}=5 \mu \mathrm{m}$. 
flexuous, tapering towards the acute ends, indistinctly multi-septate, not constricted at the septa, hyaline when immature, brown at maturity, becoming pinkish in $5 \% \mathrm{KOH}$, smooth-walled. Asexual morph: Undetermined.

Material examined - PHILIPPINES, Palawan, Island of Palawan: Puerto Princesa, Mt Pulgar, on living leaves of Eugenia incarnata Elmer. (Myrtaceae), May 1911, A.D.E. Elmer (no. 13232), (S-F10269, holotype, BPI 699632, lectotype).

Nematostigma Syd. \& P. Syd., Annls mycol. 11(3): 262 (1913)

Parasitic on living leaves, with superficial, large colonies, irregular, mycelium appressed to cuticle of host, with outwardly radiating hyphae, 6-8 $\mu \mathrm{m}$ wide, flexuous, branched, septate, dark brown, hyphopodia-like structures present, ostiole obscure. Sexual morph: Ascomata superficial, globose to subglobose, grouped, unilocular, with appendage hyphae or setae, septate, dark brown, surrounded by dark brown hyphae, seated on a subiculum or hyphal pack. Peridium comprising dark brown cells of textura angularis. Hamathecium comprising cylindrical, branched, septate, hyaline, pseudoparaphyses. Asci 8-spored, bitunicate, broadly ellipsoid, oval to clavate, sessile or with short pedicel. Ascospores 2-3-seriate, elongate, broadly cylindric-fusiform, slightly curved, tapering towards sub-rounded and asymmetrical ends, multi-septate, hyaline, pinkish when stained in $5 \% \mathrm{KOH}$, with thin gelatinous sheath, smooth to rough-walled with minute guttules. Asexual morph: Undetermined.

Type species - Nematostigma obducens Syd. \& P. Syd.

Notes - Sydow \& Sydow (1913) introduced Nematostigma in Sphaeriaceae characterized by dark brown, sparse setae, sphaerical ascomata, and hyaline, multi-septate ascospores, typified by $N$. obducens. Hansford (1946) re-examined the type specimen and illustrated the mycelium penetrating into the leaf tissues without haustoria and placed N. obducens in Parodiopsidaceae (= Parodiellinaceae). Based on it being parasitic on living leaves, superficial mycelial colonies, hyphae penetrating host tissues, solitary ascomata, with a subiculum, bitunicate asci and colourless to pigmented, septate ascospores, von Arx \& Müller (1975) moved Nematostigma to Dimeriaceae. Eriksson \& Hawksworth (1993) agreed with von Arx \& Müller (1975). Hawksworth et al. (1995) included Nematostigma in Pseudoperisporiaceae and this was followed by Barr (1997), Kirk et al. (2008), Lumbsch \& Huhndorf (2010) and Hyde et al. (2013). Based on its morphological characters, Nematostigma is included in the new family Nematotheciaceae.

Nematostigma obducens Syd. \& P. Syd., Annls mycol. 11(3): 262 (1913)

Index Fungorum number: IF249044; Facesoffungi number: FoF03701

Fig. 74

Parasitic on living leaves of Scutia indica Brongn., with superficial, large colonies, irregular, mycelium appressed to cuticle of host, with outwardly radiating hyphae, $6-8 \mu \mathrm{m}$ wide, flexuous, branched, septate, dark brown, 10-11 $\mu \mathrm{m}$ diameter, dark brown, hyphopodia-like structures present, ostiole obscure. Sexual morph: Ascomata 95-115(-179.5) $\mu \mathrm{m}$ diameter $\times 114-155.5(-170)$ $\mu \mathrm{m}$ high, superficial, globose to subglobose, grouped, unilocular, with appendage hyphae or setae, septate, dark brown, surrounded by dark brown hyphae, seated on subiculum or hyphal pack. Peridium 23-31 $\mu \mathrm{m}$ wide, comprising 3-4 layers of dark brown cells of textura angularis. Hamathecium 2-2.5 $\mu \mathrm{m}$ wide, comprising cylindrical, branched, septate, hyaline, pseudoparaphyses. Asci 83-118 $\times 27-45 \mu \mathrm{m}(\bar{x}=99 \times 34.5 \mu \mathrm{m}, \mathrm{n}=20), 8$-spored, bitunicate, broadly ellipsoid, oval to clavate, sessile or with short pedicel. Ascospores $50-62 \times 7-9.5 \mu \mathrm{m}(\bar{x}=$ $56 \times 8 \mu \mathrm{m}, \mathrm{n}=20), 2-3$-seriate, elongate, broadly cylindric-fusiform, slightly curved, tapering towards sub-rounded and asymmetrical ends, 6-7-septate, hyaline, pinkish when stained in 5\% $\mathrm{KOH}$, with thin gelatinous sheath, smooth to rough-walled with minute guttules. Asexual morph: Undetermined.

Material examined - SOUTH AFRICA, Cape Province, Port Elizabeth, on living leaves of Scutia indica Brongn. (Rhamnaceae), 23 March 1911, E.M. Doidge (Pole Evans J.B. No. 1242), (S-F10256, holotype). 
Ophioparodia Petr. \& Cif., Annls mycol. 30(3/4): 223 (1932)

Parasitic on the lower surface of living leaves. Sexual morph: Ascomata superficial, seated on a subiculum, solitary to gregarious, globose to subglobose, with apical pore, surrounded by brown mycelium. Peridium comprising multi-layers of brown to dark brown cells of textura angularis, inner layers compressed, lacking pseudoparaphyses. Asci 8-spored, bitunicate, cylindrical to subclavate, sessile, slightly curved, apex rounded. Ascospores fasciculate, cylindrical fusiform, straight to slightly curved, multi-septate, not constricted at the septa, hyaline to pale brown, smooth-walled. Asexual morph: Undetermined.

Type species - Ophioparodia pulchra Petr. \& Cif.

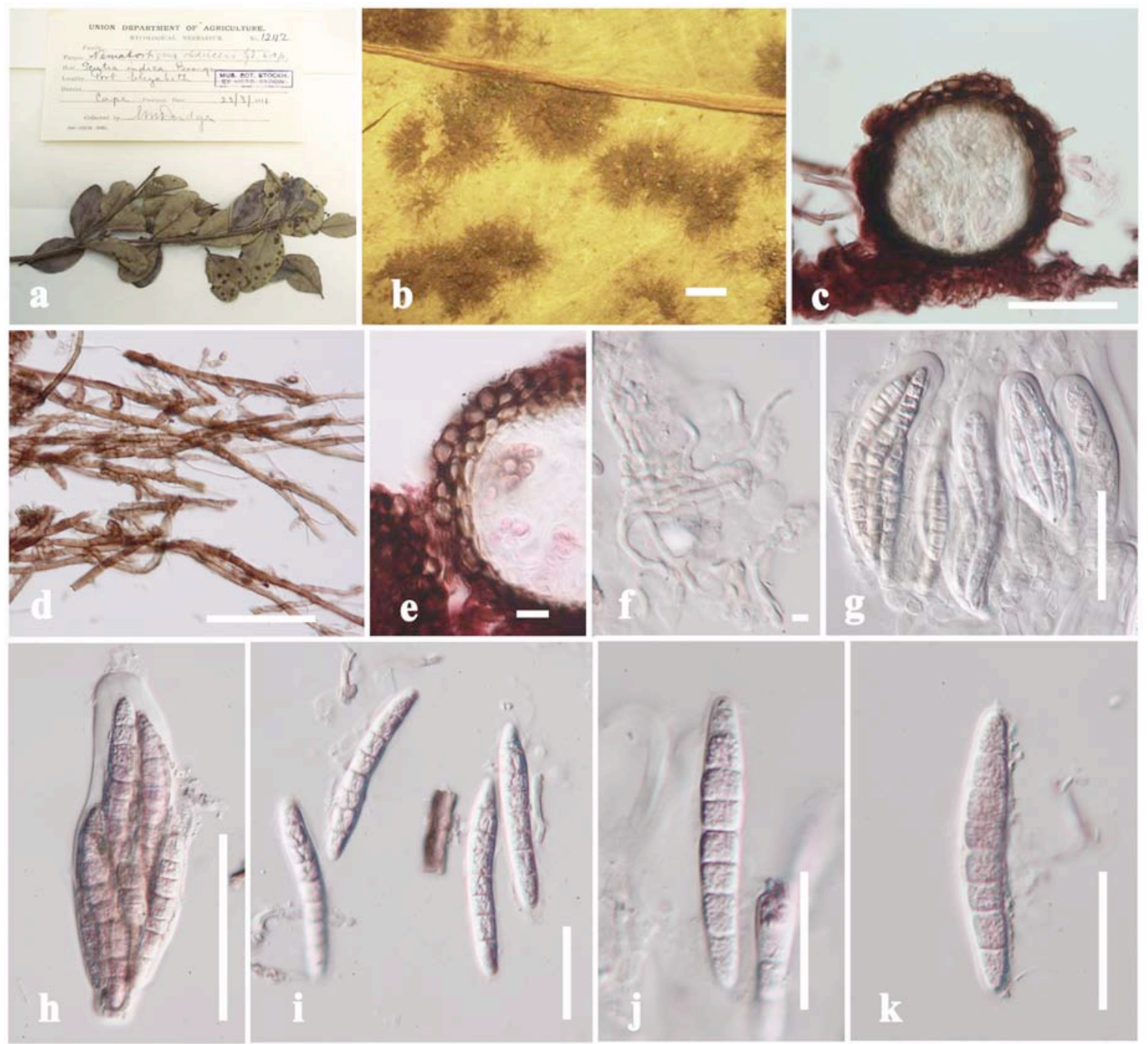

Figure 74 - Nematostigma obducens (S-F10256, holotype). a Herbarium specimen and habit on leaves. b Appearance of fungal colonies and ascomata on leaf surface. c Section of ascoma. d Squash mount of mycelia with hyphopodia-like structures. e Peridium. f Pseudoparaphyses. g, $h$ Asci. i-k Ascospores. Scale bars: $\mathrm{b}=500 \mu \mathrm{m}, \mathrm{c}, \mathrm{d}, \mathrm{g}, \mathrm{h}=50 \mu \mathrm{m}, \mathrm{e}, \mathrm{i}-\mathrm{k}=20 \mu \mathrm{m}, \mathrm{f}=5 \mu \mathrm{m}$.

Notes - Ophioparodia was introduced by Petrak \& Ciferri (1932) as a monotypic genus typified by $O$. pulchra and the asexual morph was mentioned as septoidium. Hansford (1946) revisited the genus and placed it in Parodiellinaceae based on the mycelium penetrating the stomata into the plant tissues. Sivanesan (1984) re-examined the type specimen of O. pulchra and included the genus in the family Parodiopsidaceae based on its Septoidium-like conidia. We could not find the pseudoparaphyses in Ophioparodia or the asexual morph (Fig. 75). Ophioparodia can be distinguished from all genera in Parodiopsidaceae by having elongate, cylindrical, fusiform and 
multi-septate ascospores. Ophioparodia shares common features with Nematothecium such as superficial, globose to subglobose, uniloculate ascomata, cylindrical asci and long, multi-septate ascospores and a hyphomycetous asexual morph. Ophioparodia is therefore included in Nematotheciaceae.

Ophioparodia pulchra Petr. \& Cif. Annls mycol. 30(3/4): 223 (1932)

Index Fungorum number: IF275642; Facesoffungi number: FoF03702

Parasitic on the lower surface of living leaves of Tetragastris balsamifera (Sw.) Oken. Sexual morph: Ascomata 187.5-235 $\mu \mathrm{m}$ diameter, superficial, seated on a subiculum, solitary to gregarious, globose to subglobose, with apical pore, surrounded by brown mycelium. Peridium 40$50 \mu \mathrm{m}$ wide, comprising multi-layers of brown to dark brown cells of textura angularis, inner layers compressed, lacking pseudoparaphyses. Asci 117.5-147.5 × 15-22.5 $\mu \mathrm{m}(\bar{x}=131 \times 19 \mu \mathrm{m}$, $\mathrm{n}=20$ ), 8-spored, bitunicate, cylindrical to subclavate, sessile, slightly curved, apex rounded. Ascospores 95-145 $\times 5-7.5 \mu \mathrm{m}(\bar{x}=118.5 \times 6 \mu \mathrm{m}, \mathrm{n}=20)$, fasciculate, cylindrical fusiform, straight to slightly curved, 7-septate, not constricted at the septa, hyaline to pale brown, smoothwalled. Asexual morph: Undetermined.

Material examined - DOMINICAN REPUBLIC, Santo Domingo, Villa Altagracia, Cordillera Central, on living leaves of Tetragastris balsamifera (Sw.) Oken (Burseraceae), $18.75^{\circ}$ - 70.5 7 January 1930, E.L. Ekman No. 2866 (W Krypto 1978-0005503, holotype).

Neoparodiaceae Boonmee \& K.D. Hyde, fam. nov.

Index Fungorum number: IF553832; Facesoffungi number: FoF03683

Epiphytic or parasitic on living leaves. Sexual morph: Colonies up to $2 \mathrm{~mm}$ diameter, superficial, subcircular, outwardly radiating, dense, branched, septate, solitary as black spots, with dark brown mycelia. Ascostromata epiphyllous or hypophyllous, superficial, crustose, on a subiculum, solitary, scattered, dark brown, multi-loculate, comprising subglobose locules, thickened at the base, lacking pseudoparaphyses. Peridium comprising hyaline to brown cells of textura angularis. Asci 8-spored, bitunicate, broadly clavate, oblong to obovoid, sessile or with short pedicel, apically thickened, with an acute to subacute ocular chamber. Ascospores overlapping 2-seriate, conglobate, broadly ellipsoid, ends rounded, each cell subglobose, 1-septate, reddish-brown to dark brown, separated by light brown regions. Asexual morph: Undetermined.

Family type - Neoparodia Petr. \& Cif.

Notes - A new family Neoparodiaceae is introduced to accommodate the genus Neoparodia based on its morphology. The dark brown superficial, crustose and multi-loculate ascostromata of Neoparodia ekmanii are similar to characteristics of the genera of Cookellaceae and Myriangiaceae (Hyde et al. 2013, Dissanayake et al. 2014). Neoparodiaceae can be distinguished from these two families by its colonies, ascostromata, broadly clavate asci and broadly ellipsoid, 1-septate, dark brown ascospores.

Neoparodia Petr. \& Cif. Annls mycol. 30(3/4): 219 (1932)

Epiphytic or parasitic on living leaves. Sexual morph: Colonies large up to $2 \mathrm{~mm}$ diameter, superficial, subcircular, with outwardly radiating, dense, branched, septate, dark brown mycelia, solitary as black spots. Ascostromata epiphyllous or hypophyllous, superficial, crustose, with a subiculum, solitary, scattered, dark brown, multi-loculate, comprising subglobose locules, thickened at the base, lacking pseudoparaphyses. Peridium comprising 2 layers of hyaline to brown cells of textura angularis. Asci 8-spored, bitunicate, broadly clavate, oblong to obovoid, sessile or with short pedicel, apically thickened, with an acute to subacute ocular chamber. Ascospores overlapping 2-seriate, conglobate, broadly ellipsoid, ends rounded, each cell subglobose, 1-septate, reddish-brown to dark brown, separated by light brown regions, smooth-walled. Asexual morph: Undetermined.

Type species - Neoparodia ekmanii Petr. \& Cif. 

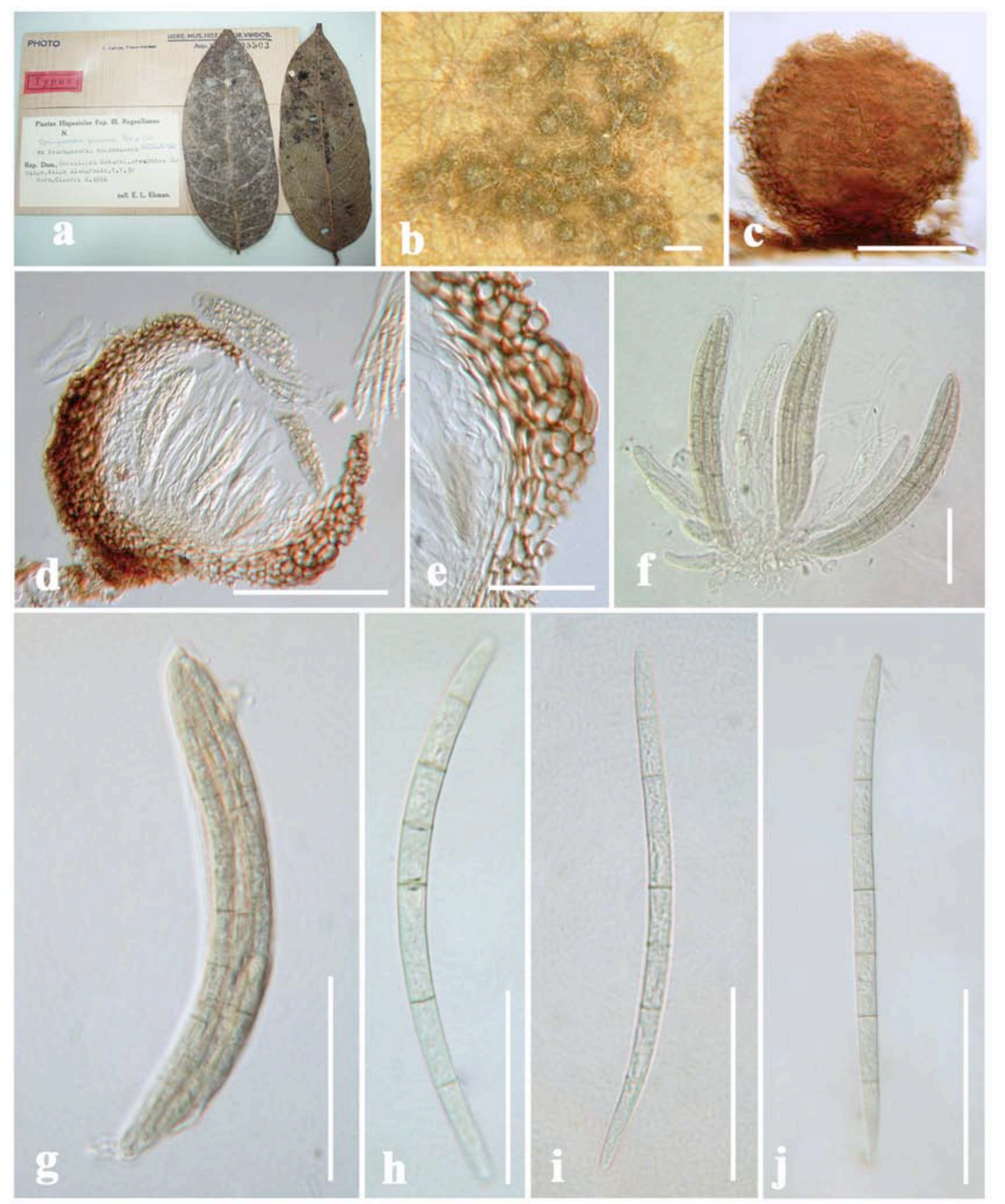

Figure 75 - Ophioparodia pulchra (W Krypto 1978-0005503, holotype). a Herbarium specimen and habit on leaves. b Appearance of ascomata on leaf surface. c, d Squash mount and section of ascomata. e Close up of peridium cells. f, g Asci. $h-j$ Ascospores. Scale bars: $b=200 \mu \mathrm{m}, \mathrm{c}, \mathrm{d}=$ $100 \mu \mathrm{m}, \mathrm{e}-\mathrm{j}=50 \mu \mathrm{m}$.

Notes - Neoparodia was introduced by Petrak \& Ciferri (1932) for a monotypic genus based on the type species $N$. ekmanii. The genus is characterized by crustose, multi-loculate ascostromata, seated on a thickened subiculum, with radial mycelia, broadly clavate asci and having conglobate, 1-septate, dark pigmented ascospores, each cell subglobose with a light brown equatorial band. Müller \& von Arx (1962) placed this genus in Perisporiopsidaceae based on superficial structures on living leaves. Kirk et al. (2008), Lumbsch \& Huhndorf (2010), Hyde et al. (2013) and Wijayawardene et al. (2014) included Neoparodia in Parodiopsidaceae. The asexual morph has been mentioned as hyphomycetous chuppia-like and sarcinella-like (Kendrick 1979, Kirk et al. 2008, Seifert et al. 2011). We observed Neoparodia ekmanii and its asexual morph (see Fig. 76, in 
$\mathrm{h}$ and i). We introduce the new family Neoparodiaceae, because it has a suite of characters that differ from other families of Dothideomycetes.

Neoparodia ekmanii Petr. \& Cif. Annls mycol. 30(3/4): 219 (1932)

Index Fungorum number: IF263814; Facesoffungi number: FoF03684

Fig. 76

Epiphytic or parasitic on living leaves of Trema micrantha (L.) Blume. Sexual morph: Colonies 1-1.5(-2) mm diameter, superficial, subcircular, with outwardly radiating, dense, branched, septate, dark brown mycelia, solitary as black spots. Ascostromata 45-187.5 $\mu \mathrm{m}$ diameter $\times 75-100 \mu \mathrm{m}$ high, epiphyllous or hypophyllous, superficial, crustose, on a subiculum, solitary, scattered, dark brown, multi-loculate, comprising subglobose locules, 50-125(-140) $\mu \mathrm{m}$ diameter, each locule, thickened at the base, lacking pseudoparaphyses. Peridium $12.5-\mu \mathrm{m}$ wide, comprising 2 layers of hyaline to brown cells of textura angularis. Asci $85-112.5 \times 27.5-37.5 \mu \mathrm{m}$ $(\bar{x}=99 \times 32 \mu \mathrm{m}, \mathrm{n}=10), 8$-spored, bitunicate, broadly clavate, oblong to obovoid, sessile or with short pedicel, apically thickened, with acute to subacute ocular chamber. Ascospores 22.5-27.5 $\times$ 12.5-15 $\mu \mathrm{m}(\bar{x}=26 \times 13 \mu \mathrm{m}, \mathrm{n}=10)$, overlapping 2-seriate, conglobate, broadly ellipsoid, ends rounded, constricted at the septum, each cell subglobose, reddish brown to dark brown, each cell subglobose with a light brown equatorial band, smooth-walled. Asexual morph: Undetermined.

Material examined - DOMINICAN REPUBLIC, Santiago, El Cerrazo, on living leaves of Trema micrantha (L.) Blume (Ulmaceae), $19.53^{\circ} \mathrm{N}, 70.62^{\circ} \mathrm{W}$ elev. $800 \mathrm{msl}, 20$ February 1930, P.L. Clemen No. 3518 (W Krypto 1977-0019515, holotype).

Opegraphaceae Körb. ex Stizenb. [as 'Opegrapheae'], Ber. Tät. St Gall. naturw. Ges.: 153 (1862) [1861-62]

Notes - The family Opegraphaceae was introduced by Stizenberger (1862) as 'Opegrapheae' and is typified by Opegrapha Ach. The family has been accepted by many mycologists, although Hawksworth et al. (1995) included the family in Roccellaceae. However, the family was reinstated by Ertz \& Tehler (2011). The taxonomic classification of Opegraphaceae within Arthoniales has been discussed and considerably changed by various authors (Luttrell 1973, Henssen \& Jahns 1974, von Arx \& Müller 1975, Hawksworth \& Eriksson 1986, Hawksworth et al. 1995, Ertz et al. 2009, Ertz \& Tehler 2011, Frisch et al. 2014, Lücking et al. 2017). Luttrell (1973) classified Opegraphaceae together with Arthoniaceae and Lecanactidaceae in the order Hysteriales based on their ascomata having boat-shaped to linear, carbonaceous pseudothecia, opening by a longitudinal slit, somewhat similar to Hysteriaceae (Ertz et al. 2009). Barr (1979) agreed with Luttrell (1973) to treat Opegraphaceae and Roccellaceae in Hysteriales, however, she assigned Arthoniaceae to Myriangiales. von Arx \& Müller (1975) accommodated Arthoniaceae in the order Dothideales but omitted the classification of Lecanactidaceae, Opegraphaceae, and Roccellaceae. Furthermore, Hawksworth \& Eriksson (1986) introduced the new order Opegraphales to accommodate Opegraphaceae and Roccellaceae and accepted the species with a crustose, ecorticate thallus and lecideine ascomata in Opegraphaceae. However, Ertz \& Tehler (2011) confirmed the taxonomic placement of Opegraphaceae in Arthoniales based on the phylogenetic analysis of a combined LSU and RPB2 sequence data. Based on phylogenetic analyses of a combined LSU, mtSSU and RPB2 dataset, Ertz et al. (2009) accepted the genera Chiodecton, Enterographa, Erythrodecton, Lecanactis, Opegrapha, and Schismatomma in Opegraphaceae. Subsequently, Ertz \& Tehler (2011) resurrected the genera Combea, Dictyographa, Dolichocarpus, Ingaderia, Llimonaea flexuosa, Paralecanographa, Paraingaderia, Paraschismatomma, Pentagenella, Schizopelte and Sparria in Opegraphaceae. Lücking et al. (2017) accepted 15 genera in Opegraphaceae viz. Combea, Cresponea, Dictyographa, Dolichocarpus, Fouragea, Ingaderia, Llimonaea, Nyungwea, Opegrapha, Paraingaderia, Paraschismatomma, Pentagenella, Schizopelte, Sclerophyton and Sparria.

Opegrapha Ach., K. Vetensk-Acad. Nya Handl. 30: 97 (1809)

= Kalaallia Alstrup \& D. Hawksw., Meddr Grønland, Biosc. 31: 38 (1990) 

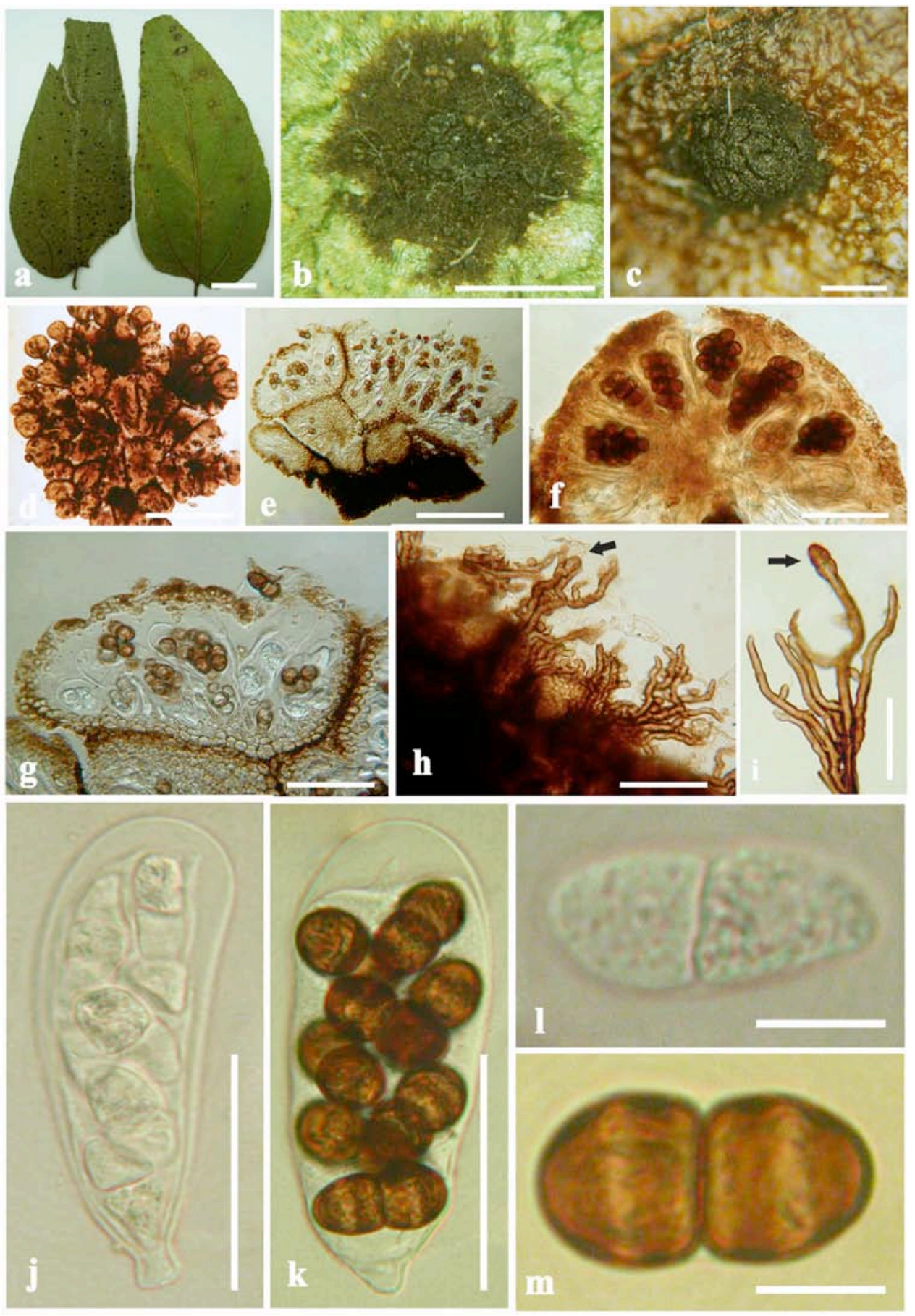

Figure 76 - Neoparodia ekmanii (W Krypto 1977-0019515, holotype). a Herbarium specimen and habit on leaves. b Appearance of colony and ascostromata seated on mycelium. c Close up of ascostroma. d Squash mount of ascostroma. e Section of ascomal locules. $f$, g Close up of ascomal locules. h Mycelium radiating outwardly and apical conidia-like structures (arrow). i Anastomosing and branched mycelium and apical conidium-like spores. $\mathrm{j}, \mathrm{k}$ Immature and mature asci. $1, \mathrm{~m}$ Immature and mature ascospores. Scale bars: $\mathrm{a}=5 \mathrm{~mm}, \mathrm{~b}=1 \mathrm{~mm}, \mathrm{c}-\mathrm{g}=100 \mu \mathrm{m}, \mathrm{h}-\mathrm{k}=50 \mu \mathrm{m}, 1$, $\mathrm{m}=10 \mu \mathrm{m}$.

Lichenicolous on Hymenelia lacustris. Sexual morph: Ascomata perithecial, arising in loose groups, forming patches up $0.2 \mathrm{~mm}$ diameter, black, immersed to erumpent on the host thallus, globose to subglobose, clustered, gregarious, ostiole discrete to gaping, with apical pore. Peridium unequally thick, comprising apically thickened, loose hyphae of brown to dark brown pseudoparenchymatous cells, somewhat olivaceous in $5 \% \mathrm{KOH}$, arranged in a textura porrecta. 
Hamathecium comprising dense, branched, distinctly septate, anastomosed, cellular pseudoparaphyses, with $\mathrm{I}^{+}$, pale blue centrum. Asci 8-spored, bitunicate, clavate to cylindricclavate, with short pedicel, apex rounded, with a well-develop ocular chamber, apically thickened. Ascospores overlapping 2-3-seriate, hyaline or yellowish when stained by Lugol's iodine, ellipsoidal to fusiform, with round to acute ends, 1-3-septate, sometimes constricted at the septa, smooth-walled. Asexual morph: Undetermined.

Type species - Opegrapha vulgata (Ach.) Ach.

Notes - Opegrapha was introduced by Acharius (1809) to accommodate taxa forming, oblong-elongate, membranaceous apothecia, which are black at the apex, and pseudoparenchymatous cells, making up a crustaceous thallus. Opegrapha is a large and cosmopolitan genus comprising more than 1600 epithets and with over 361 species of lichenized and lichenicolous species (Kirk et al. 2008, Joseph \& Sinha 2012, Index Fungorum 2017). The genus is polyphyletic with several species nested in all the major clades identified within Arthoniales (Ertz et al. 2009, Ertz \& Tehler 2011). The polyphyletic status of Opegrapha can only be partly explained by morphological characters and this led to the problem for choosing the morphological character reflecting monophyletic groups (Ertz et al. 2009). However, Opegrapha sensu stricto based on the type species, O. vulgata formed a well-resolved lineage with other related genera within Opegraphaceae (Ertz \& Tehler 2011). To resolve the polyphyly of Opegrapha, new genera need to be designated for Opegrapha species sensu lato (Ertz et al. 2009, Ertz \& Tehler 2011).

Kalaallia was introduced by Alstrup \& Hawksworth (1990) as a monotypic genus to accommodate the lichenicolous species $K$. reactiva Alstrup \& D. Hawksw., which was collected from Hymenelia lacustris (Hymeneliaceae) in Greenland. The genus was placed in Dothideales, but was unusual in that the apex of the internal apical asci were $\mathrm{J}^{+}$, with a cylindrical annulus (Alstrup \& Hawksworth 1990). Therefore, Alstrup \& Hawksworth (1990) tentatively placed the genus in Dacampiaceae based on its cellular pseudoparaphyses. Etayo \& Sancho (2008) treated Kalaallia as a synonym of Opegrapha and thus a new combination, Opegrapha reactiva was proposed, despite the presence of perithecia. The species is distributed in Chile, Greenland, UK and Luxembourg (Coste 2014).

Opegrapha reactiva (Alstrup \& D. Hawksw.) Etayo \& Diederich, Biblthca Lichenol. 98: 159 (2008)

$\equiv$ Kalaallia reactiva Alstrup \& D. Hawksw., Meddr Grønland, Biosc. $31: 39$ (1990)

Index Fungorum number: IF536940; Facesoffungi number: FoF03685

Fig. 77

Lichenicolous on Hymenelia lacustris (With.) M. Choisy. Sexual morph: Ascomata 70-200 $\mu \mathrm{m}$ diameter $\times$ 110-150 $\mu \mathrm{m}$ high, [Alstrup \& Hawksworth (1990): (50-)60-100 $\mu \mathrm{m}$ diameter], perithecial, arising in loose groups, forming patches up $0.2 \mathrm{~mm}$ diameter, black, immersed to erumpent on the host thallus, globose to subglobose, gregarious, ostiole discrete to gaping, with apical pore. Peridium 6-25 $\mu \mathrm{m}$ wide, unequally thick, apically thickened [Alstrup \& Hawksworth 1990: reaching to $40 \mu \mathrm{m}$ diameter], loose hyphae of brown to dark brown pseudoparenchymatous cells, somewhat olivaceous in $5 \% \mathrm{KOH}$, arranged in a textura porrecta. Hamathecium comprising 1-2 $\mu \mathrm{m}$ wide, dense, branched, distinctly septate, anastomosed, cellular pseudoparaphyses, with $\mathrm{I}^{+}$, pale blue centrum. Asci (57-)60-76 $\times(9-) 10-12(-14) \mu \mathrm{m}(\bar{x}=65 \times 11 \mu \mathrm{m}, \mathrm{n}=10)$ [Alstrup \& Hawksworth (1990): 55-65 × 10-12 $\mu \mathrm{m}], 8$-spored, bitunicate, clavate to cylindric-clavate, with short pedicel, apex rounded, with well-developed ocular chamber, apically thickened. Ascospores $(8-) 9-13(-14) \times 2.5-3.5(-4) \mu \mathrm{m}(\bar{x}=11 \times 3 \mu \mathrm{m}, \mathrm{n}=15)$ [Alstrup \& Hawksworth (1990): (17.5)20-24 $\times 5-7 \mu \mathrm{m}]$, overlapping 2-3-seriate, hyaline or yellowish when stained by Lugol's iodine, ellipsoidal to fusiform, with round to acute ends, 1-3-septate, sometimes constricted at the septa, smooth-walled. Asexual morph: Undetermined.

Material examined - GREENLAND, Norssay District, Alangorssuaq, altitude $70 \mathrm{~m}$., on Hymenelia lacustris (With.) M. Choisy (Hymeneliaceae), 3 August 1980, V. Alstrup 801282 (IMI331017, ex herb. = K (M) 177966 slide, holotype). 


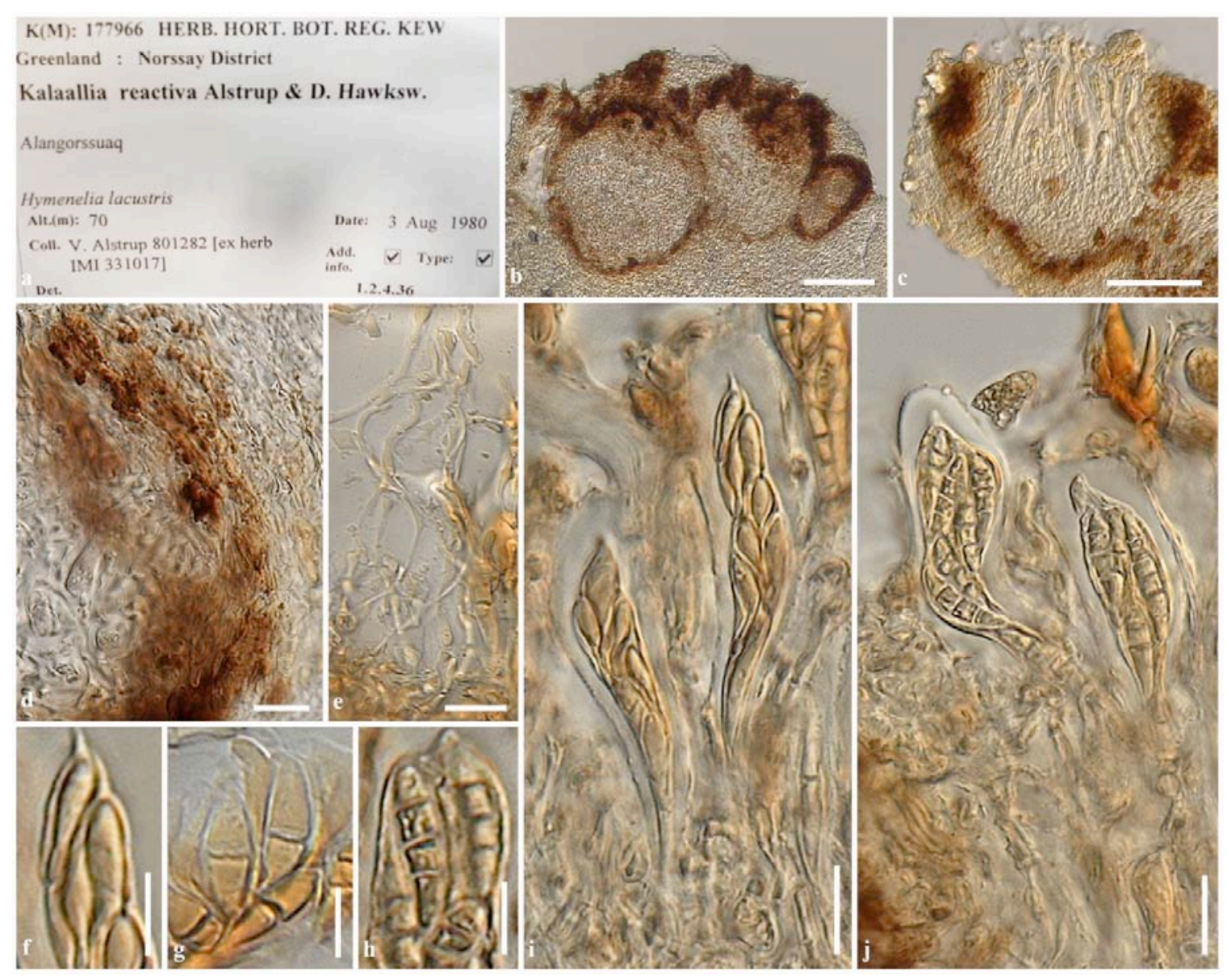

Figure 77 - Opegrapha reactiva (K (M) 177966, holotype). a Label of specimen. b, c Sections of ascomata. d Peridium. e Pseudoparaphyses. f-h Ascospores. i, j Asci. Scale bars: b, $\mathrm{c}=100 \mu \mathrm{m}, \mathrm{d}$, $\mathrm{e}, \mathrm{i}, \mathrm{j}=10 \mu \mathrm{m}, \mathrm{f}-\mathrm{h}=5 \mu \mathrm{m}$.

Parmulariaceae E. Müll. \& Arx ex M.E. Barr

In their phylogenetic analysis, Parmularia species represented a monophyletic clade outside Asterinales sensu stricto (Hyde et al. 2016). However, more sequence data are needed to confirm the placement of this family.

Inocyclus Theiss. \& Syd., Annls mycol. 13(3/4): 211 (1915)

Epifoliar on surface of living leaves. Sexual morph: Ascostromata superficial, appearing as black circular domes, solitary to clustered, globose to subglobose, comprising multi-locules, dark brown to black. Peridium comprising 2 layers of dark brown cells of textura oblita, outer layer composed thick and pigmented, inner layer thin and hyaline. Asci 8-spored, bitunicate, cylindrical to obovoid with short and rounded pedicel, with ocular chamber. Ascospores 1-septate, ovoid with upper cell broader and longer, slightly constricted and pale brown to brown at the septum, surface of spore smooth, hyaline when immature and pale brown to brown at maturity. Asexual morph: Undetermined.

Type species - Inocyclus psychotriae (Syd. \& P. Syd.) Theiss. \& Syd.

Notes - Inocyclus was introduced by Theiss and Sydow (1915), with the type species $I$. psychotriae. The genus was accepted in Parmulariaceae based on morphological characters (Guatimosim et al. 2014). Inocyclus differs from Polycyclus in having a gelatinous ascal layer with a strong amyloid reaction, and irregularly or radially arranged locules. Inácio and Cannon (2008) designated specimens of I. psychotriae in $\mathrm{K}$ as lectotype, and in NY as isolectotype because the type material has not been seen. Guatimosim et al. (2015) used sequence data of $I$. angularis in their phylogenetic tree and concluded that the phylogeny of Inocyclus in Parmulariaceae is 
unresolved because sequence data of type species is unavailable. The morphology of I. psychotriae (Fig. 78) differs from I. angularis by having hypophyllous, with verrucous surface ascomata, uniseptate at the lower part of ascospores, while I. angularis has amphigenous ascomata, locules arranged in one-two rings, with an undulated surface, uniseptate at the centre of the ascospores. Inocyclus angularis is quite different from other species in Inocyclus (Inácio and Cannon 2008), and it might be not a species in this genus. Inocyclus is somewhat similar to Mendogia Racib., it however differs from Mendogia in having superficial external ascostromata, with radiating cells, uniseptate ascospores. Mendogia has carbonaceous ascostromata, muriform ascospores (Dai et al. 2017). Phylogenetic analysis in Hyde et al. (2016) indicated that I. angularis strains were within Asterinales sensu stricto and sister to Asterotexis species. Base on the morphological differences between $I$. angularis and type species, and unavailability of sequence data of type species, we therefore suggest the placement of Inocyclus in Parmulariaceae. However, a fresh collection of $I$. psychotriae (type species) is needed to clarify the correct placement of this genus.

Inocyclus psychotriae (Syd. \& P. Syd.) Theiss. \& Syd. 1915

$\equiv$ Hysterostomella psychotriae Syd. \& P. Syd., Philipp. J. Sci., C, Bot. 8(4): 275 (1913)

= Dielsiella psychotriae (Syd. \& P. Syd.) Hansf., Mycol. Pap. 15: 170 (1946)

Index Fungorum number: IF174208; Facesoffungi number: FoF03712

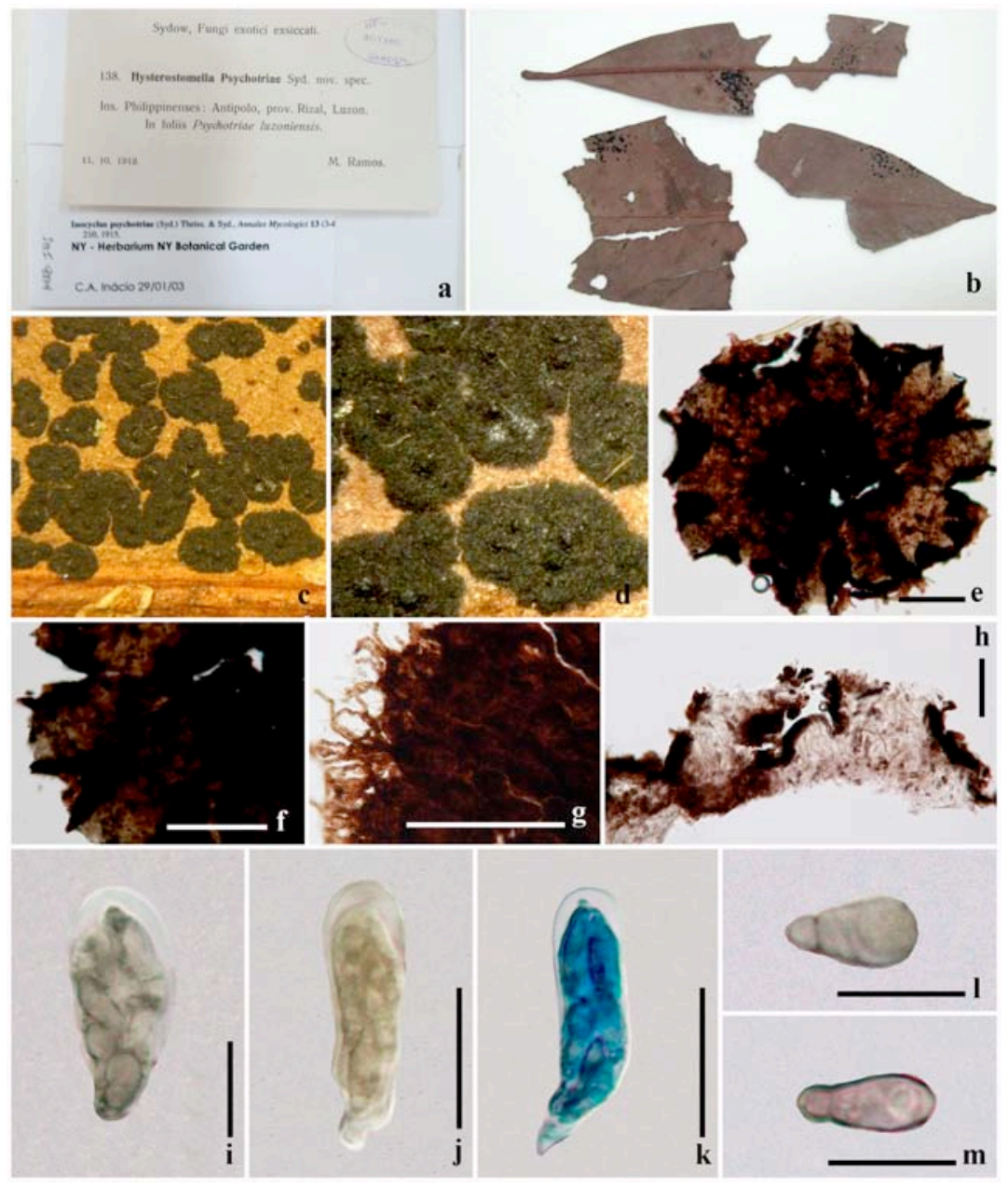

Figure 78 - Inocyclus psychotriae (NY 01840454, isolectotype). a, b Herbarium specimen and habit on leaves. c, d Appearance of ascostromata with locules at the center on leaf surface. e Squash mount of ascostromata. f, g Structure of ascostromata from above and below. $\mathrm{h}$ Section of ascostromata. i Asci at maturity. $\mathrm{j}$ Asci in Melzer's reagent. $\mathrm{k}$ Asci in Cotton blue reagent. 1 Ascospore in Melzer's reagent. $\mathrm{m}$ Ascospore in 70\% Lactic acid. Scale bars: $\mathrm{e}-\mathrm{g}=100 \mu \mathrm{m}, \mathrm{h}=50$ $\mu \mathrm{m}, \mathrm{i}-\mathrm{k}=20 \mu \mathrm{m}, 1, \mathrm{~m}=10 \mu \mathrm{m}$. 
Epifoliar on surface of living leaves of Psychotria luconiensis (Cham. \& Schltd1.) Fern.-Vill. Sexual morph: Ascostromata 78-87 $\mu \mathrm{m}$ diameter $\times 520-579 \mu \mathrm{m}$ high, superficial, appearing as black domes, solitary to clustered, globose to subglobose, comprising multi-locules, dark brown to black. Peridium comprising 2 layers of dark brown cells of textura oblita, outer layer thick and pigmented, inner layer thin and hyaline. Asci $28-38 \times 8-10 \mu \mathrm{m}(\bar{x}=32 \times 9 \mu \mathrm{m}, \mathrm{n}=10), 8$-spored, bitunicate, cylindrical to obovoid, with short and rounded pedicel, with ocular chamber. Ascospores 9-11 $\times 3-4 \mu \mathrm{m}(\bar{x}=10 \times 3 \mu \mathrm{m}, \mathrm{n}=10)$, uniseptate, ovoid with upper cell broader and longer, slightly constricted and pale brown to brown at the septum, surface of spore smooth, hyaline when immature and pale brown to brown at maturity. Asexual morph: Undetermined.

Material examined - PHILIPPINES, Luzon, Rizal, Antipolo, on leaves of Psychotria luconiensis (Cham. \& Schltdl.) Fern.-Vill. (Rubiaceae), 11 October 1912, M. Ramos, no. 138 (NY 01840454, isolectotype).

\section{Perisporiopsidaceae E. Müll. \& Arx ex R. Kirschner \& T.A. Hofm.}

(= Parodiopsidaceae Toro)

Parasitic on living leaves of various plants. Sexual morph: Ascomata superficial, gregarious, solitary, seated on a subiculum, globose to subglobose, obovoid, brown, with apical ostiole. Peridium relatively thick-walled, comprising dark brown cells of textura angularis. Hamathecium comprising 4-5 $\mu \mathrm{m}$, branched, septate, anastomosed, hyaline pseudoparaphyses. Asci 8-spored, bitunicate, fissitunicate, broadly ellipsoid, apically thickened, with an ocular chamber, short pedicellate. Ascospores 2-3-seriate, ellipsoidal-oblong or fusiform, slightly curved and tapering toward the ends, 1-septate, hyaline, sometimes pale-yellow brown, with granulate cells, smoothwalled. Asexual morph: Undetermined.

Family type - Perisporiopsis Henn.

Notes - Perisporiopsidaceae comprises species occur on living leaves, with superficial ascomata with surrounding mycelia, and ellipsoidal oblong, 1 or more septate, hyaline ascospores (Hyde et al. 2013). We accept three genera Chevalieropsis, Parodiellina and Perisporiopsis in the family.

Parodiellina P. Henn. ex G. Arnaud, Annals d'École National d'Agric. de Montpellier, Série 2 16(1-4): 21 (1918) [1917]

Parasitic on the lower surface of living leaves. Colonies large, superficial, circular to subcircular, comprised of numerous ascomata, on brown to dark brown spots. Sexual morph: Ascomata superficial, seated on subiculum, unilocular, globose to subglobose, thick at the base, solitary to gregarious, dark brown to black, pore central, surrounded by dark brown setae, septate, sometimes branched at the base. Peridium compressed, comprising dark brown cells of textura angularis. Hamathecium comprising wide, septate, hyaline to pale brown, sparse pseudoparaphyses. Asci 8-spored, bitunicate, broadly obovoid to subclavate, thick-walled, pedicellate. Ascospores oval to ellipsoid, obovoid-clavate, aseptate, hyaline to light brown, smoothwalled. Asexual morph: hyphomycetous, sporodochial, with phragmosporous conidia. Colonies large, superficial, circular to subcircular, clustered, comprised of numerous sporodochia, as dark brown spots. Sporodochia superficial, pulvinate, cushion-like, clustered, dark brown, with erect setae, branched at the base, septate, dark brown. Conidiophores erect, mononematous, macronematous, thick-walled, unbranched, septate, hyaline, pale brown to dark brown, smoothwalled, arranged in the sporodochia in a palisade manner. Conidiogenous cells ellipsoid, pale to moderately brown, holoblastic to annellidic, with conspicuous annellations. Conidia solitary, ellipsoidal to clavate, truncate at the base, apex rounded, hyaline, becoming brown to red brown when mature, 2-euseptate, constricted at the septa, smooth-walled.

Type species - Parodiellina manaosensis (Henn.) G. Arnaud

Notes - Parodiellinaceae and Parodiellina were introduced by Arnaud (1918) to accommodate a species distinguished from the genus Parodiella Henn. The genus is typified by Parodiellina manaosensis (= Parodiella manaosensis Henn.) which was described by Hennings 
(1904). The genus is characterized by oval to ellipsoid, obovoid-clavate, aseptate ascospores and a conspicuous sporodochial asexual morph. Aseptate ascospores and conidial features differ from all genera in Perisporiopsidaceae (= Parodiopsidaceae). Parodiellina has been placed in various families and orders based on characters of ascomata, ascospores and the asexual morph (Gäumann \& Dodge 1928, Hansford 1946, Müller \& von Arx 1950). The proposed family name Parodiellinaceae is invalid (ICBN Art. 32.1(c) and Art. 36.1, Index Fungorum 2017). Luttrell (1955) re-visited the type species of Parodiellina (P. manaosensis) and placed the genus in the family Perisporiopsidaceae based on its bitunicate asci. Lumbsch \& Huhndorf (2010) included Parodiellina in the family Parodiopsidaceae (current name Perisporiopsidaceae). However, Parodiellina has dark ascomata, broadly obovoid to subclavate, thick-walled asci and aseptate, oval to ellipsoid, hyaline ascospores. Therefore, Parodiellina can be placed in the family Perisporiopsidaceae.

Parodiellina manaosensis (Henn.) G. Arnaud, Annals d'École National d'Agric. de Montpellier, Série 2 16(1-4): 21 (1918) [1917]

三 Parodiella manaosensis Henn., Hedwigia 43: 358 (1904)

= Parodiopsis manaosensis (Henn.) Arnaud, Bull. Soc. Mycol. France: 23 (1915)

= Auerswaldiella manaosensis (Henn.) Arx \& E. Müll., Beiträge zur Kryptogamenflora der Schweiz 11 (1): 67 (1954)

Index Fungorum number: IF222829; Facesoffungi number: FoF03686 Figs 79, 80

Parasitic on the lower surface of living leaves of Solanaceae. Colonies large, superficial, circular to subcircular, comprised of numerous ascomata, on brown to dark brown spots. Sexual morph: Ascomata 200-250 $\mu \mathrm{m}$ diameter, superficial, seated on a subiculum, unilocular, globose to subglobose, thick at the base, solitary to gregarious, dark brown to black, pore central, surrounded by dark brown setae, $88(-137)-255 \mu \mathrm{m}$ long $\times 5-8 \mu \mathrm{m}$ wide, septate, sometimes branched at the base. Peridium 40-50 $\mu \mathrm{m}$ wide, comprising dark brown cells of textura angularis. Hamathecium comprising wide, septate, hyaline to pale brown, obscure pseudoparaphyses. Asci 137-158.5 × 33$47 \mu \mathrm{m}(\bar{x}=148 \times 37 \mu \mathrm{m}, \mathrm{n}=10), 8$-spored, bitunicate, broadly obovoid to subclavate, thickwalled, pedicellate. Ascospores 38-52 $\times 13-16 \mu \mathrm{m}(\bar{x}=43 \times 14 \mu \mathrm{m}, \mathrm{n}=10)$, oval to ellipsoid, obovoid-clavate, aseptate, hyaline to light brown, smooth-walled. Asexual morph: hyphomycetous. Colonies large, superficial, circular to subcircular, clustered, comprised of numerous sporodochia, on dark brown spots. Conidiomata sporodochial, 600-985(-1,330) $\mu \mathrm{m}$ diameter, superficial, cushion-like, clustered, dark brown, with erect setae, 110-278 $\mu \mathrm{m}$ long $\times 6-8.5 \mu \mathrm{m}$ wide, branched at the base, septate, dark brown. Conidiophores 34-56 $\mu \mathrm{m} \times 8-8.5 \mu \mathrm{m}(\bar{x}=42 \times 8 \mu \mathrm{m}, \mathrm{n}=10)$, erect, mononematous, macronematous, thick-walled, unbranched, septate, hyaline, pale brown to dark brown, smooth-walled, arranged in the sporodochia in a palisade manner. Conidiogenous cells ellipsoid, pale to moderately brown, holoblastic to annellidic, with conspicuous annellations. Conidia 49-60 $\times 14-18 \mu \mathrm{m}(\bar{x}=55 \times 17 \mu \mathrm{m}, \mathrm{n}=10)$, solitary, ellipsoidal to clavate, truncate at the base, apex rounded, hyaline, becoming brown to red brown when mature, 2-euseptate, constricted at the septa, smooth-walled.

Material examined - BRAZIL, Amazonas, Manaus (= Manáos), Rio Negro, on living leaves of Solanaceae Juss., January 1901, E.H.G. Ule No. 3027 (PC0084489, holotype = B700014750, syntype).

\section{Perisporiopsis Henn. Hedwigia 43(2): 83 (1904)}

Parasitic on living leaves. Sexual morph: Ascomata superficial, solitary to gregarious, seated on a subiculum, globose to subglobose, obovoid, brown, with apical ostiole. Peridium relatively thick-walled, comprising dark brown cells of textura angularis. Hamathecium comprising branched, septate, anastomosed, hyaline, pseudoparaphyses. Asci 8-spored, bitunicate, fissitunicate, broadly ellipsoid, with short pedicel, apically thickened, with an ocular chamber. Ascospores 2-3seriate, ellipsoidal-oblong or fusiform, slightly curved and tapering toward the ends, 1-septate, 
hyaline, sometimes pale-yellow brown, with granulate cells, smooth-walled. Asexual morph: Undetermined. (Kirk et al. 2008, Seifert et al. 2011).

Type species - Perisporiopsis struthanthi Henn.

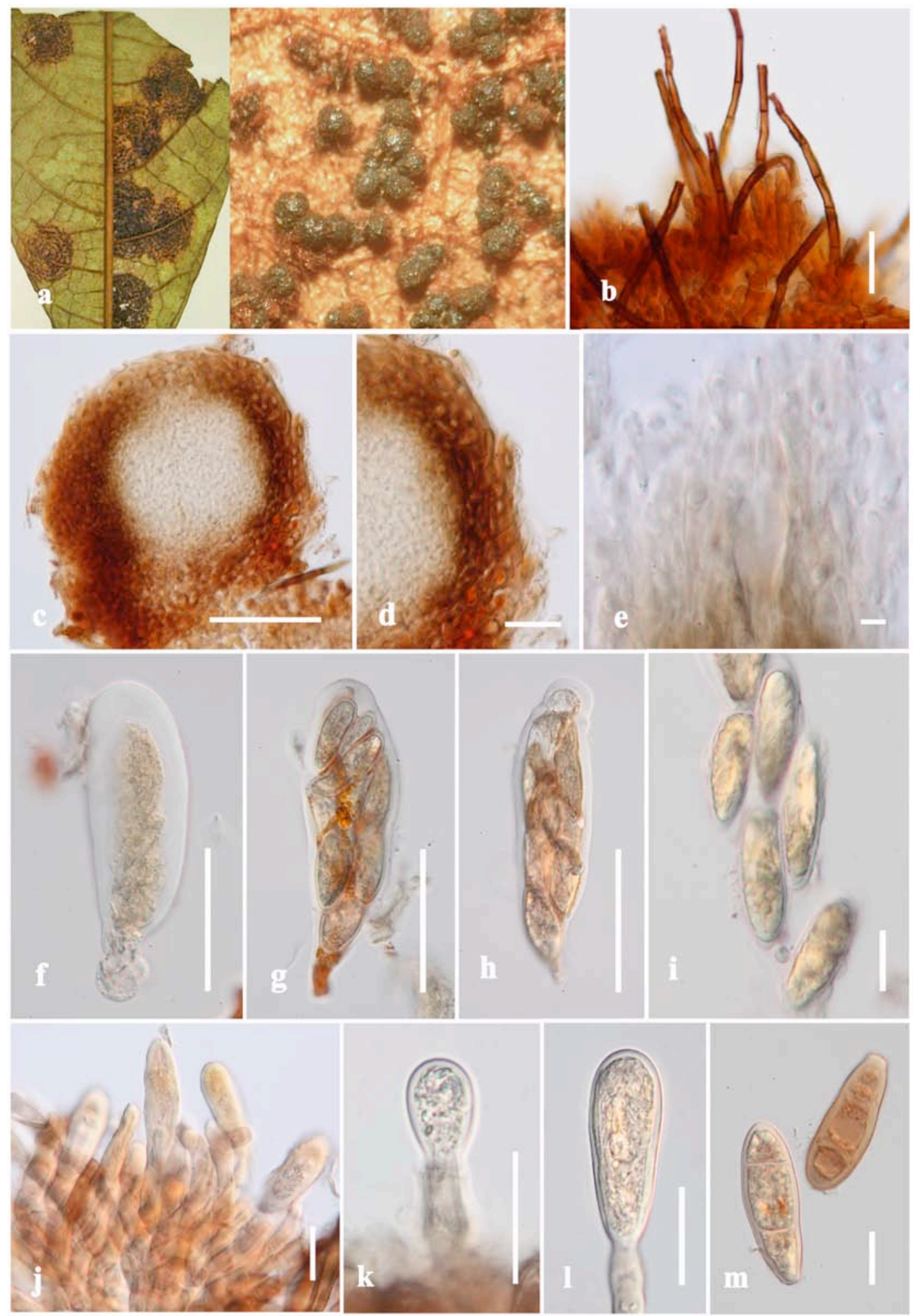

Figure 79 - Parodiellina manaosensis (PC0084489, holotype). a Appearance of colonies on lower leaf surface, ascomata and habit on leaf. b Setae. c Section of ascoma. d Peridium. e Obscure pseudoparaphyses. $\mathrm{f}-\mathrm{h}$ Asci. i Ascospores. $\mathrm{j}$ Conidiophores. $\mathrm{k}, 1$ Close up of conidiophores and conidia. $\mathrm{m}$ Conidia. Scale bars: $\mathrm{a}=500 \mu \mathrm{m}, \mathrm{b}, \mathrm{d}, \mathrm{f}-\mathrm{h}, \mathrm{l}=50 \mu \mathrm{m}, \mathrm{c}=100 \mu \mathrm{m}, \mathrm{e}=5 \mu \mathrm{m}, \mathrm{i}-\mathrm{k}, \mathrm{m}=20$ $\mu \mathrm{m}$. 

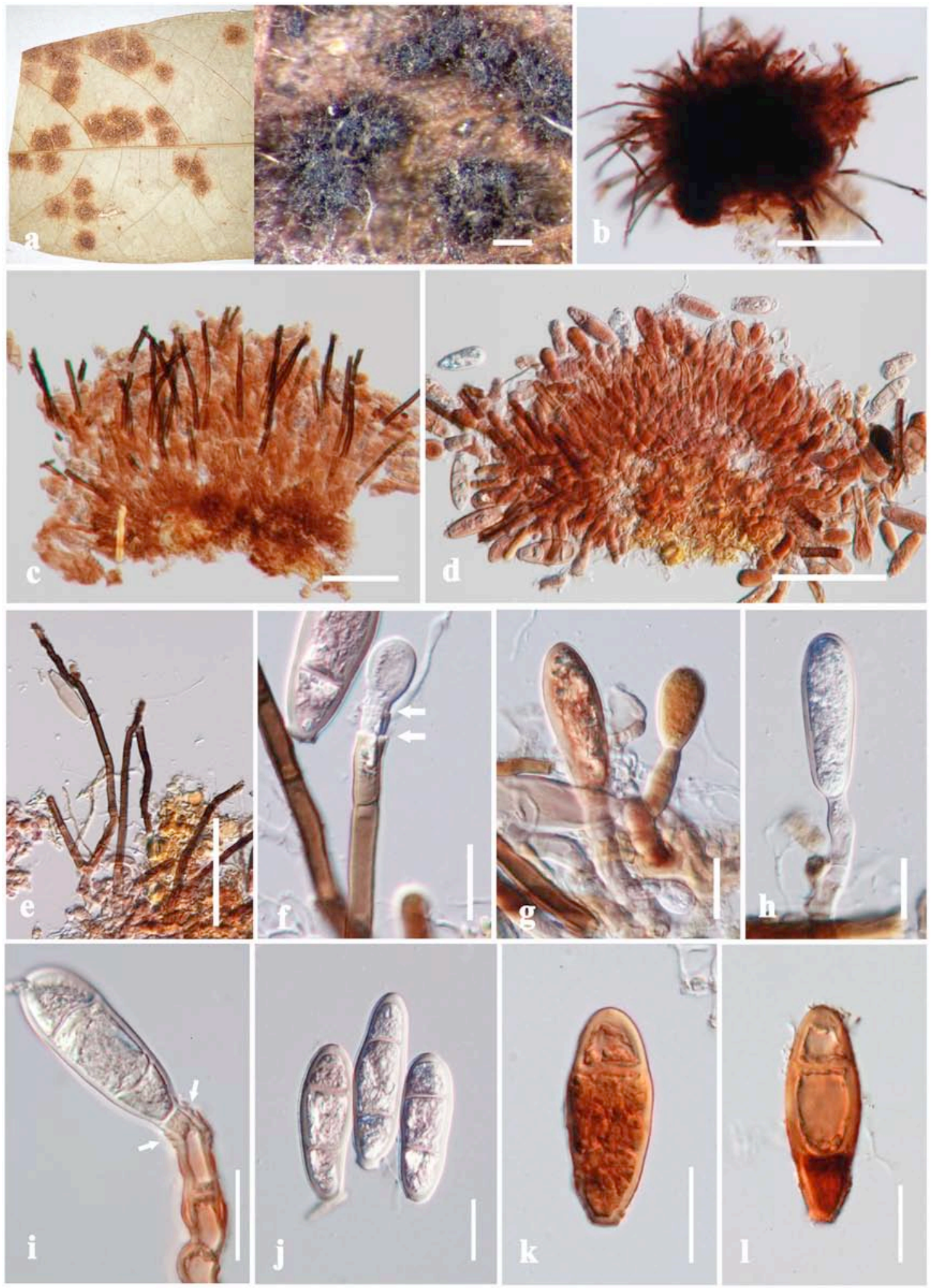

Figure 80 - Asexual morph of Parodiellina manaosensis (B700014750, syntype). a Appearance of colonies and sporodochia on lower leaf surface. b Squash mount of sporodochium. $c-d$ Section of sporodochium. e Setae. f Conidiogenous cell with annellations and developing conidium at the apex. g, h Immature conidia. i Detail of apical conidiophore and conidium (annellation as arrows). $\mathrm{j}-1$ Conidia. Notes: Conidia and tissues changed to pinkish in $5 \% \mathrm{KOH}$ (in Figs $f$ and $\mathrm{j}$ ). Scale bars: $\mathrm{a}, \mathrm{b}=200 \mu \mathrm{m}, \mathrm{c}-\mathrm{e}=100 \mu \mathrm{m}, \mathrm{f}-\mathrm{l}=20 \mu \mathrm{m}$.

Notes - Hyde et al. (2013) examined, illustrated and described the holotype specimen of Perisporiopsis struthanthi Henn. (PC0084481) and used the family name Perisporiopsidaceae 
following Kirschner et al. (2010), while Parodiellinaceae and Parodiopsidaceae were suggested to be synonyms of Perisporiopsidaceae. The genus is characterized by superficial dark ascomata, lacking hyphopodia, indistinct pseudoparaphyses, broadly clavate asci and ellipsoidal oblong, septate, hyaline ascospores. Currently, Index Fungorum (2017) lists 20 epithets under Perisporiopsis. The asexual morph was referred to the genus Septoidium (Eriksson 1981, Kirk et al. 2008, Seifert et al. 2011), but we could not find the asexual morph on the type specimen. Epitypification and molecular sequence data are needed to determine the phylogenetic placement of the family in Dothideomycetes.

Perisporiopsis struthanthi Henn., Hedwigia 43: 83 (1904)

= Parodiopsis struthanthi (Henn.) G. Arnaud, Annls Épiphyt. 7: 54 (1921)

= Perisporina struthanthi (Henn.) Hansf., Proc. Linn. Soc. London 157: 144 (1946)

Index Fungorum number: IF216818; Facesoffungi number: FoF03687

Fig. 81

Parasitic on living leaves of Struthanthus sp. Sexual morph: Ascomata 263.5-272 $\mu \mathrm{m}$ diameter $\times 257-267.5(-366.5) \mu \mathrm{m}$ high, superficial, solitary to gregarious, seated on a subiculum, globose to subglobose, obovoid, brown, with apical ostiole. Peridium (34-)40-46 $\mu \mathrm{m}$ wide, relatively thick-walled, comprising dark brown cells of textura angularis. Hamathecium 4-5 $\mu \mathrm{m}$, comprising branched, septate, anastomosed, hyaline, pseudoparaphyses. Asci (121-)141-157(-171) $\times 32-45(-49) \mu \mathrm{m}(\bar{x}=145 \times 41 \mu \mathrm{m}, \mathrm{n}=10), 8$-spored, bitunicate, fissitunicate, broadly ellipsoid, with short pedicel, apically thickened, with an ocular chamber. Ascospores 52.5-62 $\times 9-13 \mu \mathrm{m}(\bar{x}$ $=56 \times 12 \mu \mathrm{m}, \mathrm{n}=10), 2-3$-seriate, ellipsoidal-oblong or fusiform, slightly curved and tapering toward the ends, 1-septate, hyaline, sometimes pale-yellow brown, with granulate cells, smoothwalled. Asexual morph: Undetermined. Notes: The asexual morph as described in Eriksson (1981) was not observed.

Material examined - BRAZIL, Rio de Janeiro, Estado de Rio de Janeiro, Serra dos Orgaos, on leaves of Struthanthus sp. (Apocynaceae), August 1899, E.H.G. Ule No. 2631 (S-F9814, holotype).

Chevalieropsis G. Arnaud, Annls Épiphyt. 9: 2 (1923)

Parasitic on living leaves. Sexual morph: Stromata up to $1 \mathrm{~mm}$ diameter, comprising more than 10 ascomata, clustered to solitary, semi-immersed and thick at the base, asexual morph possibly associated with dark brown conidiophores, minutely multi-denticulate, with subglobose and hyaline, septate, unbranched conidia, pale at the apex, and darkened and wider at the base. Ascomata superficial, grouped, subglobose, uniloculate, dark brown, formed in a stroma, with a subiculum, slightly substipitate, thickened base. Peridium comprising hyaline to dark brown cells of textura angularis. Asci 8-spored, bitunicate, obovoid, obpyriform to clavate, sessile or with short pedicel, thick-walled and multi-layer at the apex, with small ocular chamber. Ascospores 2-3seriate, obovoid, apex wider, narrower towards the lower and pointed base, 1-4-septate, slightly constricted at the septum, hyaline to pale brown or reddish-brown, sometimes guttulate, slightly verruculose. Asexual morph: Septoidium sp.

Type species - Chevalieropsis ctenotricha (Pat. \& Har.) G. Arnaud

Notes - Arnaud (1923) introduced the monotypic genus Chevalieropsis with the type species C. ctenotricha which is recognized by superficial ascostromata, with thick-walled asci and 1-4septate, hyaline to pale brown ascospores. Moreau \& Moreau (1955) described two types of asexual conidia associated with $C$. ctenotricha on leaves of Daniella oliveri (Detarioideae), which were similar to species in the genus Septoidium. Sivanesan (1984) re-examined and described $C$. ctenotricha and its asexual conidia, and found this species differed from Perisporiopsis lophirae in the number of septa. Eriksson (1999) included Chevalieropsis in Parodiopsidaceae and treated it as order incertae sedis. Hyde et al. (2013) revised the family which is characterized by "occurrence on living leaf surfaces as mycelium with superficial ascomata", therefore the genus should be placed in Perisporiopsidaceae (= Parodiopsidaceae). 


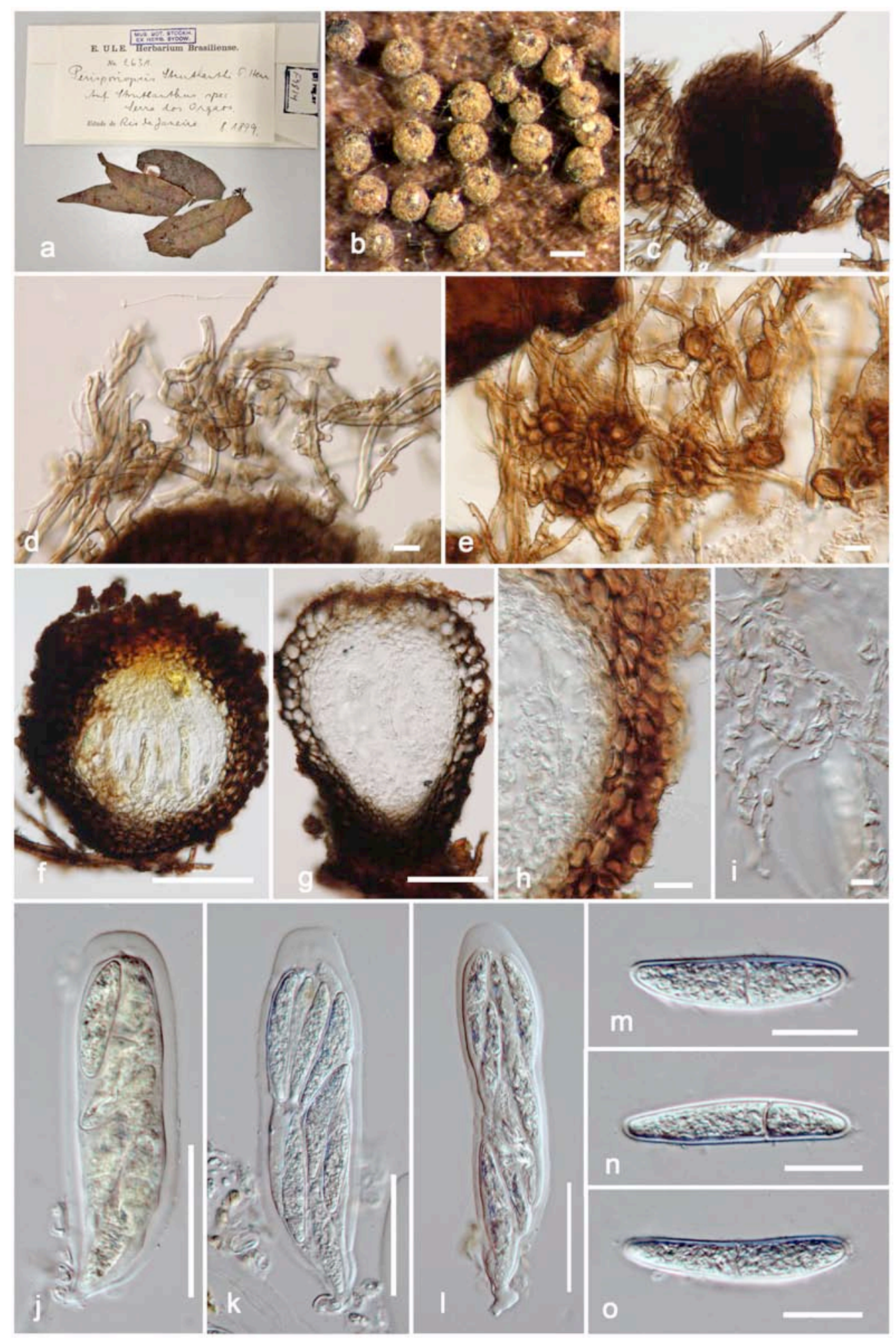

Figure 81 - Perisporiopsis struthanthi (S-F9814, holotype). a Herbarium specimen and habit on leaves. b Appearance of ascomata on leaf surface. $\mathrm{c}-\mathrm{e}$ Squash mount of ascoma and mycelium. $\mathrm{f}-\mathrm{g}$ Sections of ascoma. $h$ Peridium. i Pseudoparaphyses. $j-1$ Asci. $m-0$ Ascospores. Scale bars: $b=200$ $\mu \mathrm{m}, \mathrm{c}, \mathrm{f}, \mathrm{g}=100 \mu \mathrm{m}, \mathrm{d}, \mathrm{e}=10 \mu \mathrm{m}, \mathrm{h}, \mathrm{m}-\mathrm{o}=20 \mu \mathrm{m}, \mathrm{j}-1=50 \mu \mathrm{m}$.

Chevalieropsis ctenotricha (Pat. \& Har.) G. Arnaud, Annls Épiphyt. 9: 2 (1923)

$\equiv$ Dimerosporium ctenotrichum Pat. \& Har., J. Bot., Paris 14: 242 (1900)

$\equiv$ Phaeodimeriella ctenotricha (Pat. \& Har.) Speg., Revta Mus. La Plata 15(2): 13 (1908)

$\equiv$ Chevalieria ctenotricha (Pat. \& Har.) G. Arnaud, C. r. hebd. Séanc. Acad. Sci., Paris 170: 203 (1920) Index Fungorum number: IF251673; Facesoffungi number: FoF03688

Fig. 82 


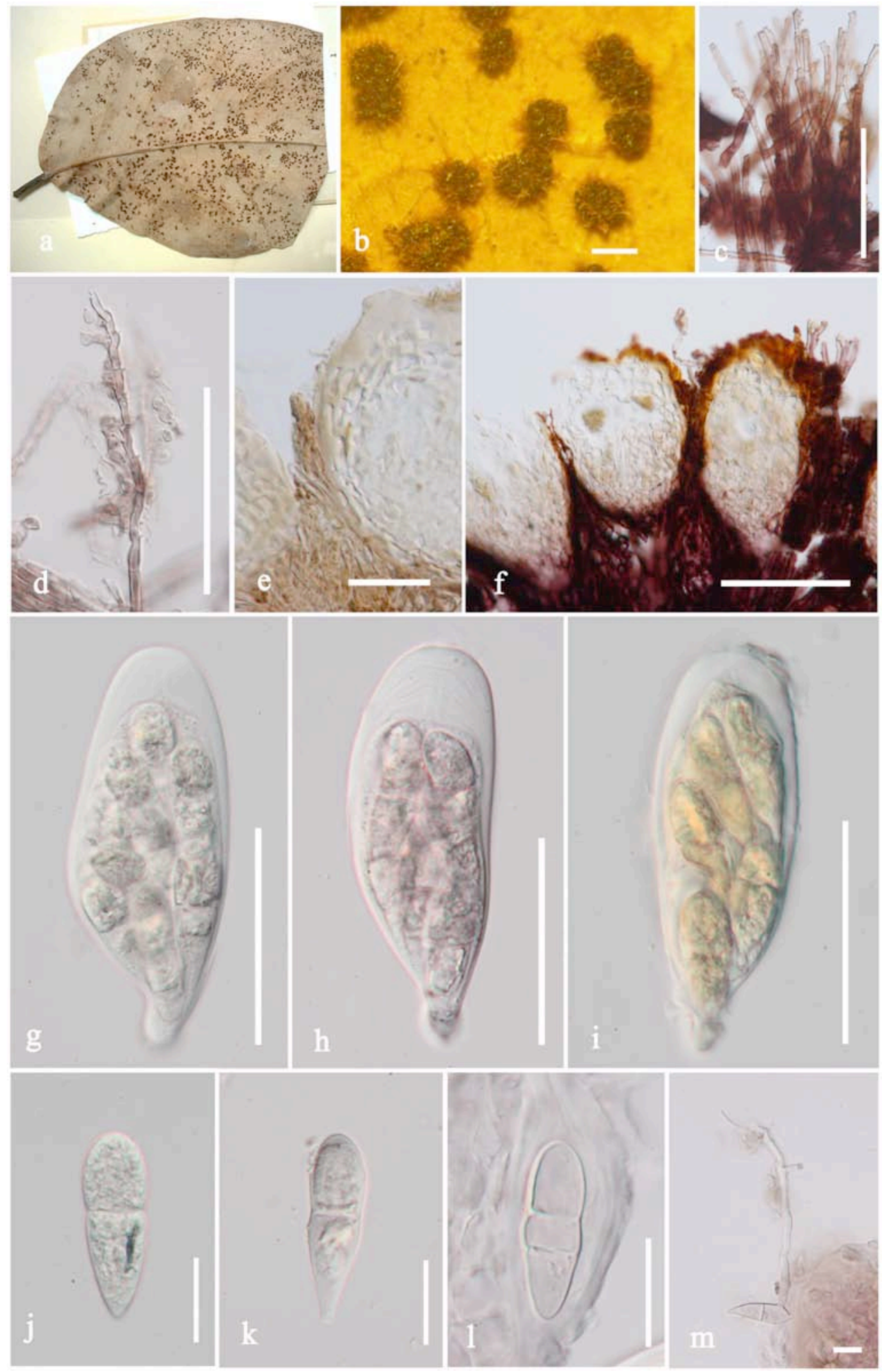

Figure 82 - Chevalieropsis ctenotricha (PC0084492, holotype). a Herbarium specimen and habit on leaf. b Appearance of ascostromata on leaf surface. c. Conidiophores. d Conidiophore and conidia. e Peridium. f Section of ascostroma. $g-i$. Asci. $j-1$. Ascospores. $m$ Germ tube of ascospore. Scale bars: $\mathrm{b}=500 \mu \mathrm{m}, \mathrm{c}, \mathrm{d}, \mathrm{f}=100 \mu \mathrm{m}, \mathrm{e}, \mathrm{g}-\mathrm{i}=50 \mu \mathrm{m}, \mathrm{j}-\mathrm{m}=20 \mu \mathrm{m}$.

Parasitic on living leaves of Bignonia sp. Sexual morph: Ascostromata up to $1 \mathrm{~mm}$ diameter, comprising more than 10 ascomata, clustered to solitary, semi-immersed and thick at the base, asexual morph possibly associated with dark brown conidiophores, 5-7(-15) $\mu \mathrm{m}$ diameter $\times 160$ 236(-355) $\mu \mathrm{m}$ long, minutely conidia, multi-denticulate, subglobose and hyaline, 4-5.5 $\mu \mathrm{m}$ diameter, septate, unbranched, pale at the apex, darkened and base wider. Ascomata 169-187(-197) 
$\mu \mathrm{m}$ diameter $\times(149-) 155-180(-198) \mu \mathrm{m}$ high, superficial, grouped, subglobose, uniloculate, dark brown, formed in a stroma, with a subiculum, slightly substipitate, thick at the base. Peridium 20.5-32 $\mu \mathrm{m}$ wide, comprising 3-4 layers of hyaline to dark brown cells of textura angularis. Asci 82-100(-115) × 34-40(-49) $\mu \mathrm{m}(\bar{x}=95 \times 40 \mu \mathrm{m}, \mathrm{n}=10), 8$-spored, bitunicate, obovoid, obpyriform to clavate, sessile or with short pedicel, thick-walled and multi-layered at the apex, with small ocular chamber. Ascospores 34-46.5 $\times 12.5-15 \mu \mathrm{m}(\bar{x}=41 \times 13.5 \mu \mathrm{m}, \mathrm{n}=10)$, 2-3-seriate, obovoid, apex wider, narrowing towards the lower and pointed base, 1-4-septate, slightly constricted at the septum, hyaline to pale brown or reddish-brown, sometimes guttulate, slightly verruculose. Asexual morph: Septoidium sp.

Material examined - SENEGAL, Casamance, Fogny, on leaves of Bignonia sp. (Bignoniaceae), 1898/1900, A. Chevalier (MNHN-PC-PC0084492, holotype, FH00301204, ex 7588 , isotype).

Phaeodimeriellaceae Boonmee, Mapook \& K.D. Hyde, fam. nov.

Index Fungorum number: IF553833; Facesoffungi number: FoF03689

Epiphytes on living leaves, or associated with other fungi on leaves. Sexual morph: Ascomata superficial, solitary or scattered, coriaceous, globose to subglobose, dark brown, surrounded by brown to dark brown mycelium at the base, with apical ostiole, with hook-like and dark brown setae. Peridium comprising brown to dark brown cells of textura angularis. Hamathecium comprising rather wide, cylindrical to filiform, branched, septate, pseudoparaphyses. Asci 8-spored, bitunicate, oval to ellipsoidal, apex rounded, short pedicellate, with a small ocular chamber. Ascospores 2-3-seriate, hyaline when immature and pale brown to brown at maturity, oblong to broadly fusiform, with a mucilaginous sheath. Asexual morph: Coelomycetous. Conidiomata pycnidial, superficial, globose to subglobose, with long, hook-like, aseptate, dark brown setae, with blunt apex. Peridium comprising brown cells of textura angularis. Conidiophores reduced to conidiogenous cells. Conidiogenous cells enteroblastic, monophialidic. Conidia fusiform, hyaline, aseptate, guttulate.

Family type - Phaeodimeriella Speg.

Notes - Phaeodimeriellaceae is introduced to accommodate Phaeodimeriella parvula, $P$. dilleniae and $P$. cissampeli, which are characterised by dark brown ascomata, with dark brown, hook-like setae and 1-septate, brown ascospores, connected to a coelomycetous asexual morph. Phaeodimeriella clustered in a strongly supported clade among the families in Dothideomycetes (see Fig. 1 in Mapook et al. 2016).

Phaeodimeriella Speg., Revta Mus. La Plata 15(2): 13 (1908)

三Dimerosporium occultum Racib., Parasit. Alg. Pilze Java's (Jakarta) 3: 32 (1900)

The genus was lectotypified by Phaeodimeriella occulta (Theissen 1912). Hansford (1946) synonymised $P$. occulta under $P$. parvula based on description following Cooke's type specimens of Dimerosporium parvulum Cooke. Mapook et al. (2016) introduced two new species based on morphological comparisons with the type material and multi-gene phylogenetic analyses. The phylogenetic tree showed that $P$. dilleniae and $P$. cissampeli clustered with the clade of Lentitheciaceae with moderate support. Phaeodimeriella differs from genera in Lentitheciaceae in having life mode as epiphytes on living leaves, superficial ascomata, hook-like setae and 1-septate, sometimes guttulate, rough-walled ascospores. For a detailed morphological description see Mapook et al. (2016).

Type species - Phaeodimeriella parvula (Cooke) Hansf., Mycol. Pap. 15: 64 (1946)

Index Fungorum number: IF289280; Facesoffungi number: FoF03690

Fig. 83

\section{Phaeosphaeriaceae M.E. Barr}

The classification follows Phookamsak et al. (2014), Ariyawansa et al. (2015), Liu et al. (2015), Hyde et al. (2016), Li et al. (2016) and Tibpromma et al. (2017). 


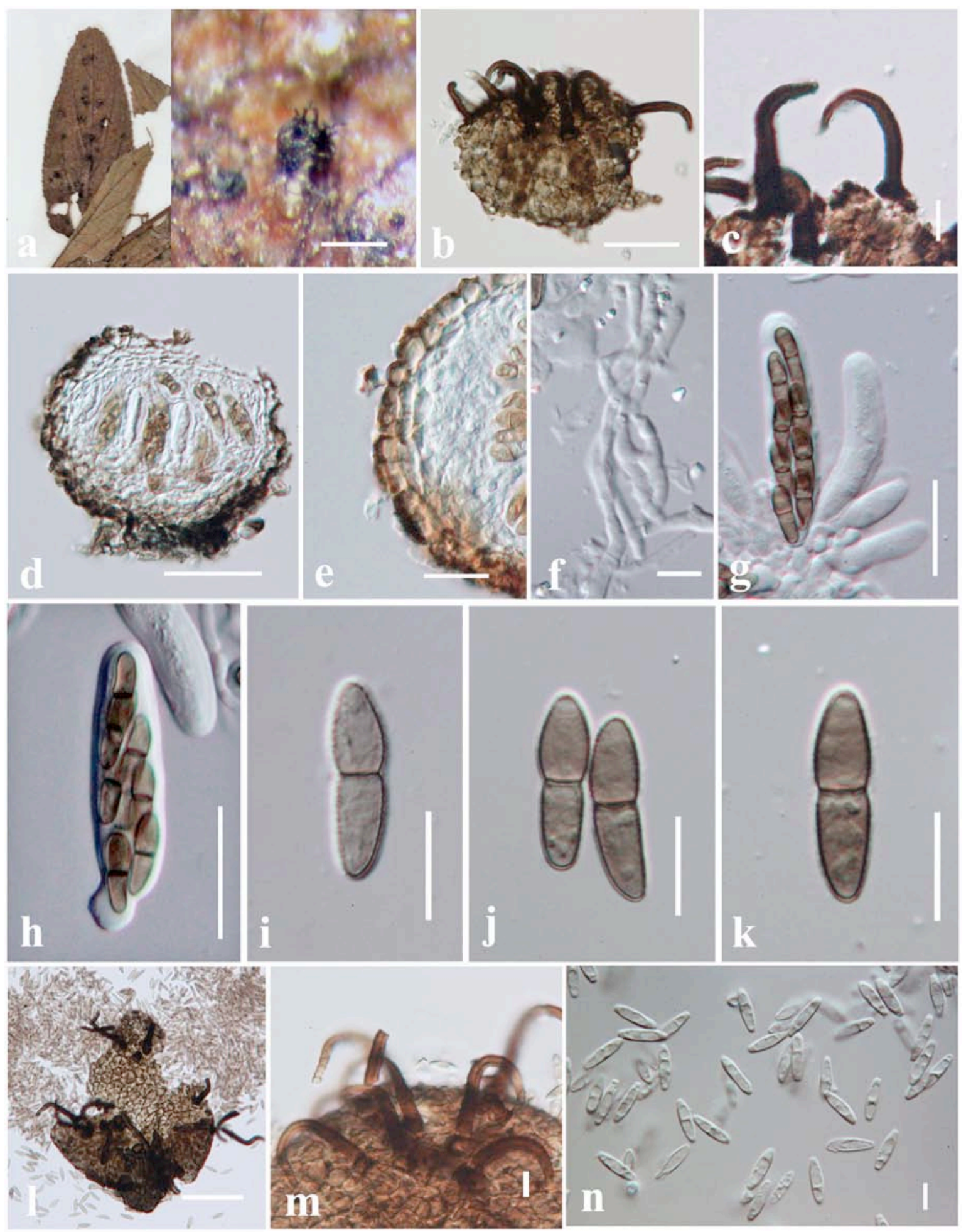

Figure 83 - Phaeodimeriella parvula (modified from Figures 2 and 3 in Mapook et al. 2016). a Herbarium specimen and habit on leaves. b Appearance of ascoma on leaf surface. c Setae. d Section of ascoma. e Peridium. f Hamathecium of pseudoparaphyses. g, h Asci. i-k Ascospores. 1 Section of conidioma. $\mathrm{m}$ Setae. $\mathrm{n}$ Conidia. Scale bars: $\mathrm{a}=100 \mu \mathrm{m}, \mathrm{b}, \mathrm{d}, \mathrm{m}=40 \mu \mathrm{m}, \mathrm{c}, \mathrm{e}, \mathrm{i}-\mathrm{k}=10$ $\mu \mathrm{m}, \mathrm{f}, \mathrm{n}=5 \mu \mathrm{m}, \mathrm{g}, \mathrm{h}=20 \mu \mathrm{m}, 1=50 \mu \mathrm{m}$.

Aphanostigme Syd., Annls mycol. 24(5/6): 368 (1926)

Parasitic on surface of living leaves. Sexual morph: Ascomata superficial, globose to subglobose, solitary, seated on dark brown hyphae, covered by dark brown setae, tapering towards subacute apex, septate, with apical ostiole. Peridium comprising 2-3 layers of dark brown cells of 
textura angularis. Hamathecium comprising numerous, branched, septate, hyaline, cylindrical to filiform pseudoparaphyses. Asci 8-spored, bitunicate, fissitunicate, oblong to cylindrical to clavate, with minute ocular chamber, pedicellate. Ascospores 2-seriate, cylindric fusiform, 3-septate, constricted at septum, hyaline, surrounded by thin sheath, smooth-walled. Asexual morph: Undetermined.

Type species - Aphanostigme solani Syd.

Notes - Sydow (1926) introduced the genus Aphanostigme to accommodate a foliicolous fungus, A. solani Syd., as its type and was placed in Dothideaceae. Hansford (1946) placed the genus Aphanostigme in the unitunicate family, Sphaeriaceae (Sphaeriales, Sordariomycetes) based only on ascomata form and ascospore features without considering the asci characters. von Arx \& Müller (1975) separated Aphanostigme from Sphaeriaceae based on its bitunicate asci and placed the genus in Dimeriaceae. Eriksson et al. (2001), Kirk et al. (2008) and Lumbsch \& Huhndorf (2010) listed this genus in Pseudoperisporiaceae, but in an uncertain position. Currently, the genus includes 22 epithets (Index Fungorum 2017). Aphanostigme is characterized by being parasitic on living leaves, having superficial, sphaerical, solitary ascomata, seated on hyphae, with an apical ostiole, oblong to cylindrical, bitunicate asci and cylindrical fusiform, 3-septate, hyaline ascospores, with a thin gelatinous sheath. Aphanostigme shares common characters similar with genera in Phaeosphaeriaceae (Phookamsak et al. 2014). The genus Aphanostigme is therefore placed in the family Phaeosphaeriaceae.

Aphanostigme solani Syd., Annls mycol. 24(5/6): 368 (1926)

Index Fungorum number: IF278342; Facesoffungi number: FoF03691

Fig. 84

Parasitic on surface of living leaves of Solani cfr. lamifolii. Sexual morph: Ascomata 120 $162 \mu \mathrm{m}$ diameter $\times 120.5-154 \mu \mathrm{m}$ high, superficial, globose to subglobose, solitary, seated on dark brown hyphae, covered by dark brown setae, 17-55 $\mu \mathrm{m}$ long $\times 3-4.5 \mu \mathrm{m}$ wide, tapering towards subacute apex, septate, with apical ostiole, 23-33 $\mu \mathrm{m}$ diameter. Peridium 6-9.5 $\mu \mathrm{m}$ wide, comprising 2-3 layers of dark brown cells of textura angularis. Hamathecium $0.5-1 \mu \mathrm{m}$ wide, comprising numerous, branched, septate, hyaline, cylindrical to filiform pseudoparaphyses. Asci 59.5-80 $\times 7-10 \mu \mathrm{m}(\bar{x}=69.5 \times 8.5 \mu \mathrm{m}, \mathrm{n}=10), 8$-spored, bitunicate, fissitunicate, oblong to cylindrical clavate, with minute ocular chamber, pedicellate. Ascospores (14-)15.5-21.5 $\times 4-5 \mu \mathrm{m}$ $(\bar{x}=16 \times 4 \mu \mathrm{m}, \mathrm{n}=15), 2$-seriate, cylindric fusiform, 3-septate, constricted at the septa, hyaline, surrounded by thin sheath, smooth-walled. Asexual morph: Undetermined.

Material examined - COSTA RICA, Alajuela, San Pedro de San Ramon, on surface of living leaves of Solani cfr. lamifolii Mill. (Solanaceae), 2 February 1925, H. Sydow No. 56a (S-F7065, holotype).

Pododimeriaceae Boonmee \& K.D. Hyde, fam. nov.

Index Fungorum number: IF553834; Facesoffungi number: FoF03692

Parasitic on living coniferous leaves. Sexual morph: Ascomata superficial, with or without hypostroma, solitary, scattered, easily removed, black, with apical ostiole. Peridium comprising multi-layers of brown cells of textura angularis. Hamathecium comprising dense, branched, septate, pseudoparaphyses. Asci 8-spored, bitunicate, cylindrical to broadly clavate or ellipsoid, sessile or with knob-like pedicel, apex rounded, with an ocular chamber. Ascospores 2-3-seriate, irregularly arranged, ellipsoid-fusiform to subclavate, rounded at both ends, constricted at the septum, upper cell wider than lower cell, septum supramedian, olivaceous-brown. Asexual morph: Undetermined.

Family type - Pododimeria E. Müll.

Notes - The family Pododimeriaceae is introduced to accommodate two genera Chaetoscutula and Pododimeria which occurs on living leaves of conifers. The family is characterized by being parasitic on coniferous plants with superficial, dark pigmented ascomata, saccate bitunicate asci and 1-septate, pigmented ascospores. As there are no families suited to accommodate these genera, a new family is introduced here. 

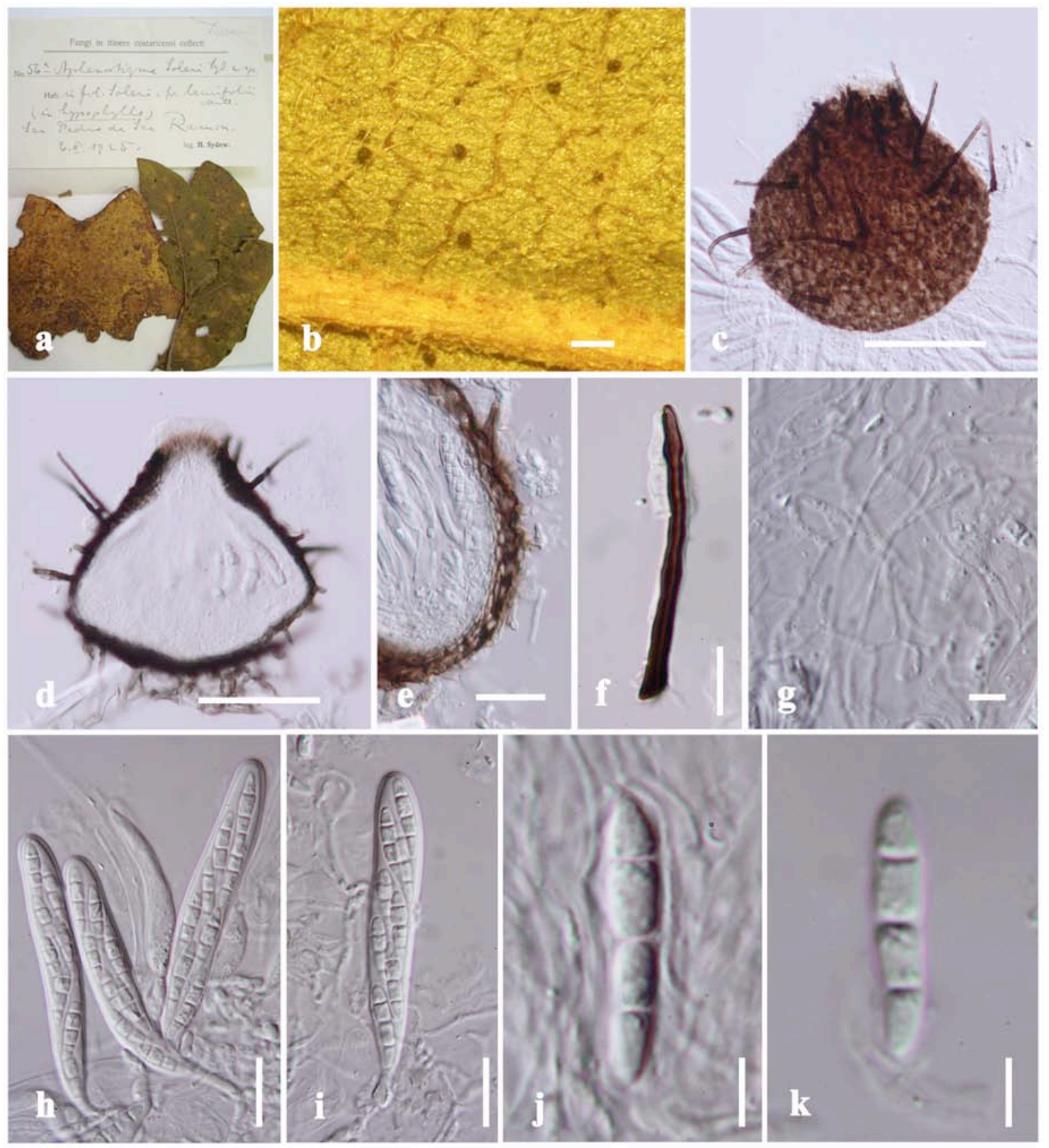

Figure 84 - Aphanostigme solani (S-F7065, holotype). a Herbarium specimen and habit on leaves. b Appearance of ascomata on leaf surface. $c$, d Squash mount and section of ascomata. e Peridium. f Seta. g Pseudoparaphyses. $\mathrm{h}-\mathrm{j}$ Asci. j, k Ascospores. Scale bars: $\mathrm{b}=200 \mu \mathrm{m}, \mathrm{c}, \mathrm{d}=50 \mu \mathrm{m}, \mathrm{e}, \mathrm{h}-\mathrm{j}$ $=20 \mu \mathrm{m}, \mathrm{f}=10 \mu \mathrm{m}, \mathrm{g}, \mathrm{k}=5 \mu \mathrm{m}$.

Pododimeria E. Müll., Sydowia 12(1-6): 193 (1959) [1958]

Parasitic on living coniferous leaves. Sexual morph: Ascomata superficial, globose to subglobose, forming a basal hypostromatic stalk, with dark hyphal stands, solitary, scattered, easily removed, black, with apical ostiole. Peridium comprising multi-layers of brown cells of textura angularis. Hamathecium comprising dense, branched, septate, hyaline pseudoparaphyses, constricted at the septa. Asci 8-spored, bitunicate, cylindrical to broadly clavate or ellipsoid, sessile or with knob-like pedicel, apex rounded with an ocular chamber. Ascospores 2-3-seriate, irregularly arranged, ellipsoid-fusiform to subclavate, rounded at both ends, 1-septate, constricted at the septum, upper cell wider than lower cell, septum supramedian, olivaceous brown, with minutely verruculose walls. Asexual morph: Undetermined.

Type species - Pododimeria gallica E. Müll. 
Notes - Pododimeria was introduced by Müller (1958) for the single species P. gallica. Pododimeria has been included in the families Capnodiaceae, Dimeriaceae and Parodiellaceae based on its epiphytic habit and the features of ascomata and ascospores (Gäumann 1964, von Arx and Müller 1975, Barr 1987, Jaklitsch et al. 2002). The genus is characterized by sphaerical, superficial, stalked ascomata, with apical ostiole, cylindrical to broadly clavate, bitunicate asci and 1-septate, olivaceous brown, verruculose ascospores. Hawksworth et al. (1995) included Pododimeria in Pseudoperisporiaceae, as did Kirk et al. (2008), Lumbsch \& Huhndorf (2010), Hyde et al (2013) and Wijayawardene et al. (2014). The genus comprises four species, $P$. andina Butin, P. gallica E. Müll., P. gelatinosa Luttr. \& M.E. Barr and P. juniperi (Bat. \& Peres) Luttr. \& M.E. Barr and all species are found on living leaves of coniferous plants (Müller 1958, Butin 1973, Luttrell \& Barr 1978). Pododimeria differs from the species in Pseudoperisporiaceae in the features of ascomata and ascospores. Thus, a new family Pododimeriaceae is introduced to accommodate two genera found on conifers.

Pododimeria gallica E. Müll., Sydowia 12(1-6): 195 (1959) [1958]

Index Fungorum number: IF304077; Facesoffungi number: FoF03693

Fig. 85

Parasitic on living, scale-like leaves of Juniperus phoenicea L. Sexual morph: Ascomata 133-143 $\mu \mathrm{m}$ diameter $\times 129.5-157.5 \mu \mathrm{m}$ high, superficial, globose to subglobose, forming a basal hypostromatic stalk, with dark hyphal strands, solitary, scattered, easily removed, black, with apical ostiole. Peridium 13-21 $\mu \mathrm{m}$ wide, comprising multi-layers of brown cells of textura angularis. Hamathecium comprising ca. $3 \mu \mathrm{m}$ wide, dense, branched, septate, hyaline pseudoparaphyses, constricted at the septa. Asci 63-98 $\times 19-30 \mu \mathrm{m}(\bar{x}=79 \times 23 \mu \mathrm{m}, \mathrm{n}=15), 8$-spored, bitunicate, cylindrical to broadly clavate or ellipsoid, sessile or with knob-like pedicel, apex rounded with an ocular chamber. Ascospores 21-26.5 $\times 8.5-10 \mu \mathrm{m}(\bar{x}=24 \times 9 \mu \mathrm{m}, \mathrm{n}=20), 2-3$-seriate, irregularly arranged, ellipsoid-fusiform to subclavate, rounded at both ends, 1-septate, constricted at the septum, upper cell wider than lower cell, septum supramedian, olivaceous brown, minutely verruculose. Asexual morph: Undetermined.

Material examined - FRANCE, Province Gorges du Verdon, above the bridge over the Artuby River, on living leaves of Juniperus phoenicea L. (Cupressaceae), 24 June 1956, E. Müller 22813/11 (Z 33992, holotype).

Chaetoscutula E. Müll., Sydowia 12(1-6): 190 (1959) [1958]

Parasitic or saprobic on living and dead leaves. Sexual morph: Ascomata solitary, scattered, superficial on the leaves and easily removed, globose to subglobose, black, sometimes with long and brown setae, with inconspicuous ostiole. Peridium comprising 2-3 layers of brown cells of textura angularis. Hamathecium comprising cylindrical, branched or simple, septate, cellular, hypha-like pseudoparaphyses, encircling the asci and embedded in a gelatinous matrix. Asci 8spored, bitunicate, cylindrical to broadly clavate or ellipsoid, with short pedicel, without a conspicuous ocular chamber. Ascospores 2-seriate, ellipsoid to fusiform, 1-septate, with dark septum, ends rounded, upper cell wider, lower cell narrow and longer, hyaline, becoming brown at senescence, minutely verruculose. Asexual morph: Undetermined.

Type species - Chaetoscutula juniperi E. Müll.

Notes - Tian et al. (2014) re-examined the specimen of Chaetoscutula, C. juniperi from S (F 225899) and included the genus in the family Pseudoperisporiaceae. Chaetoscutula juniperi shares similar characters of asci and ascospores and is also on the same host substrate with Pododimeria. Müller (1958) placed Chaetoscutula as a separate genus with Pododimeria based on ascomatal features in having a basal subiculum, hemisphaerical, with long brown setae and thickened wall, while Pododimeria forms basally hypostromatic stalked ascomata (see Illustrations 1-3 in Müller 1958). We include Chaetoscutula in Pododimeriaceae based on the hosts and the features of asci and ascospores. Molecular data may show these genera to synonymous. 

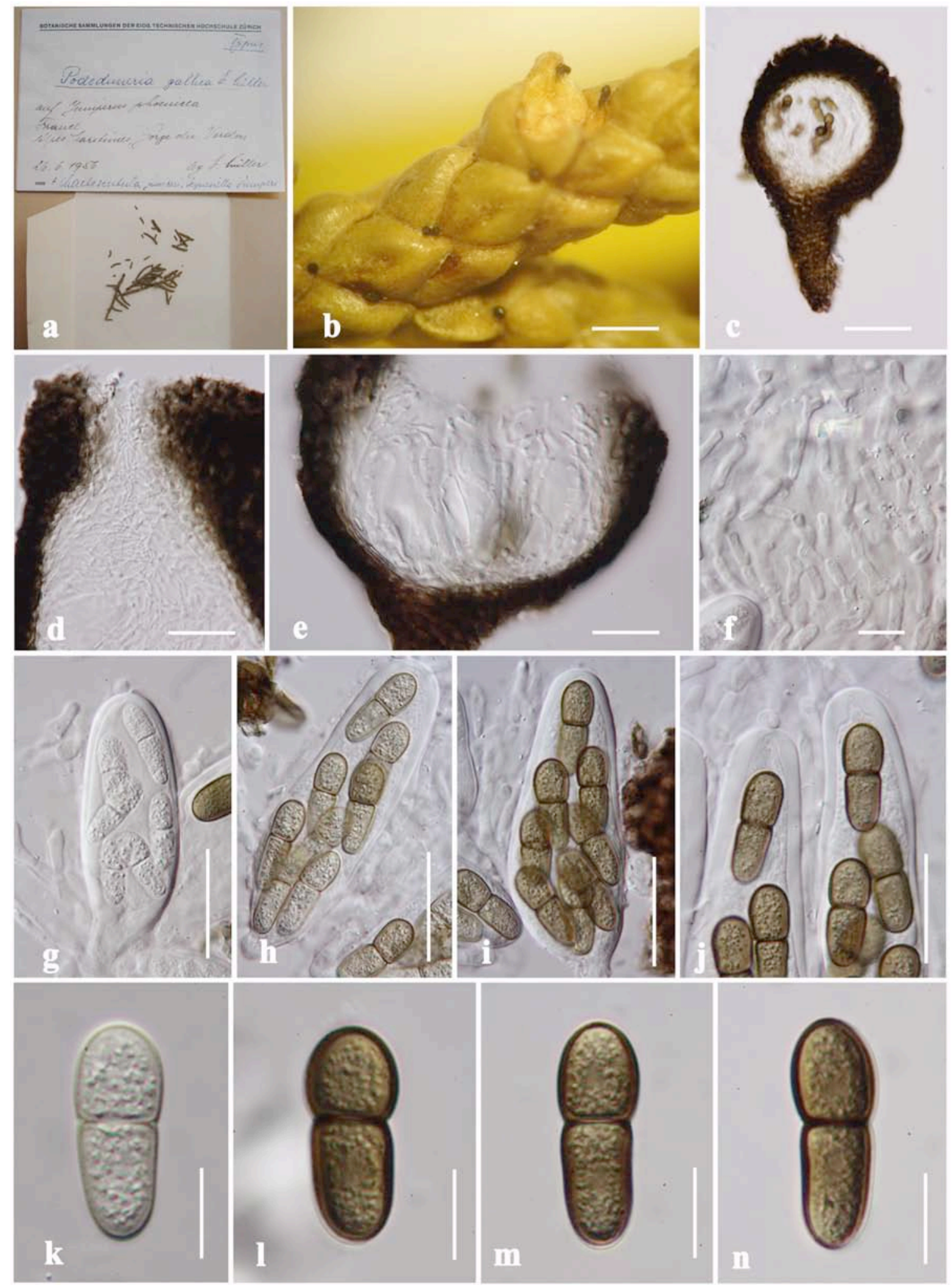

Figure 85 - Pododimeria gallica (Z 22813/11, holotype). a Herbarium specimen and habit on coniferous leaves. b Appearance of ascomata on leaf surface. c Section of ascoma. d Close up of apical ostiole. e Peridium. f Pseudoparaphyses. $\mathrm{g}-\mathrm{i}$ Asci. $\mathrm{j}$ Close up of ocular chamber in asci. $\mathrm{k}-\mathrm{n}$ Ascospores. Scale bars: $\mathrm{b}=500 \mu \mathrm{m}, \mathrm{c}=100 \mu \mathrm{m}, \mathrm{d}, \mathrm{e}, \mathrm{g}-\mathrm{j}=40 \mu \mathrm{m}, \mathrm{f}=5 \mu \mathrm{m}, \mathrm{k}-\mathrm{n}=10 \mu \mathrm{m}$.

Chaetoscutula juniperi E. Müll., Sydowia 12(1-6): 191 (1959) [1958] Index Fungorum number: IF294737; Facesoffungi number: FoF03694 Notes - For a detailed morphological description see in Tian et al. (2014). 

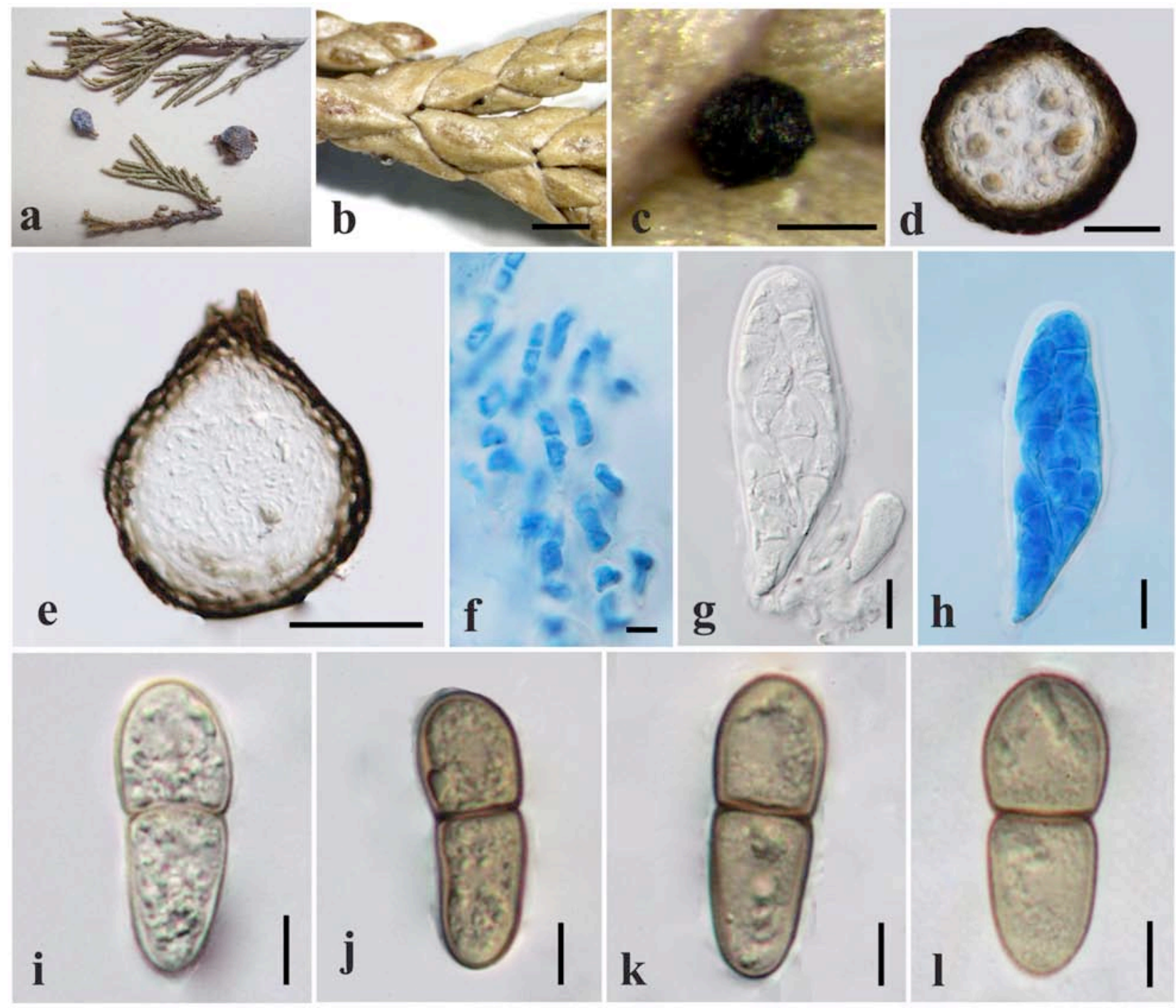

Figure 86 - Chaetoscutula juniperi (Modified from Fig. 1 in Tian et al. 2014). a Herbarium specimen and habit on coniferous leaves. b, c Appearance of ascomata on leaf surface. d, e Section of ascoma and peridium. f Pseudoparaphyses. g, h Asci. i-1 Ascospores. Scale bars: $b=1000 \mu \mathrm{m}, \mathrm{c}$ $=100 \mu \mathrm{m}, \mathrm{d}, \mathrm{e}=50 \mu \mathrm{m}, \mathrm{f}, \mathrm{i}-1=5 \mu \mathrm{m}, \mathrm{g}, \mathrm{h}=10 \mu \mathrm{m}$.

Polyclypeolinaceae Boonmee \& K.D. Hyde, fam. nov.

Index Fungorum number: IF553835; Facesoffungi number: FoF03695

Saprobic, epiphyllous on dried leaves. Sexual morph: Ascomata epiphyllous, superficial, thyriothecial, irregular, scattered to loosely clustered, dark brown to black, slightly shield-like or shallow-convex, composed of epithecium membranaceous cells, edge entire, with apical ostiole. Peridium comprising multi-layers of dark brown cells of textura angularis. Hamathecium comprising branched, septate, pseudoparaphyses. Asci 8-spored, bitunicate, fissitunicate, saccate, cylindric-clavate, pedicellate. Ascospores ellipsoid to fusiform, narrowly obovoid, 1-septate, upper cell wider, tapering towards narrow end, hyaline. Asexual morph: Undetermined.

Family type - Polyclypeolina Bat. \& I.H. Lima

Notes - Polyclypeolinaceae is introduced to accommodate the genus Polyclypeolina based on its ascomata characteristics to separate it from Aulographaceae. Polyclypeolinaceae is characterized by epiphyllous, superficial, irregular thyriothecial ascomata, cylindric-clavate, fissitunicate asci and ellipsoid to fusiform, 1-septate and hyaline ascospores. Polyclypeolinaceae is based on the type species $P$. brideliae and differs from Aulographaceae by its branched colonies, irregular thyriothecial ascomata and the features of asci and ascospores. 


\section{Polyclypeolina Bat. \& I.H. Lima}

Saprobic, epiphyllous on dried leaves. Sexual morph: Ascomata epiphyllous, superficial, thyriothecial, irregular, scattered to loosely clustered, dark brown to black, slightly shield-like or shallow-convex, composed of epithecium membranaceous cells, edge entire, with apical ostiole. Peridium comprising multi-layers of dark brown cells of textura angularis. Hamathecium comprising branched, septate, hyaline, pseudoparaphyses. Asci 8-spored, bitunicate, fissitunicate, saccate, cylindric-clavate, pedicellate. Ascospores ellipsoid to fusiform, narrowly obovoid, 1septate, constricted at the septum, upper cell wider, tapering towards narrow end, hyaline, smoothwalled. Asexual morph: Undetermined.

Type species - Polyclypeolina brideliae (Hansf.) Bat.

Notes - Polyclypeolina was introduced by Batista (1959) to accommodate the monotypic species $P$. brideliae and is poorly studied. The genus is based on the earlier name Polyclypeolum brideliae Hansf. (Hansford 1945). The genus is characterised by superficial, epiphyllous, dark pigmented thyriothecia, lacking penetrating hyphae. Luttrell (1973) included the genus in the family Aulographaceae based on branched colonies, superficial, irregular, multi-loculate ascomata, with opening slit on the top and 1-septate, hyaline ascospores. Based on the thyriothecium and ascospore features, we introduce the family Polyclypeolinaceae.

Polyclypeolina brideliae (Hansf.) Bat., Publções Inst. Micol. Recife 56: 457 (1959)

三 Polyclypeolum brideliae Hansf., Publções Inst. Micol. Recife 56: 458 (1945) [1944-45]

Index Fungorum number: 304116; Facesoffungi number: FoF03696

Fig. 87

Saprobic, epiphyllous on dried leaves of Brideliae micranthae (Hochst.) Baill. Ascomata 57.5-73(-83) $\mu \mathrm{m}$ high $\times 225-259.5 \mu \mathrm{m}$ diameter, epiphyllous, thyriothecial, superficial, irregular, scattered to loosely clustered, dark brown to black, slightly shield-like or shallow-convex, composed of epithecium membranaceous cells, edge entire, with apical ostiole, 21-26 $\mu \mathrm{m}$ diameter. Peridium 21-27 $\mu \mathrm{m}$ wide, comprising multi-layers of dark brown cells of textura angularis. Hamathecium comprising branched, septate, hyaline, pseudoparaphyses. Asci 47.5-64 × 11-13 $\mu \mathrm{m}$ $(\bar{x}=54 \times 12 \mu \mathrm{m}, \mathrm{n}=15), 8$-spored, bitunicate, fissitunicate, saccate, cylindric-clavate, with long pedicel. Ascospores $11.5-15 \times 3-4 \mu \mathrm{m}(\bar{x}=13 \times 3 \mu \mathrm{m}, \mathrm{n}=15)$, narrowly obovoid, subclavate, with 4-6(-14) $\mu \mathrm{m}$ long pedicel, 1-septate, constricted at the septum, upper cell wider, tapering towards narrow end, hyaline, without guttules.

Material examined - UGANDA, Entebbe, on dried leaves of Brideliae micranthae (Hochst.) Baill. (Euphorbiaceae), 1945, G.C. Hansford 3309 (K (M) 177972, holotype).

\section{Pseudoperisporiaceae Toro}

Hyde et al. (2013) revised the family Pseudoperisporiaceae and its type genus Lasiostemma Theiss., Syd. \& P. Syd. based on type species Lasiostemma melioloides. All genera in Pseudoperisporiaceae are parasitic or saprobic associated with leaf substrates that have relatively large colonies, superficial, sphaerical, uniloculate, pigmented ascomata, surrounded by hyphae, with an apical pore, with or without setae, bitunicate asci and hyaline to coloured, septate ascospores (Hyde et al. 2013). We presently accept three genera Eudimeriolum, Lasiostemma and Nematostoma in Pseudoperisporiaceae.

Eudimeriolum Speg., Anal. Mus. nac. Hist. nat. B. Aires 23: 36 (1912)

Saprobic on dead leaves. Sexual morph: Ascomata superficial, solitary, irregularly, dehiscent, globose to subglobose, membranaceous, with coarse context, parenchymatous, olivaceous. Asci 8spored, bitunicate, cylindrical to clavate, narrow towards the base, short pedicellate, apex rounded, with filiform pseudoparaphyses. Ascospores 1-2-seriate, fusoid to subclavate, upper cell wider, basal cell with acute base, 1-septate, hyaline when immature, becoming pale green when mature. Asexual morph: Undetermined.

Type species - Eudimeriolum elegans Speg. 


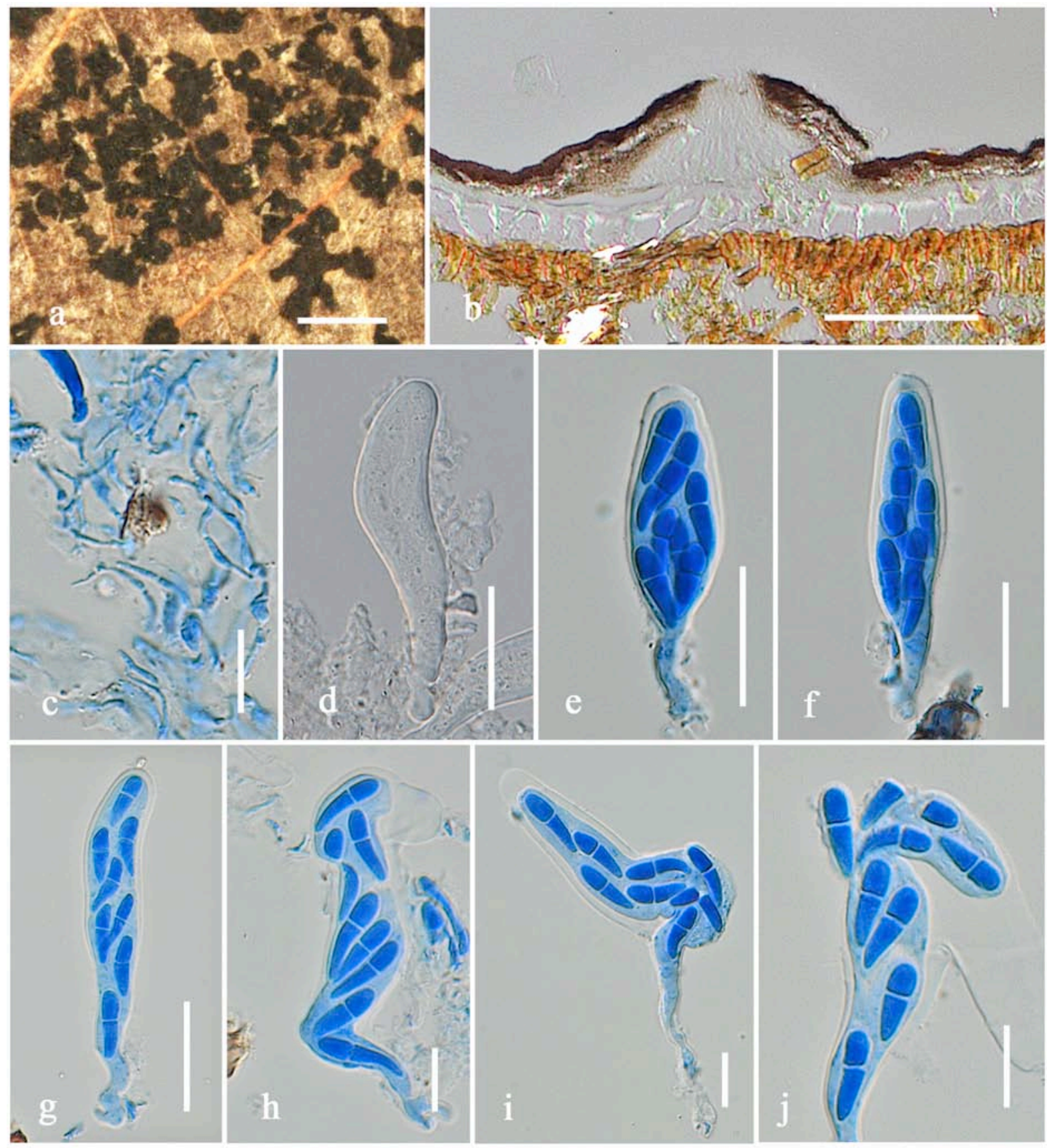

Figure 87 - Polyclypeolina brideliae (K (M) 177972, holotype). a Herbarium specimen and habit on leaf. b Section of ascoma. c Pseudoparaphyses. $d-g$ Immature and mature asci. $h-j$ Ascospores released from asci. Scale bars: $\mathrm{a}=2 \mathrm{~mm}, \mathrm{~b}=100 \mu \mathrm{m}, \mathrm{c}, \mathrm{h}-\mathrm{j}=10 \mu \mathrm{m}, \mathrm{d}-\mathrm{g}=20 \mu \mathrm{m}$.

Notes - Eudimeriolum was introduced by Spegazzini (1912) as a monotypic genus with $E$. elegans as the type. The genus is characterized by superficial ascomata, sphaerical, membranaceous, olivaceous, 8-spored asci and 1-septate and hyaline ascospores. Hansford (1946) placed Eudimeriolum in Sphaeriaceae based on the glabrous ascomata without appendaged mycelia. von Arx and Müller (1975) transferred it to Dimeriaceae based on saprobic characters, mainly growing on leaves, superficial mycelium and glabrous ascomata. Barr (1997) reviewed several dimeriaceous taxa and accepted Eudimeriolum in the family Pseudoperisporiaceae. Currently, the genus comprises 20 species epithets (Index Fungorum 2017). We provide a brief description of Eudimeriolum elegans to represent the genus based on the protologue of Spegazzini (1912). All species share common features with other genera in Pseudoperisporiaceae such as superficial, sphaerical, uniloculate ascomata, with or without superficial mycelia, bitunicate asci, 
septate and hyaline to pigmented ascospores. Hence, we maintain this genus in Pseudoperisporiaceae (Barr 1997, Eriksson 1999, Reynolds \& Gilbert 2005, Kirk et al. 2008, Lumbsch \& Huhndorf 2010, Hyde et al. 2013, Wijayawardene et al. 2014, 2017).

Eudimeriolum elegans Speg., Anal. Mus. nac. Hist. nat. B. Aires 23: 36 (1912)

Index Fungorum number: IF249821; Facesoffungi number: FoF03697

Fig. 88

Saprobic on dead leaves of Lueheae divaricatae (Tiliaceae). Sexual morph: Ascomata 120 $180 \mu \mathrm{m}$ diameter, superficial, solitary, irregular, dehiscent, globose to subglobose, membranaceous, with coarse context, parenchymatous, olivaceous. Asci $60-70 \times 8-10 \mu \mathrm{m}, 8$-spored, bitunicate, cylindrical to clavate, narrow towards the base, short pedicellate, apex rounded, with filiform paraphyses. Ascospores 14-15 × 4-5 $\mu \mathrm{m}, 1-2$-seriate, fusoid to subclavate, upper cell wider, basal cell narrower with acute base, 1-septate, not constricted at the septum, hyaline when immature, becoming pale green when mature (from Spegazzini 1912). Asexual morph: Undetermined.
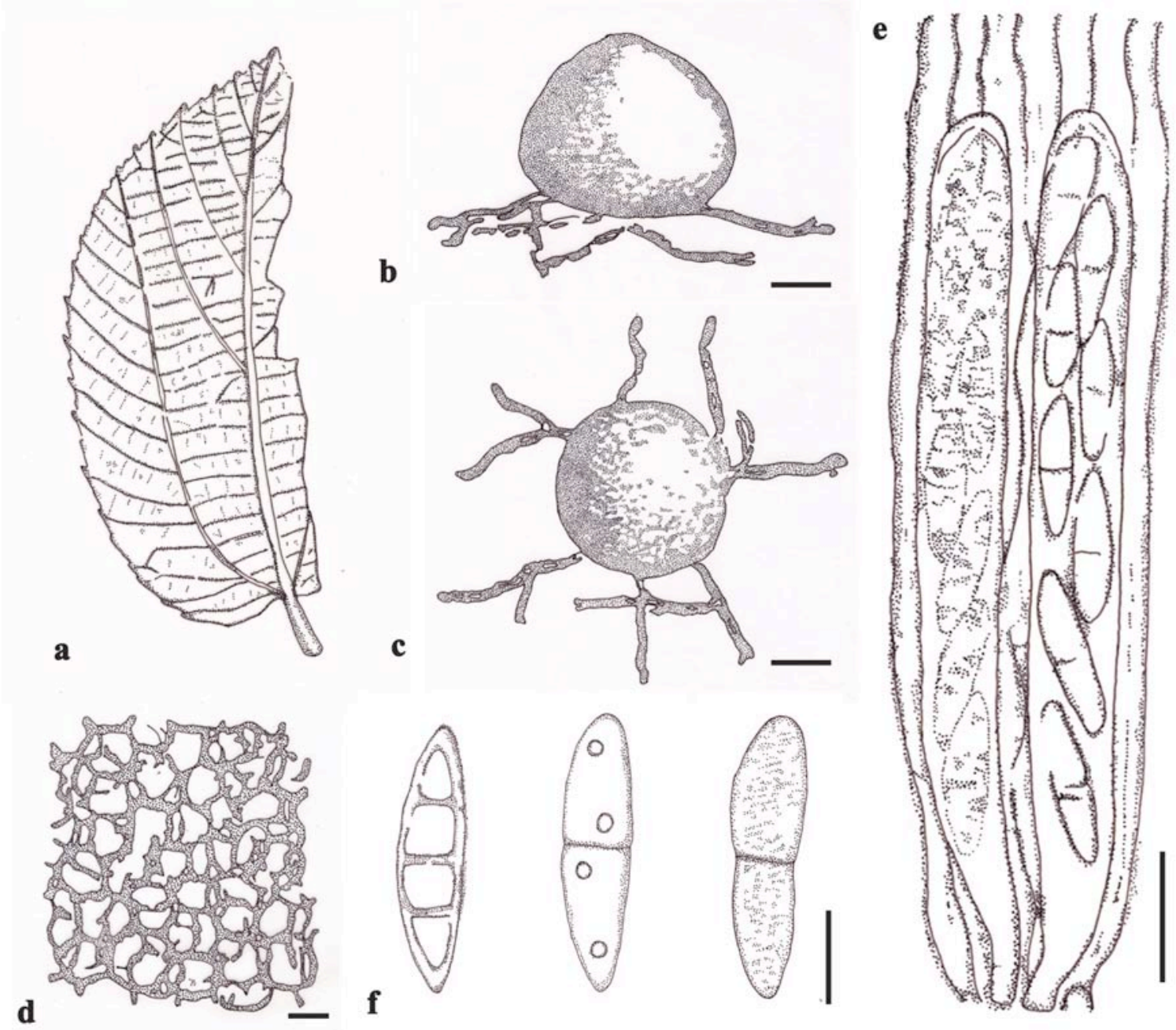

Figure 88 - Eudimeriolum elegans (redrawn from Spegazzini 1912, Fig. 82). a Leaf substrate with ascomata. b, c Ascomata. d Hyphal colony. e Asci. f Ascospores. Scale bars: b, c $=50 \mu \mathrm{m}, \mathrm{d}, \mathrm{f}=5$ $\mu \mathrm{m}, \mathrm{e}=5 \mu \mathrm{m}$.

Lasiostemma Theiss., Syd. \& P. Syd., Annls mycol. 15(3/4): 218 (1917)

Parasitic on leaves of Erigeron bonariensis in tropical regions. Sexual morph: Ascomata superficial, solitary to gregarious, scattered, globose to subglobose, with brown mycelium at the base, with apical ostiole, collapsing when dry, surrounded by brown setae, septate, tapering to subacute apex. Peridium comprising reddish-brown cells of textura angularis to subglobosa. 
Hamathecium comprising branched, septate, hyaline pseudoparaphyses. Asci 8-spored, bitunicate, fissitunicate, oblong-clavate, sessile or with knob-like pedicel, slightly curved, apically thickened, with small ocular chamber. Ascospores 2-seriate in the ascus, fusoid-ellipsoid, rounded and subacute ends, 1-septate, septum submedian, slightly constricted at the septum, hyaline, becoming brownish at maturity, minutely verrucose. Asexual morph: coelomycetous, known as Chaetosticta (Kirk et al. 2008).

Type species - Lasiostemma melioloides (Berk. \& Ravenel) Theiss. et al.

Notes - Hyde et al. (2013) examined, illustrated and described a specimen of Lasiostemma melioloides (BPI699548) to represent the family Pseudoperisporiaceae. The genus is characterized by superficial, red brown to dark pigmented ascomata, with long hyphae, oblong-clavate asci and fusoid-ellipsoid, 1-septate, light brown ascospores. Currently, eight species epithets are listed in the genus Lasiostemma (Index Fungorum 2017).

Lasiostemma melioloides (Berk. \& Ravenel) Theiss., Syd. \& P. Syd., Annls mycol. 15(3/4): 218 (1917)

三Dimeriella melioloides Berk. \& Ravenel

Index Fungorum number: IF102249; Facesoffungi number: FoF03698

Fig. 89

Parasitic on leaves of Erigeron bonariensis in tropical regions. Sexual morph: Ascomata (94-)102.5-116 $\mu \mathrm{m}$ diameter, superficial, solitary to gregarious, scattered, globose to subglobose, with brown mycelium at the base, with apical 14-18(-20) $\mu \mathrm{m}$ diameter ostiole, collapsing when dry, surrounded by brown setae, 71-111(-140) $\mu \mathrm{m}$ long, septate, tapering to subacute apex. Peridium comprising reddish-brown cells of textura angularis to subglobosa. Hamathecium comprising ca. $2 \mu \mathrm{m}$ wide, branched, septate, hyaline pseudoparaphyses. Asci 36-40 $3-10 \mu \mathrm{m}(\bar{x}$ $=39 \times 9 \mu \mathrm{m}, \mathrm{n}=10), 8$-spored, bitunicate, fissitunicate, oblong-clavate, sessile or with knob-like pedicel, slightly curved, apically thickened, with small ocular chamber. Ascospores 11-13 $\times 3-4$ $\mu \mathrm{m}(\bar{x}=12 \times 4 \mu \mathrm{m}, \mathrm{n}=10), 2$-seriate in the ascus, fusoid-ellipsoid, with rounded to subacute ends, 1 -septate, septum submedian, slightly constricted at the septum, hyaline, becoming brownish at maturity, minutely verrucose. Asexual morph: coelomycetous, known as Chaetosticta.

Nematostoma Syd. \& P. Syd., Annls mycol. 12(2): 161 (1914)

Parasitic on living leaves. Sexual morph: Ascomata superficial, globose to subglobose, dark brown, with apical ostiole, surrounded by long, septate, dark brown setae, tapering to acute at the apex. Peridium comprising 2-3 layers of dark brown cells of textura angularis. Hamathecium comprising numerous cylindrical, filiform, branched, septate, anastomosed, hyaline, pseudoparaphyses. Asci 8-spored, bitunicate, cylindric-clavate, sessile or with short pedicel, apically thickened and rounded. Ascospores 2-seriate, ellipsoid to fusiform, upper part wider, slightly curved, multi-septate, constricted at the septa, hyaline to light brown, smooth-walled. Asexual morph: Undetermined.

Type species - Nematostoma artemisiae Syd. \& P. Syd.

Notes - Nematostoma was described and introduced in Sphaeriaceae by Sydow \& Sydow (1914) to accommodate the parasitic type $N$. artemisiae. Nematostoma artemisiae shares similar morphological features with Acanthostigmella Höhn., but it differs in lifestyle as a plant parasite. Nematostoma comprises 20 epithets (Hansford 1946, Petrak 1949, 1950, 1952, 1955, Batista et al. 1967, Rossman 1987, Sivanesan 1987, Barr 1968, 1997, Pande 2008). von Arx \& Müller (1975) included Nematostoma in Dimeriaceae as it is parasitic on leaves. Barr (1997) revised and accepted Nematostoma in Pseudoperisporiaceae and subsequent studies by Kirk et al. (2008) and Hyde et al. (2013) followed this placement. The type species $N$. artemisiae is characterized by being parasitic on leaf hairs, with a subiculum bearing ascomata, ostioles surrounded by long setae, bitunicate asci and 3-septate, light brown ascospores. Therefore, we maintain the genus Nematostoma in Pseudoperisporiaceae. 


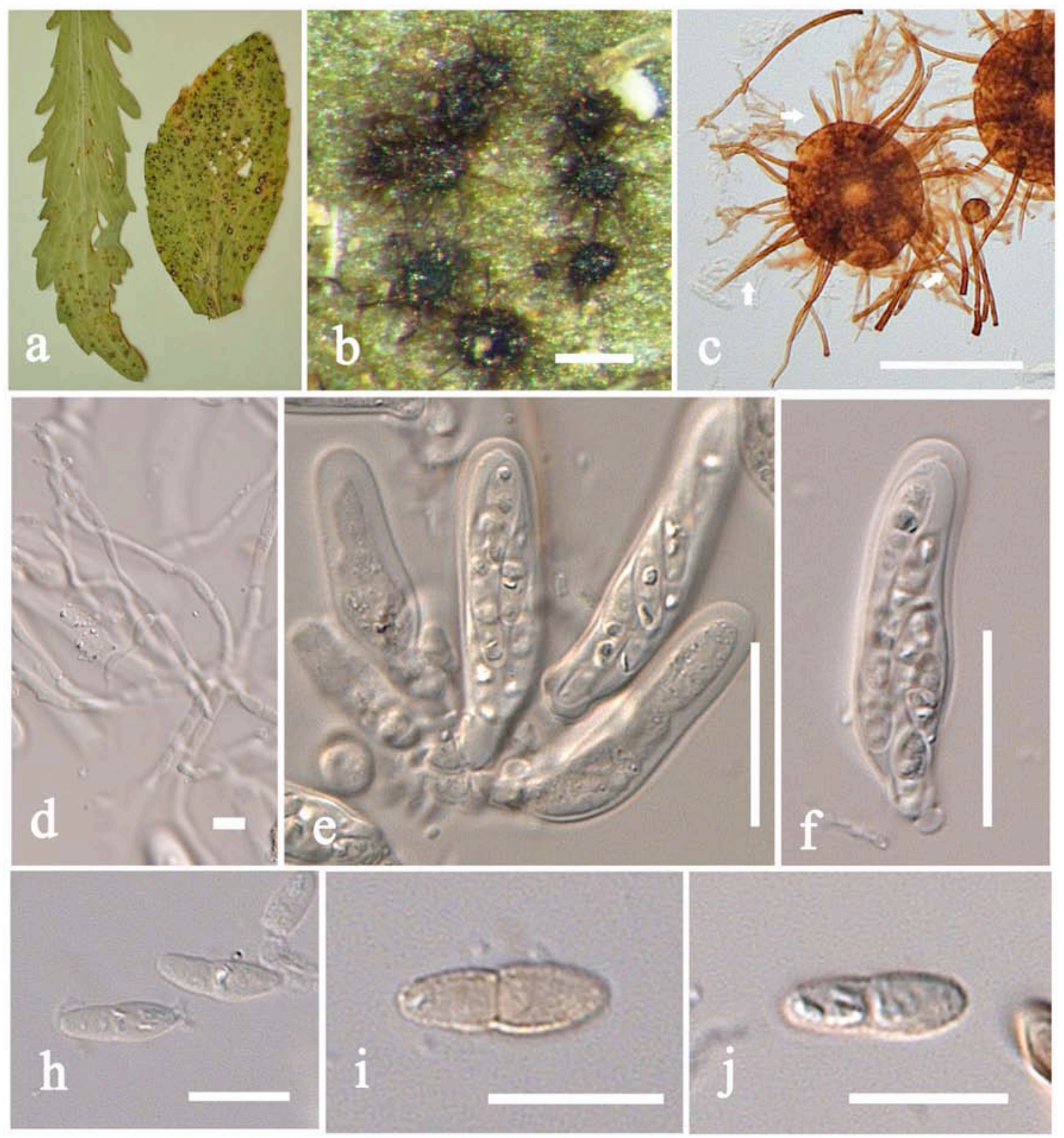

Figure 89 - Lasiostemma melioloides (modified from Fig. 108 in Hyde et al. 2013). a Herbarium specimen and habit on leaves. b Appearance of ascomata on leaf surface. c Squash mount of ascoma. $d$ Pseudoparaphyses. e, f Asci. $h-j$ Ascospores. Scale bars: $b, c=100 \mu \mathrm{m}, \mathrm{d}=5 \mu \mathrm{m}, \mathrm{e}, \mathrm{f}=$ $20 \mu \mathrm{m}, \mathrm{h}-\mathrm{j}=10 \mu \mathrm{m}$.

Nematostoma artemisiae Syd. \& P. Syd., Annls mycol. 12(2): 161 (1914)

Index Fungorum number: IF249201; Facesoffungi number: FoF03699

Fig. 90

Parasitic on leaf hairs on lower surface of living leaves of Artemisia vulgaris var. indica. Sexual morph: Ascomata 140-160 $\mu \mathrm{m}$ diameter, superficial, globose to slightly subglobose, dark brown, or with poorly developed subiculum, with apical ostiole, surrounded by long setae, 150-250 $\mu \mathrm{m}$ long $\times 3-5 \mu \mathrm{m}$ wide, slightly curved, tapering to acute at the apex, septate, dark brown. Peridium 6.5-9 $\mu \mathrm{m}$ wide, comprising 2-3 layers of dark brown cells of textura angularis. Hamathecium 1-2 $\mu \mathrm{m}$ wide, comprising numerous, cylindrical, filiform, branched, septate, anastomosed, hyaline, pseudoparaphyses. Asci 50-65 × 7-9.5 $\mu \mathrm{m}(\bar{x}=56.5 \times 8 \mu \mathrm{m}, \mathrm{n}=20)$, 8-spored, bitunicate, cylindric-clavate, sessile or with short pedicel, apically thickened and rounded. Ascospores 14-17 $\times$ 3-5 $\mu \mathrm{m}(\bar{x}=15 \times 4 \mu \mathrm{m}, \mathrm{n}=20), 2$-seriate, ellipsoid to fusiform, upper part wider, slightly curved, regular 3-septate, constricted at the septa, hyaline to light brown, smooth-walled. Asexual morph: Undetermined. 
Material examined - JAPAN, Hokkaido, Maruyama, on living leaves of on Artemisia vulgaris var. indica. (Willd.) Hassk. (Asteraceae), 24 September 1907, M. Miura No. 550 (SF10261, holotype).

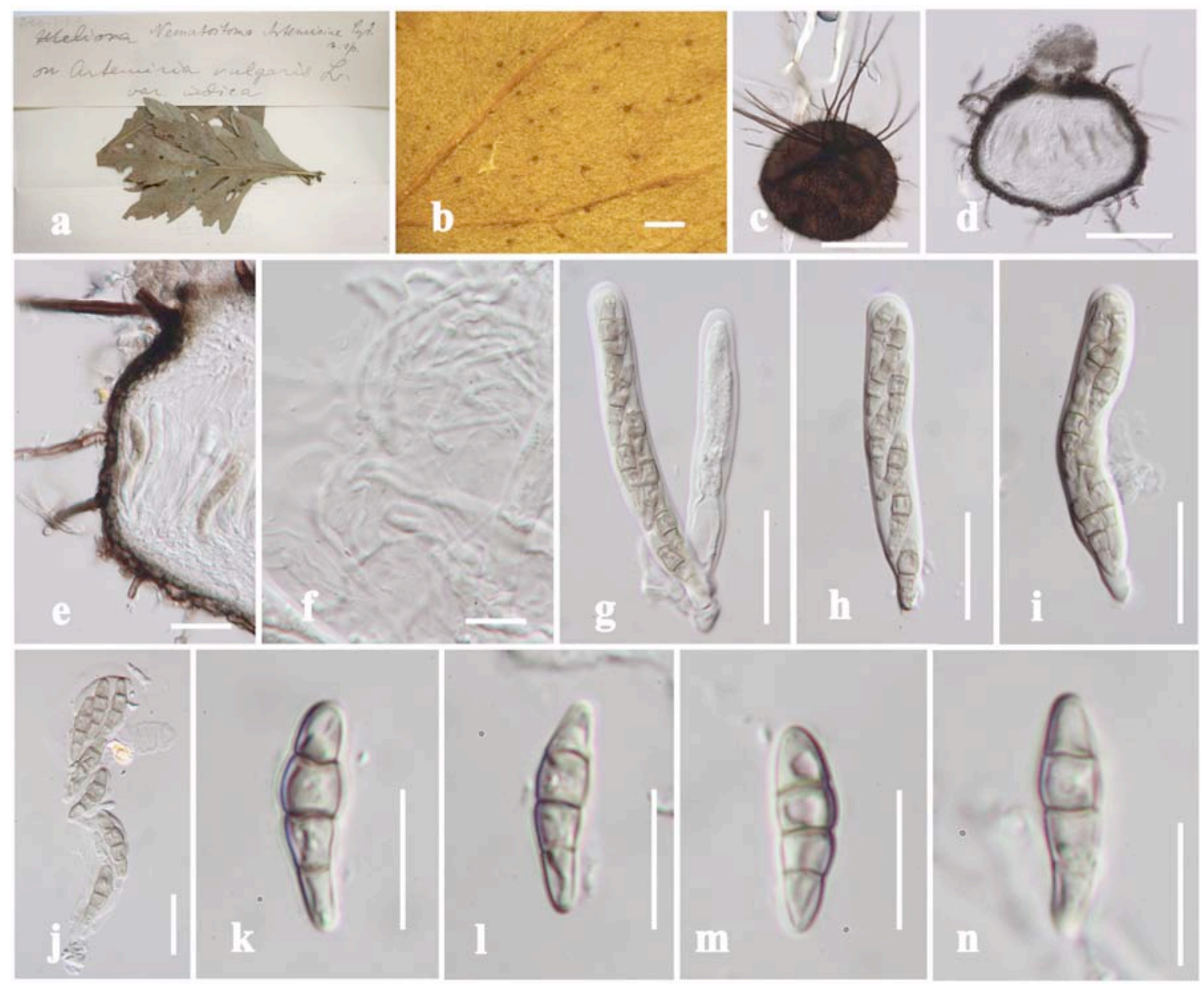

Figure 90 - Nematostoma artemisiae (S-F10261, holotype). a Herbarium specimen and habit on leaves. b Appearance of ascomata on leaf surface. c, d Squash mount oozing mass of ascospores and section of ascomata with long apical setae and ostiole. e Peridium. f Pseudoparaphyses. g-i Asci. $\mathrm{j}-\mathrm{n}$ Ascospores. Scale bars: $\mathrm{b}=500 \mu \mathrm{m}, \mathrm{c}, \mathrm{d}=100 \mu \mathrm{m}, \mathrm{e}, \mathrm{g}-\mathrm{i}=20 \mu \mathrm{m}, \mathrm{f}, \mathrm{j}-\mathrm{n}=10 \mu \mathrm{m}$.

Schizothyriaceae Höhn. ex Trotter, Sacc., D. Sacc. \& Traverso [as 'Schizothyrieae']

Schizothyriaceae was introduced by Saccardo (1928) as "Schizothyrieae" based on von Höhnel (1917). The family was introduced to accommodate epiphytic fungi which were originally described as "exciple depressed on cuticle, superficial, membranous, irregular fringed when mature" (Saccardo 1928, Phookamsak et al. 2016). The family is poorly studied and contained various ambiguous genera, mostly confused with the genera in Micropeltidaceae (Müller \& von Arx 1962, von Arx \& Müller 1975, Phookamsak et al. 2016). Phookamsak et al. (2016) recircumscribed the genera in Schizothyriaceae based on morphological study of generic types and accepted only five genera in this family viz. Hexagonella, Lecideopsella, Mycerema, Plochmopeltis and Schizothyrium. Schizothyriaceae has unique characters of membranous, multi-loculate ascostromata, with each ascus forming in a locule, which is a "cell" in a network-like structure and in lacking ostioles (Phookamsak et al. 2016).

Schizothyrium Desm., Annls Sci. Nat., Bot., sér. 3 11: 360 (1849)

Pathogenic on leaves, stems, or other parts of various dicotyledonous vascular plants such as Acer and Quercus. Sexual morph: Ascomata scattered, solitary to gregarious, superficial, flattened, 
circular to ellipsoid, light brown or dark brown to black, sphaerical or orbicular, glabrous, uniloculate, membranous, opening by splitting of the upper wall. Peridium thin-walled, poorlydeveloped at the base, comprising irregular meandering arrangement of dark brown, compact cells, membranous, in vertical section arranged in textura angularis to globulosa. Hamathecium comprising broad, septate, network-like structure. Asci 8-spored, bitunicate, globose to subglobose, or ovoid, sessile, apex rounded, with an indistinct ocular chamber. Ascospores irregularly seriate, hyaline, oblong to clavate, 1-septate, slightly constricted at the septum, thick, rough-walled, with small guttules. Asexual morph: hyphomycetous, see notes below.

Type species - Schizothyrium acerinum Desm.

Notes - Schizothyrium was introduced by Desmazières (1849) and is typified by S. acerinum which was collected from Acer negundo. Schizothyrium has been reported on leaves, stems, or other parts of various vascular plants such as Acer, Artocarpus, Bambusa, Crataegus, Gaultheria, Ilex, Malus, Phyllostachys, Pinus and Quercus and is widespread in temperate and tropical regions (Eriksson 1981, Phookamsak et al. 2016, Farr \& Rossman 2017). These reports however need confirmation with molecular data. Sixty-nine epithets of Schizothyrium are listed in Index Fungorum (2017). Most species of the genus lack molecular data to confirm their phylogenetic affinities and the generic type has not yet been recollected and its phylogenetic position clarified (Hyde et al. 2013, Phookamsak et al. 2016). Molecular data is only available for S. pomi and its asexual morph (Batzer et al. 2005, 2008, Crous et al. 2009, Ma et al. 2010, Phookamsak et al. 2016).

Schizothyrium pomi was introduced by von Arx (1959) based on a combination of Labrella pomi Mont. \& Fr. and synonymized under Microthyriella rubi Petrak (Williamson \& Sutton 2000). The species is well-known as a pathogen causing sooty blotch and flyspeck disease on apple and various angiosperms (Williamson \& Sutton 2000, Batzer et al. 2005, 2008, Farr \& Rossman 2017). Schizothyrium pomi is similar to $S$. acerinum in forming superficial, thyriothecial, dimidiate, circular to ellipsoid, membranous ascomata, opening by splitting of the upper wall, globose to subglobose, or ovoid, sessile asci and hyaline, oblong to clavate, or ellipsoidal, 1-septate, thick, and rough walled ascospores (Hyde et al. 2013, Phookamsak et al. 2016). However, S. pomi differs from $S$. acerinum in forming a hamathecium with septate, broadly pseudoparaphysoid-like filaments, while $S$. acerinum forms multi-loculate ascostromata, with each ascus forming in a locule, which is a "cell" in a network-like structure (Phookamsak et al. 2016). Therefore, whether $S$. pomi and $S$. acerinum are congeneric is still questionable.

The asexual morph of Schizothyrium pomi has been reported as hyphomycetous in the genus Zygophiala which was characterized by scattered, 3-4-septate, subcylindrical, flexuous conidiophores, consisting of a hyaline to subhyaline supporting cell, with a smooth, dark brown stipe, finely verruculose at apex, with a medium brown apical cell, giving rise to two (rarely three), doliiform to ellipsoid or subcylindrical, polyblastic conidiogenous cells. Scars are prominent, apically darkened, thickened and somewhat refractive, with $1(-2)$ per conidiogenous cell and conidia solitary, fusiform to obclavate, hyaline, smooth and thick-walled, 1(-7) septa, constricted at the septa, with a subtruncate base, and a darkened, thickened hilum (Batzer et al. 2005, 2008, Kirk et al. 2008, Ma et al. 2010, Hyde et al. 2013, Wijayawardene et al. 2012, 2014). The connection between Schizothyrium pomi and Zygophiala jamaicensis was first reported by Durbin et al (1953) and confirmed by Batzer et al. (2005). However, Batzer et al. (2008) later considered Z. jamaicensis as a distinct species from $S$. pomi, but these two genera were still congeneric in phylogenetic studies (Ma et al. 2010, Gao et al. 2014). Therefore, Rossman et al. (2015) proposed Schizothyrium over Zygophiala as Schizothyrium was the older name.

Schizothyrium pomi (Mont. \& Fr.) Arx, Proc. K. Ned. Akad. Wet., Ser. C, Biol. Med. Sci. 62: 336 (1959)

三Labrella pomi Mont. \& Fr., in Montagne, Annls Sci. Nat., Bot., sér. 2 1: 347 (1834)

Index Fungorum number: IF338878; Facesoffungi number: FoF03703

Figs 91, 92 
Pathogenic on apple, pear and Prunus fruits causing sooty blotch and flyspeck disease and on various other flowering plants (Farr \& Rossman 2017). Sexual morph: Ascomata 170-330 $\mu \mathrm{m}$ diameter $\times 15-30 \mu \mathrm{m}$ high [type: 160-290 $\mu \mathrm{m}$ diameter $\times 20-35 \mu \mathrm{m}$ high], scattered, solitary to gregarious, superficial, flattened, circular to ellipsoid, light brown or dark brown to black, sphaerical or orbicular, glabrous, uni-loculate, membranous, opening by splitting of the upper wall. Peridium 4-10 $\mu \mathrm{m}$ wide [type: 4-10 $\mu \mathrm{m}$ wide], thin-walled, poorly-developed at the base, comprising irregular meandering arrangement of dark brown, compact cells, membranous, in vertical section arranged in textura angularis to globulosa. Hamathecium comprising septate, broadly pseudoparaphysoid-like filaments. Asci $20-25(-30) \times 15-20(-23) \mu \mathrm{m}(\bar{x}=24 \times 18 \mu \mathrm{m}, \mathrm{n}$ $=20$ ), 8-spored, bitunicate, globose to subglobose, or ovoid, sessile, apex rounded, with an indistinct ocular chamber. Ascospores (10-)11-14(-15) $\times 3-5 \mu \mathrm{m}(\bar{x}=13 \times 5 \mu \mathrm{m}, \mathrm{n}=25)$, irregularly seriate, hyaline, oblong to clavate, 1-septate, slightly constricted at the septum, thick, and rough walled, with small guttules. Asexual morph: See notes above.

Material examined - FRANCE, Paris, on mature apple, C.P. Hussenot No. 847 (MNHN-PCPC0723481, holotype of Labrella pomi); CZECH REPUBLIC, Mähr.-Weisskirchen, Podhorn, on branches of Rubus idaeus (Rosaceae), 15 May 1922, F. Petrak (S-F7200, isotype of Microthyriella rubi).

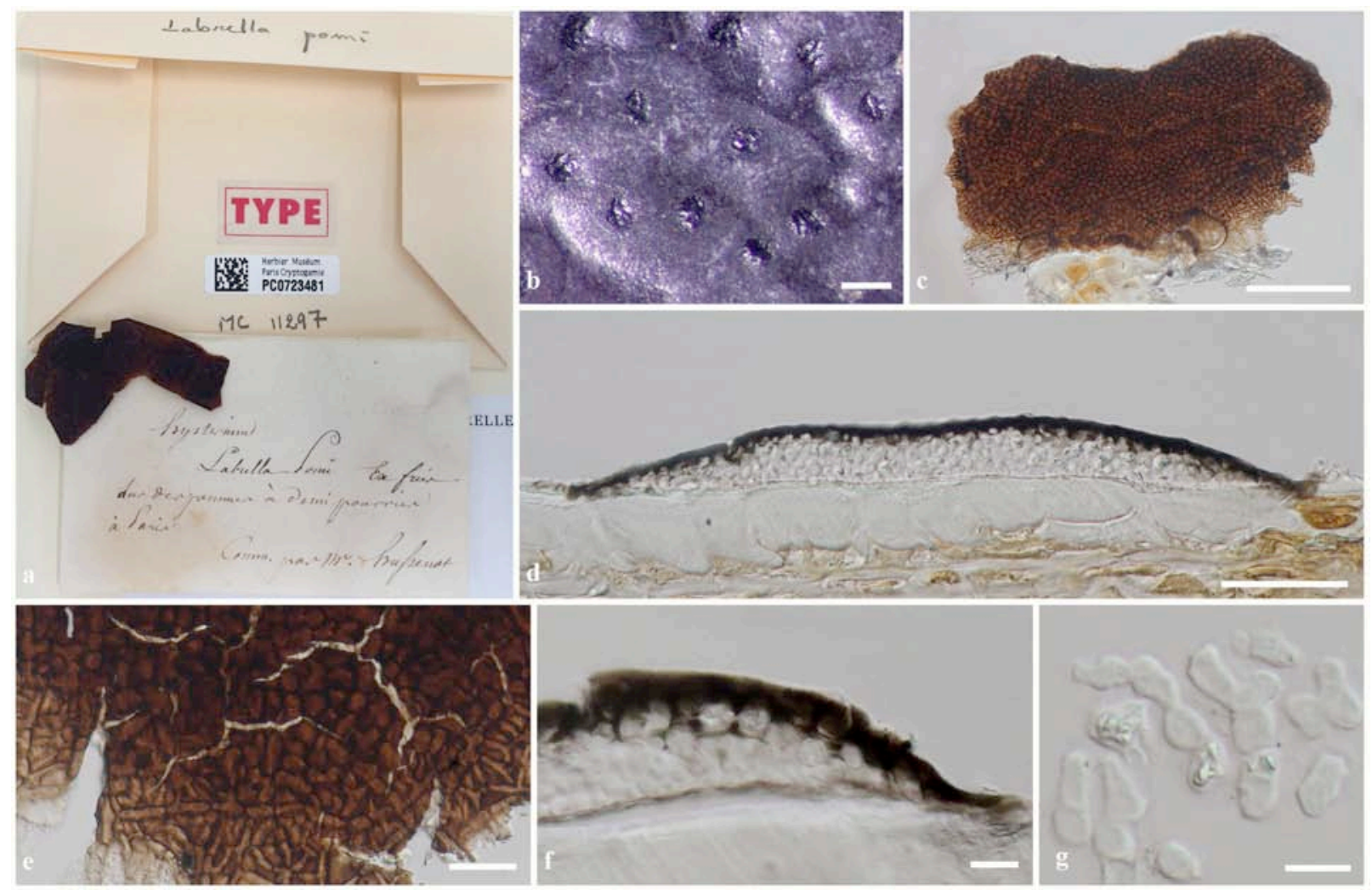

Figure 91 - Schizothyrium pomi (MNHN-PC-PC072348, holotype). a Herbarium specimen and habit on mature apple. b Appearance of ascomata. c Squash mount of ascoma. d Sections of ascoma. e Peridium structure visualized from above. f Section of peridium g Paraphysoids-like filaments. Scale bars: $\mathrm{b}=500 \mu \mathrm{m}, \mathrm{c}=100 \mu \mathrm{m}, \mathrm{d}=50 \mu \mathrm{m}, \mathrm{e}-\mathrm{g}=20 \mu \mathrm{m}$.

Stomatogeneceae Boonmee \& K.D. Hyde, fam. nov.

Index Fungorum number: IF553837; Facesoffungi number: FoF03703

Parasitic on living leaves of Asparagaceae and mosses, superficial, colonies large, subcircular, irregular, with numerous dark brown mycelium, radiating outwards, flexuous, septate. Sexual morph: Ascomata superficial, semi-immersed at the base, with a basal hypostroma developing in the host tissue, gregarious, or solitary, black, with apical pore, surrounded by dark 
brown mycelium. Peridium comprising 3-4 layers of dark pigmented cells of textura angularis, lacking pseudoparaphyses. Asci 8-spored, bitunicate, fissitunicate, subglobose, broadly ovoid to subclavate, apically thickened, with an ocular chamber, pedicel knob-like. Ascospores multiseriate, ellipsoidal oblong, upper cell slightly broader and shorter then lower cell, 1-septate, hyaline when immature and brown at maturity, verruculose, verrucose or smooth-walled. Asexual morph: Undetermined.

Family type - Stomatogene Theiss.

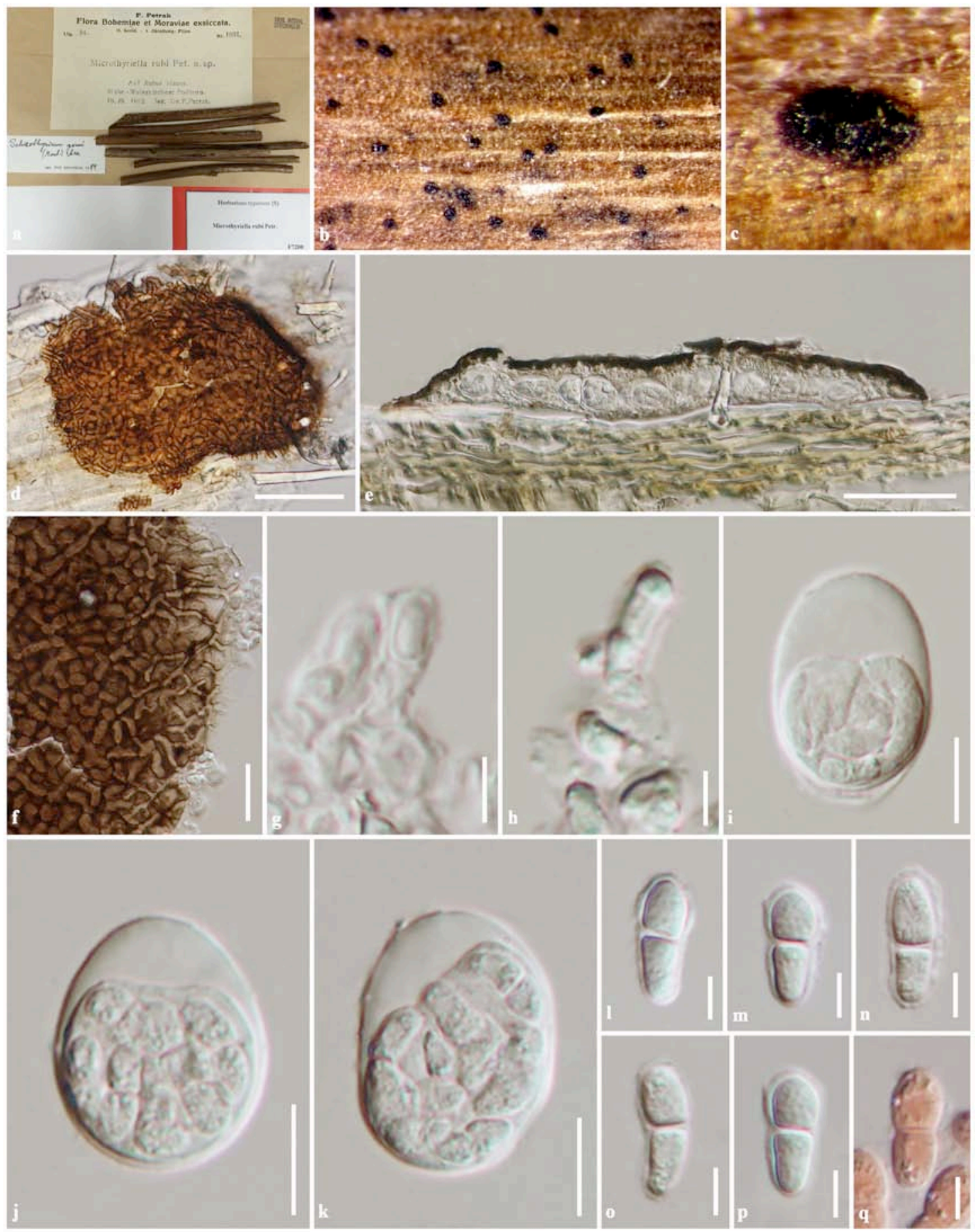

Figure 92 - Schizothyrium pomi (S-F7200, isotype of Microthyriella rubi). a Herbarium specimen and habit on branches. b, c Appearance of ascomata on branch. d Squash mount of ascoma. e Sections of ascoma. f Peridium. g, h Paraphysoids-like filaments. i-k Asci. 1-p Ascospores. $\mathrm{q}$ Ascospores stained in Congo red. Scale Bars: $\mathrm{d}, \mathrm{e}=50 \mu \mathrm{m}, \mathrm{f}=20 \mu \mathrm{m}, \mathrm{i}-\mathrm{k}=10 \mu \mathrm{m}, \mathrm{g}, \mathrm{h}, \mathrm{l}-\mathrm{q}=5$ $\mu \mathrm{m}$. 
Notes - The family Stomatogeneceae is introduced to accommodate four species from living leaves of Asparagaceae plants based on the type genus Stomatogene, while S. lycopodii was found on stems and leaves of Lycopodium cernuum (moss). The family is characterized by being parasitic, with dark superficial colonies, uniloculate, dark ascomata, subglobose, bitunicate asci and septate, hyaline to pigmented ascospores. The family differs from Pseudoperisporiaceae and other families in Dothideomycetes by its colonies, ascomata, asci and ascospore features.

Stomatogene Theiss., Annls mycol. 14(6): 406 (1917) [1916]

Parasitic on living leaves, superficial, with large colonies, subcircular, irregular, with numerous dark brown mycelium, radiating outwards, flexuous, septate. Sexual morph: Ascomata superficial, semi-immersed at the base, with a basal hypostroma developing in the host tissue, gregarious, solitary, globose to subglobose, black, with apical pore, surrounded by dark brown mycelium. Peridium comprising 3-4 layers of dark pigmented cells of textura angularis, lacking pseudoparaphyses. Asci 8-spored, bitunicate, fissitunicate, subglobose, broadly ovoid to subclavate, apically thickened, with an ocular chamber, pedicel knob-like. Ascospores multi-seriate, ellipsoidal oblong, upper cell slightly broader and shorter then lower cell, 1-septate, hyaline when immature and brown at maturity, with granulate cells, verruculose, verrucose or smooth-walled. Asexual morph: Undetermined.

Type species - Stomatogene agaves (Ellis \& Everh.) Theiss.

Notes - The genus Stomatogene was introduced by Theissen (1916) with the type species $S$. agaves on the basis of earlier name Asterina agaves Ellis \& Everh (1900). Theissen (1916) placed Stomatogene in Perisporiaceae. The genus is characterized by large colonies, superficial ascomata, with a basal hypostroma, broadly ovoid to subclavate, thick-walled asci and ellipsoidal oblong, septate, brown ascospores; an asexual morph has not been reported for this genus. The genus was later placed in the family Parodiopsidaceae by Eriksson et al. (2001), Kirk et al. (2008), Lumbsch \& Huhndorf (2010) and Hyde et al. (2013). Based on morphological characters, the new family Stomatogeneceae is introduced for the genus Stomatogene.

Stomatogene agaves (Ellis \& Everh.) Theiss., Annls mycol. 14(6): 406 (1918) [1917]

$\equiv$ Asterina agaves Ellis \& Everh., Bull. Torrey bot. Club 27: 571 (1900)

三Dimerium agaves (Ellis \& Everh.) Rehm, Annls mycol. 12(2): 170 (1914)

Index Fungorum number: IF121867; Facesoffungi number: FoF03705

Fig. 93

Parasitic on living leaves of Agave sp., superficial, with large colonies, subcircular, irregular, with numerous dark brown mycelium, radiating outwards, flexuous, septate. Sexual morph: Ascomata 80.5-104 $\mu \mathrm{m}$ diameter $\times 75-93 \mu \mathrm{m}$ high, superficial, semi-immersed at the base, with a basal hypostroma developing in the host tissue, gregarious, or solitary, globose to subglobose, black, with apical pore 17-23 $\mu \mathrm{m}$ diameter, surrounded by dark brown mycelium, $62-137 \mu \mathrm{m}$ long $\times$ 4.5-5 $\mu \mathrm{m}$ wide. Peridium 14-18 $\mu \mathrm{m}$ wide, comprising 3-4 layers of dark cells of textura angularis, outer layer dark brown cells, inner layer pine green cells, lacking pseudoparaphyses. Asci 45-66 × 23.5-32.5 $\mu \mathrm{m}(\bar{x}=57 \times 28 \mu \mathrm{m}, \mathrm{n}=10)$, 8-spored, bitunicate, fissitunicate, subglobose, broadly ovoid to subclavate, apically thickened, with an ocular chamber, 1-2(-3) $\mu \mathrm{m}$ diameter, pedicel knob-like. Ascospores 21.5-28 $\times 6-8.5 \mu \mathrm{m}(\bar{x}=24 \times 7 \mu \mathrm{m}, \mathrm{n}=10)$, overlapping 3-4-seriate, ellipsoidal oblong, upper cell slightly broader and shorter then lower cell, 1-septate, constricted and dark pigmented at the septum, hyaline when immature and brown at maturity, with granulate cells. Asexual morph: Undetermined.

Material examined - MEXICO, Sonora, in the vicinity of Álamos, on living leaves of Agave sp. L (Asparagaceae), March 1910, J.N. Rose No.13063 (NY 02977047).

Notes - We were unable to examine the holotype specimen, therefore, the description and illustration herein, is from an authentic specimen of Stomatogene agaves (NY 02977047). 


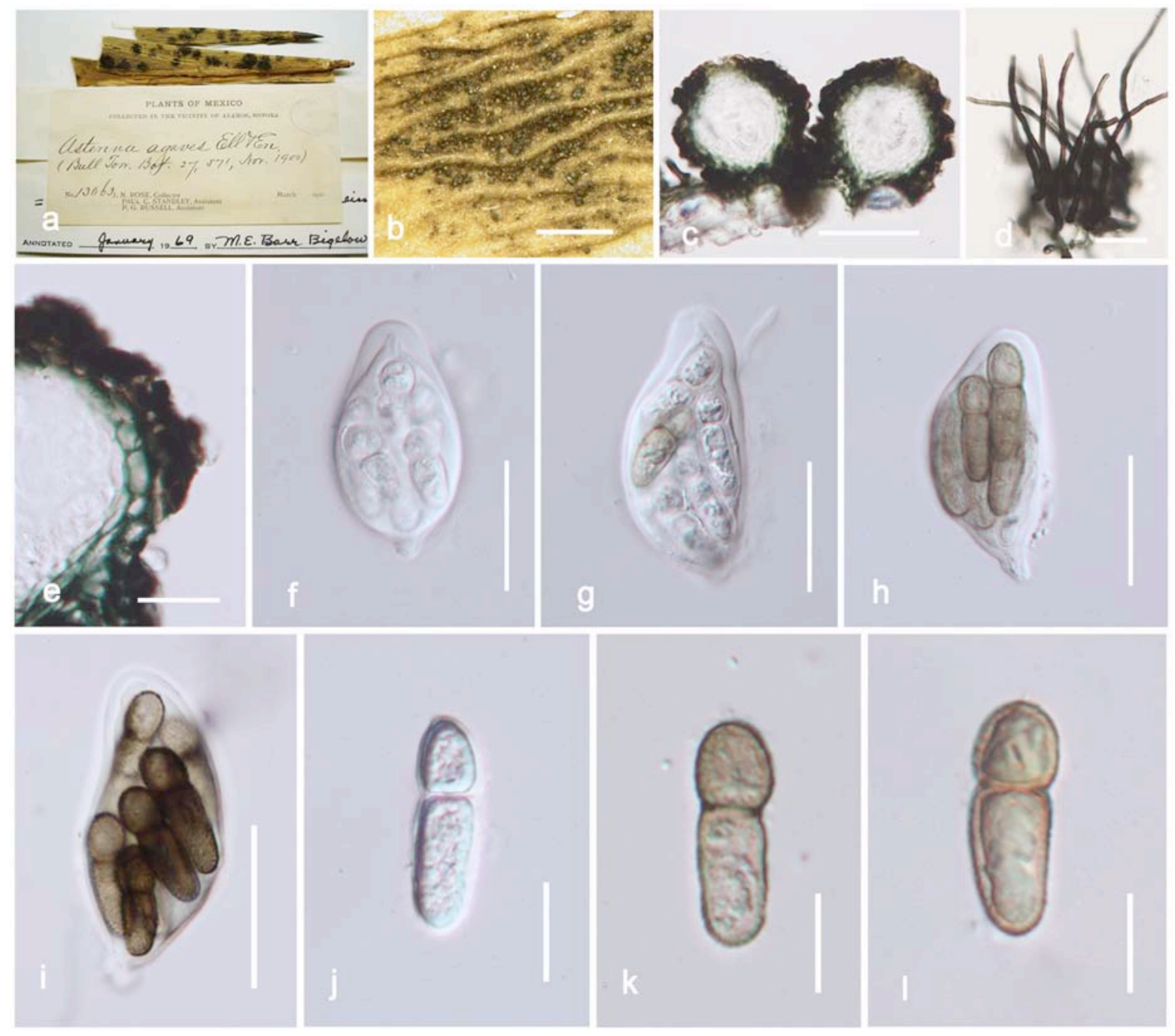

Figure 93 - Stomatogene agaves (NY 02977047). a Herbarium specimen and habit on leaves. b Appearance of ascomata. c Section of ascomata on leaf surface. $d$ Mycelium. e Peridium. $f-i$ Immature and mature asci. j-1 Ascospores. Scale bars: $b=500 \mu \mathrm{m}, \mathrm{c}, \mathrm{d}=50 \mu \mathrm{m}, \mathrm{e}-\mathrm{i}=20 \mu \mathrm{m}, \mathrm{j}-1=$ $10 \mu \mathrm{m}$.

Stomatogene yuccae Hansf., Sydowia 11(1-6): 68 (1958) [1957]

Index Fungorum number: IF306516; Facesoffungi number: FoF03706

Fig. 94

Parasitic on living leaves of Yucca mohavensis Sarg., superficial, with large colonies, dark brown, subcircular, irregular, lacking superficial hyphae. Sexual morph: Ascomata 139.5-178 $\mu \mathrm{m}$ diameter $\times 135-152 \mu \mathrm{m}$ high, superficial, seated on a subiculum, thickened at the base, gregarious, solitary, globose to subglobose, black, with apical ostiole, 25-29 $\mu \mathrm{m}$ diameter, lacking a hypostroma. Peridium 16-26 $\mu \mathrm{m}$ wide, comprising 3-4(-5) layers of dark brown cells of textura angularis, lacking pseudoparaphyses. Asci $52-88 \times 30-46 \mu \mathrm{m}(\bar{x}=69.5 \times 37.5 \mu \mathrm{m}, \mathrm{n}=20), 8$ spored, bitunicate, fissitunicate, subglobose, broadly ovoid to subclavate, apically thickened, with minute and thin ocular chamber, pedicel 6-12.5 $\mu \mathrm{m}$ long $\times 6-8 \mu \mathrm{m}$ wide, sometimes knob-like. Ascospores $27-35 \times 8-9 \mu \mathrm{m}(\bar{x}=30 \times 9 \mu \mathrm{m}, \mathrm{n}=20), 3-4$-seriate, ellipsoidal oblong, upper cell slightly broader and shorter than lower cell, 1-septate when immature, becoming 3-septate at maturity, slightly constricted at the septa, hyaline to light brown, with granulate cells, verruculose or verrucose. Asexual morph: Undetermined.

Material examined - USA, California, Camp Kearny, Sonora, on living leaves of Yucca mohavensis Sarg. (Asparagaceae), altitude 400 feet, 17 February 1929, H.E. Parks No. 3379 (Calif. Fungi 576), (NY 01047119, isotype). 
Notes - Stomatogene yuccae was introduced as a new species by Hansford (1958) [1957] and shares morphological features with the type species $S$. agaves. However, S. yuccae differs in lacking setae and having 1-3-septate, verruculose ascospores.

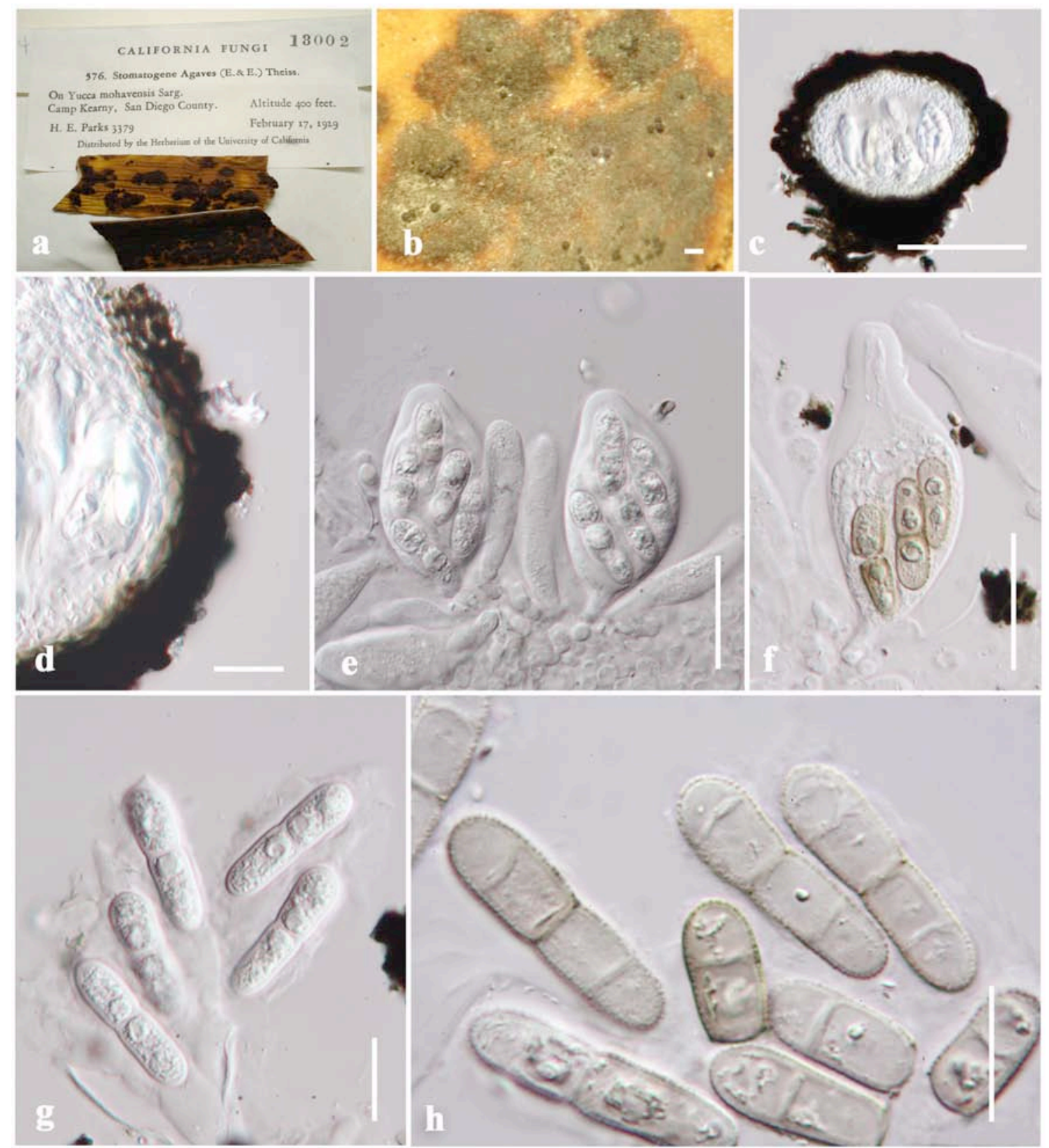

Figure 94 - Stomatogene yuccae (NY 01047119, isotype). a Herbarium specimen and habit on leaves. b Appearance of ascomata on leaf surface. c Section of ascoma. d Peridium. e, $\mathrm{f}$ Immature and mature asci. g, $\mathrm{h}$ Ascospores. Scale bars: $\mathrm{b}=200 \mu \mathrm{m}, \mathrm{c}=50 \mu \mathrm{m}, \mathrm{d}-\mathrm{f}=20 \mu \mathrm{m}, \mathrm{g}, \mathrm{h}=10 \mu \mathrm{m}$.

\section{Teratosphaeriaceae Crous \& U. Braun}

The genus Placocrea which was placed in Mycosphaerellaceae (Lumbsch \& Huhndorf 2007, 2010, Hyde et al. 2013, Wijayawardene et al. 2014), based on anastomosing pseudoparaphyses, therefore, Placocrea can be placed in Teratosphaeriaceae.

Placocrea Syd., Annls mycol. 37(4/5): 380 (1939)

Parasitic associated with living leaves. Sexual morph: Ascostromata superficial, easily removed from the host surface, orange-brown to black, flattened to slightly raised, pad-like, circular to undulate, or orbicular, yellowish to orange around the ascostromata, gregarious or 
solitary, fleshy, soft when rehydrated by water, easily cracking when dry, stromatal structure composed of palisade- to globular, orangish cells. Ascomata semi-immersed to superficial, orangeyellowish to orange-brown, globose to subglobose, or ovoid, soft and fleshy, scattered, gregarious, with apical ostiole, with thick, septate, hairy ostiole, surrounded by loose, hyphae. Peridium comprising 4-7 layers of orange-yellowish, pseudoparenchymatous cells, arranged in a textura angularis to prismatica. Hamathecium comprising dense, anastomosed, cellular pseudoparaphyses branched at the apex. Asci 8-spored, bitunicate, fissitunicate, cylindrical to cylindric-clavate or ampulliform, subsessile, apex rounded, with an indistinct ocular chamber. Ascospores overlapping 2-3-seriate, hyaline to subhyaline, becoming pale yellowish in mass, oblong to fusiform, 1-septate, upper cell larger than lower cell. Asexual morph: Undetermined.

Type species - Placocrea pulchella Syd.

Notes - Placocrea was introduced by Sydow \& Sydow (1939) as a monotypic genus to accommodate an epiphytic taxon occurring on Sarcorhachis sydowii. The genus was characterized by "ascostromata thinly crustaceous, more or less orbicular, definitely acute, with numerous ascomata in the ascostroma penetrating the leaves, dense, gregarious, globose to ovoid, lightcoloured perithecial ascomata; 8-spored, clavate to cylindric-clavate asci, with paraphyses, mucilaginous; ascospores 2-celled, hyaline" (Sydow \& Sydow 1939). Placocrea is a poorly known genus and lacks a modern taxonomic description or molecular data to clarify its natural placement. Since Sydow \& Sydow (1939) introduced the genus, which was re-described by Petrak (1952), the genus has never been re-visited. Sydow \& Sydow (1939) mentioned that the genus was closely related to Nectria based on its ascostromal characteristics. However, Petrak (1952) disagreed with Sydow \& Sydow (1939) and concluded that the genus was typical of Mycosphaerella. Therefore, Placocrea has been listed in Mycosphaerellaceae by subsequent authors (von Arx \& Müller 1975, Kirk et al. 2001, 2008, Lumbsch \& Huhndorf 2007, 2010, Hyde et al. 2013, Wijayawardene et al. 2014). Hyde et al. (2013) re-circumscribed the genera in Mycosphaerellaceae and noted that the taxonomic position of Placocrea was unproven and its placement was questionable in Mycosphaerellaceae. In this study, we examine the type specimens of Placocrea pulchella from BPI and S herbaria. Based on morphological examination, P. pulchella formed branched, anastomosing cellular pseudoparaphyses, which is different from the original description as Sydow \& Sydow (1939) mentioned its pseudoparaphyses were represented by a mucilaginous matrix. Mycosphaerellaceae is defined by small ascomata, bitunicate, cylindrical to cylindric-clavate to ampulliform, subsessile asci, lacking pseudoparaphyses and hyaline to subhyaline, fusiform, oblong to ellipsoidal, ascospores (Crous et al. 2009, Hyde et al. 2013). Placocrea can be distinguished from other genera in Mycosphaerellaceae by the presence of pseudoparaphyses. Placocrea is therefore treated in Teratosphaeriaceae based on its life mode as parasites and anastomosing pseudoparaphyses (Hyde et al. 2013).

Placocrea pulchella Syd., Annls mycol. 37(4/5): 380 (1939)

Index Fungorum number: IF275600; Facesoffungi number: FoF03717

Fig. 95

Parasitic associated with living leaves of Sarcorhachis sydowii Trel. Sexual morph: Ascostromata $1.5-3 \mathrm{~mm}$ diameter $\times 1.5-4.5 \mathrm{~mm}$ long, superficial, easily removed from the host surface, orange-brown to black, flattened to slightly raised, pad-like, a circular to undulate area, or orbicular, with yellowish to orangish around the ascostromata, clustered or solitary, gregarious, fleshy, soft when rehydrated by water, easily cracking when dry, stromatal structure composed of palisade- to globular, orangish cells. Ascomata 70-110 $\mu \mathrm{m}$ diameter $\times 70-120 \mu \mathrm{m}$ high, semiimmersed to superficial, orange-yellowish to orange-brown, globose to subglobose, or ovoid, soft and fleshy, scattered, gregarious, with apical ostiole, with thick, septate hairy ostiole, surrounded by loose hyphae. Peridium 7-23 $\mu \mathrm{m}$ wide, comprising 4-7 layers of orange-yellowish, pseudoparenchymatous cells, arranged in a textura angularis to prismatica. Hamathecium $1-2 \mu \mathrm{m}$ wide, comprising dense, apically branched, anastomosed, cellular pseudoparaphyses. Asci (32-)35$45(-50) \times 8-10(-12) \mu \mathrm{m}(\bar{x}=39.5 \times 10 \mu \mathrm{m}, \mathrm{n}=25), 8$-spored, bitunicate, fissitunicate, cylindrical to cylindric-clavate or ampulliform, subsessile, apex rounded, with an indistinct ocular chamber. 
Ascospores 10-13(-15) $\times 3-4 \mu \mathrm{m}(\bar{x}=12.5 \times 3.5 \mu \mathrm{m}, \mathrm{n}=30)$, overlapping $2-3$-seriate, hyaline to subhyaline, becoming pale yellowish in mass, oblong to fusiform, with rounded to acute ends, 1septate, constricted at the septum, smooth and thick-walled, upper cell larger than lower cell. Asexual morph: Undetermined.

Material examined - ECUADOR, Pichincha Province, near Mindo, alt. m. 1200-1300, on Sarcorhachis sydowii Trel. (Convolvulaceae), 28 October 1937, H. Sydow 252 (S-F44505, syntype); ibid. on leaves of Sarcorhachis sydowii, 6 November 1937, H. Sydow (BPI 631051, holotype).

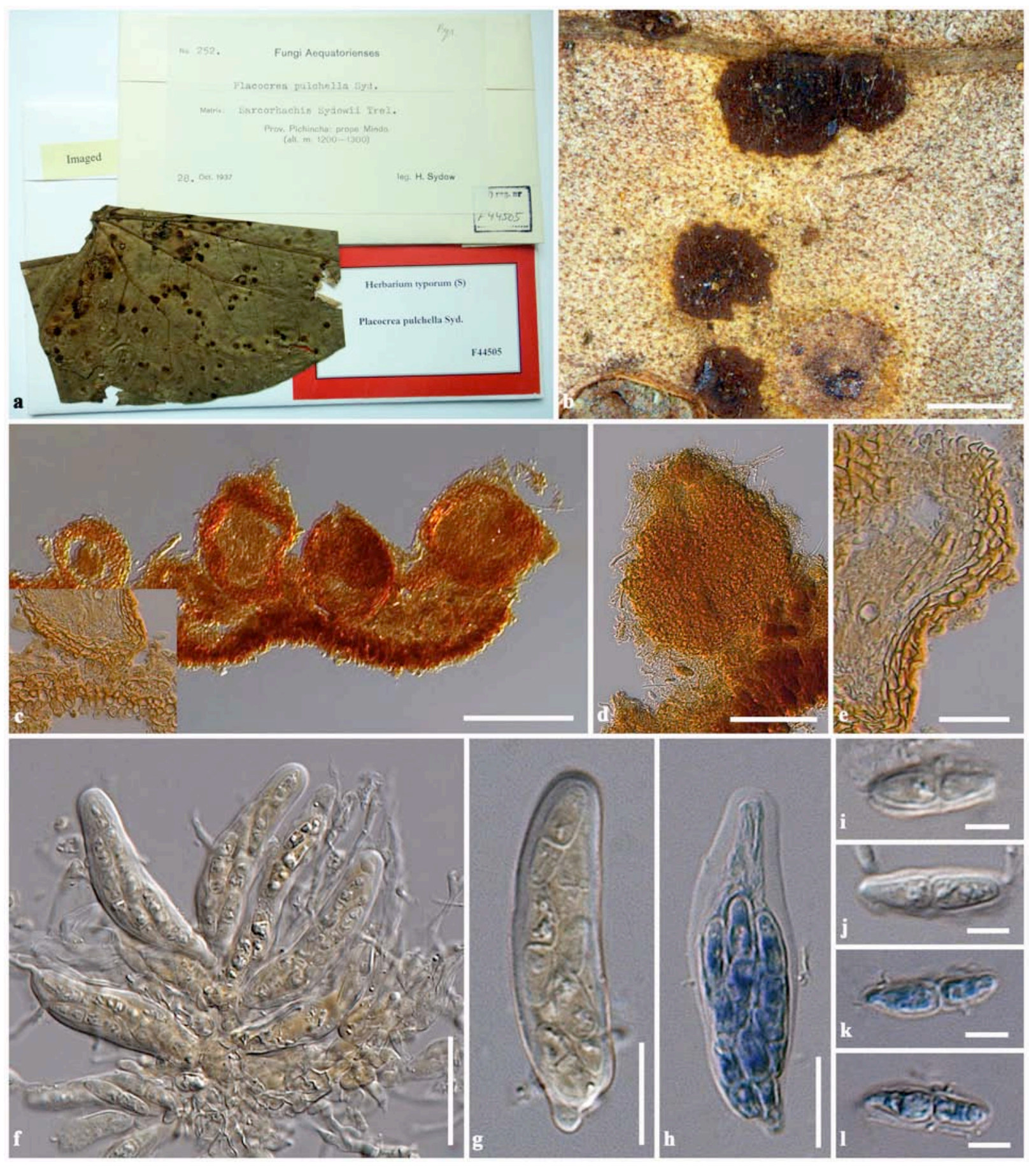

Figure 95 - Placocrea pulchella (S-F44505, syntype). a Herbarium specimen and habit on leaves. b Appearance of ascostromata on leaf surface. c Section of ascostroma. d Squash mount of ascoma. e Peridium. f Asci with pseudoparaphyses. g Ascus. h Ascus stained in cotton blue. i-1 Ascospores stained in cotton blue. Scale bar: $\mathrm{b}=2000 \mu \mathrm{m}, \mathrm{c}=100 \mu \mathrm{m}, \mathrm{d}-\mathrm{f}=20 \mu \mathrm{m}, \mathrm{i}-\mathrm{l}=5 \mu \mathrm{m}$. 
Toroaceae Boonmee \& K.D. Hyde, fam. nov.

Index Fungorum number: IF553838; Facesoffungi number: FoF03708

Saprobic on dried leaves. Sexual morph Ascomata superficial, globose to subglobose, solitary to gregarious, scattered, black, with a subiculum, collapsing when dry, with apical ostiole. Peridium comprising red brown to dark brown cells of textura angularis. Asci 4-spored, bitunicate, oblong-ellipsoid to ovoid, sessile, apically thickened. Ascospores 2-seriate, ellipsoid-fusiform, narrow towards the ends, pale brown to orange brown, light at both ends, smooth-walled. Asexual morph Undetermined.

Family type - Toroa Syd.

Notes - Toroaceae is introduced to accommodate the genus Toroa based on the type species Toroa dimerosporioides. The family is characterised by superficial, sphaerical, dark brown, ascomata with setae, 4-spored per asci, and multi-septate, pigmented ascospores. Toroa differs from other families in the Dothideomycetes by having only four ascospores in the ascus and a combination of other characters.

Toroa Syd., in Toro, J. Dept. Agric. Porto Rico 10(2): 19 (1926)

Saprobic on dead leaves. Sexual morph: Ascomata superficial, globose to subglobose, solitary to gregarious, scattered, black, with a subiculum, collapsing when dry, with apical ostiole. Peridium comprising red brown to dark brown cells of textura angularis. Asci 4-spored, bitunicate, oblong-ellipsoid to ovoid, sessile, apically thickened. Ascospores 2-seriate, ellipsoid-fusiform, narrow towards the ends, 2-3-septate, constricted at the septa, pale brown to orange brown, light at both ends, smooth-walled. Asexual morph: Undetermined.

Type species - Toroa dimerosporioides (Speg.) Syd. [as 'dimerosporoides']

Notes - Sydow (in Toro 1926) revised five taxa on the same host family Bromeliaceae, Asteridium dimerosporioides, Zukalia dimerosporioides, Gibberella dimerosporoides, Perisporium bromeliae and Chaetosphaeria bromeliae and found that all are the same fungus. Therefore, Sydow (1926) introduced the genus Toroa to accommodate this fungus under the name Toroa dimerosporioides, as type species. (type species) and separated it from the genera Asteridium, Chaetosphaeria, Gibberella, Perisporium and Perisporium (Spegazzini 1888, Saccardo 1891, von Höhnel 1907, Stevens 1917, González Fragoso \& Ciferri 1925, Toro 1926). Hansford (1946) reexamined three specimens Asteridium dimerosporioides (no. 4059, holotype), Perisporium bromeliae (no. 136) and Chaetosphaeria bromeliae (no 7034), and confirmed that all taxa are the same fungus. Furthermore, Toroa saurauiae (Basionym: Meliolina saurauiae Stev. \& Rold.) was added to the genus, but its basionym was invalid (Art. 39.1, Melbourne). Barr (1997) included Toroa in the family Pseudoperisporiaceae. The genus is characterized by superficial ascomata, bitunicate asci, lacking pseudoparaphyses, four spores per asci and 2-3-septate, pale brown to orange brown ascospores which are light at both ends. These characters can distinguish Toroa from other genera in Pseudoperisporiaceae and other families in the Dothideomycetes. The genus is therefore placed in its own family Toroaceae.

Toroa dimerosporioides (Speg.) Syd. [as 'dimerosporoides'], J. Dept. Agric. Porto Rico 2: 20 (1926)

三Asteridium dimerosporioides Speg., Anal. Soc. cient. argent. 26(1): 19 [no. 50] (1888)

= Zukalia dimerosporioides (Speg.) Sacc., Syll. fung. (Abellini) 9: 434 (1891)

= Gibberella dimerosporoides (Speg.) Höhn., Sber. Akad. Wiss. Wien, Math.-naturw. K1., Abt. 1 116: 617 (1907)

= Botryosphaeria dimerosporoides (Speg.) Weese, Sber. Akad. Wiss. Wien, Math.-naturw. K1., Abt. 1 128: 708 (1919)

= Perisporium bromeliae F. Stevens, Trans. Ill. St. Acad. Sci. 10: 168 (1917)

$=$ Chaetosphaeria bromeliae Gonz. Frag. \& Cif., Boln Real Soc. Españ. Hist. Nat., Biologica 25: 449 (1925)

Index Fungorum number: IF263219; Facesoffungi number: FoF03245

Figs 96, 97 
Saprobic on dead leaves of Bromelia penguin. Sexual morph: Ascomata 99-119 $\mu$ m diameter $\times$ 111-122 $\mu \mathrm{m}$ high, superficial, globose to subglobose, solitary to gregarious, scattered, black, with a subiculum, collapsing when dry, with apical ostiole. Peridium 14.5-20 $\mu \mathrm{m}$ wide, comprising 3-4 layers of red brown to dark brown cells of textura angularis. Asci (59.5-)67-72(-75) $\times(22-$ 26-30(-33) $\mu \mathrm{m}(\bar{x}=68 \times 28 \mu \mathrm{m}, \mathrm{n}=10)$, 4-spored, bitunicate, oblong-ellipsoid to ovoid, sessile, apically thickened. Ascospores (32-)35-38(-75) $\times(9.5-) 10-12 \mu \mathrm{m}(\bar{x}=35 \times 11 \mu \mathrm{m}, \mathrm{n}=10), 2-$ seriate, ellipsoid-fusiform, narrow ends, 2-3-septate, constricted at the septa, pale brown to orange brown, light both ends, smooth-walled. Asexual morph: Undetermined.

Material examined - PARAGUAY, Paraguarí, on leaves of Bilbergia / Pitcarinia sp. (Bromeliaceae), October 1893, B. Balansa, BAFC / LPS673 under the name Zukalia dimerosporioides (Speg.) Sacc. and PUERTO RICO, La Vega, on dried leaves Bromelia pinguin L. (Bromeliaceae), 19 March 1919, Kern and R.A. Toro (No. 207 / No. I.T.A 5413, BPI 692120)

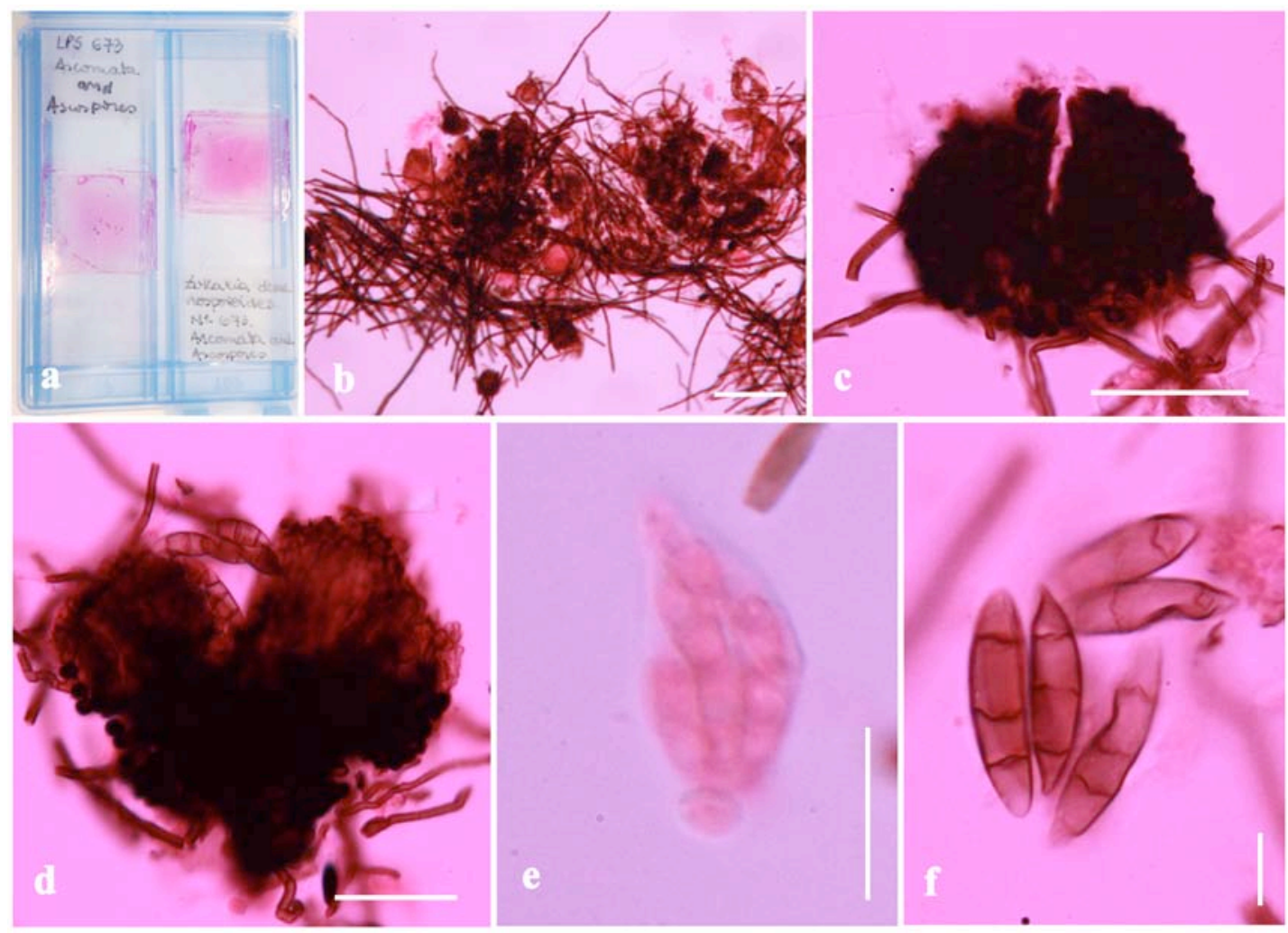

Figure 96 - Toroa dimerosporioides (BAFC / LPS673). a Slide specimens. b Squash mount of ascomata with aerial hyphae. $\mathrm{c}, \mathrm{d}$ Squash mount of ascomata. e Ascus. f Ascospores. Scale bars: $\mathrm{a}=$ Specimen, $\mathrm{b}=100 \mu \mathrm{m}, \mathrm{c}, \mathrm{d}=50 \mu \mathrm{m}, \mathrm{e}=20 \mu \mathrm{m}, \mathrm{f}=10 \mu \mathrm{m}$.

\section{Venturiaceae E. Müll. \& Arx ex M.E. Barr}

Three genera Dimeriella and Neocoleroa are placed in the family Venturiaceae based on features of ascomata and ascospores (Zhang et al. 2011, Hyde et al. 2013).

Dimeriella Speg., Revta Mus. La Plata 15(2): 12 (1908)

Saprobic on dead leaves. Sexual morph: Ascomata superficial, solitary, scattered, globose to subglobose, black, covered by hyaline mycelium, with sparse setae, olivaceous to dark brown, tapering towards the subacute apex, septate. Peridium 10-13 $\mu \mathrm{m}$ wide, comprising dark brown cells of textura angularis, inner layers reddish-brown, lacking pseudoparaphyses. Asci 8-spored, bitunicate, fissitunicate, ovoid-subclavate, sessile, apically thickened. Ascospores 2-seriate, 1septate, constricted at the septum, hyaline, becoming brownish at maturity, smooth-walled. Asexual morph: Undetermined.

Type species - Dimeriella hirtula Speg. 


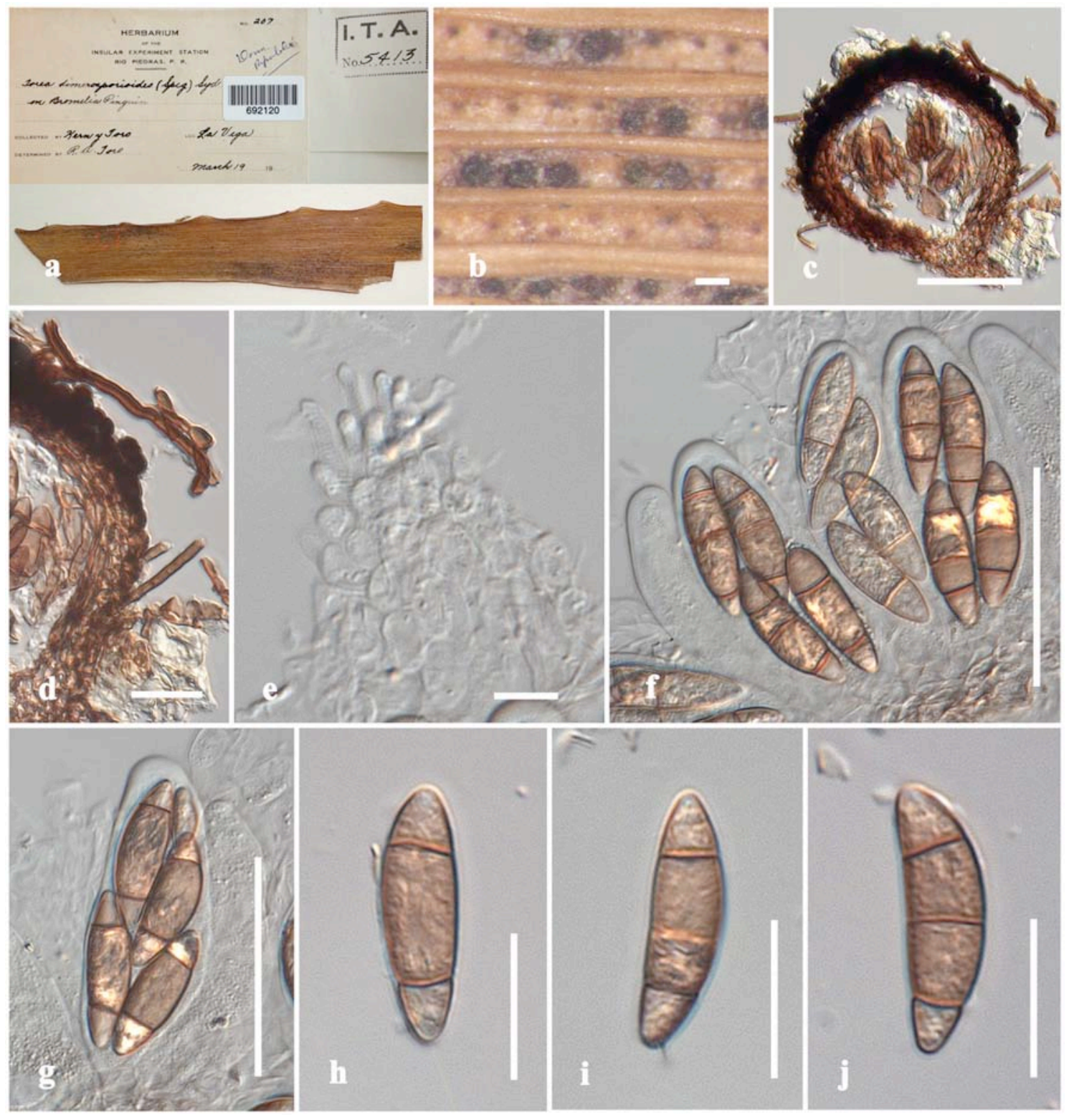

Figure 97 - Toroa dimerosporioides (BPI 692120). a Herbarium specimen and habit on leaf. b Appearance of ascomata on leaf surface. c Section of ascoma. d Peridium. e Cells of hamathecium in gelatinous matrix. $\mathrm{f}, \mathrm{g}$ Asci. $\mathrm{h}-\mathrm{j}$ Ascospores. Scale bars: $\mathrm{a}=$ Material label, $\mathrm{b}=100 \mu \mathrm{m}, \mathrm{c}, \mathrm{f}, \mathrm{g}=$ $50 \mu \mathrm{m}, \mathrm{d}, \mathrm{h}-\mathrm{j}=20 \mu \mathrm{m}, \mathrm{e}=10 \mu \mathrm{m}$.

Notes - Spegazzini (1908) introduced the genus Dimeriella based on the type species $D$. hirtula which he separated from Dimerosporium. Typically, the ascomata are small, subglobose, darkly pigmented, with sparse dark brown and short setae and lack pseudoparaphyses. The genus Dimeriella and its type species, D. Hirtula, have been re-examined and compared with several genera and families based on some similar morphology (Theissen \& Sydow 1917, Toro 1939, Hansford 1946, Müller \& von Arx 1962, Farr 1963, 1965). Farr (1979) re-examined and described several didymosporous dimeriaceous fungi on the host family Asteraceae, and he excluded the genus Dimeriella from the family Dimeriaceae based on the centrum structure of the type species, D. hirtula. Hyde et al. (2013), included Dimeriella in the family Perisporiopsidaceae (= Parodiellinaceae G. Arnaud) based on its habitat and characteristics. Dimeriella shares several characters in common with genera in Venturiaceae such as superficial, dark pigmented, sparse, short setae, and 1-septate, hyaline to brown ascospores.

Dimeriella hirtula Speg. Revta Mus. La Plata 15(2): 12 (1908) 
Index Fungorum number: IF168238; Facesoffungi number: FoF03709

Fig. 98

Saprobic on dead leaves of Baccharis brevifolia DC. Sexual morph: Ascomata 80-82 $\mu \mathrm{m}$ diameter $\times 80-86.5 \mu \mathrm{m}$ high, superficial, solitary, scattered, globose to subglobose, black, covered by hyaline mycelium, with sparse setae, $21-39(-43) \mu \mathrm{m}$ long, olivaceous to dark brown, tapering towards the subacute apex, septate. Peridium 10-13 $\mu \mathrm{m}$ wide, comprising dark brown cells of textura angularis, inner layers reddish-brown, lacking pseudoparaphyses. Asci (32-)35-46(-49) $\times$ 14-19.5(-20.5) $\mu \mathrm{m}(\bar{x}=40 \times 17 \mu \mathrm{m}, \mathrm{n}=10), 8$-spored, bitunicate, fissitunicate, ovoid-subclavate, sessile, apically thickened. Ascospores (13-)15-18 $\times 5-8 \mu \mathrm{m}(\bar{x}=15 \times 6 \mu \mathrm{m}, \mathrm{n}=20), 2$-seriate, 1 septate, constricted at the septum, hyaline, becoming brownish at maturity, smooth-walled. Asexual morph: Undetermined.

Material examined - BRAZIL, Sierra de Itatiaya, on leaves of Baccharis brevifolia DC. (Asteraceae), June 1902, P. Dusen Nr. 662 (FH, isotype).
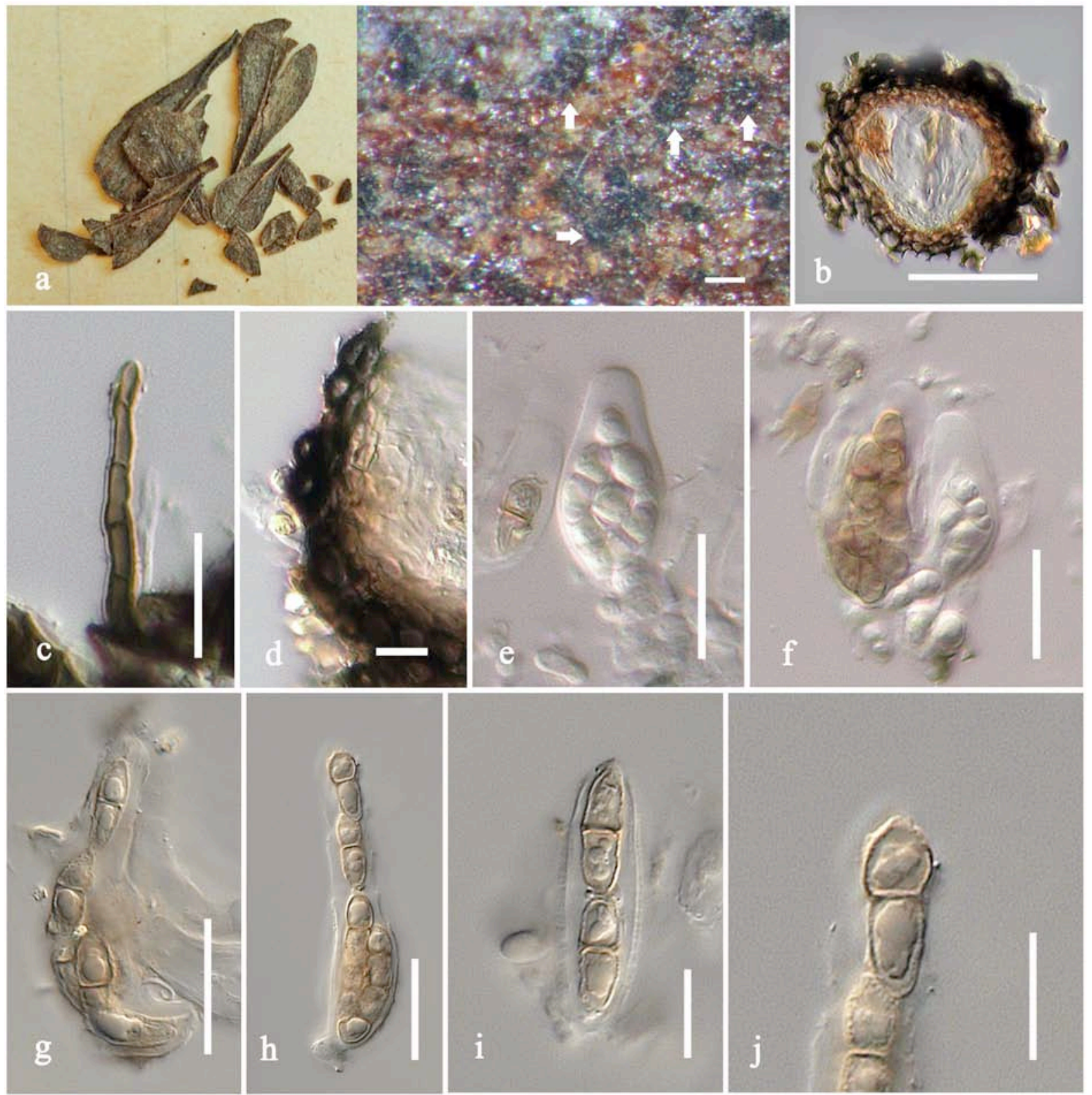

Figure 98 - Dimeriella hirtula (Nr. 662 (FH), isotype). a Herbarium specimen and habitat on leaves. b Appearance of ascomata on leaf surface. c Section of ascoma. d Seta. e Peridium. $\mathrm{f}-\mathrm{h}$ Asci. i, j Ascospores. Scale bars: $\mathrm{b}=100 \mu \mathrm{m}, \mathrm{c}=50 \mu \mathrm{m}, \mathrm{d}, \mathrm{f}-\mathrm{h}=20 \mu \mathrm{m}, \mathrm{e}, \mathrm{i}, \mathrm{j}=10 \mu \mathrm{m}$.

Neocoleroa Petr., Hedwigia 74: 39 (1934) 
Saprobic on dead branches of dicotyledons. Sexual morph: Ascomata superficial, solitary, or scattered, uniloculate, on sparse subiculum, dark brown to black, globose to subglobose, surrounded by dark brown and stiff setae, septate, tapering towards an acute apex, short papillate, with apical ostiole, 20-25 $\mu \mathrm{m}$ diameter. Peridium comprising dark brown cells of textura angularis. Hamathecium comprising numerous, cylindrical, filiform, septate, hyaline pseudoparaphyses. Asci 8-spored, bitunicate, cylindrical-subclavate, saccate to narrowly clavate, sessile or with short pedicel. Ascospores biseriate, narrow ellipsoid-fusiform, oblong to obovate, 1septate, hyaline. Asexual morph: Undetermined.

Type species - Neocoleroa sibirica Petr.

Notes - Neocoleroa was established by Petrak (1934) to accommodate a single species $N$. sibirica and is characterized by ascomata covered by numerous stiff setae, bitunicate asci and 1septate, hyaline ascospores. von Arx \& Müller (1975) synonymised Neocoleroa under Wentiomyces in the family Dimeriaceae. Barr (1997) later placed it in the family Pseudoperisporiaceae. The genus comprises eleven epithets, but only three species are presently recognized in the genus, while the other eight taxa having superficial ascomata, with dark brown setae, bitunicate asci and 1-septate, hyaline ascospores were placed in Wentiomyces (Index Fungorum 2017). Neocoleroa metrosideri (KU131677) was classified with phylogenetic analysis of LSU data and placed in the family Sympoventuriaceae (Johnston \& Park 2016). Johnston \& Park (2016) introduced a species Neocoleroa metrosideri based on the characterictics of setae which Barr (1997) described. The recent illustration of the type specimen Neocoleroa sibirica from W (Krypto 1978-0007650) show ascomata, asci, ascospores and setae as morphology different from N. metrosideri and the description in Barr (1997). Based on morphological characters of the type specimen, Neocoleroa sibirica differs from the taxa in Sympoventuriaceae. Therefore, we suggest that Neocoleroa should be placed in Venturiaceae rather than Sympoventuriaceae, however the type species needs recollecting and sequencing to confirm this.

Neocoleroa sibirica Petr., Hedwigia 74: 38 (1934)

=Wentiomyces sibiricus (Petr.) E. Müll., in Müller \& von Arx 1962

Index Fungorum number: IF278078; Facesoffungi number: FoF03707

Fig. 99

Saprobic on dead branches of Vaccinium myrtillus L. Sexual morph: Ascomata 114-143 $\mu \mathrm{m}$ diameter $\times 105-117.5 \mu \mathrm{m}$ high, superficial, solitary, scattered, uniloculate, with sparse subiculum, dark brown to black, globose to subglobose, surrounded by dark brown and stiff setae, 70-117.5 $\mu \mathrm{m}$ long $\times 5-12.5 \mu \mathrm{m}$ wide, septate, tapering towards the acute apex, short papillate, with apical ostiole, 20-25 $\mu \mathrm{m}$ diameter. Peridium 20-25 $\mu \mathrm{m}$ wide, comprising 2-3(-4) layers of dark brown cells of textura angularis. Hamathecium comprising numerous, cylindrical, filiform, septate, hyaline pseudoparaphyses. Asci 40-52.5 $\times 5-10 \mu \mathrm{m}(\bar{x}=48 \times 7 \mu \mathrm{m}, \mathrm{n}=20), 8$-spored, bitunicate, cylindrical-subclavate, saccate to narrowly clavate, sessile or with short pedicel. Ascospores 10$12.5 \times 2.5 \mu \mathrm{m}(\bar{x}=11 \times 2.5 \mu \mathrm{m}, \mathrm{n}=20)$, biseriate, narrowly ellipsoid-fusiform, oblong to obovate, 1-septate, constricted at the septum, hyaline, smooth-walled. Asexual morph: Undetermined.

Material examined - RUSSIA, Russian Federation, Siberian Federal District, on dead branches of Vaccinium myrtillus L. (Ericaceae), 22 July 1927, K.E. Murashkinsky (No. 20a), (W Krypto 1978-0007650, holotype).

\section{Dothideomycetes genera, incertae sedis}

The following genera have few distinguishing characters, therefore, we treat these in Dothideomycetes genera, incertae sedis.

Eumela Syd., Annls mycol. 23(3/6): 335 (1925)

Parasitic on living leaves, superficial, colonies large, irregular, black, numerous superficial mycelium forming a network, dark brown outwardly. Sexual morph: Ascomata superficial, solitary, scattered, globose to subglobose, black, surrounded by brown to dark brown appendaged hyphae, 

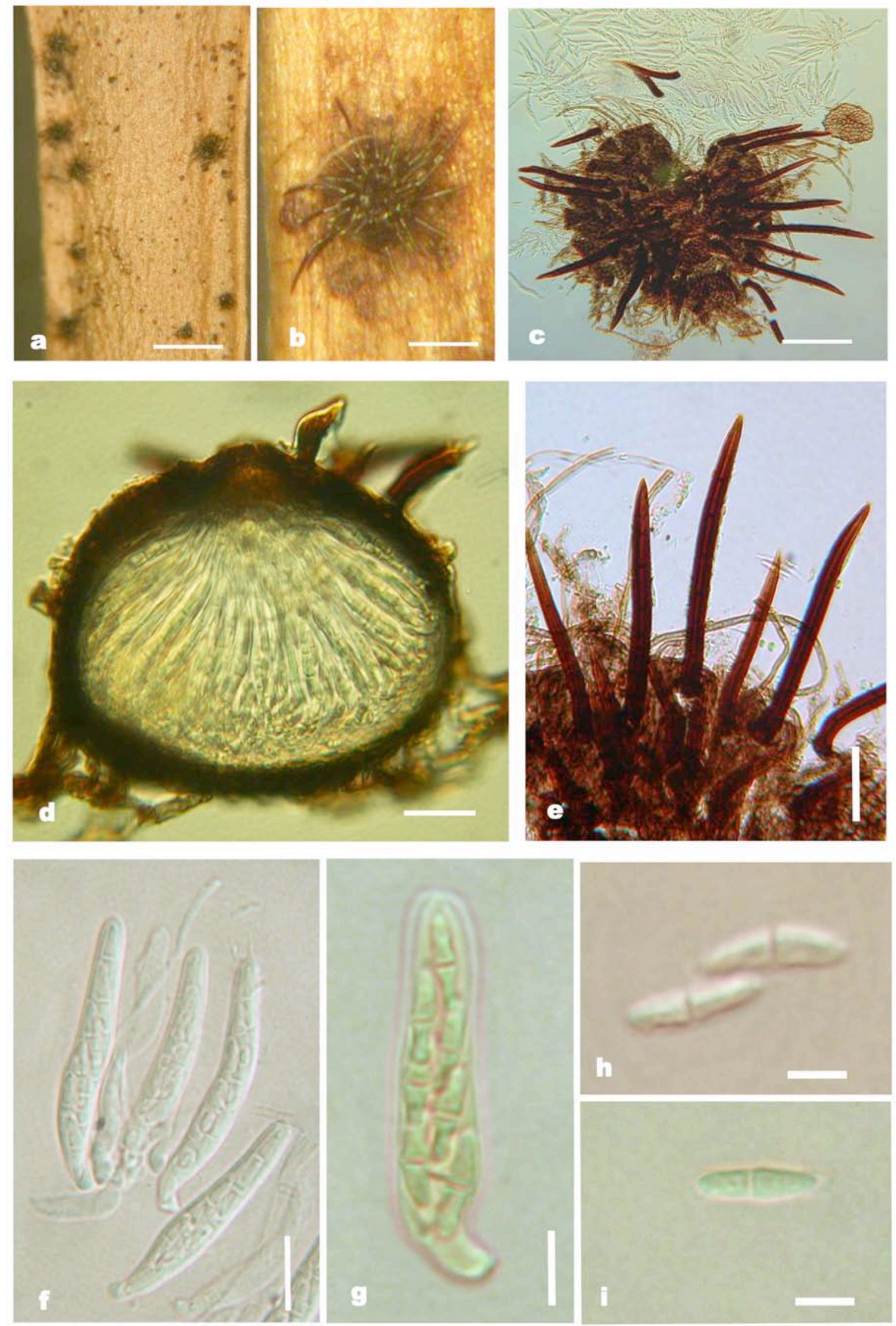

Figure 99 - Neocoleroa sibirica (W Krypto 1978-0007650, holotype). a Herbarium specimen and habit on branch. b Appearance of ascoma on branch. c Squash mount of ascoma with setae. d Section of ascoma and peridium. e Close up of setae. $f, g$ Asci. h, i Ascospores. Scale bars: $a-e, g-j$ $=25 \mu \mathrm{m}, \mathrm{f}=5 \mu \mathrm{m}, \mathrm{k}-1=2.5 \mu \mathrm{m}$. 
longer than $100 \mu \mathrm{m}$, branched, septate. Peridium comprising brown cells of textura angularis to subglobosa, lacking pseudoparaphyses. Hairy hyphae longer than $100 \mu \mathrm{m}$, pale brown to dark brown, simple, unbranched, numerous, straight or curved, septate, gradually paler upwards, flexuous, slightly constricted at the septa, apex rounded. Asci 8-spored, bitunicate, broadly-clavate, obovate or subglobose, sessile, slightly thickened near the apex. Ascospores multi-seriate, oblong to ovoid oblong, ends rounded, 1-septate usually towards the lower end (occasionally median), slightly constricted at the septum, hyaline, smooth-walled. Asexual morph: Undetermined.

Type species - Eumela chiococcae Syd.

Notes - The genus Eumela was introduced by Sydow (1925) with E. chiococcae as the type species. It has been placed in Pseudoperisporiaceae in Lumbsch \& Huhndorf (2010), Hyde et al. (2013) and Wijayawardene et al. (2014). This genus is characterized by superficial ascomata, with appendaged hyphae, broadly obovoid asci, with hyaline to smoky or brown, 1-septate ascospores (Sydow 1925, Farr 1984, Hyde et al. 2013). Eumela is closely related to Episphaerella Petr., Eudimeriolum Speg. and Lasiostemma Theiss. \& Syd., but it differs from these genera as its hyphae do not form on a cuticular layer, but penetrate the epidermal cells (including stomata and guard cells) by delicate hyphae which may form haustoria; hyphae of Episphaerella form extensive mycelium throughout the leaf tissues, but usually with only limited superficial mycelium. The hyphae of Eudimeriolum are entirely superficial or penetrating trichomes. The hyphae of Lasiostemma form a discrete hyphal layer in or under the cuticle (Farr 1984, Barr 1987). There are no reports of an asexual morph and no sequence data in NCBI database (http://www.ncbi.nlm.nih.gov/). Therefore, we treat Eumela in Dothideomycetes genera, incertae sedis.

Eumela chiococcae Syd., Annls mycol. 23(3/6): 335 (1925)

Index Fungorum number: IF260515; Facesoffungi number: FoF03713

Figs 100, 101

Parasitic on living leaves of Chiococca racemosa, superficial, colonies large, irregular, black, with numerous superficial mycelium forming a network, dark brown outwardly. Sexual morph: Ascomata 49-54 $\mu \mathrm{m}$ diameter $\times 48-54.5 \mu \mathrm{m}$ high, superficial, solitary, scattered, globose to subglobose, black, surrounded by brown to dark brown appendaged hyphae, longer than $100 \mu \mathrm{m}$, branched, septate. Peridium comprising brown cells of textura angularis to subglobosa, lacking pseudoparaphyses. Hairy hyphae longer than $100 \mu \mathrm{m}$, pale brown to dark brown, simple, unbranched, numerous, straight or curved, septate, gradually paler upwards, flexuous, slightly constricted at the septa, apex rounded. Asci 20-23(-25) $\times(7-) 8.5-12 \mu \mathrm{m}(\bar{x}=22 \times 9.5 \mu \mathrm{m}, \mathrm{n}=$ 10), 8-spored, bitunicate, broadly clavate, obovate or subglobose, sessile, slightly thickened near the apex. Ascospores 9-12 $\times 2-4 \mu \mathrm{m}(\bar{x}=11 \times 3 \mu \mathrm{m}, \mathrm{n}=10)$, multi-seriate, oblong to ovoid oblong, ends rounded, 1-septate usually towards lower end (occasionally median), slightly constricted at the septum, hyaline, smooth-walled. Asexual morph: Undetermined.

Material examined - COSTA RICA, Alajuela, Grecia, on living leaves of Chiococca racemosa L., (Rubiaceae), 19 January 1925, H. Sydow, Poelt \& Scheuer, Reliqu. Petrak. nr. 1620, $(\mathrm{S}-\mathrm{F} 11418$, holotype = BPI 626994, isotype).

Leptomeliola Höhn. Sber. Akad. Wiss. Wien, Math.-naturw. Kl., Abt. 1 128: 557 (1919)

Parasitic on living leaves. Colonies superficial, with radiating mycelium, branched, septate, dark brown, numerous with hyphopodia, with long setae, tapering towards apex narrow and obtuse, slightly curved, septate, dark brown. Sexual morph: Ascomata superficial, subglobose, papillate. Asci 8-spored. Ascospores somewhat small, oval ellipsoid, 4-celled, transparent, colourless. Asexual morph: Undetermined.

Type species - Leptomeliola hyalospora (Lév.) Höhn.

Notes - Leptomeliola was introduced by von Höhnel (1919) based on type species $L$. hyalospora (= Meliola hyalospora Lév.) and separated from the genus Meliola based on bitunicate asci. The genus Leptomeliola has been revised and synonymised with other genera by some mycologists (Hughes 1993, Eriksson \& Hawksworth 1993). Barr (1997) revised several genera and 
placed Leptomeliola in Pseudoperisporiaceae. Kirk et al. (2008) and Lumbsch \& Huhndorf (2010) placed this genus in Parodiopsidaceae. Silvério et al. (2011) found L. uvariae in South America and clearly described asci as clavate and bitunicate. Recent studies based on molecular phylogeny indicated that Leptomeliola ptilidii clustered with the clade of Epibryon, Epibryaceae (Stenroos et al. 2010, Gueidan et al. 2014). However, the morphological features of Leptomeliola ptilidii of the strain no. M186 from Finland was not seen in Stenroos et al. (2010) and Gueidan et al. (2014). Leptomeliola is rather atypical for the families Epibryaceae and Perisporiopsidaceae by its hyphal colonies and ascospore features. We therefore treat Leptomeliola in Dothideomycetes genera, incertae sedis.

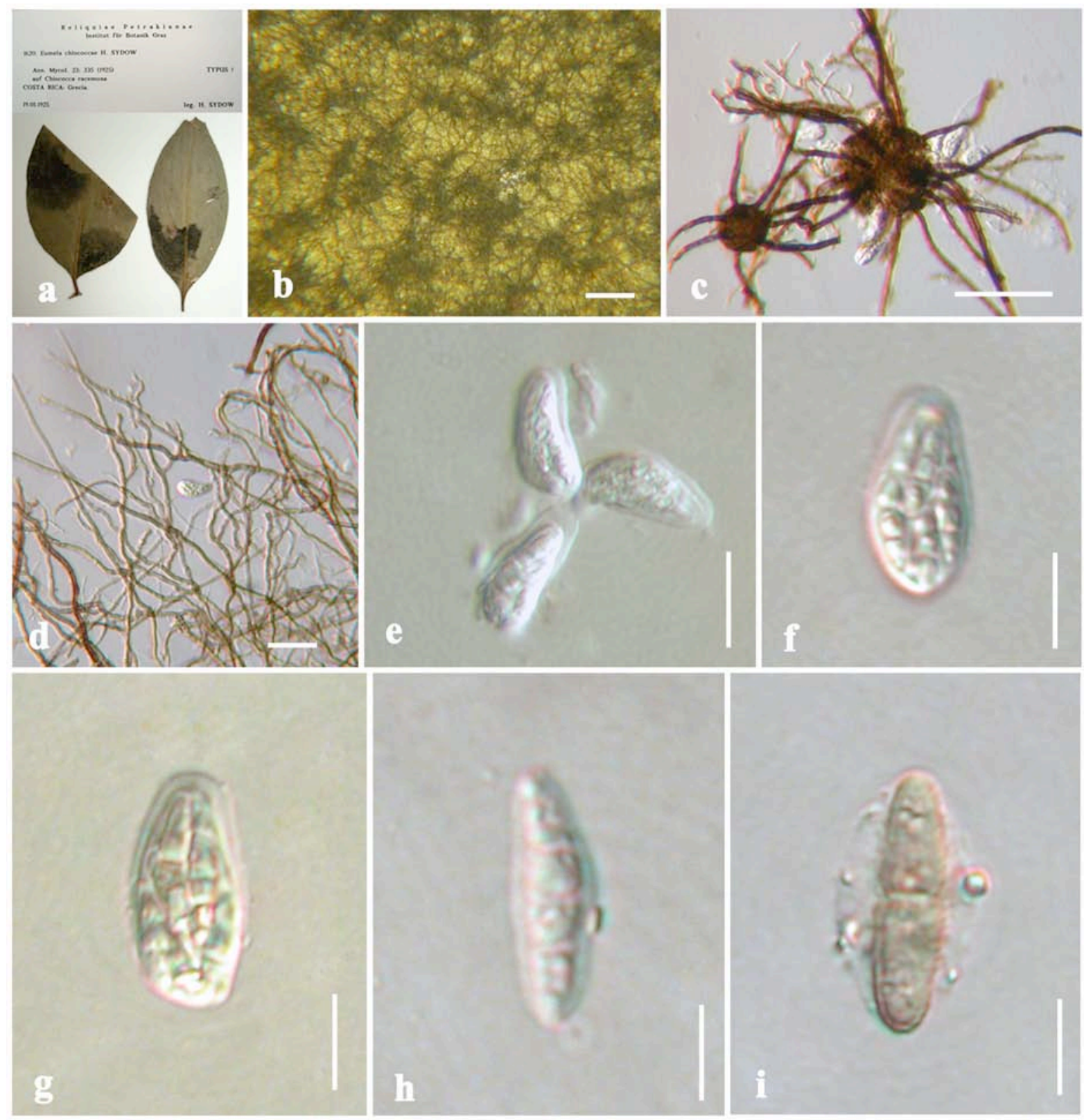

Figure 100 - Eumela chiococcae (S-F11418, holotype). a Herbarium specimen and habit on leaves. b Appearance of ascomata on leaf surface. $c$, $d$ Squash mount of ascoma, peridium and mycelia. eg Asci. h, i Ascospores. Scale bars: $\mathrm{b}-\mathrm{d}=50 \mu \mathrm{m}, \mathrm{e}-\mathrm{h}=20 \mu \mathrm{m}, \mathrm{h}-\mathrm{i}=10 \mu \mathrm{m}$. 


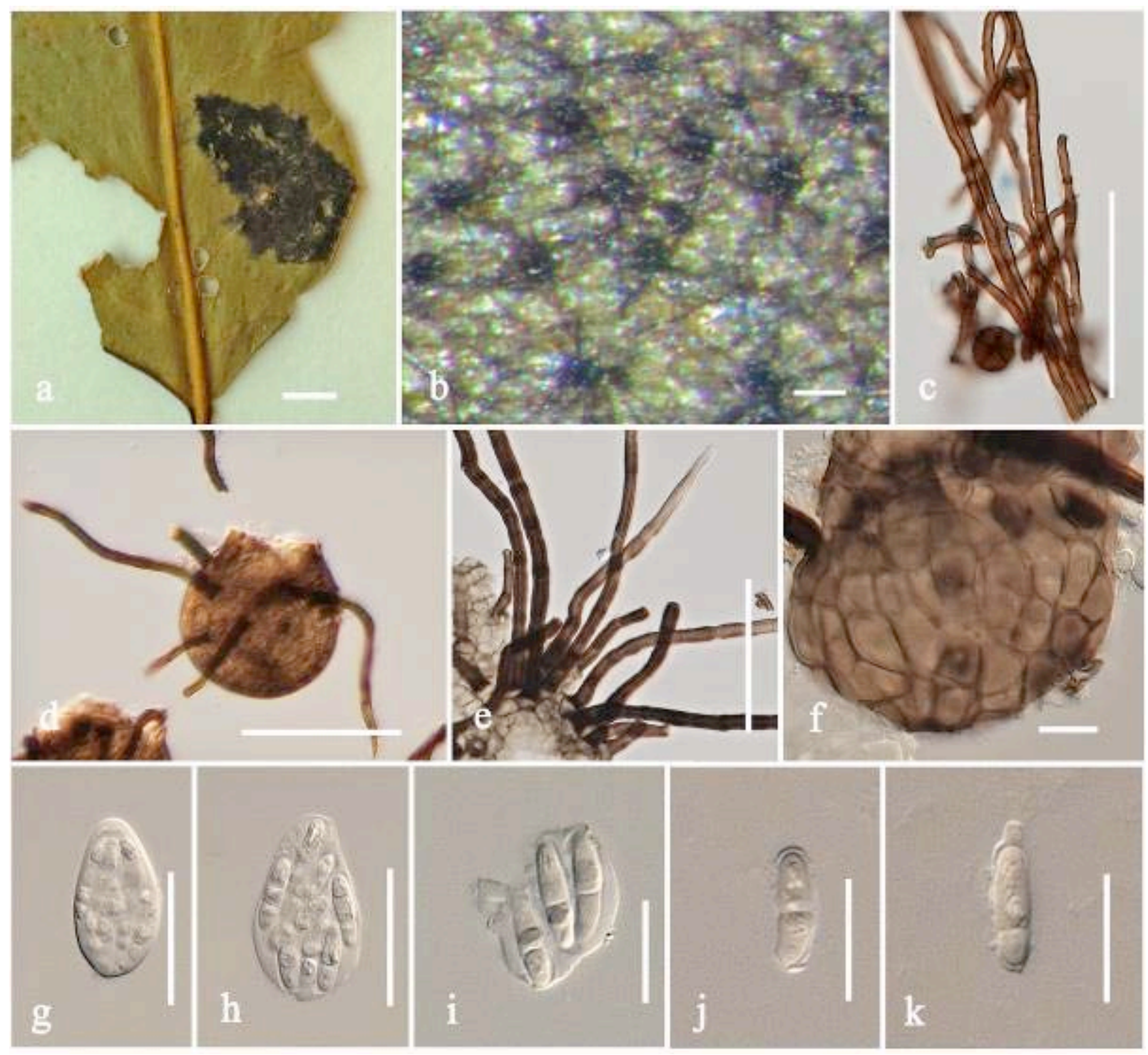

Figure 101 - Eumela chiococcae (BPI 626994, isotype). a Herbarium specimen and habit on leaf. b Appearance of ascomata. c-f Squash mount of ascoma, mycelia and peridium. g, h Asci. i-k Ascospores. Scale bars: $\mathrm{b}-\mathrm{e}=50 \mu \mathrm{m}, \mathrm{f}, \mathrm{i}-\mathrm{k}=10 \mu \mathrm{m}, \mathrm{g}-\mathrm{h}=20 \mu \mathrm{m}$.

Leptomeliola hyalospora (Lév.) Höhn., Sber. Akad. Wiss. Wien, Math.-naturw. K1., Abt. 1 128: 558 (1919)

三 Meliola hyalospora Lév., Annls Sci. Nat., Bot., sér. 3 5: 256 (1846)

= Meliolinopsis hyalospora (Lév.) Beeli, Bull. Jard. bot. État Brux. 7: 119 (1920)

Index Fungorum number: IF431759; Facesoffungi number: FoF03714 Figs 102, 103 Parasitic on living leaves of Desmoncus sp. Colonies $2.5-5 \mathrm{~mm}$ diameter, superficial, with radiating mycelium, branched, septate, dark brown, numerous with hyphopodia, 15-22 $\mu \mathrm{m}$ diameter, setae more than $200 \mu \mathrm{m}$ long $\times 7-8 \mu \mathrm{m}$ wide, tapering towards narrow apex, obtuse at the apex, slightly curved, septate, dark brown. The ascomata, asci and ascospores are absent on the type material. The description of M. hyalospora on living leaves of Desmonchi sp., Kegel, No. 594 by Léveillé (1846) is as follows: Sexual morph: Colonies superficial, orbicular, effuse, outwardly radiating mycelium, branched, hyphopodia, with erect setae. Ascomata superficial, subglobose, papillate. Asci 8-spored. Ascospores somewhat small, oval ellipsoid, 4-celled, transparent, colourless (Note asci not mentioned as bi- or uni-tunicate). Asexual morph: Undetermined.

Material examined - SURINAME, on living leaves of Desmonchi (Desmonchus = Desmoncus sp.) (Arecaceae), date not mentioned, M. Kegel 594 (ILL6481, isotype). 


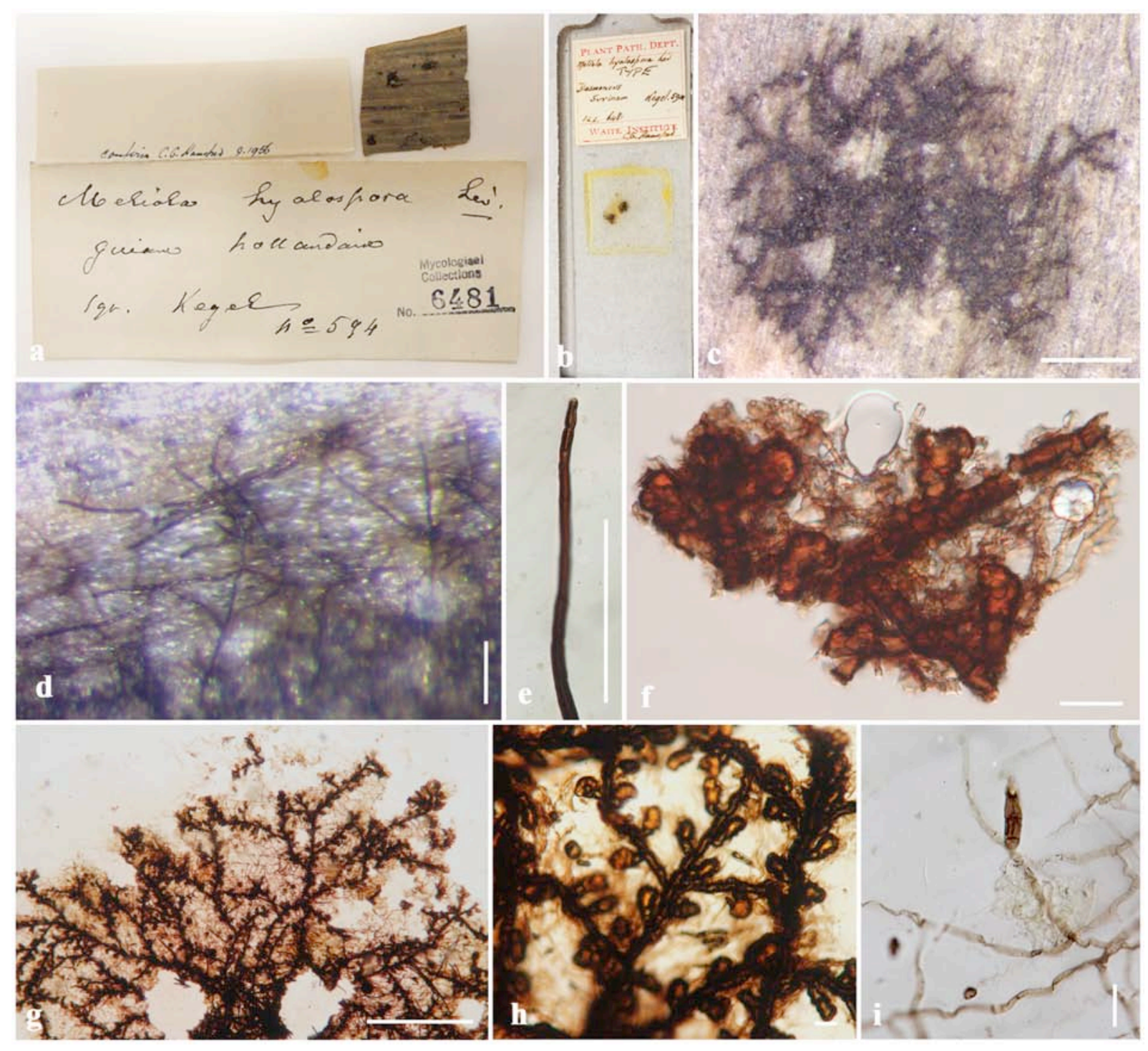

Figure 102 - Leptomeliola hyalospora (ILL6481, isotype). a Herbarium specimen and habit on leaf. b Slide samples. c Appearance of colony on leaf surface. d, e Close up of seta. $\mathrm{f}-\mathrm{h}$ Squash mount of fungal colonies with hyphopodia. i Germinated spore. Scale bars: $\mathrm{c}, \mathrm{g}=500 \mu \mathrm{m}$, d, e = $100 \mu \mathrm{m}, \mathrm{f}, \mathrm{h}, \mathrm{i}=20 \mu \mathrm{m}$.

\section{Leveillina Theiss. \& Syd. 1915}

Epifoliar on surface of leaves. Sexual morph: Ascomata solitary, erumpent, subglobose or subconical, with 2-3 locules, shiny, wrinkled, black. Asci bitunicate, clavate. Ascospores ellipsoid, 1-septate, constricted at the septum, brown (in Kalchbrenner \& Cooke 1880). Asexual morph: Conidiomata superficial or semi-immersed on surface of leaves, same as sexual morph. Peridium thick at the upper part, comprising dark brown cells of textura angularis. Conidiogenous cells phialidic, cylindrical, hyaline. Conidia globose to subglobose, 1-celled, hyaline.

Type species - Leveillina arduinae (Kalchbr. \& Cooke) Theiss. \& Syd.

Notes - The genus was established by Theiss and Sydow (1915), with type species Leveillina arduinae (三Dothidea arduinae Kalchbr. \& Cooke). Only three species are listed in Leveillina in Index fungorum (2017). The placement of this genus is uncertain (Lumbsch \& Huhndorf 2007, 2010). It is placed as Dothideomycetes genera, incertae sedis in Wijayawardene et al. (2014). 


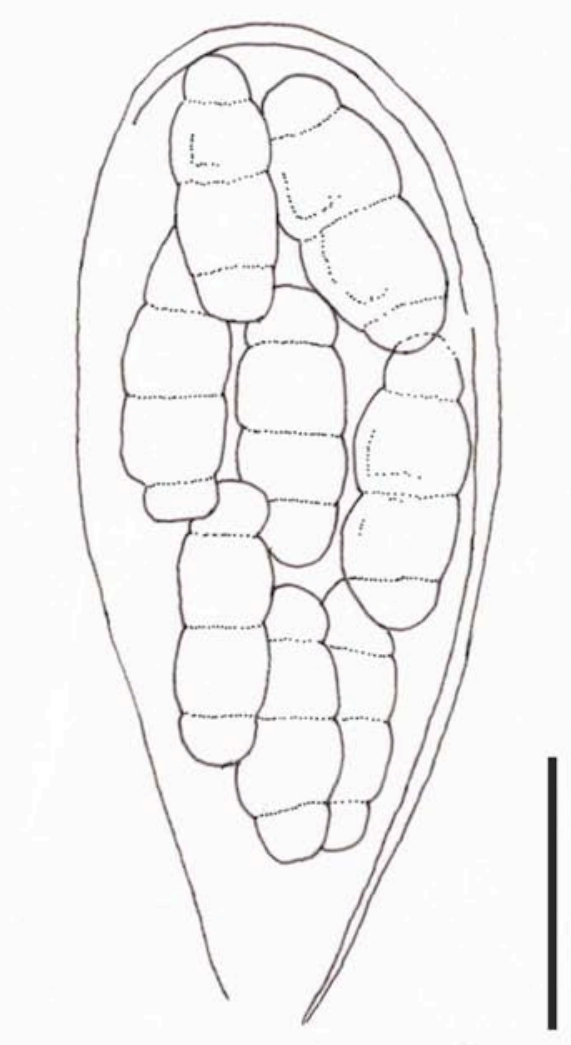

a b
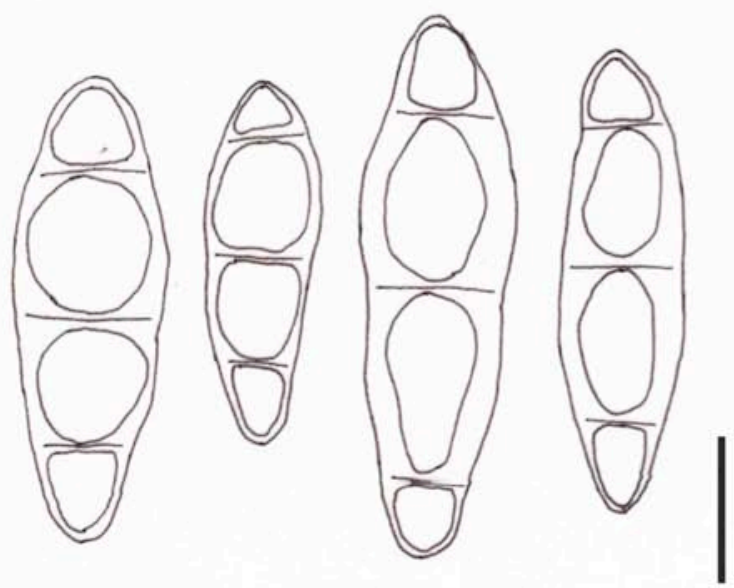

d

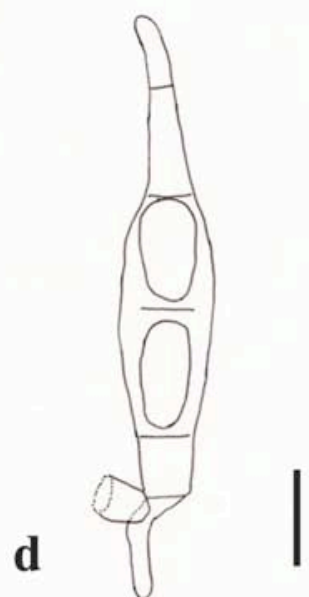

Figure 103 - Leptomeliola hyalospora. a Ascus (redrawn from Léveillé 1846). b Ascospores. c Germinated ascospores of L. hyalospora bearing collarettes. d Germinated conidia of Spiropes helleri bearing collarettes, some with phialoconidia. Note Figs $\mathrm{b}-\mathrm{d}$ are redrawn from Hughes (1993). Scale bars: $a=20 \mu \mathrm{m}, \mathrm{b}-\mathrm{d}=10 \mu \mathrm{m}$.

Leveillina arduinae (Kalchbr. \& Cooke) Theiss. \& Syd., Annls mycol. 13(3/4): 286 (1915)

Index Fungorum number: IF157931; Facesoffungi number: FoF03715

Fig. 104

Epifoliar on surface of leaves of Carissa arduino Lam. Sexual morph: Ascomata solitary, erumpent, subglobose or subconical, with 2-3 locules, shiny, wrinkled, black. Asci bitunicate, clavate. Ascospores ellipsoid, 1-septate, constricted at the septum, brown (in Grevillea 1880). Asexual morph: Conidiomata 260-370 $\mu \mathrm{m}$ diameter $\times 260-147$ high, superficial or semi-immersed on the surface of leaves, same as sexual morph. Peridium 16-25 $\mu \mathrm{m}$, thick at the upper part, comprising dark brown cells of textura angularis. Conidiogenous cells $3-4.5 \times 2-3 \mu \mathrm{m}(\bar{x}=4 \times 3$ $\mu \mathrm{m}, \mathrm{n}=10)$, phialidic, cylindrical, hyaline. Conidia 5-7 $\times 4.5-6 \mu \mathrm{m}(\bar{x}=6 \times 5 \mu \mathrm{m}, \mathrm{n}=20)$, globose to subglobose, 1-celled, hyaline, outer layer seen in cotton blue regent.

Material examined - SOUTH AFRICA, Blouberg, on leaves of Carissa arduino Lam. (Apocynaceae), Febuary 1878, McOwan 1354 (S-F68798, holotype).

Phaeostigme Syd. \& P. Syd., Annls mycol. 15(3/4): 199 (1917)

Saprobic on upper surface of dried leaves. Sexual morph: Ascomata superficial, globose to subglobose, grouped, dark brown, glabrous, with exposed ostiole. Peridium comprising 3-4 layers of dark brown cells of textura angularis. Hamathecium expanded among asci, comprising branched, septate, hyaline, pseudoparaphyses. Asci 8-spored, bitunicate, cylindric-subclavate, sessile, apically thickened, slightly narrow-obovoid, with small ocular chamber. Ascospores 2- 
seriate, obovoid, slightly fusiform-ellipsoid, 1-septate, constricted at the septum, hyaline, becoming brownish to brown at maturity, surrounded by thin gelatinous sheath, smooth-walled. Asexual morph: Undetermined.

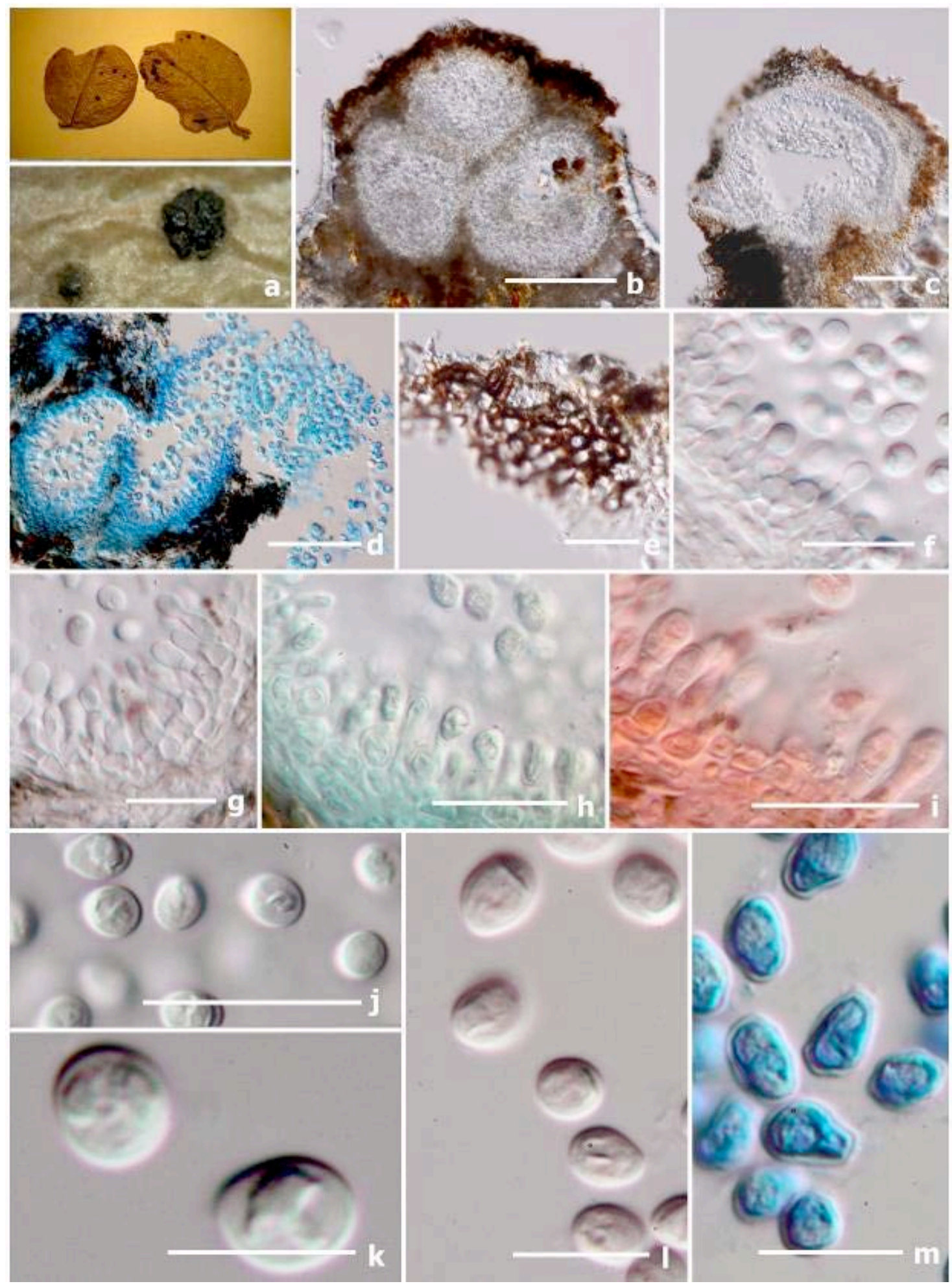

Figure 104 - Leveillina arduinae (S-F68798, holotype). a Herbarium specimen, habit on leaves and appearance of conidiomata. b, c Sections of conidiomata and peridium. $d$ Section of conidioma stained in cotton blue. e Peridium. f-i Conidiogenous cells stained by cotton blue and congo red. $\mathrm{j}$ $\mathrm{m}$ Conidia stained by congo red and cotton blue. Scale bars: $\mathrm{b}=100 \mu \mathrm{m}, \mathrm{c}, \mathrm{d}=50 \mu \mathrm{m}, \mathrm{e}-\mathrm{j}, \mathrm{l}, \mathrm{m}=$ $20 \mu \mathrm{m}, \mathrm{k}=10 \mu \mathrm{m}$. 
Type species - Phaeostigme picea (Berk. \& M.A. Curtis) Syd. \& P. Syd.

Notes - Sydow \& Sydow (1917) introduced Phaeostigme which is typified by P. picea (三 Asterina picea Berk. \& M.A. Curtis) and is synonymised under Dimerium piceum Berk. \& M.A. Curtis) Theiss. We re-examined the type specimen of $P$. picea (as Asterina picea) from Kew collection under no. K(M): 38642 and specimen was in poor in condition. We therefore loaned a collection from BPI. The genus is characterized by mycoparasitic, superficial, glabrous ascomata, growing on mycelium of Meliola colonies. Phaeostigme picea was distinguished from species in Asterina and Dimerium by its ascomata features and lack of superficial mycelium and hyphopodia. Lumbsch \& Huhndorf (2010) listed Phaeostigme in Pseudoperisporiaceae. Phaeostigme can be distinguished from genera in Pseudoperisporiaceae by its ascomata with pigmented colonies and lack of superficial mycelium. The genus is therefore treated in Dothideomycetes genera, incertae sedis.

Phaeostigme alchorneae Boonmee \& K.D. Hyde, sp. nov.

Index Fungorum number: IF553839; Facesoffungi number: FoF03716

Fig. 105

Etymology - Referring to the host plant Alchornea cordifolia

Mycoparasitic, fungicolous on dark colonies of Irenina sp. (Meliolaceae), on living leaves of Alchornea cordifolia Müll. Arg. Sexual morph: Ascomata 152-163 $\mu \mathrm{m}$ diameter, superficial, solitary, scattered in black colonies, globose to subglobose, dark brown to black, glabrous, with apical ostiole, collapsing when dry, surrounded by dark brown mycelia. Peridium 14.5-17 $\mu \mathrm{m}$ wide, comprising 3-4 layers of dark brown cells of textura angularis. Hamathecium $1-2.5(-3) \mu \mathrm{m}$ wide, expanded among asci, comprising branched, septate, hyaline, pseudoparaphyses. Asci 40$56(-60) \times 9-11 \mu \mathrm{m}(\bar{x}=46 \times 10 \mu \mathrm{m}, \mathrm{n}=20), 8$-spored, bitunicate, cylindric-subclavate, sessile, apically thickened, slightly narrow-obovoid, with small ocular chamber. Ascospores 12-16 $\times$ 5-6 $\mu \mathrm{m}(\bar{x}=14 \times 6 \mu \mathrm{m}, \mathrm{n}=20), 2$-seriate, obovoid, slightly fusiform-ellipsoid, 1-septate, constricted at the septum, hyaline, becoming brownish to brown at maturity, surrounded by thin gelatinous sheath, smooth-walled. Asexual morph: Undetermined.

Material examined - UGANDA, Kawanda, on dark colonies of Irenina sp. (Meliolaceae), on living leaves of Alchornea cordifolia Müll. Arg. (Euphorbiaceae), August 1940, C.G. Hansford (BPI 691253, holotype).

Notes - Phaeostigme alchorneae shares morphological features with the type species P. picea in having superficial, pigmented ascomata, cylindric-subclavate, bitunicate asci and fusiformellipsoid, 1-septate, hyaline to pigmented ascospores (Sydow \& Sydow 1917, Batista \& Maia 1960a). However, P. alchorneae differs from the type species $P$. picea by its black colonies and scattered ascomata and based on morphology, P. alchorneae may not belong in Phaeostigme.

Phaeostigme picea (Berk. \& M.A. Curtis) Syd. \& P. Syd., Annls mycol. 15(3/4): 200 (1917)

$\equiv$ Asterina picea Berk. \& M.A. Curtis, J. Linn. Soc., Bot. 10(no. 46): 374 (1868)

$\equiv$ Dimerium piceum (Berk. \& M.A. Curtis) Theiss., Annls mycol. 10(1): 3 (1912)

Index Fungorum number: IF102485; Facesoffungi number: FoF03244

Fig. 106

Saprobic on upper surface of dried leaves. Ascomata 93-102 $\mu \mathrm{m}$ diameter, superficial, globose to subglobose, grouped, dark brown, with exposed ostiole, peridium comprising dark brown cells of textura angularis, asci and ascospores absent. Sydow and Sydow (1917) described fungus with clavate asci and narrow oblong, 1-septate ascospores. Notes: The holotype specimen $(\mathrm{K}(\mathrm{M}): 38642)$ is in poor condition, all ascomata are deteriorated and lack asci, ascospores and other sterile tissues.

Material examined - CUBA, on upper surface of dried leaves (unidentified host), date undetermined, C. Wright 144 (ex herb. M. J. Berkeley), (K(M): 38642, holotype). 

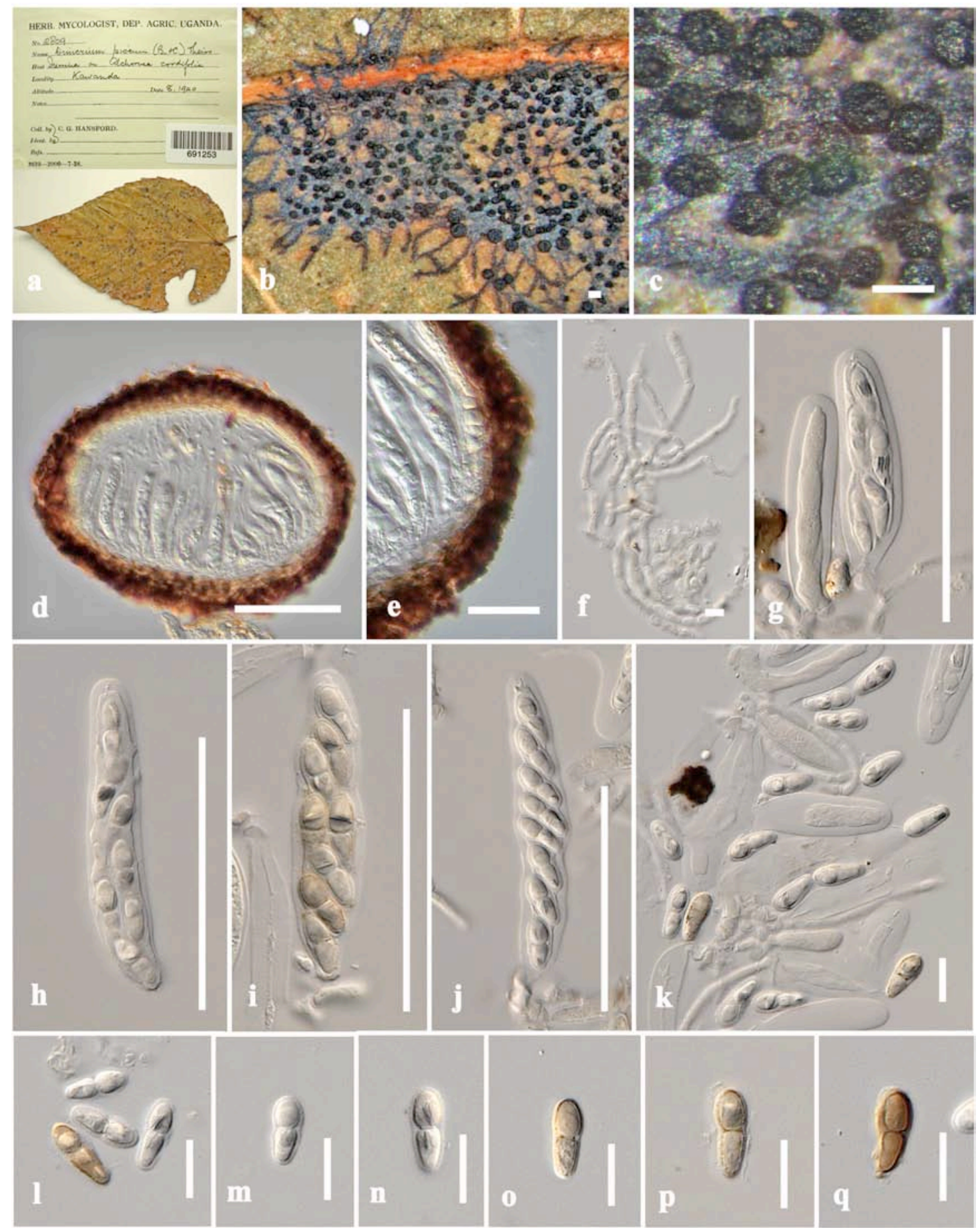

Figure 105 - Phaeostigme alchorneae (BPI 691253, holotype). a Herbarium specimen and habit on leaf. $b$, c Appearance of ascomata on leaf surface. d Section of ascoma. e Peridium. $f$ Pseudoparaphyses. $\mathrm{h}-\mathrm{j}$ Asci. $\mathrm{k}-\mathrm{q}$ Ascospores at immature and mature states. Scale bars: $\mathrm{b}, \mathrm{c}=100$ $\mu \mathrm{m}, \mathrm{d}, \mathrm{g}-\mathrm{j}=50 \mu \mathrm{m}, \mathrm{e}=20 \mu \mathrm{m}, \mathrm{f}=5 \mu \mathrm{m}, \mathrm{k}-\mathrm{q}=10 \mu \mathrm{m}$.

Scolionema Theiss. \& Syd., Annls mycol. 15(6): 410 (1918) [1917]

Parasitic on living leaves. Sexual morph: Colonies up to $5 \mathrm{~mm}$ diameter, subcircular to irregular, superficial hyphae erect, dense, radiating outwards, flexuous, unbranched, septate, dark brown. Ascomata superficial, gregarious or solitary, seated on a subiculum, subglobose, carbonaceous and slightly brittle, black, with apical ostiole, covered by dark brown hyphae. Peridium exceeding $100 \mu \mathrm{m}$ diameter, comprising dark brown to black cells of textura angularis and mixed with carbonaceous matter. Ascomata subglobose, sparse pseudoparaphyses, flexuous, filiform and hyaline. Asci 8 -spored, bitunicate, subglobose to broadly obovoid, short pedicellate. 
Ascospores 3-4-seriate, conglobate, broadly ellipsoidal to sub-fusiform, with upper cell slightly wider than the lower, 1-septate, constricted at the septum, hyaline, smooth-walled. Asexual morph: Undetermined.

Type species - Scolionema palmarum (Kunze \& Fr.) Theiss. \& Syd.

Notes - The genus Scolionema was described and introduced by Theissen \& Sydow (1917) based on S. palmarum and it has remained monotypic. It has been placed in Polystomellaceae based on ascomata characters. This genus has been moved to several genera and families based on various characters (Fries 1829, Gaillard 1892, Hansford 1946, Petrak 1959, Müller \& von Arx 1962, von Arx \& Müller 1975). Eriksson et al. (2001) included Scolionema in Parodiopsidaceae (currently named Perisporiopsidaceae). The type species $S$. palmarum is characterised by dark colonies, with dense superficial hyphae, ascomata occurring among the dense dark hyphae, bitunicate asci and 1septate, hyaline ascospores. Based on this morphology, Scolionema can be distinguished from all genera in Pseudoperisporiaceae. Therefore, we treat Scolionema as a genus in Dothideomycetes genera, incertae sedis.
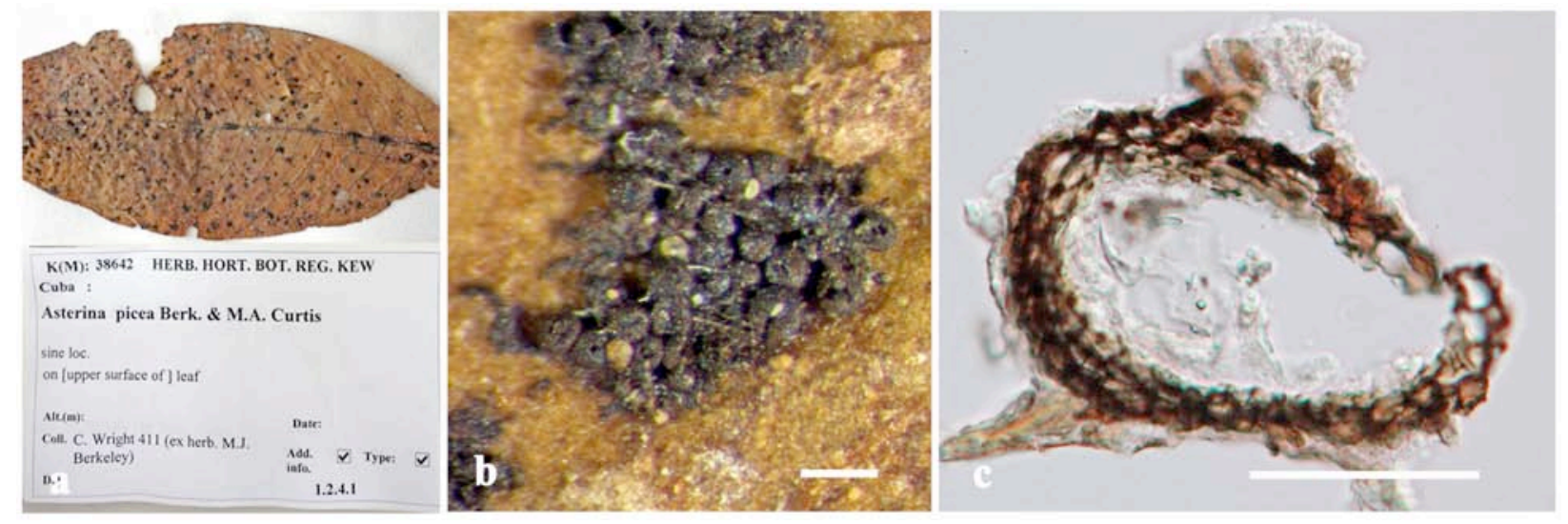

Figure 106 - Phaeostigme picea (K(M): 38642, holotype). a Herbarium specimen and habit on leaf. $\mathrm{b}$ Appearance of ascomata on leaf surface. $\mathrm{c}$ Section of ascoma. Scale bars: $\mathrm{b}=200 \mu \mathrm{m}, \mathrm{c}=$ $50 \mu \mathrm{m}$.

Scolionema palmarum (Kunze \& Fr.) Theiss. \& Syd., Annls mycol. 15(6): 410 (1918) [1917]

$\equiv$ Myxothecium palmarum Kunze \& Fr., Syst. mycol. (Lundae) 3(1): 232 (1829)

$\equiv$ Meliola palmarum (Kunze \& Fr.) Sacc., Syll. fung. (Abellini) 1: 71 (1882)

$\equiv$ Asterina palmarum (Kunze \& Fr.) Gaillard, Bull. Soc. mycol. Fr. 8(3): 116 (1892)

$\equiv$ Myxotheciella palmarum (Kunze \& Fr.) Petr., Sydowia 13(1-6): 40 (1959)

Index Fungorum number: IF175370; Facesoffungi number: FoF03718

Fig. 107

Parasitic on living leaves of Cocos sp. Sexual morph: Colonies up to $5 \mathrm{~mm}$ diameter, subcircular to irregularly, superficial hyphae erect, dense, radiating outwardly flexuous, unbranched, septate, dark brown. Ascomata 180-260 $\mu \mathrm{m}$ diameter, superficial, gregarious or solitary, seated on a subiculum, subglobose, carbonaceous and slightly brittle, black, with apical ostiole, covered by dark brown hyphae. Peridium exceeding $100 \mu \mathrm{m}$ diameter, comprising dark brown to black cells of textura angularis and mixed with carbonaceous matter. Asci $130 \times 60 \mu \mathrm{m}$, 8-spored, bitunicate, subglobose to broadly obovoid, short pedicellate. Ascospores 65-75 $\mu \mathrm{m} \times 20$ $22 \mu \mathrm{m}, 3-4$-seriate, conglobate, broadly ellipsoidal to sub-fusiform, with the upper cell slightly wider, 1-septate, constricted at the septum, hyaline, smooth-walled. The structures of the pseudoparaphyses, asci, ascospores and other microscopic structures could not be determined from the type material, therefore, illustrations and detailed descriptions to represent the genus are used following Gaillard (1892). Asexual morph: Undetermined.

Material examined - SURINAME, on living leaves of Cocos sp. (Arecaceae), 1827, C. Weigelt (MICH14659, isotype). 


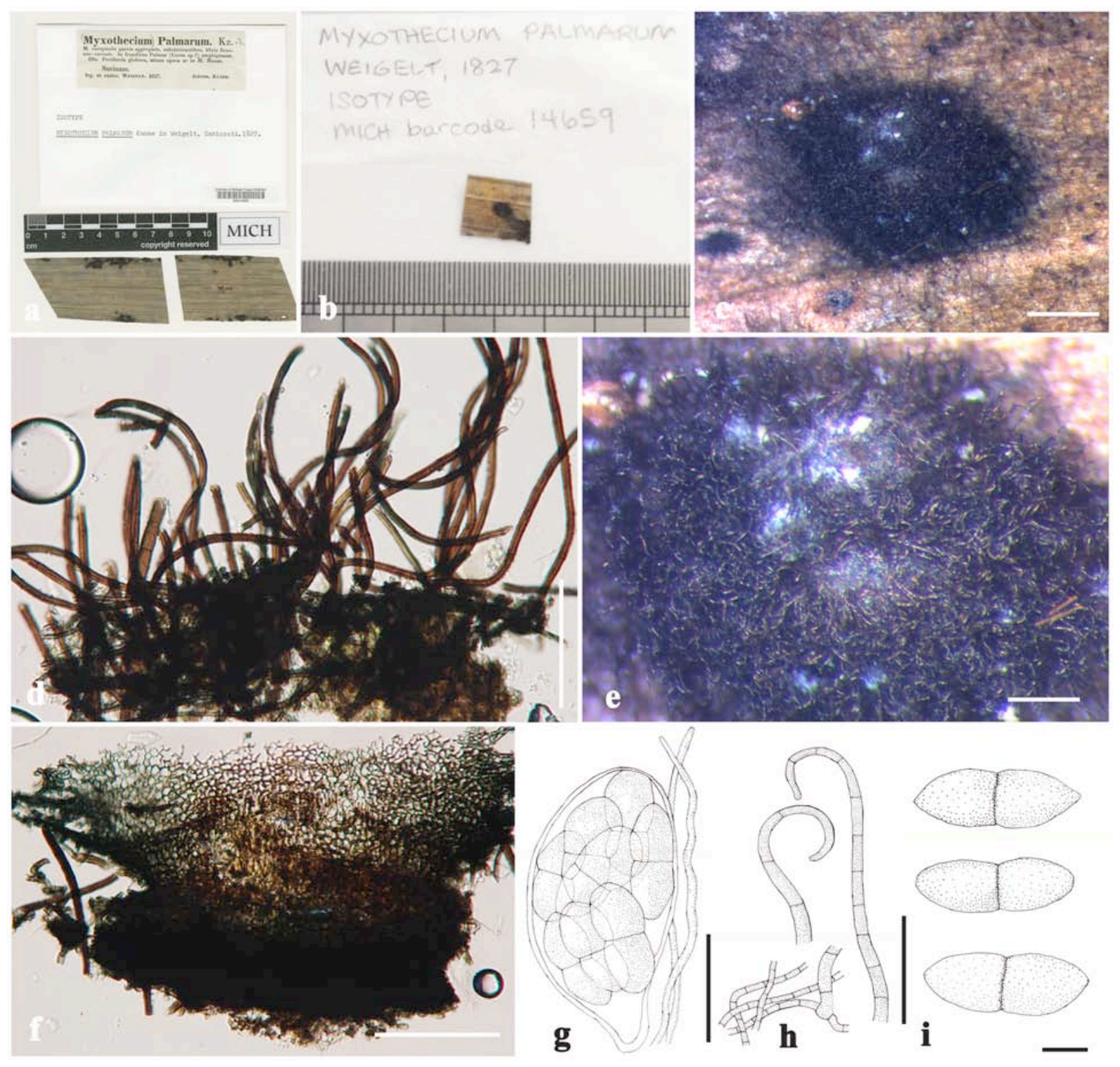

Figure 107 - Scolionema palmarum (MICH 14695, isotype). a, b Herbarium specimen and habit on leaves. c Appearance of colony and ascomata on leaf surface. d Superficial mycelium. e Close up of ascomata among dense mycelium. f Section of ascoma. g Asci. h Mycelium i Ascospores. (Figs g-i redrawn from Asterina palmarum, Gaillard 1892). Scale bars: $\mathrm{c}=500 \mu \mathrm{m}, \mathrm{d}, \mathrm{h}=100 \mu \mathrm{m}$, $\mathrm{e}=200 \mu \mathrm{m}, \mathrm{f}, \mathrm{g}=50 \mu \mathrm{m}, \mathrm{i}=20 \mu \mathrm{m}$.

\section{Pleoporales genera, incertae sedis}

Based on ascomata features, the genus Stuartella is treated as genera incertae sedis in Pleoporales.

Stuartella Fabre, Annls Sci. Nat., Bot., sér. 6 9: 95 (1879) [1878]

Parasitic or saprobic on dead wood. Sexual morph: Ascomata superficial to erumpent on wood, slightly gregarious, subglobose to globose. Peridium comprising 2 layers of dark brown to black cells of textura angularis, top view of ascomata cells showing textura porrecta. Hamathecium comprising branched, aseptate, anastomosed, pseudoparaphyses. Asci 8-spored, bitunicate, cylindrical or obovoid, lacking or with very short rounded pedicel, ocular chamber present when immature. Ascospores overlapping, 2-3-seriate, ellipsoid to fusiform, 1-septate at the center when immature, 3-septate at maturity, constricted and darker at the septa, with narrow end 
cells, hyaline to pale brown when immature, brown to dark brown at maturity, smooth-walled, sometimes with mucous at maturity. Asexual morph: Undetermined.

Type species - Stuartella formosa Fabre

Notes - Stuartella was established by Fabre (1879), with S. formosa as the type species. Later, five species were introduced (Index Fungorum 2017). Although Stuartella was placed in Sphaeriaceae (Rehm 1899), the placement of Stuartella is uncertain because it has been poorly studied. Stuartella formosa (type species) was placed with Enchnosphaeria pinetorum Fuckel, Melanommataceae (Höhnel 1913). Trematosphaeria irregularis Fabre was considered as a synonym of $S$. formosa by Berlese (1894), however, the original specimen of $T$. irregularis showed the differences of ascospores (Müller 1962). Stuartella was treated as Dothideomycetes genera, incertae sedis (Wijayawardene et al. 2014, Index Fungorum 2017). We are unable to locate the type specimen of $S$. formosa and no sequence data is available. Therefore, we illustrate and described a specimen of Stuartella drimydis (S-F51087) to represent Stuartella. Although, the ascomata with longitudinal ostiole was found in $S$. drimydis, however, this genus cannot be placed in Hysteriales based on non-hysteriaceous ascomata. We therefore treat the Stuartella as genera incertae sedis in Pleoporales based on ascomata and ascospores charecters of $S$. drimydis (observed in this paper) and S. formosa (Müller 1962).

Stuartella drimydis Rehm [as 'drymidis'], Bih. K. svenska Vetensk-Akad. Handl., Afd. 3 25(no. 6): 5 (1899)

Index Fungorum number: IF244518; Facesoffungi number: FoF03719

Fig. 108

Parasitic or saprobic on dead wood. Sexual morph: Ascomata 344-375 $\mu \mathrm{m}$ diameter $\times 276$ $300 \mu \mathrm{m}$ high, superficial to erumpent on upper surface of wood, slightly gregarious, subglobose to globose, sometimes with longitudinal ostiole. Peridium comprising 2 layers of dark brown to black cells of textura angularis, top view of ascomata cells showing textura porrecta. Hamathecium 2 $\mu \mathrm{m}$ wide, comprising branched, aseptate, anastomosed, pseudoparaphyses. Asci 166-175 × 54-60 $\mu \mathrm{m}(\bar{x}=172 \times 57 \mu \mathrm{m}, \mathrm{n}=5), 8$-spored, bitunicate, cylindrical or obovoid, lacking or with very short rounded pedicel, ocular chamber present when immature. Ascospores 61-64 × 21-25 $\mu \mathrm{m}$ diameter $(\bar{x}=62 \times 22 \mu \mathrm{m}, \mathrm{n}=10)$, overlapping 2-3-seriate, ellipsoid to fusiform, 1-septate at the center when immature, 3 -septate at maturity, constricted and darker at the septa, end cells narrow, hyaline to pale brown when immature, brown to dark brown at maturity, smooth-walled, sometimes with mucous at maturity. Asexual morph: Undetermined.

Material examined - CHILE, Desolación Island, on dead wood, date undetermined, P. Dusén (S-F51087).

\section{Eurotiomycetes O.E. Erikss. \& Winka Chaetothyriales M.E. Barr}

\section{Epibryaceae S. Stenroos \& Gueidan}

The family Epibryaceae was established by Gueidan et al. (2014) in Chaetothyriales, Eurotiomycetes, and includes the taxa Epibryon, Cladophialophora and one species Leptomeliola ptilidii (Stenroos et al. 2010, Gueidan et al. 2014). The family includes mostly biotrophic parasites of foliose hepatics and mosses including Sphagnum and Polytrichaceae. Some melanised asexual taxa, isolated from rock surfaces or from soil or associated with vascular plants are also included (Gueidan et al. 2014, Muggia et al. 2015, 2016, Teixeira et al. 2017). Their ascomata are pale to dark brown to black with straight or curved dark setae. Asci are ovoid, ellipsoidal or subcylindrical, without apical structures. Ascospores are transversely septate, and ellipsoidal to fusiform (Döbbeler 1997, Gueidan et al. 2014).

Family type - Epibryon Döbbeler 


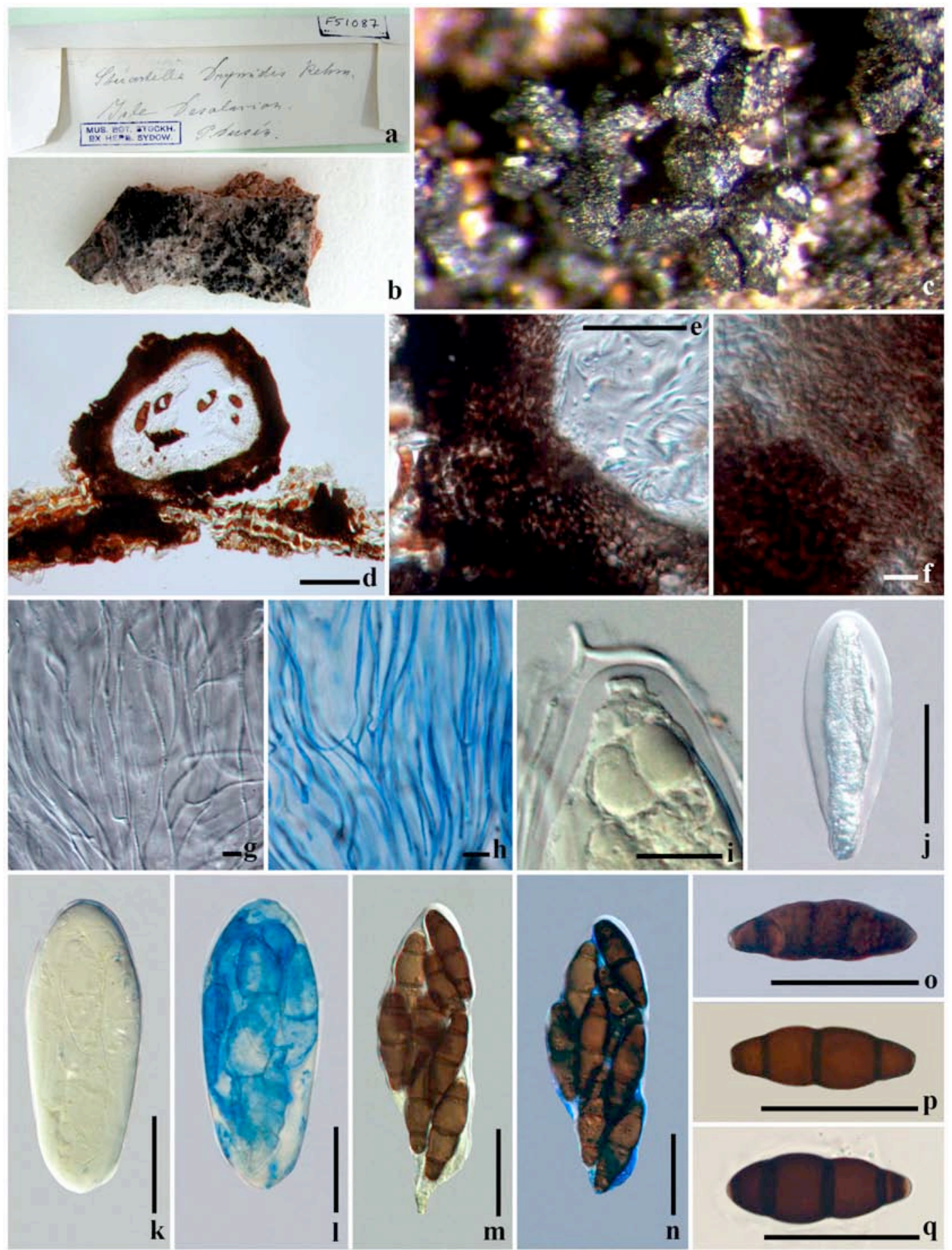

Figure 108 - Stuartella drimydis (S-F51087). a, b Herbarium specimen and habit on wood. c Appearance of ascomata on wood. d Section of ascoma. e Peridium. $f$ Upper wall of ascoma. $g, h$ Hamathecium stained in cotton blue reagent. i Ocular chamber. j-1 Young ascus stained in Melzer's and cotton blue reagent. $\mathrm{m}, \mathrm{n}$ Mature ascus stained in Melzer's and cotton blue reagent. o, $\mathrm{p}$ Ascospores stained in cotton blue and Melzer's reagent. p Ascospore in Melzer's reagent. $q$ Ascospore with mucous. Scale bars: $\mathrm{d}=100 \mu \mathrm{m}, \mathrm{e}, \mathrm{j}-\mathrm{q}=50 \mu \mathrm{m}, \mathrm{i}=20 \mu \mathrm{m}, \mathrm{f}-\mathrm{h}=10 \mu \mathrm{m}$.

Epibryon Döbbeler, Mitt. bot. StSamml., Münch. 14: 260 (1978)

Saprobic on hairy leaves. Sexual morph: Ascomata superficial, subglobose to globose, without pseudoparaphyses, covered by setae. Setae dark brown, simple, straight or curved, septate, usually arising at the upper part, slightly constricted at the septa, apex rounded, sometimes gradually tapering towards the apex. Peridium $8-11 \mu \mathrm{m}$ wide, comprising several layers of brown to dark brown cells of textura angularis. Asci 8-spored, bitunicate, ellipsoid, oblong to broadly 
obovoid, apex rounded, embedded in a gelatinous matrix. Ascospores 2-3-seriate and overlapping, hyaline to pale grey, ellipsoid-fusiform, broader median to supramedian, tapering towards the subacute ends, septum median to supramedian, not constricted at the septa, 1-septate, smoothwalled. Asexual morph: Undetermined.

Type species - Epibryon plagiochilae (Gonz. Frag.) Döbbeler

Notes - Epibryon was introduced by Döbbeler (1978) with E. plagiochilae as the type species. It was placed in Pseudoperisporiaceae families, incertae sedis (Lumbsch \& Huhndorf 2007, Hyde et al. 2013, Wijayawardene et al. 2014). Epibryon was classified in Epibryaceae, Chaetothyriales, Eurotiomycetes based on phylogenetic analyses of nuLSU, nuSSU, mtSSU and RPB1 (Gueidan et al. 2014). The species in Epibryon are mostly biotrophic parasites and some are saprobes (Döbbeler 1978). Epibryon is rather diverse with over 30 assigned species, but they share characters. Their ascomata are globose or semi-globose, usually setose at the upper part. Ascospores are two- or multi-celled, hyaline to brown, and smooth-walled and the hymenium gel stains red with Lugol's solution (Döbbeler 1978).

Epibryon plagiochilae (Gonz. Frag.) Döbbeler, Mitt. bot. StSamml., Münch. 14: 293 (1978)

$\equiv$ Coleroa casaresii var. plagiochilae Gonz. Frag. [as 'casaresi'] 1919

Index Fungorum number: IF313925; Facesoffungi number: FoF03720

Fig. 109

Saprobic on hairy leaves of Plagiochilae asplenioidis (L. em. Tayl.) Dum. Sexual morph: Ascomata (70-)76-84(-89) $\mu \mathrm{m}$ diameter $\times(73-) 77-905(-97) \mu \mathrm{m}$ high, superficial, subglobose to globose, without pseudoparaphyses, covered by dark brown setae. Setae (36.5-)42-60(-72) $\mu \mathrm{m}$ long, dark brown, simple, straight or curved, septate, usually arising at the upper part, slightly constricted at the septa, apex rounded, sometimes gradually tapering towards the apex. Peridium 8$11 \mu \mathrm{m}$ wide, comprising several layers of brown to dark brown cells of textura angularis. Asci (30)34-41.5(-42) $\times 10-13(-14) \mu \mathrm{m}(\bar{x}=36 \times 11 \mu \mathrm{m}, \mathrm{n}=20), 8$-spored, bitunicate, ellipsoid, oblong to broadly obovoid, apex rounded, embedded in a gelatinous matrix. Ascospores $13-15(-17) \times 4-$ $5.5 \mu \mathrm{m}(\bar{x}=14 \times 4.5 \mu \mathrm{m}, \mathrm{n}=20), 2-3$ seriate and overlapping, hyaline to pale grey, ellipsoidfusiform, broader median to supramedian, tapering towards the subacute ends, septum median to supramedian, not constricted at the septa, 1-septate, smooth-walled. Asexual morph: Undetermined.

Material examined - AUSTRIA, Steiermark, Grazer Bergland, Dürrbachgraben östlich GrazAndritz, reichlich, on hairy leaves of Plagiochilae asplenioidis (L. em. Tayl.) Dum. (Plagiochilaceae), July 1972, J. Poelt, Inv. Nr. 88-89 (DigiBota ID 266896, GZU 000291905).

\section{Chaetothyriales genera, incertae sedis}

Based on sequence data, the genus Pleostigma is treated as genera incertae sedis in Chaetothyriales.

Pleostigma Kirschst., Annls mycol. 37(1/2): 91 (1939)

Parasitic or saprobic on living leaves of liverworts. Sexual morph: Ascomata superficial, slightly erumpent at the base on surface of leaves, solitary, comprising thick-walled, brown-walled cells of textura angularis, peridium comprising 2 layers of hyaline to dark brown cells of textura angularis, when viewed in squash mount wall showing as textura globulosa to angularis. Hamathecium comprising aseptate, anastomosed, pseudoparaphyses. Asci 8-spored, bitunicate, broadly cylindrical or obovoid, with short, rounded pedicel, and with ocular chamber. Ascospores overlapping, uni-biseriate, ellipsoid to fusiform, 4-6-transverse septate, 1-longitudinal septate, constricted at the septa, hyaline to yellow or pale brown when immature, brown to dark brown at maturity, smooth-walled. Asexual morph: Undetermined.

Type species - Pleostigma jungermannicola (C. Massal.) Kirschst.

Notes - Pleostigma was established by Kirschstein (1939) for nine species, the type species is $P$. jungermannicola. The genus was treated as Dothideomycetes genera, incertae sedis based on its morphological uniqueness (Lumbsch \& Huhndorf 2007, Wijayawardene et al. 2014). Sequence data of P. jungermannicola placed the genus in Chaetothyriales of Eurotiomycetes (Stenroos et al. 
2010) because of unclear morphological characters between the two classes (Lumbsch and Huhndorf 2007). Fresh collections are needed to obtain molecular data which can demonstrate the correct placement of Pleostigma.

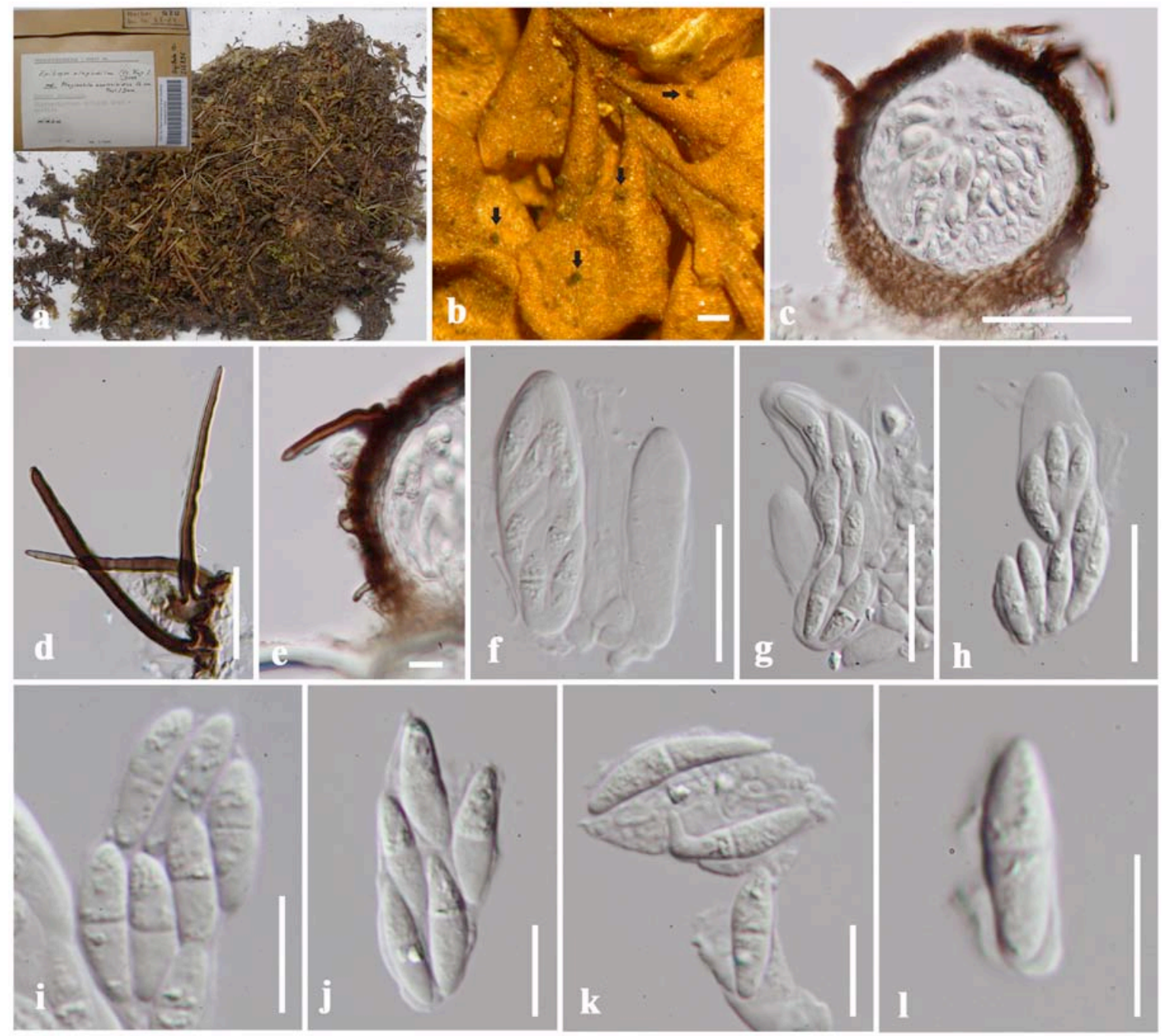

Figure 109 - Epibryon plagiochilae (GZU 000291905), a Herbarium specimen and habit on leaves. b Appearance of ascomata on leaf surface. c Section of ascoma. d Setae. e Peridium. $\mathrm{f}-\mathrm{h}$ Immature and mature asci. i-1 Ascospores. Scale bars: $b, c=50 \mu \mathrm{m}, \mathrm{d}-\mathrm{h}=20 \mu \mathrm{m}, \mathrm{i}-1=10 \mu \mathrm{m}$.

Pleostigma jungermannicola (C. Massal.) Kirschst., Annls mycol. 37(1/2): 91 (1939)

$\equiv$ Strickeria jungermannicola C. Massal., Atti dell'Acc. delle Sc. Med. e Nat. Ferrara: tab. 3 (1895)

$\equiv$ Teichospora jungermannicola (C. Massal.) Sacc. \& P. Syd., Syll. fung. (Abellini) 14(1): 606 (1899)

= Pleospora hepaticicola Walt. Watson [as 'hepaticola'], Trans. Br. mycol. Soc. 4(2): 295 (1914) [1913]

Index Fungorum number: IF268477; Facesoffungi number: FoF03721

Fig. 110

Parasitic or saprobic on living leaves of Lophocolea minor Nees. Sexual morph: Ascomata 147-219 $\mu \mathrm{m}$ diameter $\times 160-199 \mu \mathrm{m}$ high, superficial, slightly erumpent at the base, on surface of liverworts, solitary, comprising thick-walled, brown-walled cells of textura angularis, peridium comprising 2 layers of hyaline to dark brown cells of textura angularis, when viewed in squash mount wall showing as textura globulosa to angularis. Hamathecium $1 \mu \mathrm{m}$, comprising aseptate, pseudoparaphyses, anastomosing between and above the asci. Asci $61-70 \times 28-34 \mu \mathrm{m}(\bar{x}=67 \times$ $30 \mu \mathrm{m}, \mathrm{n}=10$ ), 8-spored, bitunicate, broadly cylindrical or obovoid, with short, rounded pedicel, 
and with ocular chamber. Ascospores 25-27 $\times 10-12 \mu \mathrm{m}(\bar{x}=25.5 \times 11 \mu \mathrm{m}, \mathrm{n}=10)$, overlapping, uni-biseriate, ellipsoid to fusiform, with 4-6 transverse septa and 1 longitudinal septa, constricted at the septa, hyaline to yellow or pale brown when immature, brown to dark brown at maturity, smooth-walled. Asexual morph: Undetermined.

Material examined - CANADA, Eastern Canada, Nashville, York, Ontario, on living leaves of Lophocolea minor Nees (Lophocoleaceae), 7 May 1955, R.F. Cain (IMI 73319).

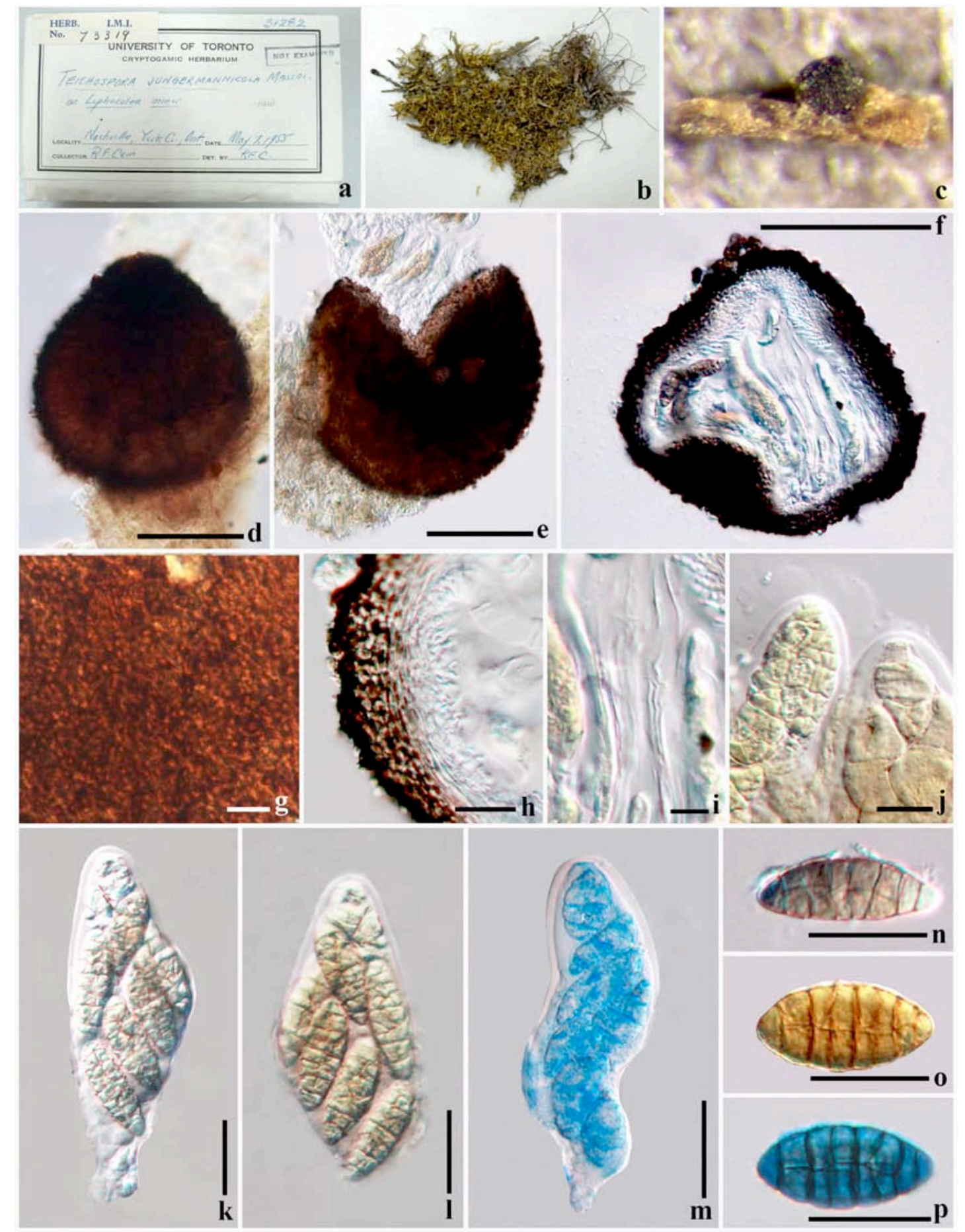

Figure 110 - Pleostigma jungermannicola (IMI 73319). a, b Herbarium specimens and habit on leaves. c Appearance of ascoma on leaf surface. d, e Squash mount of ascomata. $f$ Section of ascoma. g Upper wall cells. h Peridium. i Hamathecium. j Ocular chamber. $\mathrm{k}-\mathrm{m}$ Immature and mature asci stained in cotton blue and Melzer's reagent. $\mathrm{n}$ Ascospores stained in Melzer's and cotton blue reagent. Scale bars: $d-f=100 \mu \mathrm{m}, \mathrm{g}, \mathrm{i}, \mathrm{j}=10 \mu \mathrm{m}, \mathrm{h}, \mathrm{k}-\mathrm{p}=20 \mu \mathrm{m}$. 


\section{Excluded genera}

\section{Sordariomycetes genera, incertae sedis}

Based on ascus features to be unitunicate, the genus Phragmeriella is treated as genera incertae sedis in Sordariomycetes.

Phragmeriella Hansf., Mycol. Pap. 15: 89 (1946)

Parasitic or hyperparasitic, fungicolous on mycelium of Irenina tremae Speg. (Meliolaceae), superficial mycelium, branched and coloured. Sexual morph: Ascomata superficial, grouped, globose to subglobose, seated on mycelium of another fungus, transparent to light brown, texture soft, surrounded by colourless setae, aseptate, collapsing when dry. Peridium comprising 1-2 layers of light brown cells of textura angularis, lacking pseudoparaphyses. Asci 8-spored, unitunicate, oblong-subclavate, sessile, apex flattened. Ascospores 1-2-seriate, ellipsoid to obovate-oblong, ends rounded, 1-septate, slightly constricted at the septum, hyaline, smooth-walled. Asexual morph: Undetermined.

Type species - Phragmeriella ireninae Hansf.

Notes - Phragmeriella was introduced as a new genus in Sphaeriaceae by Hansford (1946) and is presently monotypic based on P. ireninae. von Arx and Müller (1975) transferred the genus to Dimeriaceae as it is parasitic on other fungi, has bitunicate asci and septate, hyaline ascospores. Lumbsch \& Huhndorf (2010) included Phragmeriella in the family Pseudoperisporiaceae. The genus is characterized by it mycoparasitic habit, transparent to light brown ascomata, with colourless stiff setae, unitunicate asci and septate, hyaline ascospores. The ascus layer appears to be unitunicate. The genus is therefore assigned to Sordariomycetes genera, incertae sedis. The placement of Phragmeriella is uncertain. It may be related to the family Niessliaceae (Hypocreales). New collections with sequence data is needed to confirm its placement.

Phragmeriella ireninae Hansf. Mycol. Pap. 15: 89 (1946)

Index Fungorum number: IF289468; Facesoffungi number: FoF03722

Fig. 111

Parasitic or hyperparasitic, fungicolous on mycelium of Irenina tremae Speg. (Meliolaceae), on living leaves of Tremae guineensis, superficial mycelium, branched and coloured. Sexual morph: Ascomata 58-87 $\mu \mathrm{m}$ diameter $\times$ 64-92 $\mu \mathrm{m}$ high, superficially, grouped, globose to subglobose, seated on mycelium of another fungus, transparent to light brown, texture soft, surrounded by colourless setae, aseptate, 31-42 $\mu \mathrm{m}$ long $\times$ 5-7 $\mu \mathrm{m}$ wide, collapsing when dry. Peridium 3-5 $\mu \mathrm{m}$ wide, comprising 1-2 layers of light brown cells of textura angularis, lacking pseudoparaphyses. Asci 29-41 × 7.5-14 $\mathrm{m}(\bar{x}=37 \times 12 \mu \mathrm{m}, \mathrm{n}=15), 8$-spored, unitunicate, oblong-subclavate, sessile, apex flattened. Ascospores $10-15 \times 3-5 \mu \mathrm{m}(\bar{x}=12 \times 4 \mu \mathrm{m}, \mathrm{n}=15), 1-$ 2-seriate, ellipsoid to obovate-oblong, ends rounded, 1-septate, slightly constricted at the septum, hyaline, smooth-walled. Asexual morph: Undetermined.

Material examined - UGANDA, Kiagwe Rifle Range, on mycelium of Irenina tremae Speg. (Meliolaceae), on living leaves of Trema guineensis (Schumach. \& Thonn.) Ficalho (Ulmaceae), May 1904, G.C. Hansford No. 2695 (IMI 1706, holotype).

\section{Doubtful genera}

Keratosphaera H.B.P. Upadhyay, Publicações Inst. Micol. Recife 402: 5 (1964)

Hyperparasitic, foliicolous on lichens, on Mazosia phyllosema (Nyl) A. Zahlbra, on living leaves. Colonies occurring on thallus of Mazosia, superficial, irregularly, scattered as black dots, lacking superficial mycelium. Sexual morph: Ascomata erumpent to superficial, solitary, scattered, globose, brown to black, with black setae, unbranched, tapering towards the apex, base wider. Asci 6-8-spored, bitunicate, ellipsoid to obclavate, subsessile, with paraphyses. Ascospores 1-2-seriate, oblique, clavulate, obtuse, 2-3-septate, hyaline, smooth-walled. Asexual morph: Undetermined.

Type species - Keratosphaera batistae H.B.P. Upadhyay 


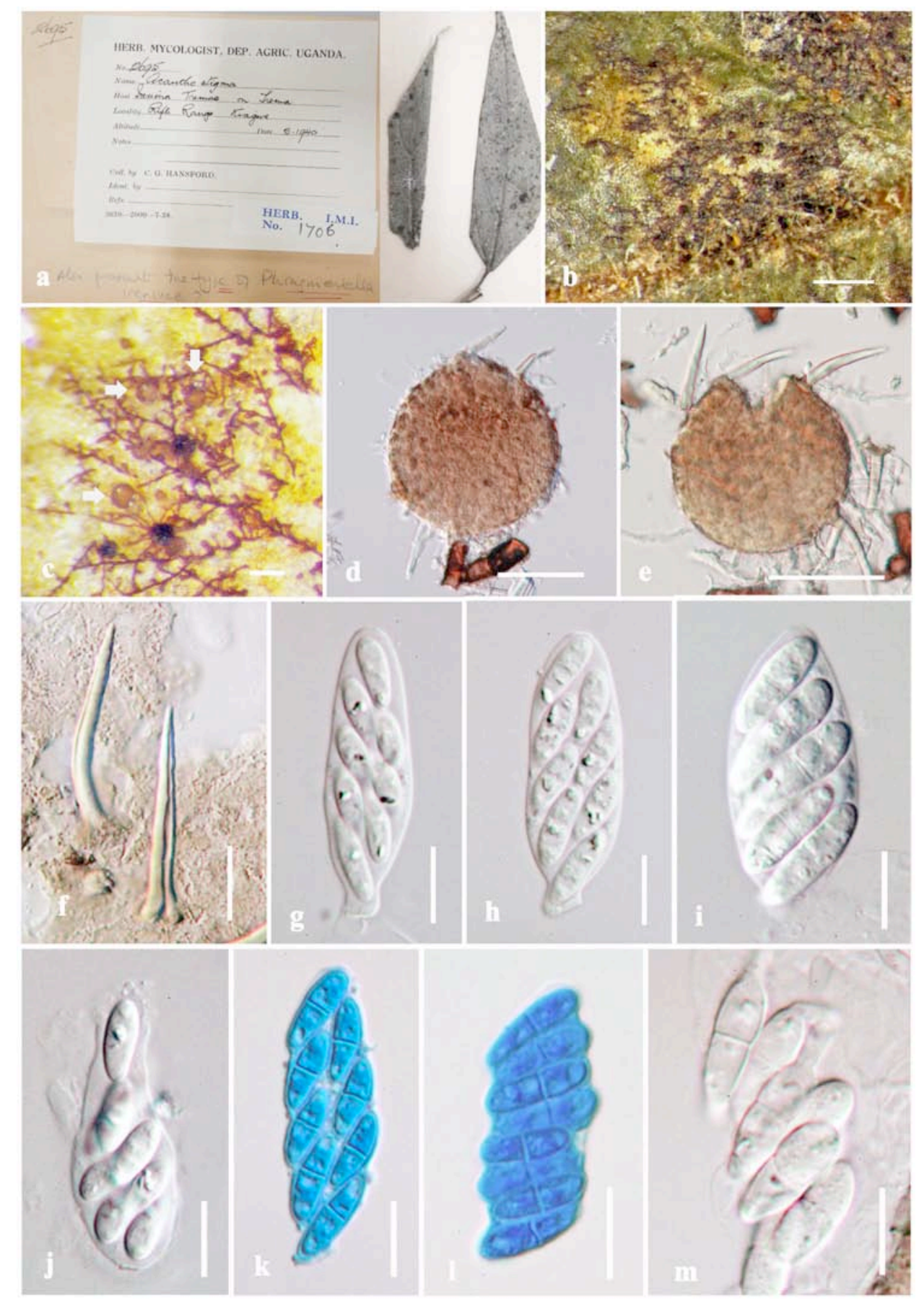

Figure 111 - Phragmeriella ireninae (IMI 1706, holotype). a Herbarium specimen and habit on leaves. b Dark colony of Meliolaceae. c Appearance of ascomata on mycelia of Meliolaceae on leaf surface, marked by arrows. d, e Squash mount of ascomata. f Setae. g-i Asci. j Broken ascus (unitunicate-like). k-m Ascospores. Note Figs k and 1 are stained in lactophenol-cotton blue. Scale bars: $\mathrm{b}=500 \mu \mathrm{m}, \mathrm{c}=100 \mu \mathrm{m}, \mathrm{d}, \mathrm{e}=50 \mu \mathrm{m}, \mathrm{f}-\mathrm{m}=10 \mu \mathrm{m}$.

Notes - The genus Keratosphaera was introduced Upadhyay (1964) to accommodate a hyperparasitic fungus associated with lichens which is typified by K. batistae H.B.P. Upadhyay. We were unable to locate the type specimens of Keratosphaera batistae and thus provide a description and illustration based on the protologue of Upadhyay (1964) to represent the genus. The genus Keratosphaera is characterized by black colonies with superficial, globose, pigmented, setose ascomata, bitunicate asci and hyaline, septate ascospores. However, detailed morphology is unclear, we therefore treated Keratosphaera as doubtful genus until new collections with sequence data become available. 
Keratosphaera batistae H.B.P. Upadhyay, Publicações Inst. Micol. Recife 402: 6 (1964)

Index Fungorum number: IF332732; Facesoffungi number: FoF03710

Fig. 112

Hyperparasitic, foliicolous on lichens, on Mazosia phyllosema ( $\mathrm{Nyl}$ ) A. Zahlbra, on living leaves of Orbignya martiana B. Rode. Colonies $0.8-1.5 \mathrm{~mm}$ diameter, occurring on thallus of Mazosia, superficial, irregularly, scattered as black dots, lacking superficial mycelium. Sexual morph: Ascomata 55-66 $\mu \mathrm{m}$ diameter, erumpent to superficial, solitary, scattered, globose, brown to black, with black setae, 9-15 $\mu \mathrm{m}$ long $\times 3-4.5 \mu \mathrm{m}$ wide, unbranched, tapering towards the apex, base wider. Asci 15-22 × 6.5-9 $\mu \mathrm{m}, 6-8$-spored, bitunicate, ellipsoid to obclavate, subsessile, with paraphyses. Ascospores 6-10 × 2-2.5 $\mu \mathrm{m}, 1$-2-seriate, oblique, clavulate, obtuse, 2-3-septate, hyaline, smooth-walled (Upadhyay 1964). Asexual morph: Undetermined.

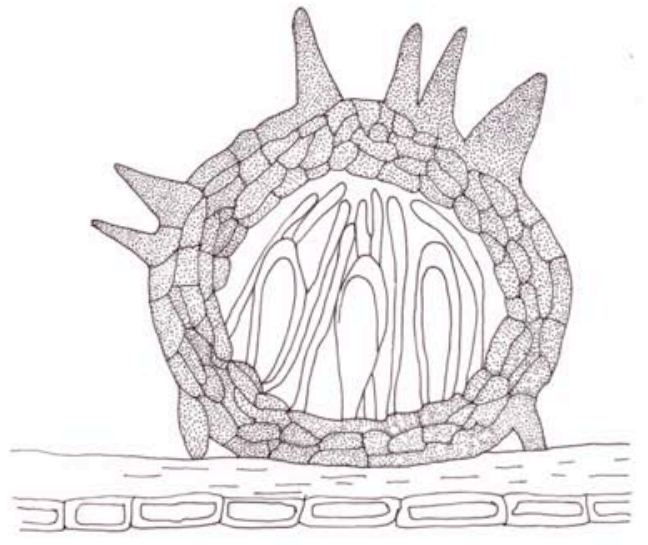

a

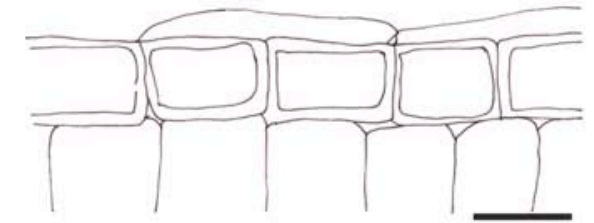

b

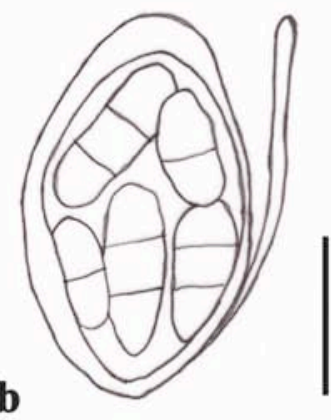

d

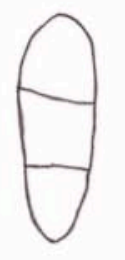

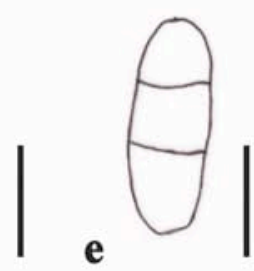

c
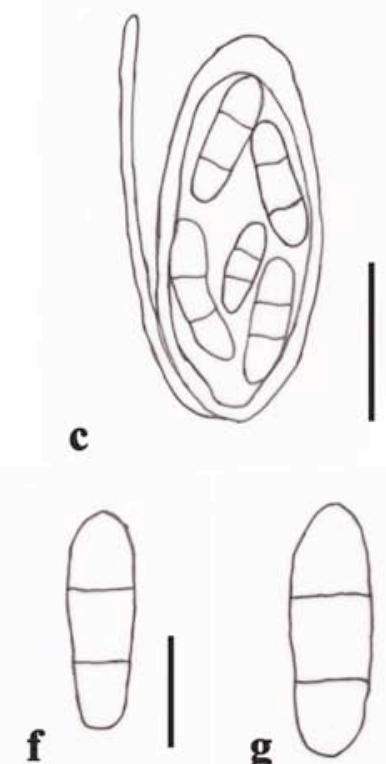

Figure 112 - Keratosphaera batistae (redrawn from Upadhyay 1964, Fig. 1a). a Ascoma. b, c Asci with cellular pseudoparaphyses. $d-g$ Ascospores. Scale bars: $a-c=10 \mu \mathrm{m}, d-g=5 \mu \mathrm{m}$.

Raciborskiomyces Siemaszko, Acta Soc. Bot. Pol. 2: 270 (1925)

Saprobic on living and dead leaves. Sexual morph: Ascomata superficial, sphaerical, globose to subglobose, solitary to grouped, surrounded by stiff setae, dark brown and acute at the apex, with sparse basal hyphae, with apical ostiole. Peridium comprising brown cells of textura angularis. Hamathecium comprising cylindrical filiform, branched, septate, anastomosed, hyaline, pseudoparaphyses. Asci 8-spored, bitunicate, cylindric-clavate, sessile or with short pedicel apex rounded, narrow towards the base, with filiform paraphyses. Ascospores 2-seriate, ellipsoidal, upper cell often distinctly wider than the lower cell, 1-septate, slightly constricted at the septum, hyaline when immature, becoming greyish to olivaceous brown when mature (from Nüesch 1960). Asexual morph: Undetermined.

Type species - Raciborskiomyces longisetosus (Volkart) M.E. Barr

Notes - The genus Raciborskiomyces was introduced by Siemaszko (1925) and is typified by R. polonicus. Siemaszko (1925) included this genus in the family Capnodiaceae based on its superficial mycelium and stiff setae. Raciborskiomyces was synonymized with Epipolaeum, and other genera and placed in various families including Sphaeriaceae, Venturiaceae and Dimeriaceae (Clements \& Shear 1931, Hansford 1946, Nüesch 1960, Müller \& von Arx 1962). Barr (1997) did not synonymise Raciborskiomyces under Epipolaeum and recognised Raciborskiomyces longisetosus as the type species based on the earlier name and synonymised $R$. polonicus. The genus is characterized by superficial, sphaerical, darkly pigmented ascomata, with dark stiff setae, bitunicate asci, and ellipsoidal, pigmented and uniseptate ascospores. We were unable to examine 
specimens of Raciborskiomyces polonicus and $R$. longisetosus and thus provide a description and illustration of $R$. longisetosus based on Nüesch (1960). Detailed morphology is unclear, we therefore treated Raciborskiomyces as doubtful genus until new collections with sequence data become available.

Raciborskiomyces longisetosus (Volkart) M.E. Barr, Mycotaxon 64: 165 (1997)

$\equiv$ Venturia longisetosa Volkart, in Rübel 1912

= Raciborskiomyces polonicus Siemaszko, Acta Soc. Bot. Pol. 2(4): 270 (1925)

$=$ Chaetyllis polonica (Siemaszko) Clem. \& Shear 1931

= Epipolaeum longisetosum (Volkart) Nüesch 1960

Index Fungorum number: IF437802; Facesoffungi number: FoF03711

Fig. 113

Saprobic on living and dead leaves of Salix sp. Sexual morph: Ascomata 50-90 $\mu \mathrm{m}$ diameter, superficial, sphaerical, globose to subglobose, solitary to grouped, surrounded by stiff setae, up to $200 \mu \mathrm{m}$ long and 4-9 $\mu \mathrm{m}$ thick, dark brown and acute at the apex, with sparse basal hyphae, with apical ostiole. Peridium comprising 1-3 layers of brown cells of textura angularis. Hamathecium comprising cylindrical, filiform, branched, septate, anastomosed, hyaline pseudoparaphyses. Asci 35-50 × 9-13 $\mu \mathrm{m}, 8$-spored, bitunicate, cylindric-clavate, sessile or with short pedicel, apex rounded, narrow towards the base, with filiform paraphyses. Ascospores 11-12.5(-15) $\times 4-5(-6)$ $\mu \mathrm{m}$, bi-seriate, ellipsoidal, upper cell often distinctly wider than the lower cell, 1-septate, slightly constricted at the septum, hyaline when immature, becoming greyish to olivaceous brown when mature (from Nüesch 1960). Asexual morph: Undetermined.

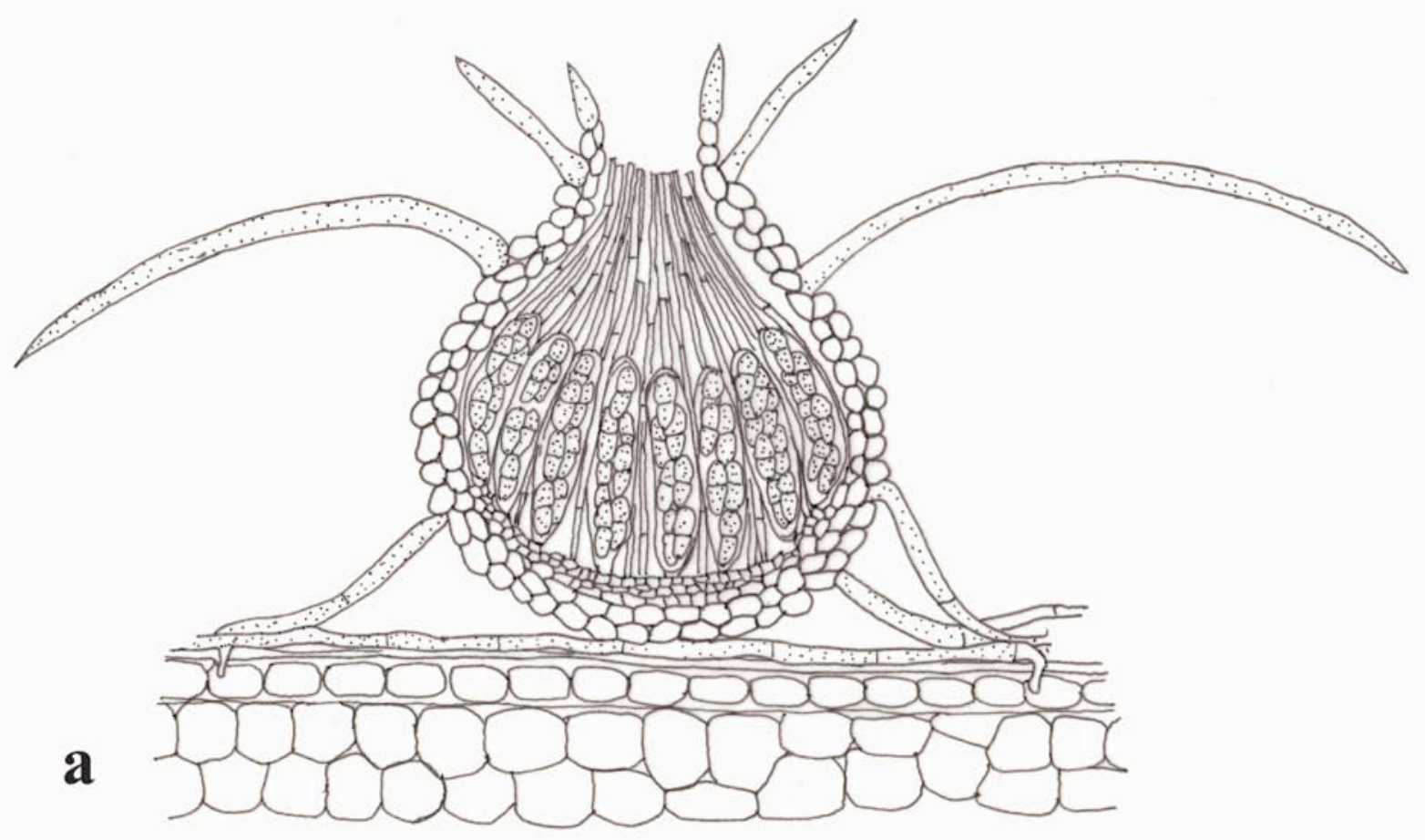

Figure 113 - Raciborskiomyces longisetosus (redrawn from Nüesch 1960, Fig. 11 under the name Epipolaeum longisetosum). a Ascoma have stiff setae, a hamathecium of pseudoparaphyses, and asci and ascospores.

\section{Acknowledgements}

S. Boonmee would like to thank the National Research Council of Thailand (No. 60215020003) and the Thailand Research Fund (No. TRG5880152). K.D. Hyde would like to thank Molecular Biology Experimental Center for the help on molecular work, the Mushroom Research Foundation (MRF), Chiang Rai, Thailand, the Thailand Research Fund grant no 
RSA5980068 entitled Biodiversity, phylogeny and role of fungal endophytes on above parts of Rhizophora apiculata and Nypa fruticans. R. Phookamsak expresses appreciation to The CAS President's International Fellowship for Postdoctoral Researchers, project number 2017PB0072, the Research Fund from China Postdoctoral Science Foundation (grant no. Y71B283261) and Chiang Mai University for financial support.

\section{References}

Acharius E. 1809 - Förteckning pa de i Sverige växande arter af Lafvarnes famille. Kongliga Vetenskaps Academiens Nya Handlingar 30, 97-102.

Alstrup V, Hawksworth DL. 1990 - The lichenicolous fungi of Greenland. Meddelelser om Grønland Biosciences 31, 1-90.

Ariyawansa HA, Hawksworth DL, Hyde KD, Jones EBG et al. 2014 - Epitypification and neotypification: guidelines with appropriate and inappropriate examples. Fungal Diversity 69, $57-91$.

Ariyawansa HA, Hyde KD, Jayasiri SC, Buyck B et al. 2015 - Fungal diversity notes 111-252taxonomic and phylogenetic contributions to fungal taxa. Fungal Diversity 75, 27-274.

Arnaud G. 1918 - Les Astérinées. Annales de l'École Nationale d'Agriculture de Montpellier 16, 1288.

Arnaud G. 1923 - Les Astérinées: III. Étude sur les champignons parasites (Parodiellinacées, suite). Annales des Épiphyties 9, 1-40.

Arnaud G. 1925 - Les Asterinees. IVe Partie. (Études sur la Systématique des champignons Pyrénomycetes). Annales Des Sciences Naturelles. Botanique 7, 643-723.

Barr ME. 1968 - The Venturiaceae in North America. Canadian Journal of Botany 46, 799-864.

Barr ME. 1979 - A classification of Loculoascomycetes. Mycologia 71, 935-957.

Barr ME. 1987 - Prodomus to class Loculoascomycetes. Published by the author, Amherst.

Barr ME. 1997 - Notes on some 'dimeriaceous' fungi. Mycotaxon 64, 149-171.

Barr ME. 2009 - A nomenclator of Loculoascomycetous fungi from the Pacific Northwest. North American Fungi 4, 1-94.

Batista AC. 1959 - Monografia dos fungos Micropeltaceae. Publicações do Instituto de Micologia da Universidade do Recife 56, 1-519.

Batista AC, Maia HS da. 1960 - Algumas espécies de Dimerina, Dimerium e Phaeodimeriella, assinaladas como hiperparasitas. Atas do Instituto de Micologia. Universidade de Pernambuco, Recife 1, 337-347.

Batista AC, Silva AA, Bezerra JL. 1965 - Balladynocallia n. gen. e outros Meliolaceae. Atas do Instituto de Micologia da Universidade do Recife 2, 215-243.

Batista AC, Peres GEP, Poroca DJM, Bezerra JL. 1967 - Três interessantes Ascomycotina de peritêcios setosos. Atas do Instituto de Micologia da Universidade do Recife 5, 235-243.

Batzer JC, Gleason ML, Harrington TC, Tiffany LH. 2005 - Expansion of the sooty blotch and flyspeck complex on apples based on analysis of ribosomal DNA gene sequences and morphology. Mycologia 97, 1268-1286.

Batzer JC, Arias MMD, Harrington TC, Gleason ML. 2008 - Four species of Zygophiala (Schizothyriaceae, Capnodiales) are associated with the sooty blotch and flyspeck complex on apple. Mycologia 100, 246-258.

Berlese AN. 1894 - Icones Fungorum omnium hucusque cognitorum, ad usum Sylloges Saccardianae adcommodatae. Berlin, 243.

Buck WR. 2016 - Lizonia emperigonia, a bryophilous fungus new to North America from Québec. Carnets de Bryologie 15, 1-3.

Butin H. 1973 - Beitrag zur Ascomyceten Flora von Chile. Sydowia 27, 267-292.

Cesati V, De Notaris G. 1863 - Schema di classificazione degle sferiacei italici aschigeri piu' o meno appartenenti al genere Sphaeria nell'antico significato attribuitoglide Persono. Commentario della Società Crittogamologica Italiana 1, 177-420. 
Chomnunti P, Schoch CL, Aguirre-Hudson B, Ko Ko TW et al. 2011 - Capnodiaceae. Fungal Diversity 51, 103-134.

Chomnunti P, Hongsanan S, Aguirre-Hudson B, Tian Q et al. 2014 - The sooty moulds. Fungal Diversity $66,1-36$.

Clements FE. 1909 - The genera of Fungi. 1-227.

Clements FE, Shear CL. 1931 - Genera of Fungi. edn 2. i-vii, 1-496, 58 plates. USA, New York; H.W. Wilson Company.

Coste C. 2014 - Découverte dans l'Aude (Les Martys, Aude, France) de: Opegrapha reactiva (Alstrup et Hawksworth) Etayo et Diederich. Un champignon lichénicole non lichénisé très rare en France. Les Carnets natures 1, 1-2.

Crous PW, Schoch CL, Hyde KD, Wood AR et al. 2009 - Phylogenetic lineages in the Capnodiales. Studies in Mycology 64, 17-47.

Crous PW, Wingfield MJ, Le Roux JJ, Richardson DM et al. 2015 - Fungal Planet Description Sheets: 371-399. Persoonia 35, 264-327.

Desmazières JBHJ. 1849 - Dix-septième notice sur les plantes cryptogames récemment découvertes en France. Annales des Sciences Naturelles Botanique 11, 339-365.

Dai DQ, Phookamsak R, Wijayawardene NN, Li WJ et al. 2017 - Bambusicolous fungi. Fungal Divers 82, 1-105.

Dissanayake AJ, Jayawardena RS, Boonmee S, Thambugala KM et al. 2014 - The status of family Myriangiaceae (Dothideomycete). Phytotaxa 176, 219-237.

Dissanayake AJ, Phillips AJL, Li XH, Hyde KD. 2016 - Botryosphaeriaceae: Current status of genera and species. Mycosphere 7, 1001-1073.

Döbbeler P. 1978 - Moosbewohnende Ascomyceten I. Die pyrenocarpen, den Gametophyten besiedelnden Arten. Mitteilungen aus der Botanischen Staatssammlung München 14, 1-360.

Döbbeler P. 1995 - Myxophora tjibodensis spec. nov. (Dothideales), ein weiterer Symbiont der Blaualge Scytonema. - In: Farkas EÉ, Lücking R, Wirth V (eds), Scripta lichenologica lichenological papers dedicated to Antonin Vezda. Bibliotheca Lichenologica 58, 73-80.

Döbbeler P. 1997 - Biodiversity of bryophilous ascomycetes. Biodiversity \& Conservation 6, 721738.

Döbbeler P. 2003 - Ascomycetes on Dendroligotrichum (Musci). Nova Hedwigia 76, 1- 44.

Döbbeler P, Hertel H. 2013 - Bryophilous ascomycetes everywhere: Distribution maps of selected species on liverworts, mosses and Polytrichaceae. Herzogia 26, 361-404.

Durbin RD, Davis LH, Snyder WC, Baker KF. 1953 - The imperfect stage of Mycothyriella rubi, cause of flyspeck of apple. Phytopathology 43, 470-471.

Ellis JB, Everhart BM. 1900 - New species of fungi from various localities. Bulletin of the Torrey Botanical Club 27, 571-578.

Eriksson OE. 1981 - The families of bitunicate ascomycetes. Opera Botanica 60, 1-220

Eriksson OE. 1999 - Outline of Ascomycota (ed.) (1999). Myconet 3, 1-88.

Eriksson OE, Baral HO, Currah RS, Hansen K et al. 2001 - Outline of Ascomycota (eds). Myconet 7, 1-88.

Eriksson OE, Hawksworth DL. 1993 - Outline of the ascomycetes - 1993. Systema Ascomycetum $12,51-257$.

Ertz D, Miadlikowska J, Lutzoni F, Dessein S, et al. 2009 - Towards a new classification of the Arthoniales (Ascomycota) based on a three-gene phylogeny focussing on the genus Opegrapha. Mycological Research 113, 141-152.

Ertz D, Tehler A. 2011 - The phylogeny of Arthoniales (Pezizomycotina) inferred from nucLSU and RPB2 sequences. Fungal Diversity 49, 47-71.

Etayo J, Sancho LG. 2008 - Hongos liquenícolas del sur de Sudamérica, especialmente de Isla Navarino (Chile). Bibliotheca Lichenologica 98, 1-302.

Fabre JH 1879 - Essai sur les Sphériacées du Départment de Vaucluse. Annales des Sciences Naturelles Botanique series 6, 66-118. 
Farr ML. 1963 - The systematic position of some Dimeriella species and associated fungi on Pinaceae. Mycologia 55, 226-246.

Farr ML. 1965 - Dimeriella, Wentiomyces, Episphaerella, and Epipolaeum (Fungi: Pyrenomycetes). Taxon 14, 18-21.

Farr ML. 1979 - The didymosporous dimeriaceous fungi described on Asteraceae. Mycologia 71, 243-803,

Farr ML. 1984 - The didymosporous dimeriaceous fungi reported on leaves of Rubiaceae. Mycologia 76, 793-803.

Farr DF, Rossman AY. 2017 - Fungal Databases, U.S. National Fungus Collections, ARS, USDA. Retrieved July 4, 2017, from https://nt.ars-grin.gov/fungaldatabases/

Fries EM. 1829 - Systema Mycologicum 3, 1-260.

Frisch A, Thor G, Ertz D, Grube M. 2014 - The Arthonialean challenge: restructuring Arthoniaceae. Taxon 63, 727-744.

Gaillard A. 1892 - Contribution à l'étude des champignons inférieurs famille des Périsporiacées: le genre meliola: anatomie - morphologie systématique. Bulletin de la Société Mycologique de France 1-243.

Gao L, Zhang M, Zhao W, Hao L et al. 2014 - Molecular and morphological analysis reveals five new species of Zygophiala associated with flyspeck signs on plant hosts from China. PLoS ONE 9, e110717.

Gäumann EA, Dodge CW. 1928 - Comparative Morphology of Fungi 1-701.

Gäumann EA. 1964 - ie Pilze. Grundzüge ihrer Entwicklungsgeschichte und Morphologie. $2^{\text {nd }}$ edn. Birkhäuser Basel.

Gonzalez-Fragoso R, Ciferri R. 1925 - Hongos parasitos y saprofitos de la Republica Dominicana. 1a Serie. Boletín de la Real Sociedad Española de Historia Natural, Biologica 25, 356-368.

Guatimosim E, Schwartsburd PB, Barreto RW. 2014 - A new Inocyclus species (Parmulariaceae) on the neotropical fern Pleopeltis astrolepis. IMA Fungus 5, 51-55.

Guatimosim E, Firmino AL, Bezerra JZ, Pereira OL et al. 2015 - Towards a phylogenetic reappraisal of Parmulariaceae and Asterinaceae (Dothideomycetes). Persoonia 35, 230-241.

Gueidan C, Aptroot A, da Silva Cáceres ME, Hamid Badali H et al. 2014 - A reappraisal of orders and families within the subclass Chaetothyriomycetidae (Eurotiomycetes, Ascomycota). Mycological Progress 13, 1027-1039.

Hansford CG. 1945 - Contribution towards the fungus flora of Uganda. VII. New records and revisions. Proceedings of the Linnean Society London 157, 20-41.

Hansford CG. 1946 - The foliicolous Ascomycetes, their parasites and associated fungi. Mycological Papers 15, 1-240.

Hansford CG. 1954 - Australian fungi. II. New records and revisions. Proceedings of the Linnean Society of New South Wales 79, 97-141.

Hansford CG. 1957 - Tropical fungi. VIII. Sydowia 11, 44-69.

Hawksworth DL, Eriksson OE. 1986 - The names of accepted orders of ascomycetes. Systema Ascomycetum 5, 175-184.

Hawksworth DL, Kirk PM, Sutton BC, Pegler DN. 1995 - Ainsworth \& Bisby's Dictionary of the Fungi. $8^{\text {th }}$ edition. 616 pp. UK, Oxfordshire, Wallingford; CAB International.

Hennings PC. 1895 - Fungi goyazenses. Hedwigia 34, 88-116.

Hennings PC. 1900 - Fungi mattogrossensis a Dr. R. Pilger collecti 1899. Hedwigia Beiblätter 39, 134-139.

Hennings PC. 1904 - Fungi Amazonici a cl. Ernesto Ule collecti III. Hedwigia 43, 351-400.

Henssen A, Jahns HM. 1974 - Lichenes. Eine Einführung in die Flechtenkunde. Georg Thieme Verlag, Stuttgart.

Hoffmann N, Hafellner J. 2000 - Eine Revision der lichenicolen Arten der Sammelgattungen Guignardia und Physalospora (Ascomycotina). Bibliotheca Lichenologica 77, 1-181. 
Hongsanan S, Tian Q, Hyde KD, Chomnunti P. 2015 - Two new species of sooty moulds, Capnodium coffeicola and Conidiocarpus plumeriae in Capnodiaceae. Mycosphere 6, 814824.

Hughes SJ. 1993 - Meliolina and its excluded species. Mycological Papers 166, 1-125.

Hughes SJ, Seifert KA. 1998 - The hyhomycete genus Heterosporiopsis Petrak. Sydowia 50, 192199.

Hyde KD, Jones EBG, Liu JK, Ariyawansa HA et al. 2013 - Families of Dothideomycetes. Fungal Diversity 63, 1-313.

Hyde KD, Hongsanan S, Jeewon R, Bhat DJ et al. 2016 - Fungal diversity notes 367-491: taxonomic and phylogenetic contributions to fungal taxa. Fungal Diversity 80, 1-270.

Inácio CA, Cannon PF. 2008 - The genera of the Parmulariaceae. CBS biodiversity series vol 8. CBS Fungal Biodiversity Centre, Utrecht.

Index Fungorum. 2017 - http://www.indexfungorum.org/Names/Names.asp

Jaklitsch W, Scheuer Ch, Voglmayr H. 2002 - Notes on the genus Immotthia (Pleosporales, Ascomycetes), including some type studies, Österreichische Zeitschrift für Pilzkunde 11, 93106.

Jayasiri SC, Hyde KD, Ariyawansa HA, Bhat DJ et al. 2015 - The faces of fungi database: fungal names linked with morphology, phylogeny and human impacts. Fungal Diversity 74, 3-18.

Johnston PR, Park D. 2016 - Neocoleroa metrosideri sp. nov. (Sympoventuriaceae, Venturiales). Phytotaxa 253, 214-218.

Joseph S, Sinha GP. 2012 - A new corticolous Opegrapha (Opegraphaceae) species from India. Lichenologist 44, 371-372.

Kalchbrenner K, Cooke MC. 1880 - South African fungi. Grevillea 9, 17-34.

Kendrick B. 1979 - The Whole Fungus, the Sexual-Asexual Synthesis in Proceedings of the Second International Mycological Conference Held at the Environmental Sciences Centre of the University of Calgary, Kananaskis, Alberta, Canada. Ottawa, Canada. Vol. 1, Ottawa: National Museums of Canada.

Kirk PM, Cannon PF, David JC, Stalpers JA. 2001 - Ainsworth \& Bisby's dictionary of the fungi, 9th edn. CABI, Wallingford.

Kirk PM, Cannon PF, Minter DW, Stalpers JA. 2008 - Ainsworth \& Bisby's dictionary of the fungi, 10th edn. CABI, Wallingford.

Kirschner R, Araúz V, Herbst F, Hofmann TA et al. 2010 - A new species of Puttemansia (Pleosporales) and new records of further Ascomycota from Panama. Sydowia 62, 225-241.

Kirschstein W. 1939 - Über neue, seltene und kritische Ascomyceten und Fungi imperfecti. II. Annales Mycologici 37, 88-140.

Léveillé JH. 1846 - Descriptions des champignons de l'herbier du Muséum de Paris. Annales des Sciences Naturelles Botanique 5, 249-305.

Li WJ, Bhat JD, Hyde KD, Wang Y. 2014 - Towards a natural classification of Dothideomycetes 4: The genera Bryopelta, Bryorella, Bryosphaeria, Lophiosphaerella and Maireella (Dothideomycetes incertae sedis). Phytotaxa 176, 28-41.

Liu JK, Hyde KD, Jones EBG, Ariyawansa HA et al. 2015 - Fungal diversity notes 1-110: taxonomic and phylogenetic contributions to fungal species. Fungal Diversity 72, 1-197.

Liu JK, Hyde KD, Jeewon R, Phillips AJL et al. 2017 - Ranking higher taxa using divergence times: a case study in Dothideomycetes. Fungal Diversity 84, 75-99.

Lücking R, Hodkinson BP, Leavitt SD. 2017 - The 2016 classification of lichenized fungi in the Ascomycota and Basidiomycota-Approaching one thousand genera. The Bryologist 119, 361-416.

Lumbsch HT, Huhndorf S. 2007 - Outline of Ascomycota. Myconet 13, 1-99.

Lumbsch HT, Huhndorf SM. 2010 - Myconet Volume 14. Part one. Outline of Ascomycota 2009. Part Two. Notes on Ascomycete Systematics. Nos. 4751-5113. Fieldiana Life Earth Science $1,1-64$.

Luttrell ES. 1955 - The Ascostromatic Ascomycetes. Mycologia 47, 511-532. 
Luttrell ES. 1973 - Loculoascomycetes. In: Ainsworth GC, Sparrow FK, Sussman AS (eds) The fungi, an advanced treatise, a taxonomic review with keys: ascomycetes and fungi imperfecti. Academic, London 135-219.

Luttrell ES, Barr ME. 1978 - Additional species of Pododimeria (Loculoascomycetes). American Journal of Botany 65, 251-257.

Ma Y, Zhang R, Sun G, Zhu H et al. 2010 - A new species of Zygophiala associated with the flyspeck complex on apple from China. Mycological Progress 9, 151-155.

Mapook A, Boonmee S, Liu JK, Jones EBG et al. 2016 - Taxonomic and phylogenetic placement of Phaeodimeriella (Pseudoperisporiaceae, Pleosporales). Cryptogamie Mycologie 37, 1-20.

McAlpine D. 1903 - Australian Fungi, new or unrecorded. Proceeding of the Linnean Society of New South Wales 28, 94-103.

Moreau C, Moreau M. 1955 - Ascomycetes de Cote d'Ivoire 1. Chevalieropsis ctenotricha (Pat. Et Har.) Arnud. Revue Mycologia Supplement Col 20, 48-55.

Moreau F. 1953 - Les Champignons. Tome II. Systematique. Encyclopédie Mycologique 23, 9412120.

Muggia L, Kopun T, Ertz D. 2015 - Phylogenetic placement of the lichenicolous, anamorphic genus Lichenodiplis and its connection to Muellerella-like teleomorphs. Fungal Biology 119, $1115-1128$.

Muggia L, Fleischhacker A, Kopun T, Grube M. 2016 - Extremotolerant fungi from alpine rock lichens and their phylogenetic relationships. Fungal Diversity 76, 119-142.

Müller E. 1958 - Über zwei neue Ascomyceten auf Juniperus-Arten. Sydowia 12, 189-196.

Müller E. 1962 - Über die Ascomycetengattung Stuartella Fabre. Bericht der Schweizerischen Botanischen Gesellschaft 72, 118-122.

Müller E, von Arx JA. 1950 - Einige Aspekte zur Systematik pseudopharialer Ascomyceten. Berichte der Schweizerischen botanischen Gesellschaft 60, 329-397.

Müller E, von Arx JA. 1962 - Die Gattungen der didymosporen Pyrenomyceten. Beitr Kryptogamenflora Schweiz 11, 1-922 .

Nüesch J. 1960 - Beitrag zur Kenntnis der weidenbewohnenden Venturiaceae. Phytopathologische Zeitschrift 39, 329-360.

Pande A. 2008 - Ascomycetes of Peninsular India.

Patouillard NT, Hariot P. 1900 - Énumération des champignons récoltés par M.A. Chevalier au Sénégal et dans le Soudan occidental. Journal de Botanique (Morot) 14, 234-246.

Petrak F. 1924 - Mykologische Notizen. VII. Annales Mycologici 22, 1-182.

Petrak F. 1934 - Mykologische Beiträge zur Flora von Sibirien. II. Hedwigia 74, 30-78.

Petrak F. 1949 - Bimeris nov. gen., eine neue Gattung der Sphaeropsideen aus Ekuador. Sydowia 3, 251-255.

Petrak F. 1950 - Beiträge zur Pilzflora von Ekuador. Sydowia. 4, 450-587.

Petrak F. 1952 - Beiträge zur Pilzflora von Florida. Sydowia 6, 399-406.

Petrak F. 1953 - Über die Gattungen Leptomeliola v. Höhn., Meliolinopsis Beeli, Hyalomeliolina Stevens und Phaeophragmeriella Hansf. Sydowia 7, 350-353.

Petrak F. 1955 - Beiträge zur Pilzflora von Zentral- und Südamerika. Sydowia 9, 550-555.

Petrak F. 1959 - Über die Gattung Myxothecium Kunze. Sydowia 13, 37-40.

Petrak F, Ciferri R. 1932 - Fungi Dominicani. II. Annales Mycologici 30, 149-353.

Phookamsak R, Liu JK, McKenzie EHC, Manamgoda DS et al. 2014 - Revision of Phaeosphaeriaceae. Fungal Diversity 68, 159-238.

Phookamsak R, Boonmee S, Norphanphoun C, Wanasinghe DN et al. 2016 - Schizothyriaceae. Mycosphere 7, 154-189.

Pirozynski KA. 1977 - Notes on hyperparasitic Sphaeriales, Hypocreales and 'Hypocreoid Dothideales'. Kew Bulletin 31, 595-610.

Raciborski M. 1900 - Parasitische Algen und Pilze Java's. 2, 1-46. 
Raciborski M. 1909 - Parasitische und epiphytische Pilze Javas. Bulletin International de l'Academie des Sciences de Cracovie Classe des Sciences Mathematiques et Naturelles 3, 346-394.

Rehm H. 1899 - Ascomycetes Fuegiani a P. Dusén collecti. Bihang till Kungliga svenska Vetenskaps-Akademiens Handlingar 25, 3-21.

Reynolds DR, Gilbert GS. 2005 - Epifoliar fungi from Queensland, Australia. Australian Systematic Botany 18, 265-289.

Rossman AY. 1987 - The Tubeufiaceae and similar Loculoascomycetes. Mycological Papers 157, $1-71$.

Rossman AY, Crous PW, Hyde KD, Hawksworth DL et al. 2015 - Recommended names for pleomorphic genera in Dothideomycetes. IMA Fungus 6, 507-523.

Saccardo PA. 1891 - Supplementum Universale, Pars I. Agaricaceae-Laboulbeniaceae. Sylloge Fungorum 9, 1-1141.

Saccardo PA. 1928 - Sylloge fungorum omnium hucusque cognitorum. Vol. XXIV. Sectio II. Supplementum universale Pars X. Curante Alex Trotter 705-1438.

Saccardo PA, Sydow P. 1902 - Supplementum Universale, Pars V. Sylloge Fungorum 16, 1-1291.

Seifert K, Morgan-Jones G, Gams W, Kendrick B. 2011 - The genera of hyphomycetes. CBSKNAW Fungal Biodiversity Centre, Utrecht.

Siemaszko W. 1925 - Fungi polonici novi et rariores. Acta Societatis Botanicorum Poloniae 2, 269-279.

Silvério ML, Cavalcanti MAQ, Bezerra JL. 2011 - First record of Leptomeliola uvariae for South America. Mycotaxon 116, 1-5.

Sivanesan A. 1981 - Balladynopsis, Balladynocallia and Alina. Mycological Papers 146, 1-38.

Sivanesan A. 1984 - The bitunicate ascomycetes and their anamorphs. J. Cramer, Vaduz, p 701.

Sivanesan A. 1987 - Studies on the genera Dimeriellopsis, Hyalomeliolina and Nematostoma. Systema Ascomycetum 6, 201-212.

Spegazzini C. 1888 - Fungi Guarinitici. Pugillus II. Anales de la Sociedad Científica Argentina. 26, $5-74$.

Spegazzini C. 1908 - Fungi aliquot paulistani. Revista del Museo de La Plata 15, 7-48.

Spegazzini C. 1912 - Mycetes argentinenses (Series VI). Anales del Museo Nacional de Historia Natural Buenos Aires 23, 1-146.

Stenroos S, Laukka T, Huhtinen S, Döbbeler P et al. 2010 - Multiple origins of symbioses between ascomycetes and bryophytes suggested by a five-gene phylogeny. Cladistics 26, 281-300.

Stevens FL. 1917 - Porto Rican fungi, old and new. Transactions of the Illinois Academy of Science 10, 162-218.

Stevens FL. 1923 - Parasitic fungi from British Guiana and Trinidad. Illinois Biology Monographs $8,1-76$.

Stizenberger E. 1862 - Beitrag zur Flechtensystematik. Bericht über die Tätigkeit der St. Gallischen Naturwissenschaftlichen Gesellschaft 1861-1862, 124-182.

Swart HJ. 1982 - Australian leaf-inhabiting fungi. XII. Semifissispora gen. nov. on dead Eucalyptus leaves. Transactions of the British Mycological Society. 78, 259-264.

Swart HJ. 1988 - Australian leaf-inhabiting fungi XXIX. Some ascomycetes on Banksia. Transactions of the British Mycological Society 91, 453-465.

Sydow H. 1925 - Fungi in itinere costaricensi collecti. Pars prima. Annales Mycologici 23, 308429.

Sydow H. 1926 - Fungi in intinere costaricensi collecti, pars secunda. Annales Mycologici 24, 283-426.

Sydow H, Sydow P. 1912 - Fungi from the island of Palawan. Leaflets of Philippine Botany 5, $1533-1547$.

Sydow H, Sydow P. 1913 - Novae fungorum species - X. Annales Mycologici 11, 254-271.

Sydow H, Sydow P. 1914 - Zweiter Beitrag zur Kenntnis der parasitischen Pilzflora des nördlichen Japan. Annales Mycologici 12, 158-165. 
Sydow H, Sydow P. 1916 - Fungi amazonici a cl. E. Ule lecti. Annales Mycologici 14, 65-97.

Sydow H, Sydow P. 1917 - Beitrag zur Kenntniss der Pilzflora der Philippinen-Inseln. Annales Mycologici 15, 165-268.

Sydow H, Sydow P. 1939 - Fungi aequatorienses. Annales Mycologici 37, 275-438.

Teixeira MM, Moreno LF, Stielow BJ, Muszewska A et al. 2017 - Exploring the genomic diversity of black yeasts and relatives (Chaetothyriales, Ascomycota). Studies in Mycology 86, 1-28.

Thambugala KM, Wanasinghe DN, Phillips AJL, Camporesi E et al. 2017 - Mycosphere notes 150: Grass (Poaceae) inhabiting Dothideomycetes. Mycosphere 8, 697-796.

Thaung MM. 1976 - Some ascomycetes from Burma. Transactions of the British Mycological Society 67, 435-441.

Theissen F. 1912 - Fragmenta brasilica IV nebst Bemerkungen über einige andere Asterina-Arten. Annales Mycologici 10, 1-32.

Theissen F. 1916 - Beiträge zur Systematik der Ascomyzeten. Annales Mycologici 14, 401-439.

Theissen F, Sydow H. 1915 - Die Dothideales. Kritisch-systematische Originaluntersuchungen. Annales Mycologici 13, 147- 746.

Theissen F, Sydow H. 1917 - Synoptische Tafeln. Annales Mycologici 15, 389-491.

Tian Q, Chomnunti P, Bhat JD, Alias SA et al. 2014 - Towards a natural classification of Dothideomycetes 5: The genera Ascostratum, Chaetoscutula, Ceratocarpia, Cystocoleus and Colensoniella (Dothideomycetes incertae sedis). Phytotaxa 176, 42-54.

Tibpromma S, Hyde KD, Jeewon R, Maharachchikumbura SS et al. 2017 - Fungal diversity notes 491-602: taxonomic and phylogenetic contributions to fungal taxa. Fungal Diversity 83, 1261.

Toro RA. 1926 - Mycological notes. I. Journal of the Department of Agriculture of Porto Rico 10, $11-23$

Toro RA. 1927 - Fungi of Santo Domingo - I. Mycologia 19, 66-85.

Toro RA. 1939 - The nomenclatural status of the genus Dimeriella Speg. Journal of Agriculture of the University of Puerto Rico 23, 73-90.

Toro RA. 1952 - Study of the tropical American black-mildews. Journal of Agriculture of the University of Puerto Rico 36, 24-87.

Upadhyay HBP. 1964 - Three new hyperparasites for Mazosia phyllosema (Nyl.) A. Zahlbr. from Amazonas valley. Publicações do Instituto de Micologia da Universidade do Recife 402, 111.

von Arx JA. 1959 - Ein Beitrag zur Kenntnis der Fliegenfleckenpilze. Proceedings van de Koninklijke Nederlandse Akademie van Wetenschappen Section C 62, 333-340.

von Arx JA, Müller E. 1954 - Die Gattungen der amerosporen Pyrenomyceten. Beiträge zur Kryptogamenflora der Schweiz 11, 1-434.

von Arx JA, Müller E. 1975 - A re-evaluation of the bitunicate Ascomycetes with keys to families and genera. Studies in Mycology 19, 1-159.

von. Höhnel F. 1907 - Fragmente zur Mykologie: IV. Mitteilung (Nr. 156 bis 168). Sitzungsberichte der Kaiserlichen Akademie der Wissenschaften MathematischNaturwissenschaftliche Klasse, Abt. I 116, 615-647.

von Höhnel F. 1909 - Fragmente zur Mykologie: VII. Mitteilung (Nr. 289 bis 353). Sitzungsberichte der Kaiserlichen Akademie der Wissenschaften in Wien MathematischNaturwissenschaftliche Klasse, Abt. I 118, 813-904.

von Höhnel F. 1913 - Fragmente zur Mykologie, Nr. 802. Über Enchnosphaeria pinetorum Fuck. Sitzungsberichte der Kaiserlichen Akademie der Wissenschaften in Wien MathematischNaturwissenschaftliche Klasse 1, Abt. 122, 287-289.

von Höhnel F. 1919 - Fragmente zur Mykologie. XXIII Mitteilung, Nr. 1154 bis 1188. Sitzungsberichte der Kaiserlichen Akademie der Wissenschaften in Wien MathematischNaturwissenschaftliche Klasse, Abt I 128, 535-625. 
von Höhnel FXR. 1910 - Fragmente zur Mykologie (XII. Mitteilung, Nr. 574 bis 641). Sitzungsberichte der Kaiserlichen Akademie der Wissenschaften in Wien MathematischNaturwissenschaftliche Klasse, Abt I 119, 877-958.

von Höhnel FXR. 1917 - Über die Trichothyriaceen. Berichte der Deutschen Botanischen Gesellschaft 35, 411-416.

Wijayawardene NN, McKenzie EHC, Hyde KD. 2012 - Towards incorporating anamorphic fungi in a natural classification - checklist and notes for 2011. Mycosphere 3, 157-228.

Wijayawardene NN, Crous PW, Kirk PM, Hawksworth DL et al. 2014 - Naming and outline of Dothideomycetes - 2014 including proposals for the protection or suppression of generic names. Fungal Diversity 69, 1-55.

Wijayawardene NN, Hyde KD, Rajeshkumar KC, Hawksworth DL et al. 2017 - Notes for genera: Ascomycota. Fungal Diversity 86, 1-594.

Williamson SM, Sutton TB. 2000 - Sooty blotch and flyspeck of apple: etiology, biology, and control. Plant Disease. 84, 714-724

Yang H, Ariyawansa HA, Wu HX, Hyde KD. 2014 - The genus Leptoxyphium (Capnodiaceae) from China. Phytotaxa 176, 174-183.

Zhang Y, Crous PW, Schoch CL, Bahkali AH et al. 2011 - A molecular, morphological and ecological re-appraisal of Venturiales a new order of Dothideomycetes. Fungal Diversity 51, 249-277. 